Universidade de São Paulo

Faculdade de Filosofia, Letras e Ciências Humanas

Departamento de Filosofia

\title{
ESTÉTICA E HERMENÊUTICA: A ARTE COMO DECLARAÇÃO DE VERDADE EM GADAMER
}

\author{
Almir Ferreira da Silva Júnior
}

Tese de Doutorado apresentada ao Departamento de Filosofia da Faculdade de Filosofia, Letras e Ciências Humanas da Universidade de São Paulo, sob a orientação do Professor Doutor Victor Knoll

São Paulo

2005 


\section{ESTÉTICA E HERMENÊUTICA: A ARTE COMO DECLARAÇÃO DE VERDADE EM GADAMER}

Almir Ferreira da S. Junior

"Neste momento de nossa história, o significado filosófico da arte reside principalmente na circunstância de que são as ciências, sobretudo as ciências naturais, as que determinam o modo de pensar da filosofia. Assim, cada recordação da arte é um corretivo a esse caráter unilateral da orientação moderna do mundo"

"[...] a experiência da obra de arte não só é o desvelamento do oculto, mas, ao mesmo tempo, está realmente aí dentro. Está dentro como em um recolhimento. A obra de arte é uma declaração que não constitui nenhuma frase enunciativa, porém é o que mais diz. É como um mito, como uma lenda, precisamente porque tanto retém o que diz, como, por sua vez, o brinda"

Hans-Georg Gadamer 


\section{DEDICATÓRIA}

À Zezé, junto a quem usufruo o privilégio da amizade. Amizade, enquanto uma permuta, abertura para reconhecer o outro nos limites de sua diferença, disposição para escutá-lo, sem realizar às cegas o que ele quer, para acatá-lo sem cerimônia e para protegê-lo sem artifícios.

A você, que me relembrou de que a amizade é uma experiência de já pertencer, o meu reconhecimento e a minha eterna admiração. 


\section{AGRADECIMENTOS}

À minha família, pelo apoio e pela paciência.

Ao meu amigo Ibrahim Neto e sua família, com quem pude compartilhar uma experiência de apoio, amizade e grande afeto. saudade.

À Dona Diva (in memoriam), pelo seu carinho de mãe, que ficou na memória e na

Às minhas amigas Zezé e Sibele, pela paciência, pelos momentos de alegria e de festividades, pela verdadeira e intensa amizade.

Aos meus colegas do Departamento de Filosofia da Universidade Federal do Maranhão, pelo incentivo.

À minha amiga Iolanda Mesquita, pela sua credibilidade, pelo incentivo constante e por sua sincera amizade.

À minha amiga-filósofa Victória Diaz, minha primeira leitora de um texto-projeto sobre hermenêutica, pela disponibilidade carinhosa e por sua amizade.

À minha amiga Olilia, companheira de jornadas difíceis, por seu constante apoio, encorajamento e senso de humor.

Aos meus amigos Plínio Fontenele e Luís Inácio, pelas suas acolhidas em São Paulo e pelo constante incentivo.

Ao meu amigo Helder Machado, pela sua compreensão e simplicidade em acreditar nos bons resultados das coisas.

Aos meus amigos cearenses Emiliano, Ilana e Veira, pelo fortalecimento constante e por suas alegrias.

À professora Nelci Gonçalves e ao professor Roberto Markenson, que muito simpaticamente me encaminharam aos estudos da hermenêutica.

À Ivone e à Margarida, pelo apoio e a disponibilidade.

Ao amigo Flávio, pelo apoio e acolhimento.

Aos meus colegas do Grupo de Estética da USP, Oliver, Rejane, Sônia, Izilda, com quem aprendi na escuta e na interlocução, pelo apoio e incentivo sempre dispensados.

Ao meu revisor e amigo, Zeca, por nossas conversas, que muito me ensinaram, e por sua gentileza e presteza.

À professora Scarlet Marton pelo decisivo impulso inicial e pela sua especial atenção.

Ao professor Marco Aurélio Werle, pela sua constante disponibilidade, por suas sugestões e indicações, que muito contribuíram para a realização de minha pesquisa.

Ao professor Franklin Leopoldo e Silva, por sua participação bastante enriquecedora em meu exame de qualificação, com seus questionamentos e sugestões.

Ao professor Victor Knoll, por ter-me recebido como orientando, pela habilidade de sua orientação e pela interlocução promissora.

Ao amor-es-ti, um amor vilaça de ser; dedicação que protege, presença intensa que me fortalece, me alegra e me faz crescer.

A todos aqueles que, direta ou indiretamente, contribuíram para a realização dessa pesquisa. 
SUMÁRIO

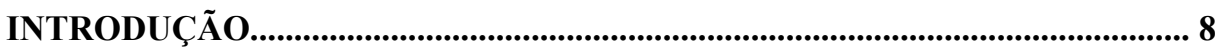

1. A ESTÉTICA NAS TRILHAS DA HERMENÊUTICA........................................................... 18

1.1 A relação entre hermenêutica e estética.................................................................... 18

1.2 A fundamentação da estética kantiana e a crítica da consciência estética........ 47

2. A EXPLICITAÇ̃̃o ONTOLÓGICO-HERMENÊUTICA DA ARTE...................................... 67

2.1 Sobre o conceito de experiência....................................................................................... 68

2.2 A experiência ontológica da arte........................................................................... 82

3. ARTE E HISTÓRIA: REFLEX̃̃ES HERMENÊUTICAS................................................... 101

3.1 A hermenêutica sob a vigilância da história............................................................ 103

3.1.1 O princípio de Wirkungsgeschichte e sua noção de consciência histórica..... 114

$3.2 \mathrm{O}$ caráter de atualidade da arte e sua experiência festiva..................................... 120

4. ARTE E LINGUAGEM: UMA RELAÇÃO HERMENÊUTICA................................................ 138

4.1 A arte sob a primazia da linguagem (Sprach): aproximações.............................. 138

5. ARTE E VERDADE: UM ACONTECIMENTO HERMENÊUTICO........................................... 161

5.1 A atualidade do Belo:a possibilidade de um diálogo entre Gadamer e Hegel..172

5.20 caráter paradigmático da tese hegeliana do fim da arte......................................180

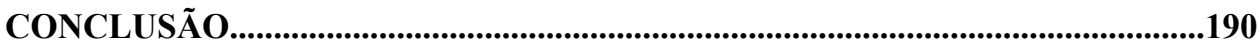

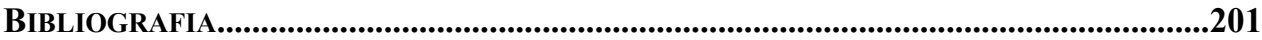




\title{
RESUMO
}

A pesquisa tem como objetivo investigar o que justifica o caráter paradigmático da análise sobre a questão da verdade da arte para a elaboração da hermenêutica filosófica de HansGeorg Gadamer em sua obra Verdade e método. A relação entre estética e hermenêutica, além de submeter o fenômeno estético a uma análise interpretativa, possibilita para a estética a recuperação do fenômeno da arte como experiência de verdade. A autonomia da reflexão sobre o domínio da estética e, especificamente, sobre o fenômeno da arte é garantida pelo propósito de uma análise crítica sobre o procedimento metodológico das ciências naturais. Para Gadamer, a pretensão exclusiva de demonstração de verdade baseada na verificabilidade de certezas é insuficiente para as ciências humanas. Examina-se a análise ontológicohermenêutica sobre a arte como condição de recuperá-la e reivindicá-la enquanto experiência de verdade. Analisa-se o caráter de subjetivação da estética, a partir da filosofia de Kant, como requisito fundamental para a retomada da questão da verdade a partir da arte. A tarefa hermenêutica da crítica à noção da consciência estética constitui-se como a abertura originária para se repensar a questão da verdade e sua relação com a arte. O que possibilita uma reflexão hermenêutica sobre a arte é sua análise ontológica tendo em vista a nova dimensão do compreender, segundo Heidegger, e o conceito de experiência a partir da dialética de Hegel. A experiência hermenêutica da arte é pensada como experiência ontológica de finitude, a partir das categorias de jogo, símbolo e festa, que, por sua vez, revelam o seu modo de ser. Identifica-se na estrutura de Verdade e método um intercâmbio entre os três domínios da experiência analisados: a arte, a história e a linguagem, o que possibilita à experiência da arte ser pensada a partir do princípio da história dos efeitos (Wirkungsgeschichte) e como determinação do fenômeno universal da lingüisticidade (Sprachlichkeit). Ressalta-se como elemento de análise o caráter declarativo da arte tendo em vista seu estatuto históricotemporal e interpretativo. A análise sobre a questão da verdade (aletheia) é articulada à explicitação ontológica sobre o caráter universal da linguagem (Sprach) e a crítica à pretensão de certeza apofântica da ciência. A partir do significado da arte como declaração (Aussage) examina-se a questão da atualidade da arte tendo também como parâmetro um diálogo entre Gadamer e Hegel, considerando a tese do caráter passado da arte (Vergangenheitslehre).

Palavras-chave: arte, verdade, ciência, história, hermenêutica

\begin{abstract}
This paper has the objective of investigating what justifies the paradigmatic character of the analysis on the questioning of truth for the elaboration of the philosophical hermeneutics by Hans-Georg Gadamer in his work Truth and Method (Continuum Impacts). The aesthetic and hermeneutic relationship not only submits the aesthetic phenomenon to an interpretive analysis but also does give the aesthetics the possibility of recovering the phenomenon of arts as an experience of truth. The autonomy of reflection upon the realm of aesthetics, and specifically on the phenomenon of arts is guaranteed by the purpose of a critical analysis on the methodological procedure of natural sciences. For Gadamer, the exclusive intention of demonstrating the truth based on the verification of certainties is insufficient for human sciences. The ontological-hermeneutic analysis on arts is examined as a condition to recover
\end{abstract}


and claim it as the experience of truth. The character of aesthetic subjectivity is analyzed, by Kant's philosophy, as a fundamental requisite to recover the questioning of truth from arts. The hermeneutic task of criticism on the notion of aesthetic consciousness constitutes the initial opening to rethink the questioning of truth and its relationship with the arts. What makes it possible to have a hermeneutic reflection upon the arts is its ontological analysis from the new dimension of understanding by Heidegger and from the concept of experience from Hegel's dialectics. hermeneutic experience The of arts is thought as an ontological experience of ending, from the categories of games, symbols and festivities that on their own reveal their way of being. In the structure of the work Truth and Method (Continuum Impacts) an interchange between the realms of experience analyzed (arts, history and language) is identified, what makes the experiencing of arts be considered from the principle of history of effects (Wikungsgeschichte) and from the universal phenomenon of linguistics (Sprachlichkeit). The declarative character of arts bearing in mind its historic-temporal and interpretative character is highlighted as an element of analysis. The analysis upon the questioning of truth (aletheia) is articulated to the ontological explicitness on the universal character of the language (Sprach) and the critical intention of the apophantical certainty of science. From the meaning of arts as a declaration (Auslegung) the questioning of the present arts is examined from a dialogue between Gadamer and Hegel, considering the thesis of the past character of arts (Vergangenheittslehre).

Key-words: arts, truth, science, history, hermeneutics 


\section{INTRODUÇÃO}

A hermenêutica não é apenas um conceito normativo que representa um lugar vazio a ser preenchido pela compreensão. Antes de tudo, é uma palavra portadora de significado e tradição, já que permanece na continuidade da memória. O termo "hermenêutica" advém da palavra grega hermeneia, que inicialmente significa expressão ou interpretação. Se não etimologicamente, ao menos simbolicamente, esse termo tem em sua origem a referência a Hermes, o deus mediador e mensageiro, aquele que transporta e traduz a mensagem dos deuses em uma linguagem acessível aos homens. É hermeneuein, uma exposição que ao ouvir uma mensagem a comunica. Ele ficou encarregado da técnica, a arte do hermeneutés, o intérprete que traduz numa linguagem inteligível. Hermes é o mensageiro dos deuses, mas também o encarregado dos limites e encruzilhadas de caminhos e de fronteiras. É um deus mediador, porque, estando entre as partes, põe-nas em comunicação. O lugar intermediário que ele ocupa garante a ele não a função de explicar, torna-o apenas revelador de uma mensagem ${ }^{1}$. Essa função de um deus da mediação torna a figura de Hermes essencialmente ligada à hermenêutica e, com ela, ao universo da interpretação. Entendida como arte ou ciência de interpretar textos, decifrando-os e trazendo-os à compreensão, a hermenêutica, seja do ponto de vista técnico ou mesmo do filosófico, sempre esteve voltada aos fenômenos do compreender e interpretar.

Em meados dos anos 80, afirma Gianni Vattimo, a hermenêutica tornou-se uma espécie de "topos koiné" da cultura ocidental ${ }^{2}$. Teoria que nasce para afirmar os direitos da interpretação do sentido, sua difusão e pluralidade aparecem na história do pensamento em várias versões, encaminhando-nos a diferentes autores. Se, em seus primórdios, ela esteve mais voltada a uma tecnologia que possibilitasse ou ainda auxiliasse discussões e interpretações textuais, até mesmo bíblicas e jurídicas, a história de seu desenvolvimento remete-nos para além de uma prática interpretativa. O que confere legitimidade a sua problemática é a necessidade de reconhecimento das expressões humanas enquanto componentes de sentido e significado. É a tentativa de torná-las objetivas pela intermediação subjetiva da interpretação que origina a especulação hermenêutica.

\footnotetext{
${ }^{1}$ Cf. Diccionario de hermenéutica, p. 252, 287, 295.

${ }^{2}$ Cf. G. VATTIMO, Para além da interpretação, p. 13.
} 
Remontando-nos à sua origem moderna, nos princípios do século XIX, além da generalização de métodos de interpretação, nela a discussão metodológica é originalmente submetida a uma abordagem de caráter epistemológico, em que se investigam, já na obra do pioneiro Friedrich Schleiermacher, os limites e possibilidades da compreensão. Seu propósito de indagar sobre as condições prévias a todo compreender permite a ela passar de um sistema de interpretação à metodologia das ciências humanas (Geisteswissenschaften).

Desse modo, foi então concebida como "arte da compreensão", doutrina da boa interpretação, técnica da boa interpretação. No tocante a seu caráter ilimitado de interpretações, ou mesmo ao modo pelo qual a hermenêutica propôs-se no universo da filosofia, da teologia e da literatura e do direito, sobressai um certo descrédito diante de afirmações tais como "ela é um mero instrumento", "apenas um apêndice da filosofia", "apenas uma retórica de convencimento", "um apelo à tradição, de caráter relativista"; conseqüentemente, carente de estrutura e métodos rigorosos que lhes garantam um caráter de cientificidade, tornara-se, por isso, uma obra da própria subjetividade.

A idéia hermenêutica circunscreve o horizonte do pensamento contemporâneo determinando-se em duas direções fundamentais. Por um lado, ela traduz um investimento de reflexão no universo da interpretação decorrente seja de uma atividade cognitiva, seja de uma atividade prática; por outro, remete-nos a compreender a linguagem como um modo privilegiado dessa nossa tarefa interpretante e enquanto atividade na qual nos determinamos como seres no mundo. A linguagem de modo algum pode estar dissociada da universalidade de nosso horizonte interpretativo ${ }^{3}$, por ser ela que articula nossa humanidade ao espaço da interpretação e compreensão dos fenômenos e acontecimentos.

Ainda que, inicialmente, sob uma perspectiva teórica, o problema da compreensão (verstehen) apresenta-se como núcleo central das discussões hermenêuticas, seja enquanto fundamento de uma teoria geral da interpretação, seja como metodologia das ciências humanas (Geisteswissenschaft). Ao propor a hermenêutica como metodologia geral das Geisteswissenschaft, Betti empenha-se em adquirir um conhecimento do processo de compreensão: a partir de nós, como podemos compreender a estrutura de significados criada

\footnotetext{
${ }^{3}$ A interpretação e a linguagem constituem-se como os dois caracteres fundamentais para a hermenêutica. A esse respeito, diz-nos Grondin: "Poder-se-ia, sem custo, subsumir todos os acontecimentos da filosofia de hoje sob esse duplo horizonte, mesmo que este permanecesse ignorado enquanto tal. Todas as discussões da ética aplicada, por exemplo, ainda quando elas debatem sobre casos ditos concretos, desdobram-se sob o fundo de uma universalidade de ordem interpretativa [...] Isto é, com efeito, a pluralidade moderna das opiniões sobre um assunto que nos incite a pesquisar os critérios, as normas, os consensos ad hoc, etc. A universalidade de ordem interpretativa pode, senão reanimar uma filosofia à vocação hermenêutica". Cf. J. GRONDIN, L'horizon herméneutique de la pensée temporaine, p. 7.
} 
pelos outros. Como este autor afirmava, desfrutamos de ansiedade em entender as formas significativas que intermedeiam nossa relação com os outros:

\begin{abstract}
"Nada é mais importante para o homem do que viver em compreensão mútua com seus semelhantes. Nada apela tanto para sua compreensão quanto os vestígios perdidos do homem que tornaram a vir à luz e lhes são dirigidos. Sempre que entramos em contato com as formas significativas (sinnhaltige Formen) por meio das quais uma outra mente se nos dirige, encontramos nossas capacidades interpretativas ansiosas por ficar a saber o sentido contido nessas formas. Do discurso efêmero aos documentos duradouros e restos silenciosos, da escrita aos chiffres e símbolos artísticos, da linguagem articulada à representação figurativa e musical [...] em suma, sempre que algo da mente de um Outro acerca-se de nós há um desafio à nossa capacidade de compreender proveniente da esperança da revelação",
\end{abstract}

Nossa capacidade intuitiva, uma vez orientada metodologicamente, deverá ter o discernimento daquilo que se representa para a aquisição de um conhecimento. Para Betti, se a interpretação apresenta-se como auxílio para resolver o problema da compreensão, trazendo algo a esta, a interpretação, por sua vez, só se torna possível em face das "formas significativas". São estruturas representativas que garantem um conhecimento relativamente objetivo, de acordo com critérios e diretrizes denominados cânones hermenêuticos, com vistas a garantir a autonomia, a coerência de sentido e a atualidade de uma interpretação.

Essa ênfase dada a diretrizes canônicas para interpretação aproxima ou mesmo nos encaminha nesse horizonte temático da hermenêutica à teoria de Friedrich Schleiermacher. Suas reflexões estão inseridas numa tradição exegética da teologia protestante vislumbrando um renascimento dos estudos da filologia clássica no final do século XVIII. Esse ideal, todavia, sobressai em seu caráter eminentemente filosófico, qual seja, o de analisar as condições sob as quais o fenômeno da compreensão ocorre, prescrevendo diretrizes para interpretá-lo. A busca de uma fundamentação sobre o conceito de compreensão associa-se exatamente ao problema epistemológico vigente no século XIX: como justificar metodologicamente as ciências humanas (Geisteswissenschaften) ${ }^{5}$ ? Com base em sua insatisfação quanto ao procedimento de interpretar e traduzir textos antigos clássicos, Schleiermacher propõe-se a elaborar uma hermenêutica geral (allgemeine Hermeneutik). A reflexão sobre o conjunto de regras e a explicação para realizar o procedimento interpretativo

\footnotetext{
4 E. BETTI, "A hermenêutica como metodologia geral das Geisteswissenschaft". In: J. BLEICHER, Hermenêutica contemporânea, p. 80.

${ }^{5}$ No propósito de estabelecer uma inteligibilidade própria às ciências humanas como reação à pretensão hegemônica das ciências naturais, a hermenêutica de Schleiermacher é reconhecidamente posta como base das ciências histórico-filológicas por Bockh e Droysen e por Dilthey, como fundamento das ciências humanas. Além disso, a hermenêutica contemporânea tem em Schleiermacher seu precursor, na medida em que o problema da compreensão mantém-se como núcleo fundamental da reflexão de pensadores hermeneutas, entre os quais, Heidegger, em Ser e tempo (Sein und Zeit), e Gadamer, em Verdade e método (Wahrheit und Methode).
} 
precisavam, agora, ser precedidas por uma investigação de cunho mais universal: quais as razões da arte do compreender? O que é interpretar? Desse modo, é a partir de Schleiermacher que na hermenêutica opera-se um deslocamento do domínio técnico-científico para o domínio filosófico. Em sua concepção preliminar, embora a hermenêutica possa ser definida como "arte da compreensão correta e do discurso de um outro", ela não se exerce apenas no domínio dos estudos clássicos - não se limita a ser um organon filológico, mas estende-se a quaisquer outros domínios em que haja a expressão do pensamento pelo discurso, bem como assume o propósito de compreensão não apenas do autor, e não apenas do texto enquanto texto. Ainda em seu caráter epistemológico e metodológico da compreensão a hermenêutica foi desenvolvida no início do século XX por Dilthey. No contexto de uma "crítica da razão histórica" busca desenvolver uma investigação transcendental sobre as condições de possibilidade do conhecimento histórico. Trata-se de recorrer à hermenêutica na tentativa de responder ao desafio imposto pelo conhecimento histórico quanto à conquista de sua legitimidade. Inserindo-se na problemática das ciências humanas do século XIX, Dilthey busca, mediante a análise do fenômeno verstehen, um modo de conhecimento adequado a experiência da vida.

A partir de então, o pensamento hermenêutico torna-se uma abordagem críticoreflexiva central na filosofia das ciências humanas, na filosofia da linguagem, na crítica literária e também na filosofia da arte. Aqui, no entanto, nos concentraremos na particularidade filosófica da hermenêutica de Hans-Georg Gadamer $^{7}$, ou melhor, naquela filosofia que se desenvolve ao redor do eixo Heidegger-Gadamer e cujo diferencial é a ruptura com uma hermenêutica de caráter essencialmente metodológico e o questionamento do princípio da subjetividade moderna como fundamento para explicar o fenômeno da compreensão e interpretação humanas.

$\mathrm{Na}$ perspectiva de uma hermenêutica de caráter essencialmente filosófico, o que a partir de então começa a ser considerado é um contexto de tradição ao qual sempre está ligado o ato de compreender e interpretar. Isso implica a radicalidade de uma existência prévia

\footnotetext{
${ }^{6}$ F. SCHLEIERMACHER, Hermenêtica, p. 67.

${ }^{7}$ Segundo Bleicher, três são as tendências da crítica hermenêutica contemporânea, resultantes dos diferentes modos de abordar o problema hermenêutico do significado das expressões humanas: a teoria hermenêutica como teoria geral das interpretações, ou metodologia das ciências humanas; a filosofia hermenêutica, crítica ao objetivismo e ao metodologismo, enquanto busca de um conhecimento fundamentado na explicação e descrição do "Dasein" humano, em sua temporalidade e historicidade; e a hermenêtica crítica, em seu desafio crítico aos considerados pressupostos idealistas, subjacentes tanto à filosofia hermenêutica, quanto à teoria hermenêutica. $\mathrm{O}$ pensamento de Gadamer, por sua vez, situa-se como uma expressão da filosofia hermenêutica, no horizonte da qual a obra deste filósofo empreende uma viragem lingüístico-filosófica (cf. J. BLEICHER, Hermenêutica contemporânea, p. 13-8).
} 
necessária à compreensão do objeto, predeterminando-o. A compreensão enquanto objeto de especulação hermenêutico transita do caráter eminentemente metodológico ao caráter ontológico, em que pese a relevante contribuição da filosofia fenomenológica, mediante seus questionamentos sobre a consciência e a noção de existência. Portanto, é sob a base ontológica da pergunta pelo sentido do ser que o problema hermenêutico da compreensão é redefinido, situando-se como possibilidade a retomada da problemática da autonomia das ciências humanas.

A hermenêutica, com suas longínquas ressonâncias, foi reivindicada no século XX mediante a renovação conferida à problemática filosófica da interpretação, entreaberta por Martim Heidegger. Sua consideração ultrapassa o âmbito da reclusão particular a que estava submetida, sendo então proposta como um problema universal e ontológico - logo filosófico -, e que por isso afeta todos os níveis de relação entre o homem e o mundo. Como ressalta Garagalza: "[...] esta transformação filosófica pode ser compreendida como um intento de dar resposta à crise ocorrida no começo do século XX pelas tradições que haviam alimentado o pensamento alemão pós-romântico, e em geral por toda a tradição ocidental, e que pode ser representada pelo fracasso da fenomenologia e o descrédito do neokantismo, assim como pela expansão de uma difusa atitude positivista e cientificista",

Ressalte-se aqui que uma das raízes ou mesmo estímulos teóricos que conduziram Gadamer a formular a proposta de uma hermenêutica filosófica foi a crítica à postura positivista que consistia em absolutizar um método de busca pela verdade. Para Gadamer, não seria esse o caminho que viabilizaria o alcance de uma fundamentação filosófica do conhecimento e do mundo, bem como do acesso à verdade. A compreensão e a interpretação, antes mesmo de serem conhecimento, são um modo de ser do homem vinculado a sua finitude. Eis o fundamento que prescreve a condição hermenêutica da existência humana, cuja finitude faz da compreensão uma tarefa infinita, universal, circular, no interior da qual não se dá nenhuma objetividade e nenhuma neutralidade de observação e interpretação, e, finalmente, nenhuma recaída no subjetivismo. A interpretação pertence agora a uma fusão de horizontes que acontece no cerne da linguagem. O medium da linguagem substitui o ser, e só em função dela alguém pode compreender os fenômenos do mundo.

Embora, na tradição do pensamento europeu, a palavra "hermenêutica" tenha vindo sempre seguida de um adjetivo, como, por exemplo, "literária", "jurídica" ou mesmo "bíblica", no cerne do pensamento contemporâneo, parece prevalecer a idéia de uma

\footnotetext{
${ }^{8}$ L. GARAGALZA, Introducción a la hermenéutica contemporánea, p. 10.
} 
autonomia de seu significado. Partindo-se do sentido a que alude o próprio termo, a teoria da interpretação, desde a Antiguidade, nunca se reduziu a simples teoria, já que sempre exigiu e promoveu, no âmbito de suas reflexões, uma práxis ${ }^{9}$, um elemento prático da atividade de compreender e interpretar. Como bem observa Gadamer, o fenômeno da compreensão e o modo correto de dar-se a interpretação sempre se constituíram como um problema hermenêutico. Mas, de posse da constatação de que outrora essa atividade referia-se à específica arte do anúncio, da tradução, da interpretação, à arte de compreender o sentido de algo quando este se mostra duvidoso ou obscuro, mediante a própria tarefa do hermeneus "[...] traduzir para uma linguagem acessível a todos o que se manifestou de modo estranho e incompreensível"10 -, verifica-se que ao longo de sua história ela assume competências normativas mais específicas.

Em seu caráter puramente pragmático-ocasional, a atividade da interpretação, nos tempos antigos, acabou por dirigir-se a campos e textos que ofereciam dificuldades de compreensão e, por conseguinte, para a própria práxis hermenêutica; entre eles, o campo da teologia e mesmo da jurisprudência. Entretanto, seu interesse filosófico amplia-se na medida em que começa a superar os âmbitos particulares - documentos religiosos, textos legais e clássicos de língua estrangeira -, bem como em decorrência de um distanciamento do conjunto da tradição histórica. Aos poucos, a hermenêutica deixa de especializar-se em campos e constrói-se como uma teoria geral da interpretação, ou uma reflexão crítica sobre a metodologia da compreensão. Ao cumprir a tarefa de interpretar, a hermenêutica visava, então, a afastar os eventuais erros de compreensão. Nesse ponto de vista, a interpretação tinha por fim a compreensão, de modo que interpretar significava buscar compreender. É precisamente esta perspectiva que, sendo aos poucos questionada, culmina na problemática hermenêutica da compreensão. $\mathrm{O}$ universo de sua abrangência, por sua vez, ultrapassa as regionalidades da interpretação, assume a estrutura da existência - especificamente a partir de Heidegger - e abarca os componentes significativos inerentes a toda experiência de mundo,

\footnotetext{
${ }^{9}$ Sobre a reflexão filosófica acerca do verdadeiro sentido de "práxis", Gadamer apresenta-nos "O que é práxis? As condições da razão social" (Was ist Práxis? Die Bedingungen gesellschaftlicher Vernunft, 1974). Sendo definida em oposição ao conceito de "teoria", o conceito de "práxis" assume, por vezes, uma conotação antidogmática, registrando um caráter de desconfiança do mero conhecimento teórico. Gadamer observa, no entanto, que nessa oposição tanto o conceito de teoria perde sua dignidade, quanto o conceito de práxis fica sujeito a limitações. A reflexão filosófica acerca da "práxis" não pode, pois, prescindir de sua base antropológica, bem como das transformações humanas e sociais daí decorrentes. Trata-se de uma escolha reflexiva, de uma prática a partir de antecipações, de um decidir-se a favor ou contra algo (Cf. H.-G. GADAMER, A razão na época da ciência, p. 41-56). As considerações acerca do significado conceitual sobre a "práxis" também são desenvolvidas em "Hermenêutica como filosofia prática" (Hermeneutik als praktische Philosophie).

${ }^{10}$ H.-G. GADAMER, $W M$, II, p. 92.
} 
no horizonte dos quais o ser humano determina-se e reconhece-se, até mesmo no domínio do belo e da arte.

Ressalte-se, todavia, que no final do século XIX a hermenêutica, ao ser compreendida como base das ciências humanas, mobiliza reflexões que sustentam a precariedade do seu pensamento, afirmando-a não se tratar de uma ciência considerando suas reflexões meramente estéticas e atividades de caráter literário ${ }^{11}$. No tocante a relação entre a hermenêutica e a estética isso acaba tendo ressonâncias significativas que por sua vez submeteriam o pensamento hermenêutico ao risco de cair num esteticismo.

Das diversas abordagens inerentes à estética, a discussão hermenêutica ocupa um lugar central, não apenas por submeter o fenômeno estético ao processo de interpretação, mas, sobretudo, porque essa reflexão mobiliza uma discussão sobre a relação entre modernidade e cultura estética, bem como confere ao fenômeno da arte, sua recuperação como experiência de verdade $^{12}$. Assim, situando-nos no cerne do pensamento filosófico de Gadamer, o objetivo de nossa pesquisa é analisar, a partir da especificidade da hermenêutica filosófica, o que justifica reivindicar ao fenômeno da arte uma declaração de verdade. Qual o real significado de retomada da pergunta pela verdade da arte como condição de possibilidade para a fundamentação da hermenêutica filosófica? O que torna a análise crítica sobre o domínio do estético um impulso reflexivo imediato para a estruturação do pensamento hermenêutico? Nesse percurso pretendemos mostrar que na condição de uma reconstrução de racionalidade a filosofia gadameriana constitui-se muito mais uma resposta à crítica da estetização da hermenêutica do que uma identificação com um esteticismo.

A reflexão sobre o domínio da estética e da arte apresenta uma legitimidade muito específica na obra fundamental de Gadamer, Verdade e método (Wahrheit und Methode), de 1960; seja pelo lugar que ocupa enquanto ponto de partida da referida obra, seja pelo significado paradigmático que esta assume enquanto experiência hermenêutica da verdade.

Nossas investigações sobre a experiência hermenêutica da arte concentram-se fundamentalmente na obra acima referida, bem como no texto, apresentado em conferência, que foi intitulado A atualidade do belo: A arte como jogo, simbolo e festa (Die Aktualität des Schönen. Kunst als Spiel, Symbol und Fest), de 1974. Isto, de certa forma, limita um pouco o

\footnotetext{
${ }^{11}$ C.f., J. GRONDIN, Hans-Georg Gadamer. Una biografia.p. 32

12 "Em sua versão standard, a hermenêutica significou para a estética a recuperação da atenção para com a arte como experiência de verdade, contradizendo uma tradição, consolidada na modernidade, geralmente indicada como kantiana e, sobretudo, neokantiana, que concebeu a estética como teoria da especificidade da experiência da arte [...]" (G. VATTIMO, Para além da interpretação, p. 93). Também nesse sentido e referindo-se ao binômio Estética e hermenêtica nos diz Pareyson em uma conversaçãao com S. Givone : " À base do pensamento hermenêutico existe, então, uma originária solidariedade nossa com a verdade" (Id.,Hermenêutica y racionalidad,p. 20)
} 
nosso exame, na medida em que estendemos poucas análises aos textos e ensaios propriamente estéticos que pertencem à fase posterior do pensamento de Gadamer, concentrados, sobretudo, no Volume 8 das Gesammelte Werke. Nosso ponto de partida consiste em identificar a especificidade da relação entre hermenêutica e estética; ou seja, caracterizar como ela verifica-se e quais suas perspectivas de tratamento no pensamento do hermeneuta. Inicialmente, o desenvolvimento desse propósito realizar-se-á de uma forma mais genérica, buscando esclarecer o que justifica a aproximação entre esses domínios de conteúdo - hermenêutica e estética -, e de que maneira o caráter de verdade inerente a sua experiência constitui seu horizonte investigativo nuclear. Posteriormente, nos concentraremos, sobretudo, em Verdade e método (Wahrheit und Methode), obra primordial e clássica de 1960, no propósito de compreender como aí se articula e se desenvolve a peculiaridade dessa relação sob a necessidade e o rigor de uma crítica ao subjetivismo estético.

Examinaremos de que modo a experiência vinculada ao conhecimento estético constitui-se como uma advertência paradigmática aos limites impostos pelo positivismo científico no tocante à busca da verdade. Num contexto em que a problemática de discussão refere-se ao processo de legitimidade epistemológica e à autonomia das ciências humanas (Geisteswissenschaften), de que modo o fenômeno artístico é tomado como referência de demonstração crítica ao subjetivismo moderno? Sob qual perspectiva de abordagem a renovação da pergunta pela arte implica uma ressignificação do conceito de experiência estética e uma restrição ao metodologismo científico como procedimento de objetivações e certezas? Como recuperar no horizonte de vivências estéticas e criações geniais uma referência que consigne à arte uma experiência de verdade e que, por sua vez justifique o mal entendido da arte ao render-se ao domínio da ciência, no tocante a questão da verdade?

Assim, em um segundo momento é sob a fundamentação da ontologia fundamental heideggeriana que não só a crítica ao subjetivismo moderno consolida-se, como também se estrutura a explicitação hermenêutica sobre o fenômeno da arte. A primazia dessa reflexão impõe como exigência pensar a arte em seu modo de ser, como um ser que vem à representação (Darstellung). É sob o rigor de uma reflexão ontológica que a hermenêutica resgata a possibilidade de repensar arte como experiência de verdade. Enquanto experiência da finitude, a arte é movimento lúdico, interativo, simbólico, porque sinal de reconhecimento e cuja presença temporal é pura celebração.

A identificação da estética nas trilhas da hermenêutica tem o seu desdobramento que a interliga à estrutura da obra Verdade e método. O que assegura a relação entre verdade e 
método tem como ponto de partida uma crítica à consciência estética, cujo resultado imediato é a possibilidade de pensar a arte considerando o horizonte de significação da experiência hermenêutica: a abertura, a historicidade, o diálogo e, sobretudo, a finitude. O conceito de experiência é nuclear na obra de Gadamer, de modo que a estrutura desta permite interligar os seus três níveis então abordados: a arte, a história (Wirkungsgeschichte) e a linguagem (Sprach). Isso dá a medida da necessidade de desenvolvermos e justificarmos a experiência da arte e sua relação com a história e, posteriormente, como experiência lingüística (Sprachlichkeit).

Na condição de uma hermenêutica da finitude, a hermenêutica filosófica de Gadamer é também histórica. Caracteriza-se, conceitualmente, o significado do princípio de história dos efeitos (Wirkungsgeschichte) como elemento imprescindível para analisarmos a questão da atualidade da arte, bem como de sua pretensa declaração de verdade. Ressaltaremos nesse propósito o argumento de reabilitação da tradição (Tradition) como horizonte fundamental para a compreensão. Tradição que também significa transmissão, testemunho imprescindível de que o passado interpela-nos quando se trata de compreendermos algo. A relação entre arte e história, conforme mostraremos, consolida-se porque, enquanto experiência de verdade, ela determina-se para ser uma fusão de horizontes garantindo sempre uma abertura à alteridade e às interpretações.

Posteriormente examinaremos o que poderia parecer bastante óbvio para uma proposta de pensar a relação entre estética e hermenêutica, isto é, a inevitabilidade de considerar o fenômeno da arte como uma experiência de linguagem. Ressaltaremos, no entanto, que o diferencial dessa abordagem dá-se tanto pelo caráter ontológico da definição da linguagem como abertura originária, condição prévia de toda compreensão, quanto pelo caráter de universalidade que a lingüisticidade (Sprachlichkeit) assume enquanto dimensão filosófica na hermenêutica gadameriana. A reflexão sobre a experiência da linguagem é a expressão máxima da análise hermenêutica, na medida em que aí também se verifica a sua conexão com a questão da verdade. Pensada em conformidade com o ser, a linguagem é abertura sob a forma de um movimento de desocultação, de verdade (aletheia). Em seu pronunciamento, a linguagem constitui-se como o medium que viabiliza a fusão de horizontes históricos, a intermediação entre eles. Sua reflexão amplia a questão da verdade como busca de sentido, como fazer vir-à-fala, independentemente de sua presença lingüística (Spraclichkeit). A arte é verdade enquanto um vir-à-fala, e, nesse modo de pôr-se enquanto presença, ela reivindica uma experiência de verdade que reduz a compreensão da verdade científica a uma particularidade. Além de uma reflexão ontológica por meio da qual reconheceremos a arte na 
esfera de sua lingüisticidade, desenvolveremos, ainda, uma articulação sobre a identidade arte e verdade, tendo em vista não somente uma consideração analítica sobre a noção de verdade enquanto aletheia, mas propondo um pequeno diálogo entre Gadamer e Hegel, a partir de Heidegger. É viabilizando uma aproximação entre as diferenças que a hermenêutica, ao pensar a arte como declaração de verdade, pode "construir pontes e transpor distâncias" 13 .

\footnotetext{
${ }^{13}$ J.HABERMAS, "Hans Georg Gadamer: Urbanização da província heideggeriana" in: Dialética e Hermenêutica, p. 74.
} 


\section{A ESTÉTICA NAS TRILHAS DA HERMENÊUTICA}

\subsection{A relação entre hermenêutica e estética}

Investigar a dimensão estética no legado filosófico de Gadamer significa, antes de tudo, perguntar pela importância e pelo lugar que esse domínio da experiência humana ocupa no conjunto de seu pensamento. De um modo geral, essas reflexões e questionamentos estão condensados em seus vários textos e ensaios estéticos ${ }^{14}$. No entanto, é precisamente em Estética e hermenêtica (Ästhetik und Hermeneutik) ${ }^{15}$, no conjunto de seus questionamentos e argumentações, que a abordagem dessa relação formula-se de modo bem objetivo. Com um título bastante genérico, aí, nos parece, está uma abertura de questões que fundamentam a possibilidade e necessidade de uma reflexão hermenêutica sobre a arte e que, de uma forma bem direta, remetem-se às reflexões que, inicialmente, articulam-se na importantíssima obra Verdade e método. Orientar-nos-emos pelas seguintes indagações:

- Do ponto de vista da abrangência conceitual da hermenêutica, como se constitui a abordagem do estético e também do fenômeno da arte?

- Qual a problemática central a partir da qual a relação estética e hermenêutica desenvolve-se?

Entre as tantas experiências que vivenciamos enquanto seres naturais e históricos, a arte constitui-se, diz Gadamer, como aquela "que nos fala algo de modo mais imediato [...] respira uma familiaridade enigmática que prende todo o nosso ser, como se não houvesse aí nenhuma distância e todo encontro com uma obra de arte significasse um encontro conosco mesmos"16. Essa formulação parece conter os elementos fundamentais característicos das reflexões estéticas gadamerianas. Em sua relação primordial, a exposição do fenômeno artístico determina-se por sua força declarativa. A arte é declaração (Aussage), e o fato de dizer-nos algo insere-a na ordem de tudo aquilo que temos de compreender. Desse modo, o

\footnotetext{
${ }^{14}$ Esses textos, Gadamer caracteriza-os como uma "pletora de pequenas conferências e ensaios" (eine Fülle kleinerer Reden und Aufsätze). Eles encontram-se reunidos no Volume 8 de suas Obras Reunidas (Gesammelte Werke, a que doravante faremos referência como "GW"), intitulado Arte como declaração (Kunst als Aussage). São assim denominados "pletora" porque, em sua totalidade, buscam responder a um determinado conjunto de questões.

${ }^{15}$ Conferência pronunciada no V Congresso de Estética, realizado em Amsterdã no ano de 1964.

${ }^{16}$ H.-G. GADAMER, Ästhetik und Hermeneutik, in: $G W, 8$, p. 1.
} 
que confere legitimidade à reflexão hermenêutica da arte é a possibilidade de pensá-la como experiência de mundo que o homem faz pela linguagem, revelando-se a si e aos outros, por meio do fenômeno da compreensão ${ }^{17}$.

A formulação algumas vezes repetida por Gadamer - a hermenêutica contém a estética $^{18}$ - implica que a hermenêtica busca articular uma interpretação sobre o fenômeno estético - seja ele uma experiência do belo na natureza ou na arte - tendo em vista o processo de mediação pelo qual a existência humana constrói sua própria experiência de mundo, integra-se e forma sua própria tradição. Neste âmbito, sobressai a presença declarativa da arte radicada no caráter permanentemente presente da obra, sua especial atualidade (Gegenwartigkeit). Como diz Gadamer: "Faz parte da experiência artística que a obra de arte sempre tenha seu próprio presente [...] que seja expressão de uma verdade que de modo algum coincida com a intenção de seu criador" ${ }^{\prime 19}$. Na qualidade de obra, a arte é uma declaração atualizada.

Nessas considerações sobre o fenômeno artístico destacam-se dois aspectos constitutivos da hermenêutica: o ontológico e o referente à linguagem (Sprachlich). Uma reflexão hermenêutica sobre o domínio da arte tem, pois, o propósito de pensá-la em sua essência, indagando sobre a especificidade de seu modo de ser, sobre aquilo que a constitui, ontologicamente, como experiência e linguagem. Sua inesgotável capacidade de expressão, sempre aberta a novas integrações da existência humana revela em seu ser uma presença que, no entanto, ultrapassa a limitação histórica (geschichtliche Beschränktheit). Por isso, enquanto expressão de verdade (Ausdruck einer Wahrheit), tal análise não se limita à simples busca do significado histórico-original de sua criação. Como esfera de realização humana, a arte é

\footnotetext{
${ }^{17}$ Tendo em vista a íntima relação da hermenêutica com a interpretação, aquela, desde sua origem, reuniu uma dupla tarefa: descobrir o conteúdo do significado exato seja de uma palavra, ou de um texto, etc.; e descobrir as instruções contidas em formas simbólicas. Na medida em que a explicação interpretativa buscava tornar transparentes os significados, o fenômeno da compreensão correta tornava-se um desafio. Em seu caráter teórico, metodológico ou mesmo filosófico, a hermenêutica sempre esteve comprometida com a análise do verstehen, daí suas diferentes concepções. Em Gadamer o fenômeno da compreensão tem, especificamente, o sentido daquilo que fora formulado por Heidegger em sua analítica da existência, o modo de ser do Dasein.

${ }^{18}$ A relação entre hermenêutica e estética, no modo pelo qual é desenvolvida pela hermenêutica de Gadamer, supõe, em nosso entender, alguns esclarecimentos, do ponto de vista do uso de suas terminologias. Os termos "arte" (ars) e "estética" (aisthesis) evidentemente não são sinônimos, embora a referência de um possa muitas vezes conduzir à especificidade do outro. É necessário afirmar que se, por um lado, Gadamer busca legitimar a necessidade de o fenômeno da arte ser tomado como objeto de especulação do pensamento hermenêutico, por outro, os fundamentos de uma hermenêutica filosófica não podem prescindir de uma discussão crítica com a estética enquanto um saber constituído a partir do pensamento moderno. É claro, todavia, que da análise crítica sobre a fundação e formação do saber estético, tendo em vista a gênese de sua consciência e a formação de sua cultura, Gadamer oferece-nos uma reflexão ontológico-hermenêutica sobre sua experiência.

${ }^{19}$ H.-G. GADAMER, Ästhetik und Hermeneutik, in: GW, 8, p. 1.
} 
experiência que ultrapassa o próprio tempo, o que lhe confere um caráter específico quanto a sua temporalidade.

Vale lembrar que, em sua determinação originária, a hermenêutica baseava-se em seu esforço de explicar e transmitir ao outro o que não era imediatamente compreensível. Daí ser seu fundamento a figura mítica de Hermes, o intérprete, tradutor e mensageiro da palavra divina aos homens. Após o romantismo alemão, sustenta Gadamer, sua tarefa ampliou-se no sentido de também evitar mal-entendidos (Mißverstand $z u$ vermeiden ${ }^{20}$, passando a corresponder, fundamentalmente, a um acontecimento lingüístico, cujo propósito é a compreensão das mais diversas manifestações lingüísticas em suas declarações de sentido. Conforme afirma Vattimo, se em Heidegger, mesmo ele dando posteriormente uma grande ênfase à linguagem, o problema da interpretação é desenvolvido, sobretudo, a partir do problema do ser; para Gadamer, a interpretação tem sua análise desenvolvida do ponto de vista da linguagem, apesar de toda a ênfase dada à ontologia ${ }^{21}$. Desse modo, torna-se compreensível que a questão nuclear em torno da qual Gadamer desenvolve essa relação temática hermenêutica e estética concentre-se, fundamentalmente, na dimensão interpretativa da obra de arte, tendo em vista o questionamento de seu sentido e a investigação de seu modo de ser. Se em sua realidade declarativa seu sentido não está, todavia, restrito à sua origem vital e espaciocultural, em que consistiria sua experiência?

É o próprio questionamento hermenêutico que vislumbra a compreensão da obra de arte como busca de sentido no horizonte do tempo e da história; sentido daquilo que ela nos diz enquanto "obras criadas por homens para homens",22.

Assim, sustenta Gadamer, a hermenêutica contém a estética, pois, enquanto um medium que diminui a distância entre os espíritos, revelando a cada um deles suas estranhezas, sua tarefa não se limita à reconstrução histórico-original do significado da obra de arte, mas incita-nos a perguntar pela sua linguagem (Sprach der Kunst), a escutar e compreender o que ela diz enquanto experiência particular de verdade. É a atualidade (Gegenwartigkeit) de sua presença, sua superioridade sobre o tempo (Zeitüberlegenheit), que a converte em linguagem repleta de sentido e específica experiência de verdade. Eis aí, segundo Gadamer, a problemática central que estimula a discussão hermenêutica da arte, bem

\footnotetext{
${ }^{20}$ Isso também se justifica mediante o despertar da consciência histórica, que advertiu quanto à possibilidade de nos enganarmos sobre a tradição, gerando, conseqüentemente, equívocos no processo de sua compreensão.

${ }^{21}$ Cf. G. VATTIMO, Para além da interpretação, p. 15.

${ }^{22}$ H.-G. GADAMER, Ästhetik und Hermeneutik, in: $G W, 8$, p. 3.
} 
como o desafio de compreender em que medida "todo encontro com a arte significa um encontro conosco mesmos ${ }^{\prime 23}$.

Do ponto de vista de uma abordagem mais geral, identificando-se as relações conceituais e questionamentos fundamentais, uma reflexão hermenêutica sobre a arte, além de não poder prescindir de uma leitura crítica acerca do processo de sua formação reflexiva - a estética -, reivindica como sua proposta fundamental o desafio de compreender sua experiência no horizonte de sua problemática com a verdade, da linguagem, da história. Pensar o fenômeno da arte segundo a especificidade de um fenômeno hermenêutico é, essencialmente, tomá-lo enquanto linguagem, presença histórica e declaração como acontecimento de verdade.

Passemos, em seguida, ao específico horizonte filosófico-argumentativo que define e sustenta a possibilidade da relação hermenêutica e estética no pensamento gadameriano. Nesse, as questões para as quais se acenou acima serão desenvolvidas na particularidade de seus argumentos, tendo em vista a estrutura de suas rememorações e interpretações junto à tradição do pensamento. Elucidá-lo significa tomar como referência a obra nuclear do pensamento filosófico de Gadamer, no interior de sua problemática ${ }^{24}$.

Verdade e método (Wahrheit und Methode), de 1960, é, reconhecidamente, a obra central da hermenêutica filosófica de Gadamer. Demarcados seus fins e propósitos - traços fundamentais de uma hermenêutica filosófica -, nela abre-se o cerne de sua convicção filosófica, bem como sua singularidade diante da tradição hermenêutica. Merece nossa especial atenção, todavia, o fato de a referida obra apresentar como primeira parte a "liberação da questão da verdade desde a experiência da arte". Assim sendo, formulamos as seguintes questões a serem desenvolvidas: o que justificaria uma reflexão sobre a arte como ponto de partida para apresentação e compreensão dos fundamentos de uma hermenêutica filosófica? Qual o alcance de uma análise sobre o fenômeno estético para a definição da hermenêutica filosófica de Gadamer? Em que medida o âmbito de abordagem a partir do qual a experiência da arte é pensada enquanto questão de verdade constitui a especificidade da relação entre estética e hermenêutica, no pensamento de Gadamer?

\footnotetext{
${ }^{23}$ H.-G. GADAMER, Ästhetik und Hermeneutik, in: GW, 8, p. 1.

${ }^{24}$ Originariamente o título da obra seria Compreender e acontecer, mas, dada a insatisfação por parte do editor, tendo em vista a proposta do subtítulo Fundamentos de uma hermenêutica filosófica, a obra vem a intitular-se, posteriormente, Verdade e Método: Fundamentos de uma hermenêutica filosófica. Torna-se ainda relevante destacarmos o caráter provocativo desse título, conforme ressalta Ernildo Stein. Segundo sua leitura, trata-se, de fato, da verdade contra o método, uma vez que Gadamer busca mostrar, em sua estrutura, que nas experiências da arte, da história e da linguagem é produzido um tipo de verdade incompatível com o método lógico-analítico (Cf. E. STEIN, Aproximações sobre hermenêutica, p. 44).
} 
Verdade e método apresenta como subtítulo o que de fato constitui seu grande propósito, ou seja, a formulação dos "fundamentos de uma hermenêutica filosófica". Mesmo, desde cedo, recebendo uma forte influência do filósofo alemão Martin Heidegger, tanto da fase inicial quanto da tardia de seu pensamento, a expressão utilizada por Gadamer não é "fenomenologia hermenêutica", mas sim "hermenêutica filosófica".

Em Ser e tempo (Sein und Zeit), de 1927, a fenomenologia enquanto via de acesso e verificação do ser dos entes, em suas modificações e sentido, constitui-se como tarefa nuclear de uma ontologia fundamental. "A ontologia só é possível como fenomenologia" 25 , diz Heidegger. Aí, o termo "fenomenologia" é tomado no duplo aspecto de sua constituição: o caráter singular de fenômeno e o caráter universal de logos. Trata-se, portanto, de demonstrar um ente tal como ele se mostra em si mesmo, mas considerando aquilo que, por vezes, se mantém velado diante do que imediatamente se manifesta, o ser dos entes. Por isso, o método fenomenológico assume, na orientação heideggeriana, um duplo caráter: o velamento, o oculto, e o desvelamento, a presença. Do ponto de vista metódico, todavia, a descrição fenomenológica é interpretação. Enquanto interpretação, a hermenêutica constitui-se como condição de possibilidade de uma investigação ontológica, já que "Fenomenologia do 'Dasein' é hermenêutica na significação primitiva da palavra"26. Assim, a filosofia, na condição de uma ontologia fenomenológica, torna-se também uma ontologia hermenêutica, ou seja, uma interpretação sobre o sentido do ser. Em sua formulação de uma fenomenologia hermenêutica, Heidegger põe a hermenêutica a serviço da compreensão do ser, tomando como ponto de partida o aspecto prático que descreve o sentido e as condições do ser humano como ser-no-mundo. Não se trata mais e apenas de um compreender, interpretar, descrever objetos e textos, ou mesmo as coisas do mundo, mas de uma compreensão em sua totalidade, de uma "hermenêutica da facticidade".

A proposta de uma hermenêutica filosófica anunciada por Gadamer tem sua especificidade no modo pelo qual é desenvolvido seu pensamento filosófico. A originalidade e complexidade dessa obra parecem estar ligadas à sua possibilidade de conectar investigações, análises críticas, questionamentos e abordagens, além de uma revisão históricohermenêutica própria, que a época lhe permitia, reconsiderando-as sob uma perspectiva mais ampla e, às vezes, integrando-as a seu projeto filosófico. No entanto, se seu desenvolvimento tem como ponto de partida a problemática da auto-evidência das ciências humanas, a questão

\footnotetext{
${ }^{25}$ M. HEIDEGGER, El ser y el tiempo, p. 46.

${ }^{26}$ Id., ibid., § 7, p. 48 .
} 
central que se articula no conjunto da obra é precisamente o conceito de experiência, cuja amplitude de desdobramento remete-nos à temática da finitude, da verdade e da historicidade. Embora seu impulso ontológico fundamental tenha sido dado por Heidegger, tendo em vista o significado e o horizonte da denominada "hermenêutica da facticidade" - o ser humano na condição de seu modo fático de ser -, o que propõe Gadamer é uma "ontologização da hermenêutica em sentido novo",27.

Do ponto de vista histórico-temático, a referida obra está inserida numa época marcada pela crescente racionalidade científica, cujo espírito técnico e metodológico impõemse nas mais diferentes esferas e por toda parte. Sobressai, a partir de então, a antiga disputa entre as ciências da natureza (Naturwissenschaften) e as ciências humanas (Geisteswissenschaften), ou mesmo o empenho em buscar um pressuposto metodológico mais adequado às ciências humanas, dados seus limites e restrições à ciência moderna. Nessa primeira parte, então intitulada "Liberação da questão da verdade da arte", a discussão sobre a problemática da dimensão estética é inserida num âmbito de retomada do diálogo com as ciências humanas e, mais especificamente, num contexto de discussão metodológica entre as ciências humanas e as ciências da natureza. Entretanto, não podemos perder de vista que, enquanto ponto de partida, o que aí se articula são os fundamentos filosóficos básicos de construção de uma nova proposta de reflexão hermenêutica, cujo intento não é uma formulação metodológica, mas o questionamento sobre a idéia de construção de um saber.

Não se trata, portanto, de articular a hermenêutica como uma ciência da compreensão no sentido de uma teoria da arte (Kunstlehre) do compreender, ou seja, a hermenêtica em seu caráter teórico-instrumental como um sistema de elaboração de regras para descrever ou orientar o procedimento metodológico das ciências humanas ${ }^{28}$. "A questão posta aqui quer

\footnotetext{
${ }^{27}$ Cf. E. STEIN, Aproximações sobre hermenêutica, p. 70. Sobre o impulso fundamental que a filosofia de Heidegger exerce na obra de Gadamer e o conseqüente caráter de valorização ontológica que o problema da compreensão assume na proposta hermenêutica do hermeneuta, ressalte-se um dos momentos do diálogo estabelecido entre Gadamer e Habermas que se stende dos anos 60 aos 80. Trata-se do pronunciamento habermasiano intitulado "Hans-Georg Gadamer: Urbanização da província heidegeriana", proferido por ocasião da entrega do Prêmio Hegel, de 1979 na cidade de Stuttgart. Enquanto discípulo de Heidegger, cujo pensamento radical instala um abismo ao redor de si, a hermenêutica filosófica de Gadamer teria naquele momento o mérito de lançar uma ponte que não apenas neutralizasse o distanciamento entre as ciências humanas e a filosofia, bem como pudesse transpor o abismo ocasionado pela filosofia heideggriana. Habermas explicita melhor essa idéia assim afirmando: "[...] a imagem de ponte sugere falsas conotações [...] Eu preferia dizer que Gadamer urbaniza a província heideggeriana. É claro que deveríamos levar em conta que a palavra 'província' (Provinz), sobretudo em alemão, nós associamos não somente ao limitativo, mas também o teimoso, o cabeçudo (DickschädeligEingenssinnig) e o primitivo ou original (Ursprünglich)" (J.HABERMAS, "Hans Georg Gadamer:Urbanização da Província heideggeriana", in: Dialética e Hermenêutica, p. 74)

${ }^{28}$ A hermenêutica filosófica de Gadamer constitui-se como um contraponto às teorias hermenêticas cujo propósito era uma teoria geral da interpretação e análise da compreensão (verstehen) como método. Entre estas, uma das mais sofisticadas é a teoria de Emilio Betti, expressa em sua obra A hermenêutica como metodologia
} 
descobrir e tornar consciente algo que permanece encoberto e desconhecido por aquela disputa sobre os métodos, algo que, antes de traçar os limites e restringir a ciência moderna, precede-a e em toda parte torna-a possível"29. O núcleo fundamental a partir do qual Gadamer vai definir a singularidade de sua proposta hermenêutica é, pois, o compreender ${ }^{30}$ como forma originária de ser-no-mundo. Num sentido comparável à proposta de Kant, questionam-se aqui as condições de possibilidade do conhecimento, porém, não no sentido do criticismo, de prescrever o alcance da ciência moderna, mas no intento de ultrapassar os limites das experiências científicas, em suas diferentes formas, estendendo-se, assim, a todo horizonte de práxis da vida humana.

A interrogação gadameriana propõe-se a investigar aquilo que antecede todo comportamento compreensivo da subjetividade, bem como o procedimento metodológico das ciências da compreensão. Logo, desenvolve-se a partir de uma suspeita e conseqüente descrédito em toda fundamentação teórica do saber que negligencie nossa experiência ontológica primordial, expressa em nosso relacionamento imediato com o mundo. Além da tradição hermenêutica, a formulação analítica do Dasein $^{31}$ articulada por Heidegger em Ser e tempo (Sein und Zeit), de 1927, é um ponto de partida fundamental e determinante. Trata-se do sentido primordial daquilo que Heidegger desenvolveu sob a expressão "Analítica temporal da existência Dasein" - "[...] mobilidade fundamental do Dasein, o qual perfaz sua finitude e historicidade, e a partir daí abrange o todo de sua experiência de mundo"32. Ao reconsiderar o problema do ser, Heidegger não apenas ultrapassa a metafísica tradicional, como também aprofunda o conceito de compreensão sob uma luz inteiramente nova. A compreensão não é mais um ideal de conhecimento, ou mesmo um ideal metódico da filosofia. O referido fenômeno passa a estar radicalmente vinculado ao modo de ser originário da vida humana, e, dessa forma, a clareza de seu conceito apenas pode ser apreendida na consideração de seu caráter ontológico; ou seja, tomando-o como um existencial, como uma

geral das ciências do espirito (Allgemeine Auslegungslehre als Methodik der Geisteswissenschaften), de 1967, e com a qual Gadamer dialoga.

${ }^{29}$ H.-G. GADAMER, Wahrheit und Method, I, in: GW, I, Vorwort, p. XVII.

${ }^{30} \mathrm{O}$ termo verstehen deriva do verbo stehen, cujo significado implica "estar de pé", "manter-se em". Nesse sentido distingue-se de Verstand, enquanto faculdade de compreensão e intelecto, bem como de begreifen, enquanto procedimento de entender conceitualmente algo.

${ }^{31}$ Tendo em vista a diversidade de designações referentes à tradução do termo Dasein junto ao pensamento de Heidegger, como, por exemplo, "presença", "ser aí", iremos manter sua formulação originária: Dasein.

${ }^{32}$ H.-G. GADAMER, Wahrheit und Method, I, in: GW, I, Vorwort, p. XVIII. Enquanto uma das tendências da hermenêutica contemporânea, ressalta Bleicher, a filosofia hermenêutica contrapõe-se a toda e qualquer metodologia da interpretação objetiva do espírito. O que, fundamentalmente, a caracteriza é o fato de tomar como pressuposto a interpretação do Dasein, ou melhor, uma análise transcendental que, por meio da interpretação do Dasein, tem como meta a construção existencial da compreensão (Cf. J. BLEICHER, Hermenêutica contemporânea, p. 135-6). 
determinação básica categorial do Dasein. O compreender no sentido heideggeriano é uma estrutura do Dasein que não pode deixar de ser. Dessa forma, ao abordar a compreensão como um constitutivo, um modo de ser, fundamental do ser histórico, Heidegger também ultrapassa as discussões vigentes sobre o fenômeno do verstehen como método específico das ciências humanas. Para Gadamer, sua analítica demonstra, de modo indubitável, que a compreensão não corresponde a um tipo de comportamento subjetivo diante de um objeto, determinado pela reflexão e pelo conceito. $\mathrm{O}$ ato de compreender, pelo contrário, designa, sobretudo, a atitude originária de ser-no-mundo que a interpretação busca explicitar, em seu sentido mesmo de Auslegung. "A compreensão projeta o ser do Dasein para a sua destinação de maneira tão originária quanto para a significação, entendida como a mundanidade de seu mundo particular. [...] Uma vez que existe, Dasein compreende-se a si mesmo - sempre se compreendeu e sempre se compreenderá - em função de suas possibilidades"33. Enquanto atitude originária, essa compreensão primária do Dasein não constitui um tipo particular de saber, nem tampouco uma concepção temática no sentido de explicar (Erklären) algo. Além de atitude originária, convém acrescentar, corresponde ainda a um comportamento prático, a maneira pela qual nós nos encontramos aí na relação com o mundo. Mas o que, segundo Gadamer, elucida e ao mesmo tempo confere legitimidade e importância a essa concepção heideggeriana do compreender é a própria significação do termo alemão verstehen. Se, em um primeiro sentido, este verbo refere-se "a um compreender algo", num outro, também corresponde a um saber-fazer, a uma capacidade de desempenho prático ${ }^{34}$, cujo testemunho verifica-se quando, por exemplo, menciono "não ser entendido na realização de alguma atividade ou tarefa". Atentando às duas acepções consideradas, o ato de conhecer parece ser comum a ambas, pois reúne tanto "um ser entendido em algo" como "um saber-situar-se para um tal desempenho". Por conseguinte, a compreensão não significa um dirigir-se rumo à captura de um significado, mas um projetar-se a diferentes possibilidades de interpretação no exercício de sua própria liberdade de espírito. Nesse sentido, compreender constitui-se como abertura, constituição existencial do Dasein, em função da qual o mundo se abre como tal. Trata-se de um fenômeno que expõe a mútua dependência entre Dasein e mundo; uma espécie de retorno da existência a si mesma a partir das possibilidades as quais realiza. Daí que compreender refere-se ao poder ser (Möglichsein) do Dasein. A superação do modelo epistemológico da compreensão alcança a reflexão de Heidegger mediante o seu modo novo

\footnotetext{
${ }^{33}$ M. HEIDEGGER, El ser y el tiempo, § 31, p. 163.

34 "Verstehen tem um sabor prático: verstehen seguido de um infinitivo significa 'compreender, saber como fazer algo', e sich verstehen auf significa 'compreender, saber como fazer, lidar com algo"' (M. INWOOD, Dicionário Heidegger, p. 18).
} 
de entender a expressão 'sich auf etwas verstehen', no sentido de um entender-se com relação a algo. Portanto, entender implica estar à altura de algo, ser capaz enquanto habilidade essencialmente prática. Só assim podemos melhor compreender a seguinte afirmação: eu me entendendo em relação a isto ou àquilo; ou eu sou capaz disto.

É, pois, assim que alguém se entende em relação ao saber nadar ou mesmo andar de bicicleta, não no sentido de empregar bons métodos para esses fins, mas porque essencialmente se é capaz de atingi-los. Apenas sabe andar de bicicleta, ou mesmo desempenhar qualquer atividade, aquele que, de fato, sabe realizá-la. Isto parece esclarecer o compreender enquanto modo de abertura originária de poder, uma vez que este corresponde a um caráter determinante do Dasein. "Aquele que compreende atua como uma criança que de repente se dá conta de que é capaz de montar em uma bicicleta e que, por pura emoção não se dá conta de que vai demasiado depressa e que vai fazendo isso de um lado para o outro"35.

$\mathrm{Na}$ verdade é a partir desse caráter de "poder ser" enquanto possibilidade real do Dasein que se desenvolve a noção heideggeriana de projeto (Entwurf), cuja repercussão no século XX é bastante ampla. Enquanto "poder ser" que o constitui, o Dasein compreende-se também como projeto. $\mathrm{Na}$ analítica existencial desenvolvida por Heidegger, convém esclarecer, a noção de projeto corresponde a uma determinação formal da existência, ou seja, ele não comporta nenhuma determinação prévia, não possuindo, portanto, nenhum conteúdo preestabelecido, direção ou mesmo plano estabelecido. O que aqui está em jogo é o projetarse da própria existência, não algo desta. É precisamente por isso que, segundo Heidegger, não tem sentido falar de uma auto-reflexão enquanto uma autoconstituição absoluta independentemente desse inserir-se às possibilidades do mundo com as quais deparamos. Do ponto de vista do Dasein, ser e compreender constituem um movimento simultâneo, de modo que projeta compreendendo quem compreende projetando. Esse caráter constante do projetarse que, por sua vez, perfaz o próprio movimento do compreender constitui-se também como "saber se ocupar" no intuito de descobrir o que ali se esconde ou se dissimula ${ }^{36}$. Enfatiza Gadamer: “[...] todas as compreensões reduzem-se, finalmente, ao nó comum de um 'eu sei como me ocupar ali', isto é, a uma compreensão de si em relação a alguma outra coisa” ${ }^{\circledR 37}$.

Mas, além da valorização ontológica do problema da compreensão, sua estrutura também é tomada em seu caráter histórico. A existência humana, em seu horizonte projetivo

\footnotetext{
${ }^{35}$ J. GRONDIN, Introducción a Gadamer, p. 43.

${ }^{36}$ Cf. H.-G. GADAMER, "Martin Heidegger e o significado de sua 'hermenêutica da facticidade' para as ciências humanas", in: Le problème de la conscience historique, p. 49-57.

${ }^{37}$ Id., ibid., p. 51.
} 
do Dasein, é essencialmente orientada para o futuro, acumulando o saber histórico. O pertencimento (Zugehörigkeit) do Dasein à sua finitude histórica, à sua tradição, revela também o fato de esse ser-aí constituir-se como um ser-lançado (Geworfenheit), encontrandose sempre como um projeto (Entwurf) orientado para suas futuras possibilidades ${ }^{38}$. Dessa forma, sendo o compreender o modo de realização da historicidade do Dasein mesmo, sua dimensão hermenêutica consistiria no próprio caráter de finitude e historicidade determinantes de sua experiência no mundo.

Retomando o caráter de abrangência e universalidade do fenômeno de compreensão como um existencial, bem como seu engajamento real e efetivo, resultante da analítica heideggeriana $^{39}$, o propósito de Gadamer será a atualização do significado filosófico da hermenêutica tendo em vista o fundamento de sua orientação ontológica ${ }^{40}$. O que torna o ser humano um ser hermenêutico é justamente o fato de sua experiência total de mundo ser constituída por sua experiência da finitude e da historicidade. Daí, para Gadamer, o caráter de importância de repensar a hermenêutica a partir da analítica heideggeriana da temporalidade do Dasein. Eis ainda o que fundamenta a condição de passagem de uma hermenêutica

\footnotetext{
${ }^{38}$ Para Gadamer, o que há de fundamental na concepção heideggeriana de compreensão não é simplesmente tomá-la como um existencial, mas precisamente o que daí decorre enquanto uma nova dimensão e importância. "A estrutura existencial do pro-jeto lançado, fundamento da compreensão como operação significativa do Dasein, é a estrutura que também se encontra na base da compreensão que tem lugar nas ciências humanas. [...] A importância de uma doutrina existencial como a do 'ser lançado' [Geworfenheit] consiste precisamente em mostrar que o Dasein que se projeta ao seu futuro 'saber-ser' é um ser que, desde sempre, já foi, de modo que todo seu livre comportar-se choca-se e detém-se na facticidade de seu ser." O Dasein é, na estrutura de sua facticidade, inevitavelmente precedido por essa idéia de projeto enquanto possibilidade e finitude.

${ }^{39}$ Em Texto e interpretação (Text und Interpretation), de 1984, Gadamer afirma que o estímulo e ponto de partida para sua crítica ao idealismo e ao metodologismo da era da teoria do conhecimento como via de ampliação da problemática hermenêutica foram a análise crítica e polêmica do conceito de "compreensão" segundo Heidegger. "Para sua análise crítica [...] da compreensão, Heidegger apoiou-se no antigo discurso sobre o círculo hermenêutico, reivindicou-o como um círculo positivo e em sua analítica do Dasein elevou-o a conceito [...]. O conceito de círculo hermenêutico significa que no âmbito da compreensão não se pretende deduzir uma coisa de outra [...], mas representa a descrição adequada da estrutura do compreender. Dilthey, seguindo a Schleiermacher, introduziu a expressão 'círculo hermenêutico' em contraste com o ideal de raciocínio lógico. Se considerarmos o verdadeiro alcance do conceito de compreensão no uso da linguagem, veremos que a expressão 'círculo hermenêutico' sugere na realidade a estrutura do ser no mundo, quer dizer, a superação da divisão entre sujeito e objeto na analítica transcendental do Dasein levada a cabo por Heidegger" (H.-G. GADAMER, WM, II, p. 331). A propósito da reflexão hermenêutica de Heidegger acerca da compreensão enquanto possibilidade positiva de um conhecimento mais originário, ver também Sobre o círculo da compreensão, 1959.

${ }^{40}$ Repensar a tarefa fundamental da ontologia é o traço determinante na reflexão hermenêutica de Gadamer. Nesse sentido, sua pretensão mesma não é fundamentar as ciências humanas, mas reformular a filosofia tendo em vista uma nova ontologia hermenêutica. Daí que a hermenêutica não é um problema específico de metodologia, mas sim de ontologia, com base na experiência de finitude e historicidade. Posteriormente retomaremos essa questão no sentido de precisar melhor o sentido dessa ontologia reformulada pela hermenêutica filosófica de Gadamer.
} 
moderna de caráter mais psicologizante, expressa nos pensamentos de Schleiermacher e Dilthey, para uma hermenêutica eminentemente histórica ${ }^{41}$.

Ao longo do desenvolvimento do pensamento filosófico de Gadamer, torna-se bastante evidente que a discussão e os propósitos de sua hermenêutica filosófica não podem prescindir de sua própria atualidade, pondo à parte a tradição científica da modernidade. Por isso, suas diretrizes e análises são definidas considerando-se o âmbito de surgimento dos conceitos modernos de método e de ciência. Sua meta, conforme acima mencionamos, não é o desenvolvimento de um novo método, mas, sobretudo, a investigação do fenômeno da compreensão em sua abrangência, e, de modo bem específico, suas condições próprias às ciências humanas (Geisteswissenschaften). Essa argumentação é articulada de modo muito enfático, já que são decisivas para a construção de identidade da hermenêutica filosófica.

Desse modo, à medida que o desenvolvimento de sua tarefa crítica vincula-se a uma tendência contrária à reivindicação universal da metodologia científica, no âmbito da ciência moderna, também define como diretriz fundamental a seguinte meta: "Procurar por toda parte a experiência de verdade, que ultrapassa o campo de controle da metodologia científica, e indagar por sua própria legitimação, onde quer que a encontre" ${ }^{, 42}$.

Ora, a questão é que essas experiências extracientíficas - mais próximas das ciências humanas -, como a experiência da arte, da filosofia e da história, são tradicionalmente rotuladas como manifestações de um tipo de verdade cuja verificação é incompatível com os procedimentos metódicos da ciência. Dessa forma, como então legitimar filosoficamente essas esferas de verdade? O enfrentamento hermenêutico dessa questão justifica, sob a forma de um retorno, a retomada do fenômeno da compreensão, mediante a análise heideggeriana, acima mencionada. Afinal, como lembra Gadamer, "é tarefa da hermenêutica esclarecer o milagre da compreensão, que não é uma comunicação misteriosa entre as almas, mas participação num sentido comum"43. É apenas com base nessa redefinição conceitual, em que a constituição do sentido não é artifício de uma subjetividade isolada e distanciada da história, mas só pode ser explicada a partir dessa relação de pertencimento à tradição, que se torna possível identificar e comprovar o quanto de acontecimento (Geschehen) age em toda e qualquer compreensão humana. Radicado à sua própria facticidade, o Dasein enquanto compreensão não pode desatar-se do vínculo a costumes e tradições que co-determinam sua

\footnotetext{
${ }^{41}$ A esse respeito, Einführung in die philosophische Hermeneutik, de J. GRONDIN, merece uma atenção especial.

${ }^{42}$ H.-G. GADAMER, $W M$, I, p. 1.

${ }^{43} I d$., ibid., II, p. 58.
} 
experiência de mundo. Eis o fundamento de análise a partir do qual se torna possível e necessária, para Gadamer, "a tentativa de um acordo sobre o que são, na verdade, as ciências do espírito, para além de sua autoconsciência metódica, e o que as vincula ao conjunto de nossa experiência do mundo" ${ }^{, 4}$. O que aqui está em questão é o compreender como um acontecer, como ocorrência, e não o que fazemos ou deixamos de fazer.

Assim, conforme mencionamos anteriormente, é o problema da correta autoconcepção das ciências humanas (Geisteswissenschaften) em face das ciências naturais (Naturwissenschaften) que constitui o incentivo à elaboração dessa obra ${ }^{45}$. Em torno deste, escreve Gadamer: "É inútil [...] limitar a elucidação da natureza das ciências humanas a uma pura questão de método. Não se trata, em absoluto, de definir simplesmente um método específico, mas sim de fazer justiça a uma idéia inteiramente diferente de conhecimento e de verdade" ${ }^{\$ 4}$. Enquanto uma doutrina da arte de entender, como a concebia Schleiermacher ${ }^{47}$, a hermenêutica tradicional, pensava Gadamer, estava voltada a um sentido demasiadamente técnico. Mas, por um lado, a hermenêutica não se pode reduzir a um caráter eminentemente metódico, e, por outro, não o pode suprimir. $\mathrm{O}$ fato da concepção gadameriana de experiência hermenêutica ultrapassar o domínio de controle da metodologia científica não deve, contudo, resultar na compreensão de uma radical oposição entre experiência hermenêutica e método, como assim ressalta Habermas em uma de suas argumentações críticas dirigidas à Verdade $e$ Método. Afirma este: “A confrontação de 'Verdade' e 'Método' não deveria ter induzido Gadamer a contrapor abstratamente a experiência hermenêutica ao conhecimento metódico como um todo. Este é, afinal, o chão das ciências hermenêuticas; e mesmo que se tratasse de afastar totalmente as humanities do âmbito da science, as ciências da ação não escapariam da vinculação de procedimentos empírico-analíticos com procedimentos hermenêuticos. A reivindicação, que a hermenêutica legitimamente faz valer contra o absolutismo, também cheio de conseqüências práticas, de uma metodologia geral das ciências das experiência não

\footnotetext{
${ }^{44}$ H.-G. GADAMER, $W M$, I, p. 3.

${ }^{45}$ Convém mencionar que, no período de 1936 a 1959, Gadamer desenvolveu cursos sob o título de "Introdução às Ciências do Espírito", estabelecendo uma concepção de hermenêutica compatível com essas ciências. Nos anos 50 esses cursos surgem como desenvolvimento de respeitáveis teses sobre o problema de verdade nas ciências do espírito - como nas Conferências de Louvain (1957) -, sobre o Problema da consciência histórica, e em 1960 estes culminam com a publicação de Wahrheit und Methode. Le problème de la conscience historique é o título original dessas conferências de Gadamer. Seu surgimento em 1963 é antecedido pela publicação de Verdade e método. Com diz Gadamer, na introdução dessa obra, trata-se de um substituto para o público francês de sua obra mais copiosa, até então acessível apenas em alemão.

${ }^{46}$ H.-G. GADAMER, Le problème de la conscience historique, p. 27.

47 "As regras hermenêuticas têm que ser mais método" (F. SCHLEIERMACHER, Hermeneutik und Kritik, p. $84)$.
} 
dispensa de todo o trabalho da metodologia $[\ldots]^{, 48}$. Todavia, a hermenêutica filosófica tem como empenho ratificar os limites de uma tecnologia da compreensão e, portanto, do horizonte metodológico da ciência moderna para efetivamente compreender a amplitude do âmbito das experiências humanas. Sua pretensão é fundamentalmente filosófica, posto que tem como propósito “ [...] não o que fazemos, não o que deveríamos fazer, mas o que, além de nosso querer e poder, acontece, está em questão,49

A esse respeito diz Grondin: "Seria um mal-entendido ver na hermenêutica de Gadamer uma alegação 'contra o método' (como sucede, por exemplo, com Paul Feyerabend, em sua obra Against Method). Há que se seguir métodos, se se quer construir uma ponte, resolver um problema matemático, [...] Isto é óbvio para Gadamer, e a ele nunca ocorreu discuti-lo. Gadamer mesmo aprendeu muito das metodologias - muito apreciadas por ele das ciências. Por conseguinte, o que censura não é a ciência metódica como tal, mas a fascinação que emana dela e que nos seduz a entender de maneira puramente instrumental o compreender, e a errar ao assim entendê-lo"50. Isso talvez justifique a razão pela qual seu projeto de uma hermenêutica filosófica tenha se voltado bem menos à teoria da ciência moderna e bem mais ao retorno às tradições.

Desse modo, junto às tradições mais antigas ${ }^{51}$, o testemunho da arte é especialmente tomado como "[...] a mais insistente advertência à consciência científica, no sentido de que se reconheçam seus limites" ${ }^{\sharp 2}$. Nela revela-se uma concepção de compreender que, todavia, não é instrumental. Se, de modo geral, tornou-se evidente o domínio da ciência moderna, ao mesmo tempo, parece também ser providencial ter presentes seus limites, ainda que para isso tenhamos de recorrer a outras tradições. Por isso, segundo Gadamer, em vez de a hermenêutica buscar assegurar-se por meio de regras, o que acarretaria a fragilidade de uma compreensão, seus fundamentos devem ser buscados em uma experiência de verdade que não se renda a um ideal de seguridade consoante o domínio da ciência moderna; uma experiência de verdade que, fundamentalmente, "supere o âmbito de controle da metodologia científica" ${ }^{33}$.

\footnotetext{
${ }^{48}$ J. HABERMAS, “Sobre Verdade e Método, de Gadamer", in: Dialética e hermenêutica, p.13-4.

${ }^{49}$ H-G. GADAMER, $W M$, I, p. XVI.

${ }^{50} \mathrm{~J}$. GRONDIN, Introducción a Gadamer, p. 41.

${ }^{51}$ Essa experiência extracientífica de verdade é buscada por Gadamer em tradições valiosas, cujo esquecimento implica a necessidade de sua reabilitação como uma forma de considerável contribuição. Assim, tem-se a tradição retórica, a filosofia prática e a hermenêutica jurídica e teológica.

${ }^{52}$ H-G. GADAMER, $W M$, I, p. 2.

${ }^{53}$ Id., ibid., p. 1. Assim, tem-se a tradição retórica, a filosofia prática e a hermenêutica jurídica e teológica.
} 
A ênfase de tal afirmação, feita já na introdução da obra, justifica, desde então, a trilha escolhida pelo autor, como bem estimula a investigação de nossa questão central, qual seja, o que justifica a análise da experiência artística como horizonte inicial de questionamento hermenêutico?

Reivindicar para a arte seu valor de verdade representa aqui o primeiro grande impulso não só para valorizar a base ontológica de seu pensamento, mas também para possibilitar o reconhecimento interpretativo de toda e qualquer experiência humana. Se o projeto de uma hermenêutica filosófica está radicalmente vinculado a uma base ontológica de reflexão, tendo em vista o caráter ontológico-existencial inerente ao fenômeno da compreensão, nada como submetê-la a um campo da experiência que, por muito tempo, esteve separado da verdade. Resgatar para a arte uma condição de tal importância implica reconsiderá-la como esfera privilegiada em que a verdade se expõe. O empreendimento de tal análise apresenta-se, por conseguinte, como primeira tarefa de fundamentação da hermenêutica filosófica gadameriana. A arte constitui-se, por fim, como o testemunho mais importante de experiência de verdade a ser recuperado; eis o ponto de partida da obra Verdade e método, bem como o núcleo temático de nossa pesquisa.

Ressalte-se, no entanto, que a compreensão ontológico-hermenêutica da arte como experiência de verdade propriamente dita é antecedida e justificada por uma discussão de âmbito epistemológico, cujo objetivo é questionar o paradigma do método da ciência moderna como condição suficiente e necessária para compreender a totalidade das experiências humanas. A racionalidade hermenêutica que aqui se apresenta surge como exigência de uma época caracterizada não apenas por uma hostilidade de viés tecnológico para com o histórico, mas também pela autolimitação metódica do conhecimento.

Essa argumentação de Gadamer é de fundamental importância, na medida em que nos remete à problemática epistemológica das ciências humanas (Geisteswissenschaften) ou ciências históricas ${ }^{54}$ modernas, denominação vigente na época. A tomada de uma consciência

\footnotetext{
${ }^{54} \mathrm{Na}$ reflexão de Gadamer, a problemática hermenêutica, enquanto atividade de compreensão, originou-se no campo da teologia e da jurisprudência, bem como mediante a irrupção do humanismo, de acordo com a assimilação dos clássicos latinos e gregos como modelos de superioridade cultural. Entretanto, diante do processo de modernização, ela passa a assumir outras proporções: "[...] a questão da hermenêutica penetrou mais fortemente na questão filosófica do problema não só quando teve de superar em âmbitos particulares uma distância de altura e uma distância de longitude - como era o caso dos documentos religiosos, dos textos legais ou dos clássicos em línguas estrangeiras -, mas também quando o todo da tradição histórica deslocou-se para uma grande distância. E isso sucedeu à raiz de grande ruptura da tradição que a Revolução Francesa significou, trazendo como conseqüência a cisão da civilização européia em culturas nacionais. A tradição comum do mundo político cristão da Europa, que por certo continuou subsistindo sobre o cenário deste novo desenvolvimento, ao desaparecer sua validade evidente, penetrou de uma maneira nova na consciência, como modelo escolhido, como
} 
histórica do presente e da relatividade de opinião, no horizonte particular de suas perspectivas, já desde o início da época moderna, constitui uma grande revolução, bem como um privilégio. Já não basta a reclusão nos limites exclusivos de uma tradição, pois torna-se preciso considerar nossa própria perspectiva em relação ao outro. Abre-se à perspectiva da alteridade e busca-se compreender a pluralidade dos pontos de vista, o horizonte histórico no qual coexistimos. Emerge a predisposição reflexiva de interpretá-lo. Eis o tipo de reflexão que caracteriza as Geisteswissenschaften. Estas, por sua vez, na investigação de seus métodos específicos - histórico-críticos -, continuavam atraídas pelo modelo das ciências da natureza, única forma de assegurarem sua consciência científica, mediante a eliminação de seu elemento subjetivo. O problema que aí se põe é, todavia, que não é por analogia ao método das ciências matemáticas da natureza, forjando-se um método próprio, que a autonomia das ciências humanas será conquistada, adverte Gadamer. Entender essa impossibilidade, no entanto, significa buscar compreender a razão de ser de sua própria iniciativa.

Qual a origem dessa tentativa de buscar a legitimidade científica das ciências humanas com base na idéia de método da ciência moderna? Compreender o problema de legitimação epistemológica das ciências humanas significa, na análise gadameriana, tanto voltar-se à gênese de seu sentido, à sua tradição ${ }^{55}$ histórico-conceitual, quanto elucidar a própria significação do método apresentada por Gadamer. É precisamente com base na história da palavra Geisteswissenschaften que se iniciam os esclarecimentos dessa questão. Sua origem, lembra-nos o hermeneuta, advém da tradução alemã do Sistema da lógica de Stuart Mill, que converteu a expressão "moral sciences" em Geisteswissenschaften (no Livro 6, cujo título é Von der Logik der Geisteswissenschaften oder moralischen Wissenschaften). Sendo o método indutivo a base de toda ciência experimental, constitui-se também como o único válido para a autocompreensão dos fenômenos morais e sociais.

Nessa formulação, confirma-se o já previsto por toda uma tradição inglesa e que está claramente exposto no Tratado da natureza humana de David Hume, ou seja, "[...] as ciências morais não constituem exceção quando procuramos uniformidades, regularidades e leis com

objetivo do saber pela nostalgia e, afinal, como objetivo do saber histórico. Pois o passado, enquanto tal, torna-se estranho. Todo reencontro com a tradição deixou de ser uma simples apropriação, que a recolhia de modo tão óbvio quanto ao antigo e que teve de superar os abismos que separavam o presente do passado" (H.-G. GADAMER, "Hermenêutica como filosofia prática", in: A razão na época da ciência, p. 65).

${ }^{55}$ Baseando-se na exposição de Heidegger sobre a pré-estrutura da compreensão, Gadamer eleva a historicidade da compreensão - condicionamento histórico do processo de interpretação - à condição de princípio da hermenêutica. Em si mesma, a compreensão não constitui uma atividade subjetiva, mas um acesso ao processo da tradição em que passado e presente condicionam-se constantemente. 
vistas à previsão de fatos e ocorrências particulares" ${ }^{\sharp 6}$. Em decorrência dessa concepção, ao longo do século XIX, a lógica das ciências humanas (Geisteswissenschaften) é inteiramente dominada pelo modelo das ciências da natureza, carecendo de uma lógica própria.

Disso resulta aquilo que representa o verdadeiro problema posto pelas ciências humanas, isto é, a impossibilidade de compreendermos sua natureza tendo em vista o padrão de conhecimento progressivo da legalidade, uniformidade e regularidade que tornariam previsíveis os fenômenos e processos individuais. Ressalta Gadamer:

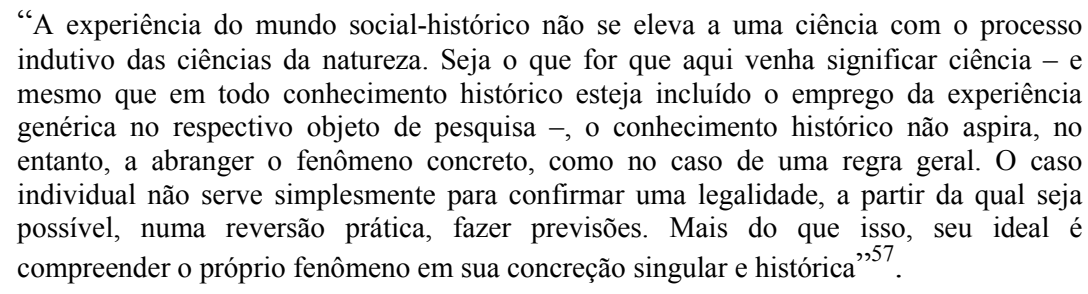

Mas, por um lado, Gadamer está convicto de que não é com base na concepção de ciência moderna que as ciências históricas atingirão seu processo de autonomia e legitimidade, e, por outro, o horizonte de sua análise remete-nos a uma outra discussão metodológica, cuja argumentação insere-nos em seu diálogo com o historicismo. Trata-se de uma crítica contrária à idéia de que as ciências do espírito, para garantir-se o estatuto de ciência, deveriam, enquanto um grupo independente de natureza própria, elaborar métodos específicos, e não se submeter a uma adaptação teorético-científica com base nas ciências da natureza. Nesse modo de pensar articulavam-se as orientações metodológicas de Droysen ${ }^{58}$, Dilthey e do neokantismo em geral.

Na realização de seu projeto hermenêutico, Dilthey, com certeza, constitui-se em um dos grandes interlocutores de Gadamer, exercendo influência sobre ele e possibilitando-lhe discordâncias e críticas quanto à proposta de autonomia das ciências do espírito. Partindo da mesma problemática - fundar as ciências do espírito, diferenciando-as das ciências da natureza -, ambos desenvolvem um debate com o ideal metodológico naturalista, ao qual estão submetidas as ciências do espírito. Entretanto, a reflexão de Gadamer identifica a Extensão e limites da obra de Dilthey - título de uma de suas conferências -, ressaltando a

\footnotetext{
${ }^{56}$ H.-G. GADAMER, Le problème de la conscience historique, p. 30.

${ }^{57}$ H.-G. GADAMER, $W M$, I, p. 10.

${ }^{58}$ Para Droysen, a história constitui um campo científico destituído de uma delimitação e articulação teórica. Uma vez aprofundado, seu conceito há de ser "o ponto de gravitação em redor do qual a desordenada oscilação das ciências do espírito tem a ganhar firmeza" (J.G. DROYSEN, Historik, p. 97, citado em H.-G. GADAMER, $W M$, I, p. 12).
} 
insuficiência de seu propósito fundamental. Mesmo sem o objetivo de proceder a uma análise minuciosa, convém fixar-nos em algumas de suas argumentações, sobretudo por isso nos permitir uma compreensão complementar acerca da especificidade da relação entre estética e hermenêutica no tocante à experiência da obra de arte, no pensamento de Gadamer.

Uma vez que o mundo histórico é introduzido no desenvolvimento autônomo da razão, torna-se necessário investigar, no cerne de sua experiência, um fundamento consistente; algo compatível com aquela contribuição dada por Kant para a criação e justificação da ciência natural e da matemática. A busca dessa fundamentação encontra na razão histórica a descoberta que conduz Dilthey à pretensão de completar a Crítica da razão pura de Kant por meio de uma "crítica da razão histórica". E, se a acuidade desse problema mostrava-se a outros pensadores representantes do historicismo, como Duhem e Droysen, em Dilthey ele persiste sob a forma dos seguintes questionamentos. Tendo em vista o caráter histórico de nosso ser e de nosso conhecer, como converter em conhecimento objetivo aquilo que é historicamente condicionado? Como possibilitar à consciência histórica ultrapassar a relatividade que lhe é intrínseca, legitimando a objetividade e a independência das ciências humanas? Como objetivar o conhecimento e a formulação das leis da vida do espírito que devem servir de fundamento comum às diferentes ciências humanas?

Às ciências particulares do espírito, cabe a tarefa de conhecer a realidade históricosocial, dada a íntima conexão entre vida espiritual e espírito histórico - a vida espiritual é histórica em todos os seus pontos. E, quanto à legitimidade de sua autonomia, essa depende exclusivamente da natureza de seu fundamento. Um dos pontos de sustentação das investigações hermenêuticas de Dilthey é sua firme conviç̧ão de que, se "toda ciência é ciência da experiência" ${ }^{59}$, logo prevê uma conexão direta com as condições de nossa consciência, dentro da qual a experiência surge. Assim sendo, "todas as constatações das ciências humanas (Geisteswissenschaften) referem-se, em última instância, aos fatos da 'experiência interior': um domínio de ser que não diz respeito à explicação, e sim à compreensão" ${ }^{60}$. Portanto, é do ponto de vista gnosiológico, mediante o qual a realidade constitui-se como fato da consciência, dado na experiência interna, que as ciências humanas (Geisteswissenschaften) buscam sua independência. Sua fundamentação filosófica, por conseguinte, só é possível a partir de uma relação adequada entre teoria do conhecimento e

\footnotetext{
${ }^{59} \mathrm{~W}$. DILTHEY, Introducción a las ciencias del espíritu, p. 5.

${ }^{60}$ H.-G. GADAMER, Le problème de la conscience historique, p. 36.
} 
psicologia, o que se expressa por meio da idéia de uma Geisteswissenschaftliche Psychologie, em oposição à idéia de uma psicologia meramente explicativa.

É necessário que a filosofia tome consciência de uma conexão radical que existe entre a diversidade de seus sistemas e a vida. As concepções de mundo e da vida tornaram-se muitas, e a possibilidade de suas demonstrações fez-se insatisfatória, haja vista as contradições, refutações e pluralidade dos aspectos da vida em face da realidade efetiva. A diversidade dos sistemas filosóficos, todavia, manifesta apenas a expressão completa da vitalidade. Tal compreensão, no entanto, pressupõe além de uma fundamentação histórica cujo propósito é indagar como a consciência histórica converte em seu objeto a filosofia e a concepção da vida e do mundo ${ }^{61}$-, uma fundamentação também psicológica.

Em Teoria das concepções do mundo ("Weltanschauungs Lehre") e mais especificamente em seu escrito A consciência histórica e as concepções do mundo ("Das geschichtliche Bewusstsein und die Weltanschaunngen) Dilthey busca justificar a tarefa de entendimento da filosofia com a consciência histórica - "aplicação da consciência histórica à filosofia e à sua história" ${ }^{\natural 2}$. Se as propriedades fundamentais dos sistemas filosóficos só podem ser estudadas uma vez consideradas as manifestações do espírito humano, quais sejam, as formas de religiosidade e da arte, a psicologia, por sua vez, em seu caráter explicativo sustenta Dilthey -, não consegue deduzir dos diversos sistemas filosóficos uma explicação segura dessas profundas manifestações às quais se expressa uma concepção da vida e do mundo. "Toda a nossa vida interior gravita em torno das conexões em que nossa vida própria está inserida. [...] Que todo o dentro busque expressão num fora e, por isso, produza sempre símbolos tem decerto uma condição em nosso mecanismo reflexo, mas não é dele derivável" ${ }^{63}$. Assim, do ponto de vista psicológico, é a partir da "estrutura da vida anímica" enquanto uma condição concreta da vida humana que Dilthey vai sustentar sua fundamentação. Nesta estrutura condiciona-se a relação entre o sujeito e a exterioridade, enquanto uma relação originária da vida, para além da qual não pode também o pensamento recuar. A vitalidade exterior e a exterioridade do mundo mantêm-se sempre juntas e em

\footnotetext{
61 "Uma filosofia que tem consciência de sua relatividade, que reconhece a lei da finitude e da subjetividade em que se encontra, é o deleite improfícuo do erudito: já não cumpre a sua função [...] o espírito humano deve tentar remontar às relações objetivamente cognoscíveis em que a sistemática filosófica, em sua evolução e em suas formas, encontra-se com a natureza humana, com os objetos a ela dados, com suas idéias e seus fins: se as concepções da vida e do mundo se alteram, e modificam, a auto-reflexão histórica que a filosófica traz de si deve buscar na vida humana e em suas referências ao que lhe resiste e sobre ela atua o fundamento firme de toda historicidade, da luta das concepções do mundo. A filosofia, enquanto fato histórico humano, deve para si mesma tornar-se objeto" (W. DILTHEY, Teoria das concepções do mundo, p. 29).

${ }^{62}$ Id., ibid., p. 20.

${ }^{63}$ W. DILTHEY, Teoria das concepções do mundo, p. 32.
} 
referência recíproca. Nossa existência individual e impulsiva não pode prescindir daquilo que “[...] está sempre aí para nós, num nível qualquer”" ${ }^{64}$ o mundo. Por isso, jamais nossa percepção pode está desligada, solta, dessa referência de reciprocidade, para a qual tanto o "si mesmo" e o mundo, bem como o "ideal da vida" e a "visão do mundo" são correlatos. A vitalidade é, desde já, uma expressão inter-relacionada da visão da vida e do mundo; "da vida com a consciência daquilo que o homem vive, experimenta e olha em sua totalidade, na urdidura de vida própria e mundo" ${ }^{\circ 5}$.

A idéia de uma Geisteswissenschaftliche Psychologie refere-se, portanto, a esse esquema de atuação no qual a vida sempre se determina, a essa unidade de nossa existência e de sua referência ao mundo, que, mesmo de caráter inexplicável ${ }^{66}$, constitui-se inerentemente a nosso ser psicológico.

Retomando-se o propósito de Dilthey em compreender as ciências humanas, a pergunta pelo seu fundamento tem como resposta a própria compreensão da consciência histórica, na medida em que ela se põe numa relação com ela mesma e com a tradição: ela compreende a si mesma, através de sua própria história. "A consciência histórica é um modo do conhecimento de si”, ${ }^{\prime \prime}$. Tal formulação, no entanto, impõe para Dilthey a afirmação da seguinte tese: é somente com base na análise da essência do conhecimento de si que se torna possível compreender a gênese de uma consciência científica. O ponto de partida é então a suposição do fenômeno natural da vida, ao qual estão inevitavelmente vinculados a reflexão e o saber. Vida cujo sentido apresenta-se no horizonte de suas manifestações, entre as quais se encontra a arte - "[...] meio privilegiado pelo qual se compreende a vida, já que, situada 'nos confins do saber e da ação', ela permite que a vida revele-se a si mesma em uma profundidade a que a observação, a reflexão e a teoria já não têm acesso"68. Note-se que aqui a experiência da arte surge como expressão de vitalidade, na qual as visões da vida e do mundo estão tomadas como um todo articulado; uma manifestação do mundo espiritual, cujo sentido e profundidade não podem ser apreendidos pelas leis do pensamento reflexivo, próprio do

\footnotetext{
${ }^{64} I d$., ibid., p. 33.

${ }^{65}$ Id., ibid., p. 34.

66 "Visto que a psicologia pode apreender as urdiduras concretas, etc., está realmente na situação de fomentar o estudo histórico. A psicologia dos povos foi um esboço muito engenhoso. Explicou muitas vezes também efetivamente os processos históricos, ao assinalar as formas psíquicas em que transcorreram. Mas fracassou [...] A psicologia, porém, não é nenhuma ciência explicativa. Por isso o método não é o mesmo na ciência natural matemática. Não pode explicar, etc. O método só pode, portanto ser o seguinte: busca das conexões, etc.” (Id., ibid, p. 43).

${ }^{67}$ H.-G. GADAMER, Le problème de la conscience historique, p. 39.

${ }^{68}$ Id., ibid., p. 40.
} 
raciocínio científico moderno. Também na concepção de Dilthey, a experiência da arte constitui uma advertência à consciência científica, já que por meio das leis teórico-subjetivas da reflexão não a podemos compreender como expressão direta de uma visão de mundo e do sentido da vida. Assim como para Gadamer, para Dilthey, "a arte tem também de dizer algo que não se pode expressar em nenhuma outra forma de manifestação da vida humana [...]",69.

Além das considerações acima expostas, que, de certa forma, aproximam ou ainda influenciam a formulação crítica da proposta de uma hermenêutica filosófica, é de modo bem objetivo que Gadamer sustenta os limites e até mesmo o malogro filosófico do pensamento de Dilthey, em seu esforço de fundar as ciências humanas. Do fundamento da vida inerente ao saber - imanência do saber à vida -, desdobra-se sua tendência essencial de investigação tanto para a meditação filosófica, quanto para a busca da objetividade do conhecimento científico. O que sua investigação tem em mira não é bem a busca de um método particular às ciências do espírito resultante da adaptação metodológica dos procedimentos inerentes às ciências da natureza, mas a tentativa de criar condições de possibilidade para que aquelas possam realizar um conhecimento histórico e, ao mesmo tempo, objetivo ${ }^{70}$. Ao reivindicar para as ciências humanas (Geisteswissenschaften) um ideal de objetividade, Dilthey, de fato, pretendia garantir-lhes uma importância compatível à das ciências exatas; daí se preocupar com descrições metodológicas e resultados. O conhecimento produzido pelas ciências humanas tem, entretanto, a sua validade e o caráter de objetividade baseado unicamente nas regras da experiência, sempre submetidas à prova.

Se à vida, em sua tendência natural, é inerente o desempenho de uma reflexão (Besinnung) - imanência do saber à vida -, é porque também a própria filosofia está enraizada no fator primordial da vida, no caráter mesmo de sua reflexividade. Enquanto filosofia da vida, segue, porém, a perspectiva de uma Selbstbesinnung histórica. Preocupando-se com o problema do relativismo, Dilthey, no entender de Gadamer, busca garantir um caráter de objetividade às relatividades, ou mesmo explicar a possibilidade de valores restritos a um momento histórico poderem assumir uma dimensão de caráter absoluto.

É com base, todavia, na denúncia de um cartesianismo latente presente no pensamento de Dilthey que Gadamer assinala os limites de seu desempenho filosófico ao pensar a

\footnotetext{
${ }^{69} \mathrm{~W}$. DILTHEY, Teoria das concepções do mundo, p. 46.

${ }^{70}$ Como nos diz Bleicher, "a condição de as Geisteswissenschaften serem úteis à atividade sociopolítica cria, segundo Dilthey, a necessidade de seus resultados aspirarem a um grau de certeza e generalidade que, por norma, é atribuído às ciências naturais" (J. BLEICHER, Hermenêutica contemporânea, p. 39).
} 
autonomia das ciências do espírito. "Suas reflexões histórico-filosóficas com vistas à fundação das ciências humanas não são, em verdade, conciliáveis com o ponto de partida de sua filosofia da vida", ${ }^{, 11}$ Na formulação diltheyniana de que a vida conduz à reflexão, a reflexão conduz à dúvida, e a vida só pode resistir a essa última, verifica-se que apenas do ponto de vista das dimensões da vida humana torna-se possível a conquista e a validade do saber. O problema é que - observa Gadamer -, mesmo submetendo à reflexão a totalidade da vida real - a partir de uma outra ordem de racionalidade -, o que Dilthey entende por saber e reflexão é incompatível com o princípio de imanência do saber à vida. Tal postura reflexiva e dubidativa não é adequada à reflexão do saber espontâneo inerente à vida - e, desse modo, bem mais se aproxima do ideal científico do Iluminismo. Embora haja uma diferença fundamental entre a certeza das ciências, adquirida por meio de uma dúvida metódica, e aquela certeza imediata que se realiza no âmbito da vida, Dilthey não distingue dessa dúvida metódica aquela dúvida que espontaneamente nos invade. Bem como sua investigação em busca das "formas sólidas" - tendência essencial da vida - tem a pretensão de ser atingida muito menos a partir das certezas advindas do âmbito coesivo da vida e muito mais nas certezas obtidas na ciência.

Em uma última consideração a esse respeito, Dilthey, mesmo empenhando-se na tarefa de justificar as ciências humanas, não logra êxito, pois, como nos diz Gadamer, seu esforço

“[...] para compreender as ciências humanas a partir da vida [...] nunca se afinou verdadeiramente com a concepção cartesiana da ciência de que ele não soube desfazer-se. Por mais que quisesse enfatizar as tendências 'contemplativas' da vida mesma, a atração desse algo 'sólido' que a vida comporta, sua concepção de objetividade, que ele reduz à objetividade de 'resultados', permanece ligada a uma origem que é muito diferente da experiência da vida",72.

Seja na retomada da origem das Geisteswissenschaften, seja em seus diferentes níveis de discussão com o historicismo, o que também parece nuclear para o desenvolvimento da problemática central em questão é a própria concepção do método. Mesmo com a efervescência da "escola histórica", sua possibilidade de autoconsciência lógica e o conseqüente esforço de conquista da independência teórico-cognitiva das ciências humanas, a busca exclusiva de um método capaz de salvaguardar uma validade universal e conferir estatuto de cientificidade é, no entender de Gadamer, uma falsa questão.

A dimensão que antecede o uso do método na ciência assume nas reflexões hermenêuticas de Gadamer uma relevante importância. Numa primeira ponderação, seu

\footnotetext{
${ }^{71}$ H.-G. GADAMER, Le problème de la conscience historique, p. 43.

${ }^{72}$ J. BLEICHER, Hermenêutica contemporânea, p. 48.
} 
significado não consiste apenas em buscar, examinar e investigar. O método, ele próprio, não pode ser tomado como um instrumento auxiliar externo que outorga certeza ${ }^{73}$ aos conhecimentos, mas, bem pelo contrário, deve ser pensado para além de sua dimensão instrumental e epistemológica. Dessa forma, a hermenêutica filosófica insiste na necessidade de desconstruir uma racionalidade mais voltada a certezas do que propriamente à verdade. Nesse sentido, a proposta hermenêutica de Gadamer na elaboração de seus fundamentos também busca considerar que o problema da verdade não se constitui, essencialmente, como uma questão de método. Ao contrário, esse grande empenho metodológico pode muitas das vezes comprometer a experiência da verdade enquanto experiência de conhecimento humano.

Não basta que um conhecimento identifique apenas certezas, mas que abra caminho para a determinação da essência da verdade. Além disso, a idéia de um método único, inerente à ciência moderna, corresponde a uma abstração ${ }^{74}$, já que é o próprio objeto que, por sua vez, determina o modo apropriado de sua investigação. Nesse sentido, a matematização, eficiente no âmbito das ciências da natureza, revela-se muito mais inaplicável e ineficiente no âmbito dos fenômenos a que se referem as ciências humanas. Distanciando-se bem mais do campo investigado, possibilita, tão-somente, uma compreensão equivocada daquilo que the é específico por natureza.

Uma vez que, para Gadamer, o problema de autoconcepção das ciências humanas não tem sua legitimidade satisfeita nem de acordo com o paradigma metodológico da ciência moderna, nem com o alcance de um método específico para a consideração de nosso conhecimento histórico - dada sua própria inexistência -, torna-se necessário investigar a partir de quais condições histórico-filosóficas efetivou-se o próprio estatuto científico dessas ciências, bem como de que forma descrever essa classe de saber inerente às ciências humanas.

Desde o início da primeira parte, Gadamer orienta-se pelo discurso do cientista naturalista Hermann Helmholtz ${ }^{75}$. Tal inspiração segue-se não somente como simples

\footnotetext{
${ }^{73}$ Ao tematizar a relação entre filosofia e ciência, Gadamer refere-se à situação de carência de legitimação em que a filosofia encontra-se desde a época moderna e, mais precisamente, desde o século XVII. Surge, a partir de então, uma nova idéia de ciência e de método, desenvolvida primeiramente por Galileu e fundamentada filosoficamente por Descartes. "Foi, especialmente, a idéia de método, ou seja, o assegurar a via do conhecimento por meio do ideal superior de certeza, o que deu validez a um novo conceito de unidade de saber e conhecimento [...]" (H.-G. GADAMER, "Filosofia ou teoria da ciência?", in: A razão na época da ciência, p. 92).

${ }_{74}$ "Em Aristóteles, por exemplo, a idéia de um método único, que se possa determinar antes mesmo de investigar a coisa, constitui uma perigosa abstração; é o próprio objeto que deve determinar o método apropriado de investigá-lo" (H.-G. GADAMER, Le problème de la conscience historique, p. 29).

${ }^{75}$ Gadamer refere-se aqui ao famoso discurso feito por Helmholtz em 1862, cujo título, no original, é "Über das Verhältnis der Naturwissenschaften zur Gesamtheit der Wissenschaften".
} 
ilustração acerca da problemática metodológica sobre a natureza das ciências, mas sim pelo caráter de extrema significação atribuído às ciências humanas, haja vista as condições sob as quais se encontravam, e também pela diferenciação lógico-metodológica que caracteriza a relação entre esses dois domínios científicos. O método indutivo está na base de ambas as ciências, entretanto, enquanto as ciências naturais caracterizam-se pela indução lógica, base de toda ciência experimental, as ciências humanas produzem seus conhecimentos a partir de “condições psicológicas especiais" exigindo uma espécie de senso de tato. Trata-se aqui da indução instintiva, artística, que brota de aptidões especiais, uma espécie de sensibilidade instintiva, como memória e autoridade. Para esta última, no entanto, não existem regras.

Seguindo a orientação formulada por Helmholtz, a legitimidade das ciências do espírito, observa Gadamer, parecia estar bem mais relacionada com o emprego de tato do que com uma peculiaridade metodológica. Aqui parece estar em jogo algo muito distinto, a partir do qual Helmholtz prefere falar em "indução artística", ou mesmo de tato, dificilmente apreendido com a ajuda de métodos. Não é pela busca obsessiva de um método específico, mas conduzindo-se muito mais por algo de caráter não metódico, como o tato, que essa espécie de conhecimento adquire sua marca de cientificidade.

A assimilação desse ponto de vista mostra-se-nos bastante relevante, já que o fundamento de sua argumentação parece adequar-se à trilha inicial e específica de desenvolvimento da obra. É partindo da análise sobre a natureza da experiência e, conseqüentemente, sobre o caráter de verdade da experiência da arte que Gadamer investiga as condições de possibilidade de um estatuto gnosiológico das ciências humanas, ou mesmo de sua independência teorético-cognitiva. Além disso, também nos incita a indagar por que estaria nas condições intuitivas da sensibilidade e da experiência artística o fundamento determinante que confere autonomia às ciências humanas. Como nos diz Grondin, referindose a Verdade e método: "Se é verdade que se entendeu um livro, quando se pode aduzir a questão à qual ele é resposta, então foi o perguntar sem reservas de Helmholtz pelo modo do conhecimento das ciências do espírito que deu o impulso originário a Verdade e método" ${ }^{, 76}$.

Sustentar uma crítica fundamental à obsessiva necessidade metodológica reivindicada pelos cientistas do espírito impulsiona Gadamer a desenvolver uma investigação hermenêutica capaz de fazer jus a essa forma específica de conhecimento. No entanto, o que se torna relevante como ponto de partida para compreender seu caráter científico já não é mais a idéia de ciência moderna e o parâmetro da lógica indutiva, nem tampouco o projeto

${ }^{76}$ J. GRONDIN, Introdução à hermenêutica filosófica, p. 182. 
historicista da hermenêutica de Dilthey. O problema de método que se punha desde meados do século XIX conduziu ao específico problema das ciências humanas, uma vez afetadas por uma inferioridade metodológica em face das ciências naturais. Desse modo, ou se acatavam plenamente os métodos sugeridos com base no êxito das ciências naturais e que, por sua vez, negariam uma diferenciação entre essas duas esferas científicas, em benefício de uma unidade positivista; ou bem as ciências humanas desenvolviam sua metodologia própria e autônoma, tentativa essa muito bem representada pelo pensamento de Dilthey e sua escola. Em suas reflexões, Gadamer, no entanto, ressalta que, embora Dilthey tenha desenvolvido uma peculiar sensibilidade hermenêutica para sustentar a autonomia dessas ciências, a partir de suas formulações ainda se mantém a pergunta: será uma pressuposição metodológica sempre ofuscada pelo modelo das ciências exatas a alternativa certa para a compreensão das ciências humanas ou mesmo o caminho certo para uma hermenêutica das ciências humanas?

Compreender aqui tem na base de seu significado o sentido de um votar-se à tradição, um recordar voltado, fundamentalmente, às "condições",77 (anderen Bedingungen) sob as quais se formaram e se encontravam as ciências humanas (Geisteswissenschaften). Afirma Gadamer: "O que faz das ciências humanas ciência é mais compreensível com base na tradição do conceito de formação do que da idéia de método da ciência moderna" ${ }^{\text {"78 }}$. No propósito de entender a pretensão de verdade e o modo de conhecimento das ciências humanas, o mais óbvio para Gadamer torna-se um recorrer às tradições do humanismo.

Trata-se de um recurso à tradição humanista, no sentido de reabilitar os chamados “conceitos-guia humanísticos". É, pois, com base na tradição do conceito de formação cultural, abrindo o "caminho de regresso à tradição" que o caráter de cientificidade das ciências humanas deve ser compreendido e investigado.

O que justifica esse procedimento é a própria tese de que nessa tradição foram formados conceitos cuja resistência contra as exigências da ciência moderna viabiliza, em contrapartida, a possibilidade de as ciências humanas justificarem sua pretensão teoréticocognitiva. Nas palavras de Gadamer: "[...] é da sobrevivência do pensamento de formação humanística que as ciências filosóficas do século XIX extraem sua vida particular [...]"79 . Este retorno à tradição implica tanto identificar as dificuldades que resultam da aplicação do

\footnotetext{
77 "Mas certamente pode-se indagar, como Helmholtz, quanto significa aqui o método, e se as outras condições sob as quais se encontram as ciências do espírito não serão, para sua forma de trabalhar, quem sabe muito mais importantes do que a lógica indutiva" (H.-G. GADAMER, WM, I, p. 13).

${ }^{78}$ Id., ibid., p. 23.

${ }^{79}$ Id., ibid., p. 24.
} 
conceito de método moderno às ciências humanas, quanto investigar como, mediante a atrofia dos conceitos formados na tradição humanista, o caráter de verdade dessas mesmas ciências submeteu-se ao padrão metódico da ciência moderna, cuja natureza lhe era estranha. Eis a fundamentação teórico-epistemológica que, na reflexão de Gadamer, proporciona não só a autodeterminação das modernas ciências humanas do século XIX, como também amplia o esclarecimento sobre a relação entre conhecimento e verdade.

Sob um alicerce filológico-histórico, num exercício de exímia erudição, Gadamer desenvolve uma análise sobre esses conceitos-guia, atentando ao modo pelo qual estes atuaram negativamente nas ciências do espírito, ou mesmo ao fato de que essa tradição do humanismo perdeu para nós seu aspecto de obviedade. É bem verdade que aqui não pretendemos analisar esse estudo pormenorizado sobre a tradição desses conceitos como condição fundamental para compreender a índole moderna das ciências humanas do século XIX. Restringir-nos-emos, tão-somente, ao caráter específico de estetização dos conceitos básicos do humanismo, na medida em que o significado e o alcance de suas determinações justificam o cunho de cientificidade dessas ciências, bem como a necessidade de uma reconsideração ontológica sobre o fenômeno da arte. A respeito disso, Grondin, leitor de Gadamer, nos diz: a decadência da tradição humanística efetuou-se "[...] pela perniciosa estetização dos conceitos básicos do humanismo, sobretudo o do juízo e o do gosto, aos quais, anteriormente, cabia a função de conhecimento" ${ }^{, 80}$.

Sendo o objeto das ciências humanas (Geisteswissenschaften) a existência moral e histórica do homem, em suas distintas configurações, estas são decisivamente determinadas pelo conceitos humanistas de sensus communis, juizo, gosto. Entretanto, observa Gadamer, para sua moderna autodeterminação no século XIX, a filosofia da época de Kant e Goethe foi bem mais decisiva em sua influência que a tradição moral a qual pertenciam Vico ${ }^{81}$ e Shaftesbury. Em vez de um senso que, inerente a todos os homens, baseia-se na universalidade concreta, institui a comunidade e, enquanto qualidade geral do cidadão, constitui uma decisiva importância para a vida, assimilou-se um conceito de "sensus communis" desprovido de sua especificidade crítica e totalmente despolitizado.

A partir da Aufklärung alemã, sua correspondência refere-se apenas a uma faculdade teórico-reflexiva, levando, dessa forma, não só a um esvaziamento e intelectualização de

\footnotetext{
${ }^{80}$ J. GRONDIN, Introdução à hermenêutica filosófica, p. 184.

${ }^{81}$ Para Gadamer, o conceito de "sensus communis" em meio a uma tradição humanística advinda da Antiguidade assume em Vico um importante ponto de referência.
} 
conteúdo, como a uma conseqüente estetização. Ao afirmar o sensus communis como sentido público, Kant também alinha essa forma reflexiva de juízo com o gosto - o gosto como uma espécie de sensus communis. Desse modo, este conceito adquire uma função negativa, se comparado à sua tradição.

O conceito de juízo, por sua vez, é visto, na Alemanha do século XVIII, em uma estreita relação com o conceito de sensus communis. Isto é, a compreensão comum é caracterizada decisivamente pelo juízo, iudicium - inerente a todo ser humano -, a partir do qual podemos aplicar corretamente o que aprendemos e sabemos. A tentativa, todavia, de reproduzir o conceito de iudicium, virtude espiritual fundamental, também acarretou limitações em sua própria significação. Se, enquanto faculdade de avaliação e escolha, o juízo não se reduzia ao intelecto, posteriormente sua atividade de fazer de nossas representações os objetos de nosso pensamento - subsumir o particular no universal - tornou-se uma operação intelectual de síntese.

Ao compreender o juízo apenas como uma mais baixa faculdade de conhecimento, a filosofia da Aufklärung alemã acaba conferindo, nessa sua consideração, um significado especial à estética. Lembrado por Gadamer, Baumgarten, em sua Metafisica, nos ensina: "O que o juízo reconhece é o sensorial-individual, o singular, e o que ele julga é sua perfeição ou imperfeição" ${ }^{~}{ }^{2}$. Tem-se então o que Baumgarten denomina julgamento sensível, dependente apenas das representações dos objetos - o gosto em seu sentido amplo -, e o julgamento intelectual, a arte de formar gosto e de expor o julgamento pelos sentidos, posteriormente chamado por Kant de gosto - o julgamento estético.

Da mesma forma que Gadamer observa o estreitamento do conceito de sensus communis e juízo, em decorrência do efeito de sua subjetivação a partir da Aufklärung alemã, essa modificação também é verificada no próprio conceito de gosto (Geschmacks). Em sua amplitude originária, trata-se de um conceito que desfrutou de uma significação mais moral do que estética. O gosto, o gosto sensível, conforme pensava Balthasar Gracián, lembra Gadamer, já contém o ponto de partida da diferenciação que se realiza no julgamento espiritual das coisas, e dele também procede a formação da cultura. Para o humanismo representava uma forma de conhecimento ou mesmo um sentido universal, cuja presença na formação, embora não fosse possível ensinar-se, é necessária, em benefício da convivência humana. Entretanto, o gosto não é apenas o ideal de uma sociedade bem instruída, ele, antes

\footnotetext{
${ }^{82}$ H.-G. GADAMER, $W M$, I, p. 36.
} 
mesmo que isso, é o signo desse "ideal de bom gosto", aquilo que se denomina "boa sociedade".

Tal reconhecimento dá-se muito menos por uma questão de status ou mesmo de nascimento, mas, mais precisamente, pela comunhão de seus julgamentos. Depende, pois, do elevar-se da privacidade dos interesses para a exigência de um julgamento. E, uma vez correspondendo a uma capacidade de manter-se à distância das preferências privadas, constitui um fenômeno social por excelência; nesse sentido, bem mais vinculado ao aspecto concreto em que ele se realiza do que a regras e a conceitos.

Em contrapartida, tomando-se o gosto como cânone para julgar-se os objetos do sentimento, no século XVIII, esse conceito torna-se faculdade do sentimento, à qual foi atribuída a atividade própria da estética. Refere-se, a partir de então, a uma faculdade de julgar o que é universalmente comunicável, embora de forma não conceitual. O gosto limitase ao julgamento estético do belo.

No âmbito dessas considerações, a argumentação de Gadamer parte do fato de que do estreitamento ou limitação dos conceitos-guia, anteriormente mencionados, seguem-se não apenas a decadência da tradição humanista, mas a conseqüente subordinação das ciências humanas ao ideal de método da ciência moderna. Mediante a perniciosa estetização desses conceitos - sobretudo dos conceitos de juízo e gosto -, desqualificando-os de sua função cognitiva, a conquista de autonomia das ciências humanas reorienta seu destino. E o processo dessa modificação consolida-se com o surgimento impactante e as ressonâncias do criticismo kantiano.

O impacto que as indagações transcendentais e a Crítica da faculdade de julgar de Kant provocaram no cerne das ciências humanas (Geisteswissenschaften) ocasiona, para essa espécie de conhecimento, perdas de longo alcance e de caráter irreparável. Mediante o abandono da orientação de tradição humanística, âmbito no qual as ciências do espírito podiam reconhecer-se, assimila-se o caminho da estetização e da subjetivação do juízo. Perdese com isso "[...] aquilo de que viviam os estudos filológico-históricos e donde, exclusivamente, poderiam ter alcançado sua total auto-evidência quando, sob a denominação de 'ciências humanas', queriam fundamentar-se metodicamente ao lado das ciências da natureza" ${ }^{\natural 3}$. A originalidade metódica dessas ciências em sua reivindicação específica de verdade perde sua legitimação.

\footnotetext{
${ }^{83}$ Id., ibid., p. 46.
} 
Conforme já foi mencionado anteriormente, desde o início de Verdade e método parece estar bastante claro que um de seus propósitos aponta para uma crítica ao cientificismo e ao metodologismo modernos, na tentativa de ultrapassar a noção de conhecimento delimitada pelo método científico positivo, característico da ciência moderna e do ideal científico da filosofia das Luzes. Nesse intento, porém, o recurso da tradição humanista como via para o reconhecimento da própria origem, desenvolvimento e também fundamento das ciências humanas, tornou-se insatisfatório em seu mérito, tendo em vista as determinações conceituais e transcendentais do pensamento kantiano. Portanto, faz-se necessário determonos um pouco mais atentamente nessa idéia de subjetivação no horizonte de suas conseqüências.

A esse respeito, diz-nos Gadamer:

“Se fixarmos os olhos no papel que a crítica do juízo de Kant desempenha no âmbito da história das ciências do espírito, teremos de dizer que sua fundamentação transcendental e filosófica da estética foi rica em conseqüências para ambos os lados e que representa nisso uma época. Representa a ruptura de uma tradição, mas, ao mesmo tempo, o preâmbulo de um novo desenvolvimento. Limitou o conceito de gosto ao campo em que podia reivindicar, como um princípio próprio do juízo, validade autônoma e independente - e, no lado oposto, restringiu com isso o conceito de conhecimento à utilização teórica e prática da razão. A intenção transcendental que o guiava encontrou sua realização no restrito fenômeno do julgamento sobre o belo (e o sublime) e desterrou do centro da filosofia o conceito mais universal da experiência do gosto e a atividade do juízo estético no âmbito do direito e dos costumes ${ }^{, 84}$.

O giro empreendido pelo pensamento kantiano constitui uma mudança decisiva. Ressalte-se, todavia, que também para Kant a tradição humanista representava uma grande evidência, seja quando se refere na Crítica da razão pura à falta de juízo como uma deficiência sem remédio, seja quando na Crítica da faculdade de julgar atribui ao juízo estético um significado de caráter moral. Aos olhos de Gadamer, porém, ao longo da exposição de seu pensamento, o significado nuclear da tradição humanista perdeu-se. $\mathrm{Na}$ primeira das críticas, a de 1791, a questão dominante é a possibilidade da metafísica como ciência. A metafísica é uma espécie de conhecimento que, embora a razão não possa ignorar, ultrapassa seus poderes, inerentes aos quais acham-se perplexidades e contradições. Submetida ao tribunal da crítica, a metafísica, outrora rainha das ciências, é condenada a examinar seus limites e redefinir seu âmbito e propósitos. É bem verdade que Kant, quando

${ }^{84}$ Id., ibid 
indaga acerca da possibilidade da metafísica como ciência, tem como fundamento a concepção newtoniana sobre ciência, de modo que a condenação da metafísica dogmática e essa referência a Newton são suficientes para fazer deste filósofo alemão um partidário das ciências naturais como fonte de um conhecimento verdadeiro.

Restringir o conceito de conhecimento teórico ao domínio da ciência da natureza significa, na ponderação kantiana, que para conhecer um objeto devemos ser capazes de provar sua possibilidade, a partir de sua efetividade, conforme atestada pela experiência, ou $a$ priori por meio da razão. O conhecimento refere-se a uma representação a partir da qual os objetos dados na sensibilidade são pensados pelas categorias do entendimento, e por suas regras gerais e necessárias. Eis o âmbito particular em que se torna possível a experiência de verdade, que é, por isso, também restrito ao domínio da natureza. Como conseqüência da refundamentação transcendental da estética kantiana, reflete Gadamer: "A subjetivação radical [...] marcou verdadeiramente uma época. Ao desacreditar qualquer outro conhecimento teórico que não fosse o da ciência da natureza, forçou a autodeterminação das ciências do espírito a apoiar-se na doutrina de método das ciências da natureza [...] [levando em conta] como dispositivo secundário o momento artístico, o sentimento e a 'empatia"»85.

O que conduz Gadamer a deslocar sua reflexão sobre a via da arte é precisamente o desafio imposto pela diretriz subjetiva do pensamento kantiano que limita o fenômeno da compreensão conceitual às regras da razão pura, desautorizando às demais experiências humanas o testemunho da verdade, até mesmo à experiência estética. Kant, ao legitimar a generalidade subjetiva do gosto estético, justificando-a transcendentalmente, funda a autonomia da consciência estética. A análise hermenêutica sobre "a subjetivação da estética pela crítica kantiana" desenvolve seu prolongamento, nessa reflexão hermenêutica, sob a forma específica de uma "crítica à consciência estética". Seu empenho é identificar, nessa formulação teórico-filosófica, uma atitude complementar do cientificismo moderno.

Por outro lado, no tocante às ciências humanas, estas se vêem diretamente afetadas em decorrência da evolução do pensamento kantiano. Diante do êxito e da glória das ciências naturais, as ciências humanas constituem tão-somente um campo de saber carente de satisfação rigorosa às normas metodológicas da ciência, em seu sentido estrito. Por isso, elas acabam integrando-se a um saber não metódico pertinente à tradição humanista e carente de legitimação enquanto conhecimento verdadeiro. "O saber do gosto não é, evidentemente, uma

\footnotetext{
${ }^{85}$ Id.,ibid., p. 47. Gadamer complementa essa afirmação dizendo que Kant, na formulação de sua Crítica do juizo, é um bom exemplo de atuação do pensamento tal como definido pelo cientista Helmholtz.
} 
ciência, por mais que contribua à formação da capacidade do juízo e do sensus communis. $\mathrm{O}$ que é então? A resposta a que se abre caminho em Kant, e que sua posteridade radicalizará, assim diz: é algo estético. A cultura do gosto, depois de Kant, converte-se naquilo que tem sido em boa parte até hoje: um assunto puramente estético. Com isso, foi desaparecendo cada vez mais o sentido cognitivo da cultura humanística e também da arte" ${ }^{\circledR 6}$.

Desse modo, conferir cientificidade aos conhecimentos oriundos do âmbito da cultura é inserir-se na tendência de obedecer ao rigor metodológico que garantiu o êxito das ciências naturais. Resta apenas buscar análises metodológicas também para as ciências humanas; de modo que a evolução desse processo é diretamente proporcional ao distanciamento dessas ciências do cultivo de sua tradição humanística. É precisamente isto que, para Gadamer, reveste-se de uma notória importância, impossível de ser superestimada.

Por isso, é com base na compreensão desse caminho da estetização empreendido pelo pensamento kantiano, na medida em que confere à estética uma fundamentação transcendental, que não apenas a análise sobre a autoconcepção das ciências humanas ganha densidade, como também a reflexão sobre a arte enquanto esfera de conhecimento emerge como fundamento e justificativa hermenêutica necessária.

\subsection{A fundamentação da estética kantiana e a crítica da consciência estética}

A insuficiência da auto-interpretação das ciências humanas, tendo em vista sua subordinação ao método das ciências da natureza, resulta para Gadamer em uma análise fundamental, cujo desdobramento culmina em uma reflexão criteriosa sobre a autonomia do estético. O caráter transcendental do juízo estético na teoria kantiana não apenas impôs uma delimitação ao conhecimento conceitual, como também o restringiu em sua função aos fenômenos do belo e da arte. Desse modo, a hermenêutica filosófica, ao buscar reconquistar uma compreensão mais adequada da espécie de conhecimento acionada pelas ciências humanas, abre também um caminho expresso tanto para repensarmos a constituição da estética, considerando a problemática de sua criação, quanto para a reconsideração da questão da arte e verdade.

\footnotetext{
${ }^{86}$ J. GRONDIN, Introducción a Gadamer, p. 54.
} 
Essa análise, Gadamer desenvolve-a sob a denominação de uma crítica à subjetivação da estética pelo pensamento kantiano, ou, mais precisamente, de uma "crítica à abstração da consciência estética" (Kritik der Abstraktion des ästhetischen Bewußtseins), cujo propósito consiste em mostrar as conseqüências da subjetividade como princípio a priori da consciência estética, deslocando o estético a um domínio sempre desprovido de valor cognitivo ${ }^{87}$.

A questão específica que orienta a análise gadameriana é a seguinte: por que a função transcendental conferida ao juízo estético por Kant é suficiente para destituí-lo de sua função conceitual e de verdade? Tendo em vista a necessidade de compreendermos a subjetivação da estética pela crítica kantiana, qual o alcance de seu desdobramento?

Embora, no momento, não tenhamos a predisposição de ocuparmo-nos da analítica kantiana no horizonte de seus pormenores, torna-se necessário, todavia, entender o caráter da fundamentação kantiana da estética, tendo em vista a pretensão distinta do juízo estético na significação de sua autonomia.

Como normalmente é considerado, a "estética" ganha sua legitimação enquanto universalidade subjetiva do gosto no pensamento moderno junto ao criticismo filosófico kantiano. Da mesma forma que seu pensamento eleva para a posteridade o modelo científico das ciências naturais a uma categoria de norma tanto absoluta quanto exclusiva; também confere à estética (Crítica da faculdade de julgar, 1790) uma esfera de autonomia, para além do conhecimento (Crítica da razão pura, 1781) e da moral (Crítica da razão prática, 1788).

Na Crítica da razão pura, sob a expressão "estética transcendental", Kant aborda a estética como conhecimento das condições a priori da receptividade cognitiva humana, analisando a esfera da sensibilidade enquanto condição de possibilidade do conhecimento, a partir das condições fundamentais - intuições puras - de espaço e tempo. Fundamenta-se, filosoficamente, a autonomia radical do sensível com relação ao inteligível. Em sua Crítica da faculdade de julgar, Kant faz uso da palavra "estética" referindo-a, agora, a uma forma específica de julgamento. A possibilidade do juízo estético é investigada na perspectiva de uma legitimação a priori que lhe permita ultrapassar as diferenciações e relativismos do

\footnotetext{
${ }^{87}$ Conforme assinala Grondin, a crítica à autonomia da consciência estética desenvolvida por Gadamer em Verdade e método parece vacilar um pouco se considerarmos algumas reflexões posteriores suas. Em "Intuição e intuitividade" (Anschauung und Anschaulichkeit, in: GW, 8, p. 143-55), de 1980, Gadamer manifesta-se muito simpático ao caráter moral da experiência estética proferido por Kant, atribuindo aos seus sucessores o isolamento da consciência estética (Cf. J. GRONDIN, "Gadamer's Aesthetics. The Overcoming of Aesthetic Consciousness and the Hermeneutical Truth of Art", in: Encyclopedia of Aesthetics, Vol. 2, p. 267-71).
} 
gosto. De fato, Kant entende o estético sobretudo como juízo estético, cuja significação é inerente ao âmbito da crítica do gosto, com relevância tanto moral quanto política.

As questões sobre o gosto sendo discutidas pela argumentação e demonstração, ao mesmo tempo não há uma universalidade empírica que determine o bom gosto e à qual nos submetamos cegamente. Se por ele nos orientamos, não é por imitação, mas pelo caráter preferencial que seu modelo pode representar para nós. Quando, todavia, trata-se de um julgamento estético, a exigência de uma norma supra-empírica é privilegiada, em detrimento de uma decisão por uma preferência particular. A Crítica da faculdade de julgar de Kant resulta da intuição de que, além do julgamento crítico das pessoas ao qual o gosto, em sua universalidade empírica, subordina-se, subsiste um momento apriorístico que o ultrapassa. Por isso é que se constitui como "crítica da crítica, isto é, indaga a respeito dos direitos de um tal comportamento crítico sobre questões de gosto" ${ }^{88}$. Eis o a priori kantiano que, ao mesmo tempo em que justifica a possibilidade da crítica, reivindica a universalidade e nega ao gosto qualquer significado de conhecimento. O gosto torna-se um "gosto de reflexão", já que nele nada se reconhece do gênero de existência dos objetos. Essa fundamentação crítica do juízo do gosto, mesmo contemplando o fenômeno, tanto em sua dimensão empírica quanto em sua reivindicação apriorística, não confere a essa experiência - o gosto - qualquer significado cognoscitivo. Nesse sentido, ao se dizer que algo é belo, renuncia-se a qualquer possibilidade de conhecimento sobre o objeto. Trata-se apenas de um princípio subjetivo, da reação subjetiva de um sentimento a priori de prazer.

$\mathrm{Na}$ obra kantiana é fundamental atentar para o fato de que estamos diante de um pensamento fundamental sobre a noção de sujeito; um sujeito que é essencialmente reflexão, o que se encontra já implicado na diferença entre juízo determinante e juízo reflexionante. Trata-se de uma distinção em que se baseia toda a formulação teórica estética, desenvolvida na terceira Crítica. Enquanto uma faculdade legislante a priori, “a faculdade do juízo em geral é a faculdade de pensar o particular como contido no universal. No caso de este (a regra, o princípio, a lei) ser dado, a faculdade do juízo que nele subsume o particular, é determinante [...] Porém, se só o particular for dado, para o qual ela deve encontrar o universal, então a faculdade do juízo é simplesmente reflexiva" ${ }^{99}$. É, pois, nesse sentido que a terceira Crítica propõe-se ao esclarecimento sobre a atividade da faculdade de julgar da subjetividade no exercício de sua função originária de subsumir. Em sua determinação quando os termos do

\footnotetext{
${ }^{88}$ H.-G. GADAMER, $W M$, I, p. 48.

${ }^{89}$ I. KANT, Crítica da faculdade de julgar, p. 23.
} 
juízo são objetivamente determináveis, ou seja, quando subsumem sob leis ou conceitos dados como princípios, o juízo é objetivo, e sua atividade é determinante. Aqui podem ser muito bem exemplificados os juízos teóricos, os juízos do conhecimento, “[...] nos quais as leis do entendimento são as leis e os conceitos dados que subsumem os particulares do múltiplo da intuição através do esquematismo e dos princípios" ${ }^{\text {"90 }}$. Por outro lado, na atividade de reflexão - do particular ao universal - o geral ou universal não é anterior à reflexão, já que só por meio de sua atividade é então dado; opondo-se, assim, ao juízo determinante, que é uma aplicação do universal. Embora o geral não seja dado como conceito ou leis determinadas, desde o início, há um princípio regulador que apenas a faculdade do juízo reflexivo pode dar a si mesma para o cumprimento de sua atividade: conformidade a fins (Zweckmässigkeit). O universal é então tomado não como conceito, mas como Idéia, no sentido de possibilitar ao real sua conformação ao lógico.

Desse modo, na faculdade de julgar a representação é destituída de uma referência objetiva, pois se trata de uma faculdade de prazer ou desprazer referida apenas ao sujeito no âmbito de seu sentimento. Portanto, encontramo-nos aqui no domínio da natureza estética das representações - "representação estética da conformidade a fins" ${ }^{\text {"91 }}$-, ou seja, uma representação meramente subjetiva que, não nos possibilitando uma parte do conhecimento, conduz-nos a um sentimento de prazer ou desprazer. Se esse sentimento decorre apenas da apreensão da forma do objeto, sem que sua representação ligue-se a um conceito desse objeto, mas unicamente ao sujeito, isso significa que o prazer exprime tão-somente a adequação desse objeto às faculdades do conhecimento sob uma forma especial.

$\mathrm{Na}$ faculdade de juízo reflexiva, a conformidade a fins do objeto é inteiramente subjetiva, e o juízo que daí resulta denomina-se juízo de gosto, ou estético. Isto decorre de um sentimento despertado por uma relação de conveniência que a representação do objeto estabelece com nossas faculdades cognoscitivas. A justificação transcendental do juízo de gosto, válida tanto para o belo natural quanto para o belo artístico, corresponde àquilo que Kant nomeia jogo livre da força da imaginação e do entendimento, fundamento do sentimento de prazer diante do objeto. O caráter de validade universal do juízo de gosto advém, precisamente, do fato de que essa relação de conveniência subjetiva, que possibilita a adequação desse livre jogo entre as faculdades humanas, realiza-se em todos os seres

\footnotetext{
${ }^{90}$ H. CAYGILL, Dicionário Kant, p. 209.

${ }^{91}$ I. KANT, Crítica da faculdade de julgar, p. 33.
} 
humanos e pode ser universalmente transmitida ${ }^{92}$. Na reflexão kantiana o gosto não mais constitui uma mera "cognitio sensitiva", mas sim um "gosto de reflexão",93, o " verdadeiro senso comum". A pretensão de sua validez universal, no entanto, não pode ser qualificada de objetiva, já que a validez do juízo de gosto não pode ser a mesma da ciência. Se o caráter de universalidade objetiva está reservado apenas à ciência, a esse âmbito de validez universal corresponde, como diz Kant no $\S 6$ da Terceira Crítica, uma "universalidade subjetiva"; uma universalidade que apenas afeta o jogo de nossas faculdades do conhecimento.

Essa concepção concentra, assim, um duplo caráter: a universalidade, referente ao jogo livre das faculdades e o caráter da comunitariedade. Ou seja, o gosto é uma espécie de senso comum, em seu significado de "sensus communis", sentimento público enquanto "faculdade de julgar aquilo que se torna universalmente comunicável, sem a mediação de um conceito",94. Ademais, o juízo do gosto só é universal porque se baseia na comunicabilidade do sentimento com os outros; é o prazer na comunicação intersubjetiva que fundamenta a comunhão e institui a comunidade. Assim, a diversidade do conteúdo do gosto é deixada de lado tendo em vista sua função transcendental, o princípio próprio que rege o juízo de gosto ou estético. Como observa Gadamer, na experiência estética o gosto, além de constituir um aspecto nivelador, mostra-se em seu caráter comunicativo; daí que torná-lo restrito ao âmbito individual revela-se algo, notoriamente, sem sentido, no campo da estética. Sua validade advém da própria independência do fato estético diante da finalidade prática e do conceito teórico. Aquele que expressa um juízo de gosto e afirma que algo é belo não manifesta apenas uma satisfação particular, porém, sobretudo pretende a aprovação de alguém; sua validade não é meramente subjetiva, já que não basta que apenas lhe agrade. O juízo estético corresponde, pois, a uma "complacência [Wohlgefallen] desinteressada" 95 . O juízo de gosto

\footnotetext{
${ }^{92}$ Como nos diz Gadamer, aí estaria uma "indicação da determinação supra-sensível da humanidade na totalidade da natureza" (H.-G. GADAMER, Zur Fragwürdigkeit des ästhetischen Bewußtseins, in: GW, 8, p. 9).

${ }_{93}$ Do ponto de vista da crítica gadameriana ao criticismo kantiano, convém salientar que, se, por um lado, o juízo estético pela modalidade da reflexão amplia um grau de complexidade, ultrapassando os limites do juízo determinante, por outro, ele consigna a esfera da estética ao âmbito eminentemente subjetivo, privando-a de constituir-se como experiência de verdade. Além disso, como afirma Grondin, comentando Makkreel, a partir de sua obra Imagination and Interpretation in Kant. The Hermeneutical Import of the "Critique of Judgement": "Makkreel havia mostrado que a distinção entre o entender das ciências humanas e as explicações dadas pelas ciências naturais derivava objetivamente da distinção kantiana entre juízos determinantes e juízos reflexionantes, exposta na Terceira Crítica: [...] os juízos reflexionantes procedem mais hermeneuticamente tratando de integrar o dado particularmente em um marco de significação mais amplo [...] As metodologias do século XIX não o observaram, porque Kant seguiu sendo para eles o autor da Crítica da razão pura, lida como um tratado sobre o método das ciências naturais" (J. GRONDIN, Introducción a Gadamer, p. 54).

${ }^{94}$ I. KANT, Crítica da faculdade de julgar, $§ 40$.

${ }^{95}$ Aqui adotamos "complacência" como correspondente na língua portuguesa do termo Wohlgefallen, de acordo com a tradução feita da Crítica da faculdade de julgar por Valério Rohden e António Marques. Sobre a referida tradução, ressalte-se a Nota 22 do $§ 2$ da referida obra. Diz Kant: "Gosto é a faculdade de ajuizamento de um
} 
puro ou juízo do belo é, pois, aquele que não pode estar mesclado de nenhum interesse, logo destituído de qualquer finalidade prática ou mesmo interesse teórico; "[...] o gosto pelo belo é uma complacência desinteressada e livre; pois nenhum interesse, quer o dos sentidos, quer o da razão, arranca aplauso",96.

De qualquer forma, se a fundamentação kantiana da estética não tem como propósito a objetividade das ciências é porque também a sua pretensão é outra, qual seja, assinalar a autonomia do juízo estético ${ }^{97}$.

Em sua discussão com a estética kantiana e tendo em vista seu intento de compreender a autonomia da estética, Gadamer dispensa uma atenção especial a uma questão fundamental para sua compreensão da arte. Trata-se do juízo de gosto "puro" e "intelectualizado" e sua correspondência às concepções de "beleza livre" e "beleza aderente" (Crítica da faculdade de julgar, $\S 6$ ). Temos então a beleza do gosto puro, a beleza livre, aquela que constitui o objeto de um puro juízo de gosto, à qual "não é pressuposto nenhum conceito de qualquer fim,"98 $\mathrm{e}$ na qual não interferem pontos de vista intelectuais ou morais. Representam essa beleza os arabescos, as flores ornamentais, o belo natural livre. Segundo Gadamer, há uma diferença quando Kant fala das belas coisas da natureza e da bela representação da arte. A beleza condicional e não-livre corresponde às representações de "um objeto sob um determinado conceito"; tornando-se sempre necessário uma abstração consciente de um conceito ou finalidade. A beleza aderente enquanto uma classe menos pura da beleza assim é definida porque seu sentido não é puramente estético, uma vez que, "aderente a um conceito (beleza condicionada), é atribuída a objetos que estão sob o conceito de um fim particular"99 está aderia a um conceito. Nesta esfera, encontram-se as coisas da natureza, àquelas que ocorrem ou mesmo foram destinadas para fins humanos, como, por exemplo, o homem, os animais, os prédios Nesse sentido esse tipo de beleza também é representado pelo reino das artes pictóricas, de construção e poética. Se, para Kant, um juízo de gosto referente à beleza livre não pode estar fundamentado na idéia de um "fim", é porque de alguma forma essa referência comprometeria a pureza desse juízo. Para Gadamer, a distinção entre beleza livre e beleza aderente acarreta no pensamento estético kantiano a pretensão de estabelecer a pureza estética do juízo de gosto, de modo que "a determinação do fim significa uma limitação para o prazer

objeto ou de um modo de representação mediante uma complacência ou descomplacência independente de todo interesse. O objeto de uma tal complacência chama-se belo" (id., ibid.,, p. 55; grifos presentes no original).

${ }^{96}$ Id., ibid.

${ }^{97}$ Também a esse respeito Gadamer desenvolve considerações sobre a teoria estética kantiana na $1^{\mathrm{a}}$ parte da obra Atualidade do belo: A arte como jogo, símbolo e festa.

${ }^{98}$ I. KANT, Crítica da faculdade de julgar, p. 75.

${ }^{99}$ Id.,ibid 
estético" ${ }^{100}$. Trata-se de uma teoria cujo caráter distintivo é também seu propósito de cercear o juízo estético, prescrevendo o caráter de sua autonomia diante do conhecimento e da moral; privando-lhe de toda referência ao ser e ao conhecer. Aos olhos de Gadamer, o que se torna decisivo nessa concepção kantiana é que não é do ponto de vista da fundamentação do "juízo de gosto puro" que se dá o reconhecimento da arte.

O ideal de beleza que, por sua vez, não deriva de nenhuma regra de gosto objetiva, todavia, nem de qualquer determinação conceitual só existe com relação à figura humana, ou seja, na "expressão do ético". Conforme assinalamos anteriormente, para Kant, sendo o sentimento subjetivo o fundamento determinante de o juízo estético identificar um princípio que forneça critério universal do belo, o juízo estético proveniente do sujeito torna-se uma tarefa sem sentido. $\mathrm{O}$ caráter de universalidade provém da comunicabilidade desse sentimento, dessa unanimidade no ajuizamento das formas sob as quais os objetos são captados. Isso faz do gosto uma faculdade própria, cujo modelo mais elevado constitui uma simples idéia que cada um tem de produzir de si; uma idéia da razão que não pode ser determinada mediante conceitos, mas que pode ser buscada enquanto ideal - a representação de um ente individual como adequado à idéia -, o ideal de beleza a ser produzido em nós sob a forma de apresentação individual. $\mathrm{O}$ homem assim o representa porque apenas ele tem o fim de sua existência em si mesmo, podendo ele próprio determinar-se segundo a sua razão. Mas, se é só na figura humana que o ideal de beleza existe, este se determina mediante a expressão visível das idéias morais.

Ora, embora Gadamer reconheça que é a partir da doutrina do ideal da beleza que se torna possível falar da essência da arte, a concepção kantiana da "beleza como símbolo de moralidade" $" 101$ é a idéia mesma de natureza que, enquanto manifestação de sua beleza - o belo natural -, suscita em nós o sentimento do prazer estético a partir do livre jogo de nossas faculdades cognoscitivas. Em sua relação com o belo artístico, a beleza natural, além da vantagem de ser expressão de um juízo estético puro, é também aquela que, de modo imediato, consegue despertar um interesse moral. O belo contemplado pela natureza é, antes de qualquer coisa, produzido por ela. Daí que o interesse pelo belo na natureza desperta em nós um cultivo de sentimento moral ${ }^{102}$. Donde então se segue que, se a teoria estética kantiana

\footnotetext{
${ }^{100}$ H.-G. GADAMER, WM, I, p. 51.

${ }^{101}$ I. Kant, Crítica da faculdade de julgar, p. 195.

102 “[...] o ânimo não pode refletir sobre a beleza da natureza sem se encontrar ao mesmo tempo interessado por ela. Este interesse, porém, é, pela sua afinidade, moral; e aquele que toma um tal interesse pelo belo da natureza somente pode tomá-lo na medida em que já tenha fundado solidamente seu interesse no moralmente-bom [...]
} 
apresenta uma significação moral, é em um sentido estritamente determinado. Tal caráter está diretamente ligado ao significativo interesse pelo belo natural; interesse que é, pois, “"moral por afinidade'. Na medida em que percebe a coincidência não intencional da natureza com o nosso prazer, que é independente de qualquer interesse, e, por conseguinte, uma maravilhosa conveniência [Zweckmässigkeit] da natureza para conosco, indica-nos, como ao fim último da criação, indica a nossa 'determinação moral" ${ }^{\text {"103 }}$. Eis o que também justifica, segundo Kant, a vantagem do belo natural diante do belo na arte ${ }^{104}$. Embora, diferentemente dos objetos naturais, os produtos artísticos estejam limitados a apenas nos agradar, sua linguagem fala-nos significativamente, submetendo nossa capacidade do conhecimento ao espaço lúdico da liberdade.

Se, do ponto de vista geral, a arte é aptidão para fazer algo, para produzir alguma coisa, sua discussão no pensamento kantiano assume um nível de importância, na medida em que essa habilidade humana é diferenciada daquela presente na ciência, já que o seu fazer não compreende um controle determinado do que deve ser feito, nem do seu efeito. Da impossibilidade de prescrever razões e provas para garantir o juízo de gosto, resulta a própria impossibilidade da ciência do belo. A "arte estética" define-se como a arte cuja intenção imediata é atingir o sentimento de prazer. Entre suas modalidades ${ }^{105}$ apresenta-se a arte bela, cujo fim é o prazer não proveniente de uma simples sensação, mas de um prazer de reflexão e que, portanto, aponta para a comunicabilidade universal de um prazer. O belo, seja ele natural ou da arte, remete-se sempre e necessariamente àquilo que nos apraz. Enquanto arte, sua intenção de produzir algo prevê o mesmo sentimento lúdico e de liberdade das faculdades do conhecimento, cujo prazer assentado é livre de conceitos.

Gadamer também reconhece como mérito da teoria estética kantiana o fato de essa reflexão não se limitar ao caráter formal do "juízo do gosto puro", ultrapassando-o em favor do ponto de vista do gênio. Para a fundamentação da arte, Kant prevalece-se, então, do conceito de gênio, essa força da natureza e, ao mesmo tempo, "essa capacidade para a

naquele a quem a beleza da natureza interessa imediatamente temos motivo para supor pelo menos uma disposição para a atitude moral boa" (id., ibid., p. 146-7; grifado no original).

${ }^{103}$ H.-G. GADAMER, WM, I, p. 56.

104 A especulação sobre o caráter a priori que Kant dispensa ao belo constitui a indagação fundamental no desenvolvimento de sua análise. "A interessante importância do belo é que propriamente movimenta a problemática da estética kantiana. Ela é cada vez uma outra, para a natureza e para a arte, e justamente a comparação do belo natural com o belo artificial dá ao problema seu desenvolvimento" (id., ibid., p. 55-6).

${ }^{105}$ Trata-se aqui das "artes agradáveis" - aquelas que têm em vista simplesmente o gozo decorrente do prazer na sensação - e das "artes belas". 
representação das idéias estéticas" ${ }^{, 106}$. Esse conceito corresponde, precisamente, àquilo que há de decisivo na formulação do gosto estético:

“O jogo aliviado das forças do ânimo, a ampliação do sentimento vital que se gera da congruência da forma de imaginação e entendimento e que convida ao repouso ante o belo. O gênio é um modo de manifestação desse espírito vivificador; aquele que cria para além do que é, convencionalmente, regulamentado. Pois em face da rígida regularidade da mestria escolar, o gênio mostra o livre impulso e invenção, com isso, uma originalidade criadora de modelos" $" 107$.

Há, para Gadamer, uma relação mútua entre gosto e gênio. As obras das belas-artes produzidas por um gênio acham-se submetidas ao ponto de vista condutor da beleza. Isso significa que o invento da obra do artista continua vinculado ao espírito, àquele que cria, que julga e que usufrui. Então escreve: "[...] para Kant, o conceito de gênio significa realmente apenas uma complementação daquilo que o faz interessar-se pelo juízo estético, na 'intenção transcendental" "108 . O gênio, assim como suas belas criações, constitui-se como um favor da natureza, que, por sua vez, impõe as regras à produção. Sendo o talento inerente à faculdade produtiva do artista, esta é inata a ele, logo pertencente à natureza. $\mathrm{O}$ gênio tanto não imita $\mathrm{a}$ natureza como sua originalidade e competência não pode de modo algum ser ensinada a outros; não é possível indicar a regra que inspirou a criação do seu produto. Desse modo, a afirmação kantiana de que "as belas-artes são arte do Gênio" implica que, “[...] também para o belo, não existe na arte nenhum outro princípio de julgamento, nenhuma medida de conceito ou de conhecimento, a não ser o da conveniência [Zweckmässigkeit] para o sentimento da liberdade no jogo de nossa capacidade de conhecimento. O belo na natureza ou na arte tem um e mesmo princípio apriorístico que reside na subjetividade" ${ }^{\text {109 }}$.

Nesse sentido, ressalta Gadamer, embora a arte seja tomada como objeto do juízo do gosto, sua crítica, desenvolvida por Kant, não pretende constituir-se como uma filosofia da arte, já que “o conceito de 'juízo estético puro' corresponde tão-somente a uma 'abstração metódica"'. De modo contundente sustenta que essa autonomia de um a priori subjetivo não é suficiente para fundamentar a validade autônoma do fenômeno do belo, sejam quais forem seus campos.

\footnotetext{
${ }^{106}$ Id., ibid., p. 60.

${ }^{107}$ Id., ibid., p. 59

${ }^{108}$ Id., ibid., p. 60

${ }^{109}$ Id., ibid., p. 61.
} 
Na reflexão transcendental filosófica desenvolvida pelos sucessores do pensamento kantiano, Gadamer, no entanto, observa uma espécie de deslocamento do conceito de gosto para o conceito de gênio. Do ponto de vista da arte, o vínculo do conceito de gênio à natureza torna-o mais abrangente, em detrimento da valorização do conceito de gosto. Seu ponto de vista - do gosto - torna-se, conseqüentemente, secundário diante da obra de arte. As belasartes enquanto artes do gênio impõem-se como princípio transcendental na estética póskantiana.

Mediante o deslocamento dos fundamentos da estética - do conceito de gosto ao conceito de gênio - impõe-se o momento em que a perspectiva da arte assume o primeiro plano $^{110}$.

A estética torna-se possível apenas como uma filosofia da $\operatorname{arte}^{111}$. Para Gadamer, esse registro verifica-se, originalmente, com Schiller em suas Cartas sobre a educação estética para a humanidade (Über die ästhetische Erziehung des Menschen), de1795, e, em geral, com o pensamento neokantiano, para o qual a arte, conhecida como produto genial inconsciente ${ }^{112}$, incluía assim a natureza, então compreendida como um produto do espírito.

A preocupação kantiana em formular uma fundamentação autônoma para a estética sugere e promove outras formulações. Ao liberar a estética do critério do conceito - e, conseqüentemente, de sua pretensão de verdade -, o propósito de fundar o julgamento estético sobre o a priori subjetivo do sentimento da vida vai permitir ao neokantismo forjar o conceito de "vivência"113 (Erlebnis), tomando-o como fundamento gnosiológico de toda consciência objetiva. A concepção kantiana da "elevação do sentimento vital" no prazer estético permite o próprio desdobramento do conceito de gênio para um conceito de vida em seu caráter mais abrangente - o conceito de vivência. No âmbito de uma prolongada análise sobre a história do

\footnotetext{
110 “A fundamentação do juízo estético sobre um a priori da subjetividade estava fadado a ganhar uma significação totalmente nova quando se modificou o sentido da reflexão transcendental-filosófica nos sucessores de Kant. Quando deixa de existir o pano de fundo da metafísica, que fundamentou a preferência pelo belo natural, em Kant, e voltou-se a vincular o conceito de gênio à natureza, apresenta-se, em um novo sentido, o problema da arte" (id., ibid., p. 61).

111 Para Gadamer, essa relação de identidade entre estética e filosofia da arte, como conseqüência de uma "autonomia" que o ponto de vista do gênio assume no cerne das reflexões estéticas, constitui-se também como a conseqüência abstraída por todo o idealismo alemão. Em Hegel, essa formulação será expressa de modo objetivo e sistemático.

112 No século XIX, a concepção kantiana de gênio não consegue impor-se. Em seu lugar destaca-se uma compreensão de valor universal manifesto pelo conceito romântico-idealista da produção inconsciente, cuja grande repercussão dá-se com o pensamento de Schopenhauer e a filosofia do inconsciente. Trata-se de um culto à produção inconsciente e ao irracionalismo, que, por sua vez, conduz tanto a distanciar o mundo do conhecimento e da moral do mundo da arte.

113 Segundo Gadamer, é a literatura biográfica, em sua essência, que primeiro atribui cidadania à palavra "vivência" - "a partir da vida, compreende-se a obra". Esse conceito diz respeito não apenas ao que fora vivenciado, mas àquilo que, ao ser vivenciado, adquiriu uma ênfase especial e um significado duradouro.
} 
surgimento desse conceito no fim do século XIX, Gadamer, de modo enfático, desenvolve uma investigação sobre a relação de analogia entre a "estrutura da vivência (Erlebnis) e o modo de ser daquilo que revela o estético ${ }^{114}$. Nesse sentido, a vivência estética constituiria a modalidade essencial da "Erlebnis" como tal. Do mesmo modo que à "Erlebnis" corresponde, tanto para Dilthey como para Husserl, uma função epistemológica universal ${ }^{115}$, ou seja, uma unidade de sentido deduzida da continuidade da vida. Para Dilthey, ressalta Gadamer, o termo vivência constitui em seu conceito o fundamento epistemológico para o conhecimento, na medida em que "a vida é produtividade", cujas objetivações manifestam-se em imagens de sentido a serem compreendidas a partir da própria vivacidade espiritual. Nesse mesmo sentido, em Husserl, em sua Quinta Investigação Lógica - continua Gadamer -, o conceito de vivência é entendido em sua relação intencional, ou seja, "a unidade de sentido chamada vivência é também aqui uma unidade teleológica. Somente existem vivências na medida em que nelas algo se experimenta ou é intencionado" $" 116$.

Desse modo, em sua estrutura, a vivência precisa ser tomada em seu relacionamento interno com a vida; o que vale para ela não é simplesmente a fugacidade passageira presente na vida consciente, mas seu conteúdo propriamente significante, ou seja, aquilo que fica e permanece como duradouro. Por isso, "cada vivência é trazida para fora da continuidade da vida e está, ao mesmo tempo, relacionada com o todo da própria vida [...]. Na medida em que a vivência fica integrada no todo da vida, este todo torna-se também presente nela"117.

Gadamer então identifica uma relação de afinidade entre a estrutura da vivência e o modo de ser daquilo que revela o estético, já que este último representaria, exemplarmente, o conteúdo do conceito da vivência, a forma de ser da própria vivência, e não apenas um tipo de vivência. Da mesma forma que a vivência enquanto unidade de sentido é subtraída da

\footnotetext{
${ }^{114}$ Essa concepção do conceito de vivência, quando usada em sua conexão com a arte, adquire um novo status. É Dilthey, segundo Gadamer, em sua obra Das Erlebnis und die Dichtung (1905), quem pela primeira vez atribui à palavra "vivência" (Erlebnis) uma cunhagem conceitual, a partir da pré-história romântica da palavra; conceito de valor tão elucidativo, que lhe possibilitou, mais tarde, ser assimilada como estrangeirismo. Com esta obra Dilthey contribui decisivamente para a difusão do conceito de vivência, elevando-o à condição de categoria fundamentalmente estética. A arte relaciona-se a partir de então com o reino das vivências e de suas expressões. ${ }_{115}$ Dilthey desenvolveu o conceito de "Erlebnis" como instrumento fundamental da compreensão histórica e, em geral, da compreensão inter-humana. Ele a caracterizou do seguinte modo: "A 'Erlebnis' é antes de mais nada a unidade estrutural entre as formas de atitude e conteúdos. Minha atitude de observação junto com sua relação com o objeto é uma 'Erlebnis', assim como meu sentimento de alguma coisa ou meu querer alguma coisa. A 'Erlebnis é sempre consciente de si mesma" (Grundlegung der Geisteswissenschaften, II, 1). Da mesma forma, Husserl considerou a "Erlebnis" como um fato de consciência; logo, como um entre os demais conteúdos do cogito. As "Erlebnisse" de consciência são consideradas em toda a plenitude concreta com que se apresentam em sua conexão concreta - a corrente da consciência - e na qual se unificam tendo em vista a sua própria existência.

${ }^{116}$ H.-G. GADAMER, WM, I, p. 72.

${ }^{117}$ Id., ibid., p. 75.
} 
continuidade da vida, assim também a vivência estética é separada de todo contexto do real, já que a obra de arte constitui um mundo à parte, um mundo para si (für sich). Diante da obra de arte, o vivenciado esteticamente afasta-se de suas correlações com o mundo. A questão que aí se põe é que a compreensão da obra de arte consolida-se sob a perspectiva da "vivência estética"; sendo esse conceito determinante para sua fundamentação. O que, a partir de então, caracteriza a obra de arte é sua constituição como objeto da vivência estética. A arte enquanto vivência torna-se a arte verdadeira.

Sob o olhar crítico de Gadamer, a abordagem da arte enquanto vivência, no conjunto de suas argumentações, limita uma reflexão sobre o fenômeno da arte, pois tais considerações resultam em pura ilusão. $\mathrm{O}$ grande propósito da experiência da arte não se constitui em ser compreendida como vivência humana; isto não corresponde a sua destinação. "Não é a autenticidade da vivência ou a intensidade de sua expressão, mas a disposição artística de formas e maneiras fixas de dizer, que faz com que a obra de arte seja uma obra de arte" ${ }^{, 118}$.

A reflexão paradigmática do criticismo kantiano no tocante à questão do gosto, sob a revisão hermenêutica de seus conceitos básicos, resulta, como conseqüência, na afirmação do caráter duvidoso da "consciência estética" (ästhetischen Bewußtseins) ${ }^{119}$ e de todas as ponderações sobre a arte que daí advêm. Trata-se de indagar sobre o caráter de conveniência do comportamento estético assumido em face da obra de arte, questionando o problema da compreensão da arte como criação da consciência estética. Sob a forma de uma advertência, escreve Gadamer:

\footnotetext{
"Seja como for, não podemos duvidar de que as grandes épocas da história da arte foram aquelas em que a gente se acercava de configurações, sem qualquer consciência estética e sem nosso conceito de 'arte', configurações, cuja função de vida, religiosa ou profana, era compreensível para todos, e não era degustável para ninguém apenas esteticamente. Podese, acaso, aplicar a elas o conceito de consciência estética, como tal, sem restringir seu verdadeiro ser?"120.
}

Responder a essa questão significa para Gadamer, mais uma vez, inserir-se na história de um conceito; desta vez, do conceito de "consciência estética". "Estética", evidentemente, não mais corresponde àquilo que Kant entendia sob a expressão "estética transcendental", ou seja, teoria do espaço e do tempo; nem tampouco ao que este filósofo formulou como uma

${ }^{118}$ Id.,ibid., p. 77.

${ }^{119}$ A esse propósito, Gadamer também escreve, como contribuição ao Simpósio de Estética em Veneza em 1958, o texto "Zur Fragwürdigkeit des ästhetischen Bewußtseins". Publicado pela primeira vez em Il giudizio estetico. Atti del simposio di estetica, Veneza, 1958.

${ }^{120}$ Id., ibid., p. 87. 
"crítica do julgamento estético", que, por sua vez, compreendia uma doutrina do belo e do sublime na natureza e na arte. Se para Kant a arte é compreendida numa relação de complementaridade positiva com a natureza, a partir de Schiller, a arte só se constitui e se compreende a partir de uma relação de oposição com a realidade, buscando em seu ponto de vista próprio sua própria autonomia. Do antagonismo ${ }^{121}$ entre a arte, como bela aparência, e a realidade prática, aquela relação de complementação positiva entre arte e natureza é substituída pela antinomia "aparência" e "realidade". Onde predominam as leis da beleza, ultrapassam-se as fronteiras da realidade, e instala-se o reino ideal da arte.

É Schiller quem inicia o pensamento estético pós-kantiano, esforçando-se por preservar a autonomia da estética. Partindo do estabelecimento, por Kant, de um marco diferencial ao juízo de gosto, Schiller, herdeiro de uma tradição humanística, não rompe com a dimensão moral do estético, uma vez que nos fala de uma educação, essencialmente convertida em estética. Trata-se de uma educação subordinada à tendência lúdica - tendência ao jogo - inerente ao homem e que, por sua vez conduzirá as reflexões estéticas kantianas a transformações. O que fora a primazia do belo natural sobre o belo da arte agora se inverte, na medida em que o ponto de vista da estética do gosto é ultrapassado pela estética do gênio. A autonomia da estética resulta da subjetiva tendência humana ao jogo, cuja manifestação mais livre encontra-se nas criações artísticas do gênio. Assim, se a estética do gênio suplanta a estética do gosto, isto se dá porque, conforme afirma Grondin,

"com efeito, o gosto e o sentido comum exercem uma função niveladora que impede amiúde valorizar devidamente as criações geniais, porque estas vão contra o correspondente do gosto. As preferências concedidas por Kant ao belo natural e ao juízo do gosto chegam, assim, a fazerem-se caducas, porque tais preferências parecem finalmente ser incompatíveis com a plena autonomia do estético"122.

Tendo em vista esse deslocamento interno ${ }^{123}$ que se produz na base ontológica da estética de Schiller, cuja reivindicação é o predomínio próprio e autônomo para a arte, alterase, no entender de Gadamer, a realização daquilo que seria o princípio fundamental das Cartas sobre a educação estética. "Torna-se conhecido que uma educação pela arte torna-se

${ }^{121}$ Para Gadamer, Schiller altera o princípio de subjetivação radical que fundamenta a concepção do juízo de gosto em Kant. O que fora uma pressuposição metódica torna-se uma pressuposição de conteúdo. Ao afirmar a arte como exercício da liberdade, sua inspiração é, sobretudo, a doutrina dos instintos de Fichte. A meta de uma "educação estética" é precisamente o cultivo do "instinto lúdico", cuja natureza é a harmonia entre o "instinto da matéria e o da forma".

${ }^{122}$ J. GRONDIN, Introducción a Gadamer, p. 61.

123 "O ponto de virada parece encontrar-se em Schiller, que transformou o pensamento transcendental do gosto numa exigência moral, formulando-o como um imperativo: Comporta-te esteticamente!" (H.-G. GADAMER, $W M$, I, p. 87). 
uma educação para a arte. No lugar de uma verdadeira liberdade ética e política, para o que a arte deve preparar-nos, desponta a formação de um 'estado estético', uma sociedade de formação que se interessa pela arte" ${ }^{\text {124 }}$. Em seu intento de superar o dualismo kantiano da natureza - mundo dos sentidos - e liberdade - mundo ético -, Schiller instaura, a partir de suas reflexões, um antagonismo ainda mais profundo, qual seja, entre a arte e a realidade. A própria conciliação entre a vida e o ideal, prevista por meio da arte, apenas se verifica de modo muito particular, já que é só por um aparecer, um brilho transfigurado, que o belo artístico determina-se enquanto liberdade e manifesta-se na realidade. A liberdade, portanto, restringe-se a um estado estético.

O deslocamento da determinação ontológica do estético ${ }^{125}$ para o conceito de aparência estética $^{126}$, empreendido por Schiller, do ponto de vista da arte, corresponde, no entender de Gadamer, à própria compreensão da "consciência estética". O que perfaz a configuração da formação estética não é mais um padrão de gosto, de acordo com aquilo que prevalece em uma sociedade enquanto estilo de vida. Por isso, essa idéia de formação estética, segundo Gadamer, representa, claramente, a dissolução da "unidade de filiação da obra de arte com seu mundo" ${ }^{27}$. A esse respeito, diz-nos Dastur: "O que caracteriza a idéia schilleriana de cultura estética é a recusa de reconhecer o pertencimento da obra de arte a seu mundo: a obra de arte é assim, enquanto objeto da experiência estética, o produto de uma abstração [... $]^{\prime 128}$.

Tornando-se inválida a filiação da obra de arte em relação a seu mundo, o que resta é a consciência como centro de vivência que avalia a qualidade estética e a arte propriamente dita. Eis o que Gadamer qualifica de desempenho abstrato da consciência estética, já que naquilo que ela vivencia “[...] não se leva em consideração tudo em que uma obra se enraíza, como seu contexto de vida originário, isto é, toda função religiosa ou profana em que se

\footnotetext{
${ }^{124}$ Id., ibid., p. 88.

${ }^{125}$ A partir da oposição entre arte e realidade registrada na formulação estética de Schiller, Gadamer ressalta, ou melhor, ratifica que o constrangimento ontológico ao qual foi submetida a estética do século XIX é oriundo do próprio criticismo kantiano. Se o conceito de conhecimento acha-se reduzido ao predomínio do modelo de conhecimento das ciências da natureza, sob o domínio do preconceito nominalista, o ser estético torna-se desacreditado enquanto forma insuficiente e equívoca de conhecimento.

${ }^{126}$. Gadamer lembra a grande contribuição dada pela crítica fenomenológica aplicada à psicologia e à teoria do conhecimento do século XIX, na tentativa de uma melhor compreensão do ser estético. "Todos esses conceitos, como imitação, aparência, desrealização, ilusão, magia, sonho, pressupõem uma relação com o ser verdadeiro, do qual se diferencia o ser estético. No entanto, o retorno fenomenológico à experiência estética ensina que esta não pensa, de forma alguma, com base nessa relação, mas, antes, naquilo que ela experimenta, vê a genuína verdade" (id., ibid., p. 89).

${ }^{127}$ Id. ibid.,p 91.

${ }^{128}$ F. DASTUR, "La critique de la conscience esthétique chez Gadamer", in: Phénoménologie et esthétique, p. 45.
} 
encontrava e em que possuía seu significado, é aí que se tornará visível a 'pura obra de arte " ${ }^{\prime 29}$. Esse desempenho da consciência em abstrair todas as condições de acesso mediante as quais a obra apresenta-se para nós, vislumbrando "a obra de arte pura", Gadamer nomeia “diferenciação estética” (ästhetische Unterscheidung). A obra verdadeira seria aquela que se dirige à consciência estética; aquela cujos momentos extra-estéticos que a incorporam ao mundo e lhes conferem significado originário acham-se abstraídos. A soberania da consciência estética revela-se em seu propósito de diferenciar o que está intencionado (Gemeinte) esteticamente - o especificamente estético - do conteúdo extra-estético, visando a obra em si.

Ademais, a consciência estética eleva à simultaneidade tudo o que ela reconhece como arte. Ao determinar validade a tudo o que congregue valor artístico, ela, além de uma forma presente, assume também o caráter de uma consciência histórica. Nesse sentido, a diferenciação estética assume uma existência externa, cuja simultaneidade histórica é buscada em espaços como o museu ${ }^{130}$, a biblioteca, a sala de concerto e o teatro.

Ao ser realizada pela consciência estética essa diferenciação estética acarreta, tanto à arte quanto ao artista, a perda de seu lugar e seu desatrelamento do mundo. O artista cria livremente, independentemente de receber encomenda, e é justamente isso que o caracteriza: a independência de seu trabalho criativo, o comportamento excêntrico e boêmio e o distanciamento da sociedade ordinária ${ }^{131}$.

Do ponto de vista de sua configuração formativa e também conceitual, o objetivo da consciência estética é a abstração do "estético puro"132, a percepção pura da obra de arte.

\footnotetext{
$\overline{{ }^{129} \text { H.-G. GADAMER, WM, I, p. } 91 .}$

${ }^{130}$ É bastante interessante a ilustração feita por Gadamer acerca do caráter da simultaneidade da consciência estética, na medida em que a "diferenciação estética" remete-nos a um sinal distintivo do conhecimento histórico. Entretanto, os conteúdos mais antigos devem ser diferenciados dos mais recentes, o que, conforme Gadamer, pode ser observado no museu. Este "não é simplesmente um acervo que se tornou público. Mais do que isso, os antigos acervos espelhavam (nas cortes e nas cidades) a escolha de um determinado gosto e continham, preponderantemente, os trabalhos de uma mesma 'escola', concebida como exemplar. O museu, ao contrário, é o acervo de tais acervos e, caracteristicamente, alcança sua perfeição no encobrir seu próprio surgimento a partir desses acervos, quer através de uma reordenação histórica do conjunto, quer através da complementação mais abrangente possível" (Id., ibid., p. 92).

131 "O conceito de boêmia, que surgiu no século XIX, reflete esse processo. A terra natal das pessoas itinerantes torna-se um termo genérico para esse estilo de vida do artista" (id., ibid., p. 93).

${ }^{132} \mathrm{Se}$, do ponto de vista do questionamento da formação estética, Gadamer apresenta as dificuldades teóricas que se encontram no conceito do "estético" a partir da noção de consciência estética, a crítica ao caráter de sua abstração assume outros desenvolvimentos. Um deles Gadamer identifica em Richard Hamann, cujo intento também se apega à tarefa da "distinção estética" e à soberania da "consciência estética". O conceito básico de seu pensamento estético é a "significância própria da percepção". Sua leitura crítica de Gadamer remete-o às seguintes considerações: "Vista lingüisticamente a 'significância' é uma formação secundária com relação ao significado, que desloca a relação a um determinado significado significativamente para algo incerto. O que é 'significativo' tem um significado (não manifestado ou) não reconhecido. A 'significância própria' vai ainda
} 
Questiona-se então: mas em que medida a estética corresponde a um processo de percepção? Como nos lembra Gadamer, segundo Aristóteles, "toda 'aisthesis' dirige-se a um universal", ou seja, aquilo que nos impressiona os sentidos, embora seja visto de modo individual, nós o percebemos tendo como referência um universal. Desse modo, nossa percepção não se limita a um simples reflexo do que fora apreendido sensorialmente; não se restringe ao conceito de pura percepção ${ }^{133}$.

Gadamer então aplica à própria consciência estética a crítica desenvolvida à noção de percepção pura, fundamentalmente retomada por Heidegger ${ }^{134}$, quando, por sua vez, nos mostra que a percepção, ao contrário de simples reflexo dos sentidos, remete-nos muito mais a uma apreensão articulada daquilo que se apresenta.

\footnotetext{
“Toda apreensão como [...] articula o que está ali, na medida em que tira a vista de [...] olha para $[\ldots]$ vê conjuntamente como $[\ldots]$ - [...] não há dúvida de que o ver é como um ler articulado daquilo que lá está, de muita coisa que lá está, ele ao mesmo tempo desvia a vista, de maneira que para o olhar já não está mais lá; da mesma forma, porém, também guiado por suas antecipações, 'olha para dentro' e vê o que lê nem está [...]"135.
}

Desse modo, não se trata de reduzir os fenômenos a meras abstrações, mas de recuperar o conteúdo significativo da obra de arte, que não coincide com o efeito de sua "pura presença". Seu conteúdo objetivo está sempre vinculado à obra, à unidade de sua forma e de seu significado, de seu modo de ser. Compreendê-lo só é possível por meio de uma verdadeira leitura capaz de articular seus diferentes elementos em uma unidade de sentido. À luz dessa crítica incorporada por Gadamer, não há mais sentido em falar-se de uma pura receptividade estética. Como diz Gaos, leitor de Heidegger, “o 'ver em torno' dirige-se a um abarcar com a vista a totalidade" ${ }^{, 136}$; um ver que corresponde e abarca os limites do mundo circundante. A percepção não corresponde a meras abstrações dogmáticas referentes ao ver e ao ouvir, mas, bem pelo contrário, ela abrange sempre o significado. "Só quando reconhecemos o que está representado, podemos 'ler' uma pintura, só então é que ela é, no fundo, uma pintura. Ver significa subdividir desmembrando [...]"137.

além disso [...] Será que um tal conceito pode constituir um fundamento resistente para a estética?" (id., ibid., p. 95).

${ }^{133}$ Gadamer mostra que esse conceito de pura percepção do estímulo recíproco constitui-se como expressão de um dogmatismo epistemológico e que, nesse sentido de adequação do estímulo, sua crítica foi desenvolvida pela psicologia de Max Scheler.

${ }^{134}$ M. HEIDEGGER, El ser y el tiempo, $\S 32$ e $\S 33$.

${ }^{135}$ H.-G. GADAMER, $W M$, I, p. 86.

${ }^{136} \mathrm{~J}$. GAOS, Introducción a El ser y tiempo, p. 88.

${ }^{137}$ H.-G. GADAMER, WM, I, p. 97. 
Isso também vale, ressalta Gadamer, para a arte dita abstrata, que de modo negativo estabelece uma ligação com o figurativo. Por menor que seja, este tipo de arte sempre comporta uma relação a uma referência objetiva. Uma visão estética pode resultar da capacidade de abstrairmos do objeto as considerações pertinentes a sua utilidade prática. Entretanto, disso que o apartamos é o fundamental para vermos nele e mantê-lo na visão. Enquanto abstrações dogmáticas, tanto a visão pura, quanto audição pura constituem-se como expressão de um "formalismo", na medida em que, na obra de arte, sua unidade de configuração estética não pode ser buscada apenas em sua forma. Seu conteúdo objetivo não se baseia no fato de a matéria permanecer à espera de uma conformação exterior, mas, bem pelo contrário, está fundamentalmente vinculado à unidade da forma e do significado.

Eis a condição de possibilidade para que a estética, ultrapassando-se a si mesma, renuncie à "pureza" transcendental do estético e reconheça na arte seu autêntico modo de ser.

Assim, se não é do ponto de vista da função transcendental do conceito de gênio no pensamento kantiano - tampouco de sua ampliação a uma base universal da estética, desenvolvida por seus sucessores -, nem do caráter de fundamentação da vivência estética ${ }^{138}$, de que forma buscar uma base segura que fundamente a compreensão do modo de ser da arte?

À concepção estética de pura percepção - a pura visão estética -, Gadamer, em oposição, apresenta a idéia de uma "experiência estética" que, distanciada do caráter imediato da vivência (Erlebnis), busque compreender-se a si mesma. O encontro com a obra é o encontro com a particularidade de um mundo, portanto, não pode ser restrito a um encantamento momentâneo. Bem mais que isso, constitui uma experiência que nos permite a aprendizagem da autocompreensão, desde que abandonemos o caráter descontínuo e pontual da vivência em prol da unidade de compreensão da própria existência. Tomar a arte como experiência significa aqui resgatá-la dos parâmetros conceituais da "consciência estética",

\footnotetext{
${ }^{138}$ No objetivo de buscar uma forma que faça jus ao conhecimento da obra de arte, em sua unidade, Gadamer refere-se ao problema identificado por Lukács no tocante ao conceito de "vivência estética". "Ele confere à esfera estética uma estrutura heraclítica, e com isso quer dizer o seguinte: a unidade do objeto estético não chega a ser uma situação dada real. A obra de arte é apenas uma forma do vazio, o mero ponto nodal da possível maioria das vivências estéticas, nas quais se encontra apenas o objeto estético. Como se vê, há absoluta descontinuidade, isto é, decomposição da unidade do objeto estético na multiplicidade de vivências [...]. A fundamentação da estética na vivência conduz à absoluta pontualidade, que suspende tanto a unidade da obra de arte como a identidade do artista consigo mesmo e a identidade de quem a compreende ou a usufrui" (Id., ibid., p. 101). Convém também citar a indicação gadameriana da contribuição significativa de Kierkegaard, pioneiro a descrever a autodestruição da imediatidade estética sob a forma de uma crítica à consciência estética. "Na medida em que o estágio estético da existência mostra-se em si insustentável, reconhece-se que o fenômeno da arte põe uma tarefa à existência: a de, em face da atualidade exigente e arrecadadora da respectiva impressão estética, alcançar a continuidade da auto-evidência, que somente a existência humana [Dasein] pode sustentar" (id., ibid.,).
} 
pois sua reflexão não pode estar comprimida ao significado de "vivência" - invocação à imediatidade. Sua reflexão deve remeter-nos sempre à dimensão daquilo que é evidente na existência humana, àquilo que corresponde a sua dimensão histórica.

Em outras palavras, ultrapassar a radical subjetivação do estético, assinalada originariamente pelo criticismo kantiano, torna-se possível, tendo em vista a reconsideração da obra de arte como experiência, bem como mediante a sua atribuição cognitiva: a arte é conhecimento, e sua experiência torna-o partilhável, comunicável.

Se não é, porém, dando prosseguimento a uma abstração estética metódica - com vistas a sua fundamentação transcendental -, ou mesmo de conteúdo - a arte do ponto de vista meramente estético -, como articular uma reflexão hermenêutica sobre o domínio do belo artístico? A resposta parece advir do próprio questionamento gadameriano: "Será que não deve haver nenhum conhecimento na arte? Não há, na experiência da arte, uma reivindicação à verdade, que, sendo certamente diversa da ciência, certamente também não lhe será inferior? E será que não reside a tarefa da estética justamente em fundamentar que a experiência da arte é uma forma de conhecimento dos sentidos [...], mas que é, contudo, conhecimento, ou seja, transmissão de verdade?"139.

Aqui parece estar o núcleo temático fundamental que caracteriza a singularidade da relação estética e hermenêutica no pensamento de Gadamer. A questão da verdade da arte assume dessa forma legitimidade no processo de elaboração dos fundamentos de uma hermenêutica. Tudo depende de como o conceito de experiência e de conhecimento verdadeiro são mensurados. Renovar a indagação com respeito à verdade da arte significa uma tentativa de correção da auto-interpretação da consciência estética, no modo pelo qual pensa sua própria experiência. Se a arte tem uma pretensão de verdade, sua compreensão advém de seu modo de ser entendida como experiência e do caráter sui generis de sua manifestação; experiência a partir da qual a própria verdade vem a nosso encontro sob a forma da linguagem da arte.

Se retornarmos à questão inicial e nos perguntarmos qual a importância específica do fenômeno artístico para uma discussão epistemológica acerca das ciências humanas, parece não ser suficiente apenas a hipótese de que a experiência da arte é um lugar privilegiado em que a verdade se expõe. O que possibilita ao fenômeno da arte constituir-se como uma experiência paradigmática para a elaboração dos fundamentos de uma hermenêutica filosófica

\footnotetext{
${ }^{139}$ Id.ibid., p. 103.
} 
e que, portanto, justifica toda a primeira parte de Verdade e método? O que torna a experiência da obra de arte bem mais convincente que um argumento científico ou filosófico para discutir a questão da verdade? Eis o problema central que orienta nosso trabalho. Nesse primeiro momento convém termos clareza sobre os seguintes argumentos.

Remetendo-nos ao sentido primordial da hermenêutica como arte da interpretação, a principal dificuldade de sua tarefa estaria na tentativa de salvaguardar as intenções de sentido inerentes ao todo das próprias experiências hermenêuticas; dificuldade essa que leva Gadamer a caracterizar a filosofia justamente como aquele "saber do quanto fica de não dito quando se diz algo"140. Enquanto interpretação, o que pretende a hermenêutica filosófica é discordar de toda e qualquer delimitação lógico-científica do saber humano - em cuja meta a filosofia iluminista insistiu -, na medida em que tal procedimento descarta seu enraizamento próprio no processo de interpretação, neutralizando qualquer instauração de sentido. Pelo contrário, na qualidade de interpretação, essa proposta hermenêutica intenta advertir a racionalidade científica moderna quanto à importância e necessidade de seus fundamentos na experiência pré-lógica. Intenta lembrá-la da tradição do saber humano, cuja busca da verdade é muito mais confiada à experiência da interpretação e ao reconhecimento do estranho do que à postura de subsumir a realidade vivida às delimitações impostas pela lógica conceitual legitimada pelas ciências objetivadoras. Assim, se o questionamento sobre o domínio estético e principalmente acerca do fenômeno da arte é assimilado como argumentação de análise inicial, imprescindivel para a compreensão da hermenêutica filosófica, é porque o propósito dessa última, como diz o filósofo, "não se tratava [...] de uma teoria da ciência ou de uma teoria das ciências do espírito. Pelo contrário, eu queria mostrar que, nas ciências do espírito, não apenas as ciências e métodos possuem um papel, mas sim sobretudo a presença misteriosa

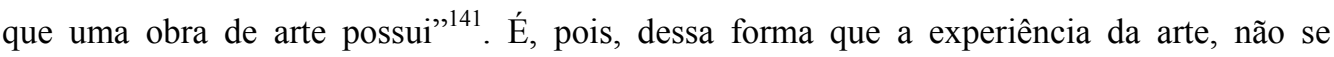
inserindo nos parâmetros metodológicos do rigor e do conceito, afasta-se do modelo gnosiológico de experiência verdadeira segundo a idéia fundamental de modernidade científica. Entretanto, enquanto presença misteriosa, ela anuncia uma forma de verdade a ser desvelada. Recuperar sua função de verdade é inserir-se no horizonte de sua reflexão ontológica como condição de possibilidade para decifrar a experiência hermenêutica e o próprio fenômeno da compreensão.

\footnotetext{
${ }^{140}$ H.-G. GADAMER, "Retrospectiva dialógica à obra reunida e sua história de efetuação", in: C.S. ALMEIDA; H.-G. FLICKEINGER; L. ROHDEN, Hermenêutica filosófica: Nas trilhas de Hans-Georg Gadamer, p. 211.

${ }^{141} I d$., ibid., p. 205.
} 
É tarefa da hermenêutica filosófica de Gadamer recuperar a possibilidade de conquista da legitimidade das ciências humanas. Portanto, além de analisar a procedência dessa problemática epistemológica, seu intento é superá-la. Assim, a crítica ao metodologismo moderno e ao processo de subjetivação estética decorrentes desse estreitamento proporcionado à tradição humanista necessita de uma demonstração prática, baseada em uma experiência humana universal. Do empenho de uma reflexão crítica contundente e necessária direcionada à "consciência estética" e ao princípio transcendental de subjetivação impostos pelo criticismo kantiano, resulta uma análise sobre a questão da verdade da arte, tendo em vista a ressignificação ontológica tanto do conceito de arte quanto do conceito de verdade (aletheia).

Assim se justifica o lugar e a condição de importância que o fenômeno da arte apresenta para a definição da proposta hermenêutica de Gadamer. Se a busca de autoevidência das ciências humanas foi interrompida pela subjetivação e estetização dos pilares fundantes do humanismo, o que gerou equívocos e perdas, o momento agora é de retomar a reflexão estética, pondo-a a serviço da hermenêutica, ou seja, como medida para o propósito de desvelamento e autonomia das ciências humanas. Recuperar o fenômeno da arte como esfera de conhecimento significa, para a hermenêutica de Gadamer, o procedimento reflexivo imediatamente necessário para também recuperar o caráter de verdade de toda experiência humana universal, bem como a auto-evidência das ciências do espírito. A significação conferida à estética pela Aufklärung alemã acarretou uma problemática de sentido, cujo desvelamento constitui, fundamentalmente, a possibilidade de demonstração da insuficiência da auto-interpretação das ciências humanas (Geisteswissenschaften).

Assim, investigar a relação estética e hermenêutica na filosofia de Gadamer implica não podermos prescindir dos fundamentos e pretensão de seu projeto de uma ontologia hermenêutica. A peculiaridade dessa relação define-se, portanto, a partir da necessidade de uma ressignificação do conceito de verdade no âmbito das ciências humanas, sobretudo em um horizonte no qual o ser humano imediatamente imprime a marca de sua natureza espiritual. O privilégio que a arte então apresenta no âmbito dessas discussões aponta para o próprio desafio de recuperá-la como experiência essencialmente hermenêutica da verdade. 


\section{A EXPLICITAÇÃO ONTOLÓGICO-HERMENÊUTICA DA ARTE}

Acompanhando-se o desenvolvimento da análise feita por Gadamer, na primeira parte de Verdade e método, observamos que o procedimento de uma "crítica à consciência estética", ao mesmo tempo em que questiona o processo de auto-evidência das ciências humanas, insere-nos na indagação sobre a verdade da arte. Esse fato torna-se curioso na medida em que buscamos entender o que o justifica, bem como de que forma se desenvolve, essa pergunta. A respeito disto, diz-nos Gadamer:

"Não iremos ter de aceitar a resposta da auto-evidência das ciências do espírito, mas
teremos de indagar o que é, na verdade, sua compreensão. Na preparação dessa pergunta
de longo alcance, o que poderá servir, em especial, será a indagação sobre a verdade da
arte, justamente porque inclui a compreensão da experiência da obra de arte, ou seja,
representa até mesmo um fenômeno hermenêutico, e não, certamente, no sentido de um
método científico. A compreensão pertence, antes, ao próprio encontro com a obra de arte,
de maneira que apenas do ponto de vista do modo de ser da obra de arte é que se pode
aclarar essa pertença"142

Embora não como uma estética propriamente dita ${ }^{143}$, verifica-se aqui um deslocamento reflexivo que submete a obra de arte à tarefa crítica da hermenêutica filosófica. Uma vez que o testemunho da arte revela uma concepção de compreender que não é instrumental, é com base nessa significação que Gadamer identifica um modo mais adequado desse fenômeno - a compreensão -, a ser desenvolvido nas ciências humanas. Dessa forma, o fenômeno da arte representaria uma tarefa de integração, de modo que o propósito de sua reflexão constitui-se bem mais em tomá-la como experiência hermenêutica do que como experiência estética propriamente dita. Embora a reflexão sobre a experiência da arte seja considerada a partir do cenário de nascimento e desenvolvimento da estética, bem como num contexto específico de sua análise em que a esfera da arte ora, radicalmente, se distancia, ora se aproxima e se identifica enquanto experiência cognitiva, a indagação acerca de sua abordagem filosófica, aqui, desenvolve-se, fundamentalmente, no âmbito de uma problemática hermenêutica.

Do ponto de vista da significação desse recurso gadameriano de reivindicar para a arte sua verdade, a nova dimensão do "compreender", fornecida pela filosofia de Heidegger, é, conforme mencionamos anteriormente, fundamental. Por conseguinte, perguntar pela verdade da arte é desde já tomá-la como fenômeno hermenêutico, cuja compreensão só se torna

\footnotetext{
${ }^{142}$ H.-G. GADAMER, WM, I, p. 106.

143 "Se nos permitem a expressão, poder-se-ia dizer que, de parte do objeto, o caminho para a estética expressa, para Verdade e método, expressa uma espécie de desvio. Apesar de todas as concepções positivas sobre a arte, a parte introdutória de Verdade e método oferece mais uma antiestética do que uma estética" (J. GRONDIN, Introdução à hermenêutica filosófica, p. 185).
} 
possível por meio da análise ontológica da experiência artística. O vir-nos ao encontro da obra de arte é uma provocação para nossa própria compreensão, provocação porque articula em sua linguagem o que fica reprimido em sua reflexão racional e subjetiva e o exibe na abrangência expressiva de seu aparecer. Eis aí o que testemunha a favor da primazia da experiência ontológica. É na reflexão sobre seu modo de ser que a ontologia da obra de arte constitui-se como chave decifratória da experiência hermenêutica, anunciando, por sua vez, os elementos fundadores do compreender - a disposição à abertura, o remeter-se à alteridade e o âmbito da linguagem, esse horizonte radical que estabelece nosso encontro com o mundo.

Se, como anteriormente destacamos, o que torna hermenêutico o universo estético é o próprio caráter declarativo da obra de arte a partir do qual esta vem a nosso encontro, a análise sobre sua verdade não pode prescindir do conceito mesmo de experiência. É nessa particularidade de vir a nosso encontro que a arte ganha seu diferencial enquanto experiência de verdade. Por isso, é também enquanto experiência hermenêutica que se torna possível renovar a indagação com respeito à verdade da arte; elucidando, assim, a experiência da arte como experiência, "uma genuína experiência em obra, que não deixa inalterado aquele que a faz" ${ }^{\prime 144}$. Apenas dessa forma é que podemos, segundo Gadamer, melhor entender o que é essa verdade que nos vem ao encontro.

\subsection{Sobre o conceito de experiência}

Retomar a problemática fundamental da experiência humana parece ter como objetivo, sobretudo, a justificativa do estatuto histórico da hermenêutica filosófica de Gadamer. Embora o momento de sua exposição em Verdade e método desenvolva-se como elemento de análise essencial da consciência histórica, apenas na segunda parte da referida obra, a discussão de sua problemática perpassa toda a estrutura de desenvolvimento dos fundamentos de uma hermenêutica filosófica ${ }^{145}$. Na realização de seu objetivo encontra-se a crítica ao estatuto teórico-metodológico da hermenêutica filosófica moderna em sua reflexão sobre o

\footnotetext{
${ }^{144}$ H.-G. GADAMER, WM, I, p. 106.

145 “A concepção moderna puramente metódica da experiência é discutida em toda a obra Verdade e método, apesar de ser apenas na segunda parte que o autor ocupa-se especificamente do conceito de experiência. A problemática central das três principais partes pelas quais se divide esta obra é, sem dúvida, a da experiência, que nelas é tratada de um modo estruturalmente semelhante: a revelação do caráter insuficiente da perspectiva metódica da experiência da arte, da historia e da linguagem acaba por dar lugar a um outro sentido mais profundo - o sentido hermenêutico - da experiência" (M.L. PORTOCARRERO, O preconceito em H.-G. Gadamer, p. 27).
} 
saber científico, a consciência e a verdade ${ }^{146}$. Como lembra Gadamer, o "fenômeno hermenêutico não é originariamente um problema metodológico"147, pois os propósitos de compreender e interpretar, bem longe de constituírem específicos desígnios da ciência, pertencem à vastidão das experiências humanas.

Desde o início de sua análise, Gadamer orienta-se pela crítica a um conceito de "experiência" totalmente voltado e adequado a seu aparato científico-natural e metodológico e, conseqüentemente, indiferente ao caráter histórico, característico de toda e qualquer experiência. Numa primeira designação, a experiência estaria a serviço da ciência experiência científica -, que, no propósito de objetivá-la, abstrai seu objeto de seu próprio espaço histórico, adequando-o metodicamente. Elas, as experiências, precisam ser comprovadas de acordo com a validade de suas respectivas confirmações. Para Gadamer, isso também vale para as ciências humanas, quando da aplicabilidade do método histórico-crítico que lhe é correspondente. Em todos os seus domínios, o intento da ciência mantém-se como o de tornar todos os seus experimentos objetivos e verificáveis. Desse modo, se no âmbito da ciência moderna a experiência, tomada em sua essência, é excluída dos elementos de sua historicidade, sua significação seria incompatível e também excluiria os dados específicos das ciências humanas.

O crescente domínio da natureza é oriundo, sustenta Gadamer, do próprio conceito de ciência moderna, cunhado pelo desenvolvimento da ciência da natureza no século XVII. Como seu exímio representante no campo da filosofia temos o criticismo kantiano, sobretudo com a obra Crítica da razão pura (Kritik der reinen Vernunft). A partir desta, a moderna ciência da natureza, no horizonte de seus fundamentos e na imposição de seus limites, assume uma relação de autoridade em face da metafísica dogmática. Para Kant, tanto o modelo da verdade quanto o do conhecimento eram representados pela ciência físico-matemática. A experiência, no âmbito de seu contexto, era então considerada uma das condições de

\footnotetext{
${ }^{146} \mathrm{Na}$ tentativa de superar as limitações do historicismo, Gadamer recorre muitas vezes a Hegel, chegando, até mesmo, a reconhecer que apenas a partir dele a consciência emerge de uma efetivação histórica. E ao entender-se a si mesma a partir da história constitui-se como autoconsciência. Gadamer, entretanto, desenvolve um enfrentamento a essa compreensão idealista e a pretensão totalizadora e reflexiva do sistema hegeliano. Ao caráter fechado da filosofia da reflexão, a pressupor uma consciência de si mesmo, como há uma consciência de um objeto, Gadamer contrapõe o caráter de abertura da experiência hermenêutica. A consciência, por mais que seja consciência de um mundo que nela se reflete, cai num risco de apenas poder olhar a si se for tomada unicamente na metáfora do refletir-se, encarada de um modo restrito. Pela auto-reflexão, a consciência eleva-se a si mesma ante a consciência, o que implica, à subjetividade, uma noção de espelho deformante. Diante da impenetrável autotransparência da reflexão, o hermeneuta propõe a concepção de uma consciência hermenêutica que articula a permanência de uma abertura ao outro, assimilando o próprio caráter de sua finitude.

${ }^{147}$ H.-G. GADAMER, WM, I, p. 1.
} 
possibilidade do conhecimento, seu verdadeiro princípio. Por meio delas as coisas eram diretamente fornecidas ou mesmo dadas na sensibilidade. Diz-nos o filósofo:

"Todo o nosso conhecimento começa com a experiência. Este fato não levanta qualquer
dúvida. De fato, o que é que poderia acordar e pôr em exercício o nosso poder de conhecer
se não fossem os objetos que tocam os nossos sentidos que, por um lado, produzem por si
mesmos representações e, por outro, põem em movimento a nossa faculdade intelectual de
modo que ela compare, ligue ou separe estas representações e trabalhe assim a matéria
bruta das impressões sensíveis para dela retirar um conhecimento dos objetos, aquele a
que chamamos experiência. De um ponto de vista cronológico, nenhum conhecimento
precede em nós a experiência e é com ela que todos começam""

Se na sensibilidade os objetos são dados tendo em vista a própria determinação empírica da experiência humana, é apenas sob a aplicação da razão pura que esta surge como experiência objetiva mediante a combinação dos dados confusos da sensibilidade. A experiência subordina-se ou mesmo é condicionada pela razão (Vernunft). Só enquanto experiência objetivada pelas categorias do entendimento é que a experiência torna-se possível como via de verdade. Sobressai a partir do legado kantiano a idéia central que norteia a possibilidade da ciência, cujo ponto de sustentação implica que só conhecemos as coisas tendo em vista seu caráter fenomênico, ou seja, na medida em que, estando configuradas pela estrutura transcendental e subjetiva da razão, as coisas nos aparecem. Nunca conhecemos o "em si" das coisas.

Inserindo-se num movimento surgido na filosofia do século XX que, de acordo com Heidegger, resgata a possibilidade de pensar a experiência ontológica ou a experiência do ser, tendo em vista seu próprio esquecimento, já ocorrido, Gadamer assume como ponto de partida o questionamento da unilateralidade dos pressupostos teórico-epistemológicos da concepção moderna de experiência. O âmbito limitado da noção de experiência objetivada decorre, por conseguinte, da própria concepção de ciência moderna, bem como da justificação filosófica dos conceitos de conhecimento e verdade. Atender à necessidade de alargar a compreensão tradicional desse conceito de experiência, no intuito de pensar outros tipos de experiência nos quais se anuncia uma verdade que não pode ser testada e verificada pelo aparato metodológico da ciência, constitui o objetivo visado pela hermenêutica filosófica de Gadamer.

Como diz Portocarrero: "O problema nuclear da nova hermenêutica é, pois, o da experiência humana histórica, ou seja, o da legitimação de uma forma de verdade, cujo encontro exceda o domínio limitado da consideração puramente epistemológica da presença das coisas" ${ }^{\text {149 }}$. Discutir a concepção metódico-conceitual da experiência, segundo Gadamer,

\footnotetext{
${ }^{148}$ I. KANT, Kritik der reinen Vernunft, Einleitung, p. 45.

${ }^{149}$ M.L. PORTOCARRERO, O preconceito em H.-G. Gadamer, p. 28.
} 
significa ultrapassar o primado transcendental da consciência em que Kant encerrara a possibilidade humana da verdade, permitindo à consciência moderna o reconhecimento de seus próprios limites. Kant, atento àquilo que, segundo Heidegger, caracteriza a tradição do pensamento ocidental, isto é, o "esquecimento do ser", ignora a possibilidade de uma experiência das condições transcendentais de toda experiência - a experiência transcendental do ser. Sua crítica da razão teórica, núcleo fundamental de onde emerge a força do pensamento reflexivo moderno da experiência, restringe, de forma empobrecedora, o horizonte da própria experiência. A possibilidade de sua interpretação limita-se à sua referência teleológica ao saber matemático e à busca da verdade que, a partir dela, pode-se alcançar.

Ainda nesse sentido, Gadamer reporta-se ao início da moderna teoria da ciência e da lógica, identificando em Francis Bacon uma especial contribuição no tocante à questão do emprego puro de nossa própria razão. Para além de uma teoria de indução verdadeira, a reflexão sobre a experiência aponta também para uma discussão antropológica quando se trata de pensarmos seu desempenho. Diz Gadamer:

\footnotetext{
“Convém recordar que em Bacon o termo experimento não se refere somente à organização técnica do investigador naturalista, que acrescenta artificialmente e torna mensuráveis determinados processos sob condições de isolamento. Experimento é também e sobretudo um hábil direcionamento de nosso espírito, que é impedido de abandonar-se a generalizações prematuras, que aprende a variar conscientemente as observações que ele impõe à natureza, aprende a confrontar conscientemente os casos mais distantes, na aparência, menos relacionados, e desse modo vai ascendendo gradual e continuamente até os axiomas, pelo caminho de um procedimento de exclusão" ${ }^{\text {150 }}$.
}

A grande contribuição de Bacon, ressalta Gadamer, estaria na exigência de uma purificação da razão humana tendo em vista a abrangência dos preconceitos (Vorurteile) que, além de ocuparem o espírito humano, desviam-no da verdade. Purificação que se determinaria sob a disciplina de uma limpeza metódica, que, por sua vez, possibilitaria um uso metódico da própria razão. "É o que ocorre, por exemplo, quando entre os idola tribus Bacon menciona a tendência do espírito humano a reter na memória unicamente o positivo e esquecer as instantiae negativae" ${ }^{151}$. Nessa "intenção excludente" de momentos na vida da experiência, recusa-se todo caráter lingüístico-relacional ou mesmo histórico-preconceptual de toda compreensão, o que torna a experiência humana radicalmente limitada e empobrecida.

\footnotetext{
${ }^{150}$ H.-G. GADAMER, $W M$, I, p. 354.

${ }^{151} I d$., ibid., p. 355.
} 
Ora, uma compreensão que tenha clareza da constelação de sentidos que envolve a experiência do conhecimento sempre manterá um esforço para averiguar seus próprios preconceitos. Com base nessa formulação, Gadamer nem sequer renuncia ao ideal, proposto pela Aufklärung, qual seja, o de elucidar os preconceitos. Segundo ele, o preconceito da Aufklärung estaria, precisamente, no preconceito que esta sustentaria contra os preconceitos. Com efeito, esse descrédito direcionado a todos os preconceitos justifica-se tendo em vista a concepção de que o verdadeiro está restrito a fundamentações de certeza lógico-matemática. Com base nesse raciocínio, Gadamer sustenta a necessidade de uma ressignificação sobre o caráter negativo adquirido por este termo, no sentido de adequá-lo, de modo mais justo, à realidade objetiva, bem como ao caráter de historicidade inerente a nosso entender. Eis o que justifica retomarmos, posteriormente, a questão da reabilitação dos preconceitos como condição de possibilidade para a fundamentação hermenêutica do problema da compreensão no seu caráter essencialmente histórico.

Desse modo, analisar o conceito de experiência é ultrapassar a orientação que limita sua problemática ao horizonte teleológico do conhecimento e à perspectiva de seus resultados. Pensar sua essência não significa considerá-la apenas por referência à ciência, o que em muito a simplificaria. Não se trata da experiência que o cientista prepara em seu laboratório, sujeita a repetições e verificações e para a qual ele converte-se em seu senhor, na medida em que submete à prova e a contrastes suas hipóteses, deduzindo daí seus resultados. Bem pelo contrário, a reconsideração do conceito de experiência desenvolvido pela hermenêutica apresenta-se como revolucionária, pois questiona a própria segurança e controle da consciência. Privando-a de suas certezas, a consciência agora é confrontada com a própria finitude de suas experiências. O que aqui está em questão é a experiência que a consciência vive. Por conseguinte, em oposição ao mito de um conhecimento de caráter eminentemente conceptual e verificável, Gadamer apresenta o conceito de experiência em sua significação histórica e dialética. Sob essa perspectiva, o conhecer não se constitui como um fluxo de percepções, mas como um processo cuja formação contempla rupturas e refutações, negatividade. Essa forma de experiência Gadamer denomina dialética. Sua referência é a reflexão hegeliana sobre a negatividade da experiência na consciência, fundamento primordial para sua hermenêutica dialética.

Diz-nos Gadamer:

"Para o momento dialético da experiência, nosso testemunho mais importante já não é Aristóteles, mas Hegel. É nele que o momento da historicidade obtém seu pleno direito. 
Hegel concebe a experiência como realização do ceticismo. Já vimos que a experiência que fazemos transforma todo o nosso saber. Em sentido estrito não é possível 'fazer' duas vezes a mesma experiência. É verdade que faz parte da experiência o fato de que ela se confirme continuamente. E também somente se a adquire pela repetição. Mas enquanto uma experiência repetida e confirmada já não se 'faz' de novo. Quando se fez uma experiência, isto quer dizer que a possuímos. Desde esse momento, o que era antes inesperado é agora previsto. Uma mesma coisa não pode voltar a converter-se para nós numa experiência nova. Somente um fato novo inesperado pode proporcionar a quem possui experiência uma nova experiência. Desse modo, a consciência que experimenta inverteu-se, ou seja, voltou-se sobre si mesma. Aquele que experimenta torna-se consciente de sua experiência, tornou-se um experimentador: ganhou um novo horizonte dentro do qual pode converter-se para ele em experiência" ${ }^{\prime 152}$.

A experiência tal como Hegel a define é experiência da consciência, logo, corresponde a um produto do encontro do sujeito com o objeto. Tomada aqui como um processo, ela é uma espécie de movimento dialético, já que tem a estrutura de uma inversão, voltando-se sobre si. Experiência da consciência significa aqui o percurso ou movimento ${ }^{153}$, através do qual, a consciência, em sua capacidade de representar, busca conhecer o "em si"; vislumbrando dessa forma a certeza de si mesma. Ressalte-se, até mesmo, que a Fenomenologia do espírito (Phänomenologie der Geist, 1807), escrita por Hegel aos 37 anos, teve como primeiro título escolhido pelo autor "Ciência da experiência da consciência" $" 154$. Nesta obra o filósofo ressalta e descreve a experiência que a própria consciência faz de si mesma ao experimentar as coisas, isto é, a experiência em seu experimentar-se a si mesma através de sucessivas formas de saber.

A questão, ressalta Gadamer, que Hegel busca então desenvolver é: como a consciência converte-se em consciente de si mesma, ou seja, torna-se autoconsciente ${ }^{155}$ Para Hegel, está bastante claro que o saber consuma-se como resultado da plena consciência entre certeza e verdade. Por conseguinte, a consciência não pode ser entendida como um mero reflexo do mundo objetivo, devendo esta progredir à condição de autoconsciência; além de seu modo de ser individual e subjetivo, inclui também seu ser espiritual. Sendo sua tarefa a análise da autoconsciência, esta não se constitui como algo previamente dado, mas como algo a ser

\footnotetext{
${ }^{152}$ H.-G. GADAMER, $W M$, I, p. 359.

${ }^{153}$ Em sua análise do conceito de experiência diz Hegel, citado por Gadamer: "O movimento dialético que a consciência realiza consigo mesma, tanto em seu saber, como em seu objeto, na medida em que para ela o novo objeto verdadeiro surge daí, é, na realidade, o que chamamos 'experiência"” (G.W.F. HEGEL, Phänomenologie des Geistes, Einleitung, p. 73; citado em H.-G. GADAMER, WM, I, p. 360).

${ }^{154}$ Sobre esse título, "Ciência da experiência da consciência", e o seu substituto correlato, "Fenomenologia do Espírito", ver M. HEIDEGGER, O conceito de experiência em Hegel.

${ }^{155}$ Cf. H.-G. GADAMER, La dialéctica de Hegel, p. 49.
} 
propriamente demonstrado mediante o caminho de apresentação (Darstellung) do saber, caminho da consciência natural que procura o saber verdadeiro.

Diz Hegel na Introdução da Fenomenologia do espírito:

"Uma vez que esta apresentação apenas tem por objeto o saber que aparece, assim não parece que ela mesma seja a ciência livre, movendo-se na sua peculiar figura, mas pode, sim, ser tomada, deste ponto de vista, como o caminho da consciência natural que procura o saber verdadeiro, ou como o caminho da alma que percorre a série de suas configurações, como, se pela sua natureza, lhe fossem estações predeterminadas, apurando-se no espírito, na medida em que alcança, pela experiência integral de si mesma, o conhecimento daquilo que em si ela é"156.

Esse caminho de apresentação, por meio do qual o saber aparece (Vorschein), ressalta Heidegger ${ }^{157}$, não é meramente um caminho de distanciamento progressivo da ciência natural rumo ao saber absoluto, mas um itinerarium no sentido mesmo de apresentação (Darstellung), um percurso, cuja especificidade do movimento que conduz, de "um lado para outro", traz à luz, aparece. Enquanto caminho, seu sentido é negativo, já que, do ponto de vista da consciência natural, reiteradamente, questiona o que é tomado como verdadeiro mediante o duvidar. Ao apresentar-se, o saber exerce o caminho da dúvida, do desespero (Verzweiflung). Dúvida (Zweifel) aqui correspondendo àquele estado de inquietação e desespero característico de quem está em dúvida (Verzweiflung), daquele que vive a dúvida.

Sobre o sentido de "consumação do desespero" em sua correspondência com aquilo que Hegel denomina “ceticismo consumando-se a si mesmo", escreve Heidegger:

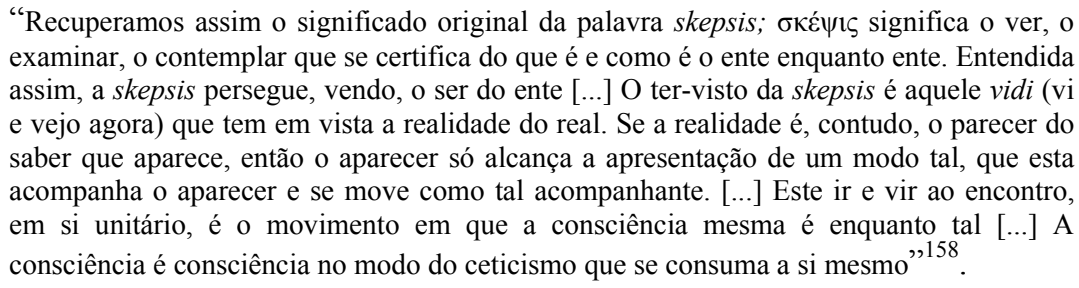

Nesse movimento do aparecer da consciência, ou seja, do processo de sua formação, a noção de ceticismo, que põe tudo à prova sem prender-se a evidências limitadas, ultrapassa qualquer propósito de autoridade subjetiva particular ou mesmo valor de uma atitude. Desse modo, a consciência exerce sobre ela mesma e sobre seu objeto um movimento dialético que

\footnotetext{
${ }^{156}$ G.W.F. HEGEL, Phänomenologie des Geistes, p. 72.

${ }^{157}$ Cf. M. HEIDEGGER, O conceito de experiência em Hegel.

${ }^{158}$ Id., ibid., p. 180.
} 
Hegel também denomina experiência ${ }^{159}$. E é com base na tendência que a experiência tem para a inversão da consciência - uma consciência que quer saber de seu próprio percurso e, portanto, de sua autoconsciência - que a negatividade surge como primeira dimensão formadora desta. Ela é experiência da consciência porque o ceticismo que nela se consuma, ao mesmo tempo em que é uma marcha da dúvida, constitui também "o diálogo [Gesprach] entre o saber natural e o saber absoluto"

Antes de tudo, a verdadeira experiência é experiência da negação - as coisas não são como as tínhamos pensado anteriormente. Em sua realização, alteram-se os dois elementos, o objeto e nosso saber sobre ele. O objeto é da ordem daquilo que não se sustenta, por isso ao longo da experiência é sempre visto sob uma luz diferente, proporcionando-nos saber melhor acerca dele - "o novo objeto contém a verdade sobre o anterior"161. Compreender a experiência como o ato de a consciência tomar-se a si mesma como objeto também significa que, nessa inversão, a experiência reconhece a si mesma na alteridade; um caminhar necessário pela negatividade que conduz a um saber-se a si mesmo. Portanto, é uma experiência que nos surpreende, frustra nossas expectativas, bem como nos conduz a mudar nosso modo de pensar. A experiência que nos limita a confirmar apenas aquilo que já sabemos não se constitui, nesse sentido, uma experiência verdadeira, já que nela nada mais se experimenta. É o caráter próprio de sua negatividade que nos proporciona compreensão, abrindo-se a novos horizontes. Por isso, diz Gadamer: "A negatividade da experiência possui, conseqüentemente, um particular sentido produtivo. Não é simplesmente um engano que se torna visível e, por conseqüência, uma correção, mas o que adquirimos é um saber abrangente" ${ }^{, 162}$.

Dado seu caráter dialético, a experiência culmina na superação de toda experiência, o que, para Hegel, alcança-se no Absoluto. A essência mesma da experiência pensada no horizonte de sua negatividade, ressalta Gadamer, reside, todavia, no fato de poder ser superada. Sua realização não se consolida num conhecimento, porém, consuma-se por sua

\footnotetext{
159 “Experiência já não é, agora, o nome de uma espécie de conhecer. Experiência é agora a palavra do ser, na medida em que este é percebido a partir do ente enquanto tal. Experiência designa a subjetividade do sujeito. Experiência diz o que significa o 'ser-' na palavra ser-consciente [Bewußt-sein] e, justamente, de modo que só a partir deste 'ser-' é que se torna evidente e vinculativo o que permanece por pensar a palavra '-consciente"” (Id., ibid., p. 209-10).

${ }^{160}$ M. HEIDEGGER, O conceito de experiência em Hegel, p. 233.

${ }^{161}$ H.-G. GADAMER, $W M$, I, p. 360.

${ }^{162} I d .$, ibid., p. 359.
} 
constante referência a outras tantas experiências, por sua radical abertura a novas experiências. Diz ele:

“A verdade da experiência contém sempre a referência a novas experiências. Neste sentido a pessoa a que chamamos experiente é só alguém que se tornou no que é através de experiências, mas também alguém que está aberto a experiências. A consumação de sua experiência, o ser pleno daquele a quem chamamos experimentado, não consiste em ser alguém que já sabe tudo e que o sabe melhor do que ninguém. Pelo contrário, o homem experimentado é sempre o mais radicalmente não dogmático, que, precisamente por ter feito tantas experiências, está particularmente capacitado para voltar a fazer experiências e delas aprender. A dialética da experiência tem sua consumação não num saber concludente, mas nessa abertura à experiência que é posta em funcionamento pela própria experiência" ${ }^{\prime 163}$.

Nessas considerações gadamerianas, Hegel ressalta, diante do contexto da tradição filosófica ocidental, a importância e a necessidade da alteridade ou mesmo da negatividade como condição para constituição da consciência de si. Desmonta-se, assim, a concepção puramente instrumental e metodológica da experiência baseada na autonomia transcendental do sujeito, que, enquanto autoconsciência, planifica, controla e administra suas experiências, objetivando-as. O denominado homem experiente, a quem comumente chama-se sábio (phronimos), não é exatamente aquele que dispõe de um saber de validez universal ou mesmo exercita a capacidade soberana de predizer as coisas. Nesse ponto, Gadamer recupera na filosofia aristotélica uma indicação fundamental.

Aristóteles enquadra a experiência numa posição intermediária entre as percepções individuais e a generalidade do conceito ${ }^{164}$. Mesmo "surpreendentemente indeterminada", como assinala Gadamer, esta posição intermediária não confere à experiência uma deficiência. "A experiência não é a própria ciência, mas é um pressuposto necessário para ela. Ela tem de estar assegurada, isto é, as observações individuais devem mostrar regularmente os mesmos resultados. Só quando já se atinge a generalidade, da qual se trata na experiência, pode-se pôr a pergunta relativa à razão e, por conseguinte, o questionamento que conduz à ciência" 165 . Uma vez que a generalidade da experiência não corresponde nem à generalidade do conceito, nem à da ciência, o que há de fundamental nesta designação é sua realização da experiência com base em observações individuais sempre atualizadas.

\footnotetext{
${ }^{163}$ Id., ibid., p. 361.

${ }^{164}$ Gadamer refere-se às análises aristotélicas desenvolvidas no apêndice às Analytica posteriora (B, 19 [99s]), bem como no $1^{\circ}$ capítulo da Metafísica.

${ }^{165} I d .$, ibid., p. 356.
} 
Tal caráter está diretamente vinculado à essência da experiência propriamente dita, qual seja, um saber permanentemente adquirido. Nas palavras de Gadamer: "Nisso justamente se apóia a abertura básica da experiência para qualquer nova experiência - isso não somente no sentido geral da correção dos erros, mas ao fato de que a experiência é essencialmente dependente da constante confirmação, e, quando esta falta, ela converte-se necessariamente em outra diferente" ${ }^{\$ 166}$. Quando pensamos, todavia, a essência da experiência tomando como sua referência o plano do conhecimento científico, conceitual, reduzimos consideravelmente a universalidade de seu processo. Considerá-la isoladamente na perspectiva de seu resultado significa negar a ordem de sua referência constitutiva, cuja máxima constitui a abertura mediante rupturas, seu concreto campo de aplicação. Por isso denomina-se homem experimentado não aquele detentor de um método infalível, sob o mérito do qual dirige o curso dos acontecimentos, mas aquele que não é indiferente ao caráter imprevisível de toda experiência. Experiente, ou mesmo sábio, portanto, não é aquele que conduz seu comportamento respaldando-se em princípios abstratos, cuja validez restringe-se à particularidade de uma situação. Se como diz Aristóteles, a experiência (empeiria) possui o caráter de uma generalidade, essa não equivale nem à universalidade do conceito, nem tampouco às percepções repetidas, mas remete, fundamentalmente, à universalidade da finitude de toda experiência.

Em sua discussão com a dialética hegeliana, todavia, Gadamer sustenta que o projeto hegeliano de transformar a filosofia em ciência culminou em uma abstração. O problema é que Hegel concebe a experiência como condição para chegar-se ao saber absoluto, que nada tem de estranho fora de si. Dessa forma, "a dialética da experiência tem de culminar na superação de toda experiência, que se alcança no saber absoluto, isto é, na consumada identidade de consciência e objeto"167. O que fora pressuposto como necessário para a ciência, o movimento dialético da experiência, Hegel prescinde dele em sua essência - a natureza de sua abertura sempre a novas experiências.

Vista do ponto de vista de sua alteridade, acrescenta-se ainda um elemento qualitativamente novo a essa noção de experiência. Torna-se evidente que não se trata de uma experiência no sentido meramente informativo sobre alguma coisa que, aos poucos, foi-se conservando; bem pelo contrário, refere-se à experiência em seu todo, a seu acúmulo, de modo que seu exercício e habilidade integram a natureza histórica do homem.

\footnotetext{
${ }^{166}$ H.-G. GADAMER, $W M$, I, p. 357.

${ }^{167}$ Id., ibid., p. 361.
} 
Inevitavelmente o homem é um ser de experiências, na condição de não poder ser poupado destas. Ao adquiri-las, constantemente, essa abertura pressupõe, essencialmente, um desapontamento quanto às expectativas, ou mesmo experiências dolorosas. Conforme comumente se afirma ou se ouve, a experiência parece remeter-nos à dor do crescimento, ou mesmo à verdadeira compreensão de algo; por meio dela podemos retornar a algo para o qual anteriormente éramos cegos. A experiência em sua natureza está sempre contrariando expectativas. É, predominantemente, experiência dolorosa e desagradável, já que a negatividade e a desilusão são partes integrantes dela. Para ilustrar esse caráter conceitual da experiência, Gadamer refere-se à tragédia grega e, mais especificamente, à fórmula de Ésquilo - pathei mathos -, o aprender pelo sofrimento. Isto, porém, não significa que é só a partir de situações de danos e decepções dolorosas que conquistamos um saber melhor. Bem mais que isso, "o que o homem deve aprender pelo sofrer [...] é [...] a percepção dos limites de ser homem, a compreensão de que as barreiras que nos separam do divino não podem ser superadas" ${ }^{\prime 168}$. Isto corresponde a dizer que, antes de tudo, é pelo sofrimento - no caráter doloroso ou trágico do existir - que passamos a conhecer as próprias fronteiras da existência humana.

Como autêntico resultado da abertura da experiência, a consciência depara-se agora com os limites da finitude. A experiência é, essencialmente, "experiência da finitude humana [Erfahrung ist also Erfahrung der menschlichen Endlichkeit]"169. Primordialmente, isso significa que a condição de ser experiente torna-nos verdadeiramente conscientes de nossa própria finitude, dos limites de toda antecipação, bem como do caráter de insegurança de todos os nossos planos. O que a experiência, em sua natureza mais íntima, nos revela é o testemunho de que não somos senhores do tempo, já que nossa finitude sempre nos remete à abertura de novas experiências. Conforme vimos anteriormente, a consciência de nossa própria finitude é uma consciência trágica da experiência humana, já que esta última tem de sempre ser adquirida, e disso não pode ser poupada. Assim, é porque nos sabemos finitos e limitados em nossa capacidade de poder fazer e na elaboração de nossos planejamentos racionais que nos abrimos a outros horizontes e, conseqüentemente, às expectativas futuras. $\mathrm{O}$ reconhecimento de nossa finitude faz ainda da verdadeira experiência a experiência de nossa própria historicidade. Enquanto ser de experiência que atua e age na história, o homem

\footnotetext{
${ }^{168}$ Id., ibid., p. 362-3.

${ }^{169}$ Id., ibid., p. 363.
} 
adquire, através desta, uma intuição de futuro, por meio da qual se mantém sempre renovada a abertura a novas expectativas.

Ora, mas em que medida a finitude, na condição de caráter essencial da experiência hermenêutica, conduz-nos, necessariamente, a uma abertura à alteridade? Se, como ressalta Gadamer, a consciência está condicionada pelo princípio de efetuação histórica (Wirkungsgeschichte) - posteriormente desenvolvido em sua significação conceitual -, não resultaria daí a impossibilidade de manter-se aberta para todas as novas experiências? Numa perspectiva crítica, Claus von Borman ${ }^{170}$ - cuja crítica foi devidamente aceita por Gadamer identifica nesta reflexão sobre a experiência hermenêutica uma notável ambigüidade. "Com efeito, uma hermenêtica que radicalize a finitude terá de reconhecer que um certo bloqueio pertence, seguramente, à experiência hermenêutica. Sua insistência nos preconceitos condicionantes e condicionados do compreender inclui aquilo que nem em todos eles está à livre disposição. A consciência, por estar aberta, quer dizer, desperta para o seu mundo, não está aberta para todas as perspectivas" ${ }^{\prime 171}$.

Apresentada a elucidação sobre a natureza da experiência, resta ainda para Gadamer caracterizar, a partir da própria concepção histórico-dialética de experiência, a experiência hermenêutica propriamente dita. Esta tem a ver com aquilo que deparamos como tradição e que, portanto, tem de ser experimentada. Não, todavia, como um acontecimento que, vindo de longe, é reconhecido pela experiência e controlado por ela; a tradição é, antes de tudo, linguagem, isto é, "fala por si mesma como faz um tu"172. Situando-nos nela, sua compreensão dá-se como uma experiência essencialmente lingüístico-dialógica. Uma análise da experiência hermenêutica, cuja especificidade reside numa relação eu-tu, possui um caráter diferencial. Segundo Gadamer, do mesmo modo que se dá o vínculo do eu com o $t u$, verificase também nossa relação lingüística com a tradição. $O$ texto com que deparamos sob a forma de um tu, diz Gadamer, não pode ser tomado como uma simples manifestação, pois a referência para sua compreensão concentra-se, pelo contrário, no fato de este constituir-se como um conteúdo de sentido (Sinngehalt) significativo de um $t u$, independentemente de opiniões de ordem pessoal acerca dessa relação.

Nesse sentido, ao correlacionar aquilo que é herdado do passado com a relação eu-tu, Gadamer pretende ressaltar que, por meio do texto, esta herança, ao se dirigir a um leitor,

\footnotetext{
${ }^{170}$ C. VON BORMANN, Die Zweideutigkeit der hermeneutischen Erfahrung, citado em J. GRONDIN, Introducción a Gadamer, p. 185.

${ }^{171}$ J. GRONDIN, Introducción a Gadamer, p. 185-6.

${ }^{172}$ H.-G. GADAMER, WM, I, p. 364.
} 
interpela-o, buscando sustentar com ele uma relação de reciprocidade ${ }^{173}$. É tanto necessário deixar que o texto fale, quanto é fundamental que o leitor mantenha-se aberto ao texto. Ora, esta autêntica abertura está em conexão com a verdadeira experiência ${ }^{174}$ dialética, em cuja estrutura - eu-tu - o eu e o outro, exercitando suas possibilidades de experimentar, nivelam-se e são afetados no encontro.

Trata-se de um fluxo que não tem como fim a objetificação - o tu não é um objeto. A experiência eu-tu revela-se, pois, como uma experiência moral, na medida em que busca a específica compreensão do outro. Não podemos compreender o outro como qualquer outro objeto que se ponha no campo de nossa experiência. Mesmo em nome de um possível "conhecimento de pessoas", cairíamos no risco de prendermo-nos a uma compreensão objetiva de elementos típicos, mediante a observação de seu comportamento. "É uma pura ilusão ver no outro um instrumento completamente dominável, manejável” ${ }^{1175}$. Desse confronto resultaria uma relação em que o eu não se sentiria afetado pelo $t u$, limitando-se apenas a apreender, metodologicamente, regularidades do seu comportamento. De uma outra forma, a experiência do $t u$ nos conduziria a reconhecê-lo como pessoa. É uma relação reflexiva em que um pretende conhecer por si a pretensão do outro, e com isso eles afetam-se mutuamente e buscam, nessa dialética da reciprocidade, o próprio reconhecimento de si.

No momento o que queremos destacar como importante para a caracterização da experiência hermenêutica, a partir dessa relação eu-tu, é precisamente a especificidade de seu caráter histórico. "No terreno hermenêutico o correlato dessa experiência do tu é o que se costuma chamar de consciência histórica [historische Bewußtsein]",176. Isto porque a noção de consciência histórica ao nos remeter a idéia de alteridade, o faz sob a forma da relação eu-tu. É pois desse modo que a especificidade dessa relação está diretamente relacionada com aquilo que nos deparamos com a tradição Se a alteridade é o passado, essa consciência busca compreendê-lo no seu conteúdo de sentido, no seu caráter histórico único. Tal procedimento,

\footnotetext{
${ }^{173}$ De forma contrária, sustenta Gadamer, aquele que compreende a tradição de forma objetiva e metódica, tomando-a, desta forma, livremente como objeto, não é afetado por ela. A certeza com respeito a seu conteúdo é então adquirida de forma metódica e objetiva.

${ }^{174}$ Como verdadeira experiência a hermenêutica entende aquela que afeta a quem experimenta. O outro sempre será o tu nunca cercado pelo eu, mas sempre o afetando, e vice-versa. Aquele que é afetado e experimenta nunca sai ileso dessa experiência. Algo, por sua vez, afeta-nos autenticamente quando não se põe para nós como objeto de nossa manipulação e de nosso controle, escapando, assim, de nossa previsão, e de cuja inteireza não pudemos nos prevenir. Diz Gadamer: "Escutar o outro não significa simplesmente realizar às cegas o que o outro quer. Ao que é assim se chama submisso. A abertura para o outro implica, pois, o reconhecimento de que devo estar disposto a deixar valer em mim algo contra mim, ainda que não haja nenhum outro que o vá fazer valer contra mim" (H.-G. GADAMER, WM, I, p. 367).

${ }^{175} I d$., ibid., p. 365.

${ }^{176}$ Id., ibid., p. 366.
} 
no entanto, não se apóia na objetividade, nem tão pouco, com vistas a uma pretensão especulativa, ultrapassa o próprio condicionamento histórico e o domínio dos preconceitos aos quais a consciência está necessariamente submetida.

Da mesma forma que na relação eu-tu subsiste uma relação de reciprocidade, reflexividade, de mútua abertura, assim também a consciência histórica, ao deparar com a tradição, deve buscar compreendê-la sem prescindir de suas próprias pretensões, de sua historicidade propriamente dita. $\mathrm{Na}$ experiência hermenêutica o que se põe como mútua abertura não nos proporciona apenas um simples reconhecimento da alteridade do passado, mas revelação de que a tradição tem algo a me dizer. Por isso, a experiência hermenêutica, enquanto experiência da consciência histórico-efetiva (Wirkungsgeschichte), ao nos confrontar com um horizonte de abertura, "permite que a tradição converta-se em experiência e mantenha-se aberta à pretensão de verdade que lhe vem ao encontro nela"177.

Pode-se com isso afirmar que a abertura da experiência hermenêutica enquanto essencialmente uma experiência da finitude humana apresenta um caráter essencialmente antidogmático. Já não se reporta à figura de "um em si" incomunicável, mas, fundamentalmente, ao ser de como algo se auto-apresenta. Em sua natureza constitui um remeter-se à alteridade de possíveis experiências, ao horizonte que, vendo além de nós mesmos, inclina-se a experimentar, até mesmo, aquilo que nos ameaça.

Retomando-se a estrutura de Verdade e método, podemos afirmar que a primeira parte dessa obra apresenta uma reflexão sobre a abertura da experiência hermenêutica representada pela experiência da arte; uma abertura que, como diz Portocarrero, "[...] prepara [...] a disponibilidade humana para toda uma relação ao ser a partir de um enraizamento lingüístico e concreto no mundo. Contraria, por isso, frontalmente o modelo epistemológico moderno de abertura humana, cujo lema era, desde a redução baconiana da experiência, a experimentação: conhecer para melhor dominar," ${ }^{\prime 178}$. Reduzida à sua dimensão puramente vivencial, a consideração estética pós-kantiana é ultrapassada pelo próprio alargamento da noção de experiência. A abertura humana à arte, bem pelo contrário, implica um repúdio ao caráter de coisa e objeto, resultante de uma conformação subjetiva imposta pelos parâmetros da consciência reflexiva. É, pois, dessa forma que "todo encontro com a linguagem da arte é o encontro com um acontecer não concluído, e forma, por sua vez, parte deste mesmo. Há que

\footnotetext{
${ }^{177}$ Id., ibid., p. 367.

${ }^{178}$ M.L. PORTOCARRERO, O preconceito em H.-G. Gadamer, p. 93.
} 
tornar isso válido contra a consciência estética e sua neutralização do problema da verdade" 179 .

Naquilo que se segue ao longo do desenvolvimento de nosso trabalho, a análise sobre o caráter paradigmático da arte como reivindicação de verdade tem a partir da caracterização da experiência hermenêutica a abordagem específica de seu tratamento. Primordialmente o que possibilita uma reflexão hermenêutica sobre o fenômeno do belo artístico é sua radical possibilidade de ser investigado e reconhecido como experiência essencialmente hermenêutica, antes mesmo de sua especulação como experiência de verdade. A arte é experiência hermenêutica, e, enquanto tal, sua análise remete-nos aos elementos essenciais que perfazem a natureza do conceito de experiência hermenêutica. Considerando sua essencial abertura, a experiência da arte será então submetida à indagação sobre seu modo ser - caráter ontológico -; enquanto experiência de finitude e de efetuação histórica (Wirkungsgeschichte), será tomada na qualidade de experiência da consciência histórica e no caráter de sua atualidade; e, por último, ressaltaremos sua abordagem enquanto experiência de linguagem, dialógica. Do ponto de vista hermenêutico, a experiência da arte sobressai como uma presença sob a forma de licença poética, cujo movimento de representação instaura uma específica declaração de verdade atualizada no tempo e celebrada na história.

\subsection{A experiência ontológica da arte: Da apresentação lúdica à representação simbólica}

Acompanhando-se o itinerário desenvolvido na primeira parte de Verdade e método, torna-se bastante claro que, da identificação dos limites impostos pelo processo de subjetivação estética, sobretudo a partir de Kant, segue-se o propósito de retomar a questão da verdade da arte por meio de uma análise ontológica. Superar a subjetivação kantiana e póskantiana da estética, que por sua vez assegurou essa herança estetizante das noções de gosto e gênio, tornou-se condição para o reconhecimento da pretensão de verdade na experiência artística. De fato, é a pretensão objetiva da ciência moderna que sentencia a experiência

${ }^{179}$ H.-G. GADAMER, WM, I, p. 105. 
estética a entender-se puramente subjetiva, como se esta estivesse essencialmente confinada às vivências subjetivas de um indivíduo.

Trata-se então de investigar de que forma Gadamer contesta a tese de que a especificidade da experiência artística neutraliza os parâmetros possessivos do método, do rigor e do conceito, distanciando-se, assim, do modelo de experiência de verdade característico da modernidade científica pós-kantiana. Sustentar, portanto, o caráter referencial da experiência da arte a partir do qual se anuncia uma forma de verdade resulta numa ponderação ontológico-hermenêutica sobre esta. Em outras palavras, uma análise hermenêutica sobre o fenômeno da arte implica, necessariamente, sua análise ontológica ${ }^{180}$, na compreensão de seu modo de ser. Eis a condição de possibilidade não só de retomar a função de verdade inerente a esse fenômeno, mas também de pensar a atualidade do belo ${ }^{181}$. Portanto, uma investigação hermenêutica sobre a questão da verdade da arte aponta não só para a caracterização de seu modo de ser, como também para o problema de legitimação que essa específica pretensão de verdade suscitou na propagação histórica das criações poéticas. Inevitavelmente, sustenta Gadamer, o fenômeno da compreensão conduz-nos à via de regresso à tradição, convocando-nos - quando se trata da exposição de um tema - a um questionamento histórico-conceitual à luz de um diálogo entre o antigo e o moderno. Nossa exposição, por conseguinte, busca desenvolver e articular esses dois momentos de análise.

Concentremo-nos, inicialmente, na explicitação ontológica da arte, na estrutura de seu modo de ser. O que Gadamer propõe é pensar a experiência da arte enquanto experiência de finitude, experiência humana. Embora a base antropológica dessa experiência implique o

\footnotetext{
${ }^{180} \mathrm{O}$ que Gadamer tem em vista aqui é a abordagem da ontologia a partir de Heidegger. Não se trata simplesmente de um estudo dos entes, mas de uma Fundamentalontologie, que vislumbra o sentido e significado do ser a partir da análise do Dasein. Neste caso, o que está em questão é devolver ao homem sua relação primordial com o ser, procurando não apenas o ser dos entes, mas o ser em sua essência. Se em Sein und Zeit a elaboração da questão do sentido do ser - a hermenêutica do ser-no-mundo - move-se do Dasein, enquanto compreensão do ser, para o ser em seu sentido, na segunda fase do pensamento heideggeriano o ser já não constitui um produto do pensamento. A chamada reviravolta (Kehre) instaura uma inversão do movimento de modo que agora se parte do próprio evento do ser, do ser para a hermenêutica do Dasein. Posto isto, a reflexão ontológica à qual Heidegger submete a obra de arte - e na qual Gadamer baseia-se para refleti-la como experiência de verdade - pensa-a como domínio de revelação e abertura, do mesmo modo que o Dasein assim fora considerado. A análise ontológica sobre a arte que aqui temos em mente é, portanto, aquela cuja pergunta pela arte converte-se na pergunta pela sua essência, pelo seu modo de ser - o que é e como é uma obra de arte? (Cf. M. HEIDEGGER, Der Usprung des Kunstwerk).

${ }^{181}$ A atualidade do belo (Die Aktualität des Schönen) apresenta-se como uma versão elaborada do curso ministrado por Gadamer na Universidade de Salzburgo em 1974 sob o título "A arte como jogo, símbolo e festa". Trata-se de uma investigação sobre o problema de legitimação da verdade na arte moderna, a partir dos fundamentos conceituais de sua hermenêutica filosófica, como, por exemplo, o fenômeno da compreensão, a noção de verdade (aletheia), além de uma base antropológica necessária para a explicitação ontológica da experiência artística, da qual fazem parte o jogo, o símbolo e a festa.
} 
desenvolvimento das categorias de jogo, símbolo e festa, no momento nos deteremos nas duas primeiras diretivas conceituais, quais sejam, o lúdico e o simbólico.

O ponto de partida para o cumprimento de tal tarefa é o conceito de jogo (Spiel). Nossa exposição atém-se, inicialmente, a uma apresentação de caráter genérico dessa categoria e, posteriormente, contempla a relação específica entre jogo e experiência artística.

Ao caráter estreito da determinação transcendental kantiana do gosto e suas ressonâncias subjetivas, inerentes à concepção de vivência artística, Gadamer contrapõe o fenômeno do jogo, cuja natureza fluida revela-o como uma estrutura não entitativa, nem objetiva. Eis o novo fio condutor de explicitação hermenêutica da arte, na medida em que possibilita sua explicação ontológica. Analisar o fenômeno do jogo é, antes de tudo, ter presente a noção que essa palavra exprime, no horizonte da língua e da cultura. Embora esse não seja nosso propósito, convém lembrar que estamos diante de uma categoria cuja noção não advém de um pensamento lógico-científico, mas do âmbito de uma linguagem criadora repleta de diferenciações.

Se nos dispuséssemos a desenvolver um exame lingüístico sobre a noção de jogo, identificando as raízes conceituais desse termo, a amplitude de suas designações seria muito vasta e proporcional ao próprio universo das línguas e das diferenciações culturais, no modo pelo qual elas, distintamente, conceberam esse elemento espiritual básico da vida ${ }^{182}$. Como bem observa Huizinga, a concepção de um conceito geral de jogo foi, em muitas culturas, deveras tardia, se comparada à sua função e a seu desempenho enquanto atividade. Isso pode ser ilustrado até mesmo pelo fato de que, desde muito cedo, na vida dos povos gregos, as competições sagradas e profanas haviam assumido lugar e valor de grande importância. Tal era o peso da função cultural das competições, que essa atividade tornou-se integralmente habitual, de modo que as pessoas até deixaram de ter consciência de seu caráter lúdico. Nesse sentido, em algumas línguas, a denominação do jogo assume diversas expressões para identificar sua atividade lúdica. No grego, por exemplo, existem três palavras para designar o jogo, em geral: aquilo que é próprio da criança $(\pi \alpha \downarrow \delta \imath \alpha)$, o que não estando limitado a jogos infantis indica um brincar e, de acordo com suas variações, todas as espécies de formas

\footnotetext{
${ }^{182}$ Influenciando notadamente a concepção de jogo em Gadamer, Johan Huizinga, em Homo ludens (Homo ludens - vom Ursprung der Kultur im Spiel, 1938), desenvolve uma análise sobre o jogo como um fator fundamental presente em tudo o que acontece no mundo e a partir do qual a civilização desenvolve-se. Para além de um fenômeno biológico, o jogo é um fenômeno essencialmente cultural. Em A atualidade do belo (Die Aktualität des Schönen) a perspectiva de abordagem do conceito de jogo é, desde o início, a cultura humana, na qual os elementos lúdicos sempre estiveram presentes. "O jogo é uma função elementar da vida humana" (H.-G. GADAMER, $A k S c h$, in: $G W, 8$, p. 113).
} 
lúdicas $(\pi \alpha \downarrow \delta 1 \alpha$ ') e o termo ' $\alpha \theta v \rho \omega$, ` $\alpha \theta v \rho \mu \alpha$, mais voltado às idéia de futilidade. Além desses, há um termo grego que se refere àquilo que, comumente, chamamos de concursos ou competições; domínio esse designado pela palavra ` $\alpha \gamma \varpi v$. Há aqui uma distinção lingüística entre jogo e competição, sobretudo porque no termo ` $\alpha \gamma \varpi v$ não está expresso o elemento da não-seriedade e o fator lúdico propriamente dito. No latim, por sua vez, o termo ludus abarca a totalidade das designações do jogo, abrangendo desde jogos infantis, competições, recreações, representações e jogos. Seu caráter etimológico característico é, pois, o fator da não-seriedade e da ilusão. Mas a noção de jogo não se limita à idéia de atividade ou movimento ligeiro. Na língua alemã, seu termo correlato é Spiel, spielen, e seu uso é inteiramente diferenciado. Refere-se a jogo, porém, não apenas enquanto execução lúdicoesportiva (den Ball spielen), prática de um jogo (spielen ein Spiel), que tem o mesmo sentido de "Spiel treiben", mas também a um jogo de cores (Spielfarbe); indica uma brincadeira (Spielerei), mas também uma execução de música (Gitarrespielen), representação teatral peça - (Schauspiel), atuação artística (Schauspieler), ou até um envolvimento (im Spiel sein) ou mesmo um jogo de paixão (Passionspiel), jogo de mistério (Mysterienspiel) ou jogo de intrigas (Spielintrige). Semelhante abrangência encontramos também na língua inglesa e francesa no tocante às palavras play e to play e jeu e jouer, respectivamente. Suas significações apresentam, dentro do domínio amplo de suas referências, o sentido de jogar, brincar, movimento, a representação ou desempenho de um papel (no inglês play a part, no francês jouer um rôle), o manejo de instrumento musical (player piano; jouer du violon), etc.

Nessa diferenciação de sentidos e significações, o jogo, além de um reflexo psicológico que se expressa por atitudes e gestos, é uma função significante e social que se manifesta por uma específica atividade de movimento, cuja natureza essencial é a fluidez, a presença não material. Apenas dessa forma, tomando-o em sua significação primária, torna-se possível identificar os laços que unem a arte a esse solo instintivo, no qual aquela tem sua origem.

Convicto da necessidade de uma fundamentação hermenêutica da experiência estética a partir da experiência lúdica, Gadamer imprime com precisão crítica sua compreensão sobre o jogo, vislumbrando identificar em sua natureza o próprio modo de ser da experiência artística. Nesse sentido, afirma:

\footnotetext{
"Tomamos para isso como primeiro ponto de partida um conceito que desempenhou na estética um papel de maior importância: o conceito do jogo. Importa, no entanto, libertar este conceito do significado subjetivo que tem em Kant e Schiller e que domina toda a
} 
nova estética e antropologia. Quando, no contexto da experiência da arte, falamos de jogo, jogo não significa nem o comportamento, nem o estado de ânimo daquele que cria ou desfruta e de modo algum a liberdade de uma subjetividade, que no jogo confirma-se a si mesma, mas sim o modo de ser da própria obra de arte" ${ }^{, 183}$.

Nas Cartas sobre a educação estética da humanidade (Über die Ästhetische Erziehung des Menschen) é nítida a influência que as reflexões kantianas sobre o juízo estético exerceram sobre o pensamento de Schiller. Em Kant, lembremos mais uma vez, os juízos sobre o prazer estético manifestam-se quando a forma de um objeto, representado por nossa imaginação, parece-nos "funcional" ou adequada à nossa mente, sem que nisso intervenha a explicitação de conceitos. Para tanto, na contemplação estética há uma concordância entre sensibilidade e imaginação, de modo que elas entram em um jogo harmonioso com a inteligência, mas sem que haja a interferência conceitual. Se o prazer estético é possível, isso é uma resultante do jogo livre de nossas faculdades mentais, uma vez que possibilita ao gosto julgar o objeto como belo. O jogo mantém-se como propriedade da subjetividade. Desenvolvendo em larga medida as idéias kantianas, essa concepção de jogo estético introduzida por Kant assume na obra de Schiller o caráter de uma práxis educativa e política. Para Schiller, só a visão do homem íntegro é capaz de constituir um estado moral. Para isso, o que lhe falta não é inteligência e entendimento, mas, sobretudo, o apoio dos impulsos, a vitalidade que assegura a eficácia do conhecimento para a vida. Uma indagação filosófica sobre a estrutura da alma humana implica, em seu ser, um duplo impulso, o sensível material e sentimental - e o formal, em que reinam os juízos universais e as normas universais da moralidade. Recuperar a unidade da natureza humana, dada a oposição destes dois impulsos, com vistas a assegurar-lhe integridade só se torna possível por meio do impulso lúdico ${ }^{184}$. É só no estado lúdico que o homem tornar-se-ia capaz de subordinar reciprocamente o desejo natural e o rigor da razão, desdobrando simultaneamente a dupla natureza humana: a variação e a unidade, a sucessão temporal e o eterno. Desse modo, embora Schiller tenha ultrapassado o plano subjetivo do gosto, tipicamente kantiano, deslocando suas investigações para o horizonte do objeto, a obra de arte propriamente dita, sua reflexão sobre o jogo, segundo Gadamer, permanece ainda fixa a um caráter essencialmente subjetivo.

\footnotetext{
${ }^{183}$ H.-G. GADAMER, $V W$, I, p. 107.

${ }^{184} \mathrm{Na}$ "Carta XIV", diz Schiller: "O impulso sensível quer que haja modificação, que o tempo tenha conteúdo; o impulso formal quer o tempo negado, para que não haja modificação. $\mathrm{O}$ impulso em que os dois atuam juntos (seja-me) permitido chamá-lo impulso lúdico [...] portanto, aspira a suprimir o tempo no tempo, a ligar o devir ao saber absoluto, a modificação à identidade" (F. SCHILLER, A educação estética do homem, p. 74).
} 
Ora, conforme vimos anteriormente, ao longo da análise sobre a crítica da consciência estética, a obra de arte não pode ser considerada como um objeto posto diante de um sujeito, pois é ela mesma que se constitui como o "subjectum" verdadeiro da própria experiência da arte. $\mathrm{O}$ que parece ser relevante do ponto de vista daquilo que fundamenta essa questão é que a experiência estética não pode mais ser tomada como uma experiência da qual nos apresentamos como seus donos e senhores. Por isso o que possibilita o seu acontecer - e aqui, de modo específico, referimo-nos à experiência da arte - é o fato de nos deixarmos levar, atraídos por seu jogo. Esse deixar-se levar pela metáfora do jogo mostra-se como fundamento hermenêtico para recuperar a verdade da arte.

O que constitui a natureza do jogo é que ele tem uma existência independente daqueles que jogam, já que não são mais os jogadores o sujeito do jogo, mas o próprio jogo. A subjetividade passa a desempenhar um papel de caráter inteiramente secundário. Por meio dos jogadores, o jogo ${ }^{185}$ apenas ganha sua representação (Darstellung). O que possibilita a compreensão de sua natureza não é uma reflexão subjetiva por parte de quem joga, mas o questionamento que indaga pelo modo de ser do jogo. Eis o horizonte ontológico-especulativo a partir do qual Gadamer elucidará o modo de ser da obra de arte. Aqui, o jogo estaria a serviço da verdade.

Em seu sentido mais amplo e originário, o jogo constitui-se como "o vaivém de um movimento o qual não está fixado em nenhum alvo, no qual termine" ${ }^{\text {,186 }}$. Os jogadores achamse envolvidos por esse movimento que se repete de forma contínua, mas sem que cumpram ou obedeçam a qualquer objetivo ou fim que lhe confira sentido. O próprio uso lingüístico do termo, na amplitude de seus significados metafóricos, como vimos anteriormente, indica uma forma de movimento de caráter autotélico. O jogo é, em si, a execução do próprio movimento enquanto tal. Seu desenrolar-se como jogo (sich abspielt) implica a consumação do próprio movimento sem que subsista um sujeito fixo que esteja e que se porte como se ali estivesse jogando ${ }^{187}$. Daí habitualmente se dizer que algo se joga ou está em jogo sob a forma de

\footnotetext{
${ }^{185}$ No sentido de ultrapassar o caráter subjetivo do conceito de jogo, Gadamer desenvolve-o a partir de uma análise fenomenológica, apoiando-se em meditações contemporâneas acerca desse conceito. São reflexões que nele reconhecem uma fundamentação antropológica de uma experiência de estar-no-mundo. Para exemplificálas, seguimos F.J.J. BUYTENDIK, Wesen und Sinn des Spiels, 1993; J. HUIZINGA, Homo ludens; E. FINK, Le jeu comme symbole du monde.

${ }^{186}$ H.-G. GADAMER, $W M$, I, p. 109.

${ }^{187}$ Gadamer lembra-nos a advertência feita por Huizinga, em Homo ludens, quanto ao fato de que, embora no alemão exista a expressão "ein Spiel treiben" (praticar um jogo), bem como no holandês, "een spelletje doen”, é o verbo "spielen" que melhor e realmente corresponde a esse movimento, cuja ação e caráter são especiais e autônomos. O jogar não diz respeito a um fazer, de modo que, para melhor expressar o gênero desse termo, devemos repetir no verbo o conceito que o substantivo contém.
} 
impulso livre. Ora, esse movimento que corresponde ao primado do jogo ganha um novo esclarecimento, ressalta Gadamer, se observado em seu sentido mediano. Em seu caráter autotélico, trata-se de um movimento lúdico que transcorre espontaneamente, sem a exigência de esforço - uma vez desprovido de finalidade e de intenção -, assemelhando-se, dessa forma, ao movimento inerente à natureza ${ }^{188}$. A leveza inerente à estrutura de ordenação do jogo solicita da parte de quem joga uma entrega sob a forma de um transcender as necessidades imediatas da vida, um libertar-se do dever de iniciativa e decisão, imposições características da existência cotidiana.

Além disso, esse movimento não corresponde a um "jogar-para-si-somente" (kein Für sich-allein-Spielen). Isto porque "para que seja um jogo pode até não ser necessário que haja um outro jogando, mas é preciso que sempre haja ali um outro com o qual o jogador jogue e que, de si mesmo, responda com um contra-lance ao lance do jogador" ${ }^{\text {"189 }}$. É nesse sentido que a essência do comportamento lúdico revela-se, na dinâmica do próprio movimento, o verdadeiro sujeito do jogo. Quando Gadamer afirma, todavia, que, fundamentalmente, "todo jogar é um ser jogado" ${ }^{190}$ (Alles Spielen ist ein Gespielt werden), além da noção de movimento, o que parece estar em questão é o próprio espaço livre do jogo. $\mathrm{O}$ ato de jogar implica, também, ser determinado por uma escolha; afinal, alguém quer jogar e, por conseguinte, manter-se num espaço limitado e livre, no qual os jogadores estão inseridos, uma vez arrastados pelo fascínio, pela surpresa e pelo risco, inerentes à seriedade do próprio jogo. Convém ainda assinalar que esse movimento lúdico aplica-se não apenas aos jogadores em situação, mas também aos espectadores, que, por sua vez, sempre jogam, participam do jogo na medida em que se mantêm atentos à dinâmica e ao intercâmbio das jogadas, inserindo-se na realidade lúdica.

\footnotetext{
${ }^{188}$ Esse movimento condiz com o próprio espaço do jogo, elemento esse que, segundo Gadamer, é fundamental para pensar-se a questão da arte. Tendo esse movimento a forma de um automover-se, Gadamer afirma que tal observação já fora feita por Aristóteles. "O automovimento é característica básica do que está vivo. Tal já descreveu Aristóteles [...] O que é vivo tem o impulso do movimento em si mesmo, é automovimento" (H.-G. GADAMER, $A k S c h$, in: $G W, 8$, p. 114). Por outro lado, é tendo em vista o movimento como modo de ser essencial do jogo que Gadamer vai assinalar seu sentido fundamental, característica essa nuclear para a relação jogo/arte. Diz Gadamer: "O fato de o modo de ser do jogo encontrar-se tão próximo da forma de movimento da natureza permite, porém, uma importante conclusão metódica. É evidente que não é assim, que os animais também brincam (spielen, em alemão, significa tanto jogar como brincar, tocar um instrumento ou representar teatro etc.) e que até se pode dizer, num sentido figurado, que a água e a luz brincam. Ao contrário, poderíamos dizer do homem que ele também brinca [spielt]. Também seu jogar é um acontecimento da natureza. Também o sentido de seu jogar, justamente por ele ser, e na medida em que é, natureza, é um puro representar-se a si mesmo. É assim que, no final, torna-se praticamente sem sentido diferenciar, nesse campo, o uso próprio e o metafórico" (id., WM, I, p. 110-1)

${ }^{189}$ Id., ibid., p. 111.

${ }^{190}$ Id., ibid., p. 112.
} 
Ora, quando partimos para analisar a natureza e o significado do jogo, a relação entre comportamento lúdico e seriedade parece ser, irredutivelmente, de oposição, como afirma Huizinga. Num exame mais cuidadoso, no entanto, "verificaremos que o contraste entre jogo e seriedade não é decisivo, nem imutável. É lícito dizer que o jogo é a não seriedade, mas esta afirmação, além do fato de nada nos dizer quanto às características positivas do jogo, é extremamente fácil de refutar" ${ }^{191}$. Trata-se de uma relação não de contrários, mas de uma identidade específica. A determinação do jogar ${ }^{192}$ implica um comportamento diferenciado em que o ser humano livra-se das tensões inerentes a seu cotidiano, transformando os fins de seu comportamento em simples tarefas. Jogar é vincular um comportamento aos fins aparentes do jogo.

Não se trata, pois, de uma mera realização de tarefas, no sentido de uma conduta ou esforço orientado a realizar seus fins, mas da organização e configuração de seu próprio movimento; neste reside o fim do jogo. Afinal, para aquele que não leva o jogo a sério, dizemos que está violando as regras, como se o jogo desfrutasse de uma autonomia própria e regras específicas.Também por isso é que não tem sentido falar-se em jogo autônomo dos jogadores, mas sim em autonomia do jogo, isto é, da primazia do jogo diante da consciência do jogador. Só na medida em que a subjetividade submete-se à lei do jogo é que ela realmente joga. Sob esse ponto de vista, mesmo parecendo redundante, é correto afirmar que aquilo que registra a peculiar leveza do comportamento lúdico é o caráter especial de sua tarefa, ou seja, o entregar-se à tarefa do jogo (Spielaufgabe) é desde sempre um pôr-se em jogo (Sichausspielen) ${ }^{193}$. A seriedade do jogo sustenta-se na especificidade de sua tarefa. Em sua natureza, o jogo implica a “'auto-apresentação' [Selbstdarstellung] do próprio movimento do

\footnotetext{
${ }^{191}$ J. HUIZINGA, Homo ludens, p. 10. Huizinga ressalta que, além do jogo, outras categorias são facilmente contrapostas à seriedade, entre as quais, o riso, o cômico.

192 "O espaço lúdico em que se desenrola o jogo (brincadeira) será, ao mesmo tempo, mensurado de dentro pelo próprio jogo (brincadeira) e limita-se bem mais através da regulamentação, que determina o movimento do jogo, do que através daquilo contra o que ele se choca [...] os limites do espaço livre [...]" (H.-G. GADAMER, WM, I, p. 112). No tocante à delimitação do campo do jogo, Gadamer refere-se à análise feita por Huizinga, quando este se reporta ao lugar do jogo no âmbito do sagrado. Nesse sentido, o mundo do jogo, em oposição ao mundo dos fins, é um mundo fechado, sem que haja transições e intermediações entre ambos. O jogo constituir-se-ia em um comportamento distinto do da vida comum e que possui um sentido próprio dentro de certos limites de tempo e espaço.

${ }^{193}$ Identifica-se aqui o caráter especial do jogo humano. De um lado, o exercício da razão, a aspirar conscientemente a fins, de outro, sua capacidade de burlar esses fins tendo em vista a própria configuração do movimento do jogo. "A qualidade humana do jogo humano reside em que, nesse jogo de movimentos, ordene e discipline, por assim dizer, seus chamados movimentos de jogo, como se tivessem fins; por exemplo, como quando a criança conta quantas vezes a bola pode bater no chão antes de escapulir-lhe das mãos" (id., $A k S c h$, in: $G W, 8$, p. 114). É a própria razão impondo-se como regra sob um fazer livre de objetivos.
} 
jogo [Spielbewegung $]^{194}$. O movimento do jogo constitui-se, assim, no próprio movimento de apresentar-se (sich darzustellen), e a essa atividade ele se limita. Partindo-se, no entanto, do pressuposto de que o jogo é um movimento de auto-apresentação, jogar significa então, também para os jogadores, alcançar nesta atividade seu próprio auto-apresentar-se. Dessa forma, jogar é permitir-se a tarefa lúdica do representar.

Assim, perguntamo-nos qual é o mérito dessa fenomenologia do jogo, do "ser jogado", para uma ontologia da obra de arte, no universo da problemática hermenêutica de Gadamer. E pensamos que é aqui, no significado dinâmico da apresentação (Darstellung), que parece estar, especificamente, o que justifica a importância desta categoria para a reconsideração da arte como experiência de verdade. Segundo Gadamer, o caráter lúdico da arte tem sua especificidade justificada pela significação do próprio representar, na medida em que, em seu horizonte de possibilidade, todo apresentar (Darstellen) implica, necessariamente, apresentar para alguém. Por isso, jogar é, desde sempre, um jogar junto, portanto, radicalmente inserir-se num movimento de participação. Convém, no entanto, ressaltar que, nessa relação de identidade jogo-apresentação ${ }^{195}$, os jogos não intencionam estes ou aqueles espectadores, mesmo quando diante destes.

O que perfaz a integridade do movimento da representação é a abertura (das Offensein) mesma para o espectador. "A apresentação [Darstellung] da arte, de acordo com sua natureza, é de tal maneira, que é para alguém, mesmo quando não há ninguém que sequer a ouça ou assista"196. Isso nos conduz a identificar a importante tese sustentada por Gadamer em Verdade e método: a obra de arte tem seu genuíno ser em sua apresentação (Darstellung); nesta a nossa participação mantém-se sempre requisitada. Dessa forma, o modo de ser da arte, ontologicamente, corresponde a seu representar. A poesia não pode ser distanciada de seu recital, da mesma forma que o espetáculo teatral não pode ser compreendido privando-o do seu pôr-se em cena. Para efeito e ilustração Gadamer dá ênfase, aqui, às artes transitórias,

\footnotetext{
${ }^{194}$ H.-G. GADAMER, $A k S c h$, in: $G W, 8$, p. 114.

195 Ao aprofundar sua análise fenomenológica sobre o jogo, assinalando-o, em sua essência, como autoapresentação, Gadamer também destaca o sentido de um fazer comunicativo, na medida em que o espectador, não sendo um simples observador, faz parte do próprio jogo. O propósito aqui parece ser mostrar o que justifica o caráter lúdico da arte - a arte ser pensada a partir do primado do jogo -, qual seja, a lei do movimento da representação. Gadamer então adverte para o fato de que as representações nem sempre se dão do mesmo modo e no mesmo sentido, como, por exemplo, a representação teatral (Schauspiel), a representação de culto (Kultspiel) e até a representação de uma criança que brinca com algo.

${ }^{196} I d ., W M, \mathrm{I}, \mathrm{p} .116$.
} 
como o teatro e a música, cujas apresentações e interpretações estão intimamente na dependência de seu acontecimento, de sua encenação ${ }^{197}$.

Em Verdade e método a categoria da representação (Darstellung) traz em sua formulação a insistência gadameriana em vislumbrar a realização ontológica que acontece na obra de arte; é por isso que nosso autor parte sempre dela. Representação aqui não é só de algo, mas também para alguém a quem esse ser adquire forma. É por esta razão que a representação comporta um processo ôntico de transformação.

Visto no caráter de sua generalidade, o que agora se torna necessário verificar é de que forma o jogo, na dinâmica de sua natureza, identifica o modo de ser próprio da arte. É em seu tornar-se arte, assinala Gadamer, que o jogo cumpre sua verdadeira realização. Trata-se aqui de seu processo ôntico de transformação em obra; na medida em que, nessa transmutação, esse movimento lúdico assume a autonomia de uma transformação em configuração ${ }^{198}$ (Gebilde) de caráter repetível e permanente, isto é a arte.

O propósito de Gadamer é a substituição do conceito de obra (Werk) pelo de configuração (Gebilde), pois apenas por meio deste último pode ser mais bem explicitado o modo de ser da experiência da arte. No tocante à determinação do ser da arte, o que, na expressão "transformação em configuração" (Die Verwandlung ins Gebilde), merece primeiramente destaque é o significado peculiar atribuído ao termo "transformação" (Verwandlung). O sentido que lhe é conferido não corresponde à significação dialética de "modificação"; daquilo que, ao modificar-se, permanece e fixa-se como o mesmo, mas sim a uma autêntica transmutação de algo que, “de uma só vez e em seu conjunto, torna-se uma outra coisa, de maneira que essa outra coisa, que é enquanto transformada, passa a ser seu

\footnotetext{
${ }^{197} \mathrm{Na}$ verdade, Gadamer quer aplicar esse modelo a todas as demais artes, até mesmo àquelas em que isso poderia parecer menos evidente, como a literatura ou mesmo a pintura. Assim, se todas as artes estão necessariamente destinadas a uma representação (Darstellung), uma expressão que bem definiria o seu específico sentido seria o termo interpretação. Na língua francesa, por exemplo, a expressão "artes transitórias" tem como correlato "artes de interpretação". Ao serem interpretadas, as artes têm seu ser, que é inerente a essa interpretação. Aqui o que se põe como fundamental não é a possível diferenciação entre as múltiplas interpretações e o original, o que nos permite algumas vezes afirmar que uma tal interpretação é mais ou menos moderna, ou mesmo que não faz justiça à obra original.

${ }^{198}$ A transformação do jogo em configuração (Gebilde) adquire em seu caráter de obra o sentido de "ergon" e não apenas "energeia", no modo pelo qual Aristóteles desenvolveu e destacou essa distinção clássica. "Ergon" é um termo grego que designa algo feito ou construído, mas que é, porém, usado pelos filósofos tanto no sentido de atividade, quanto no sentido de produto de atividade. Aristóteles, em suas especulações éticas, fala-nos, portanto, de atividades cuja finalidade (telos) é um produto - a saúde é o ergon da medicina -, e outras que têm como seu "telos" a própria atividade. Na Metafísica (105a), aperfeiçoa o conceito de "ergon" referindo-o ao "estar em atividade" (en-ergeia). Tal estado é a finalidade (telos) do ser, quer a atividade termine em um ergon externo ou não (F.E. PETERS, Termos filosóficos gregos, p. 79).
} 
verdadeiro ser, em face do qual seu ser anterior é nulo"199. A transformação, nesse sentido, não deixa subsistir a identidade daquilo que muda, mas, ao contrário, viabiliza uma verdadeira passagem à outra coisa. Com essa afirmação, Gadamer quer dizer-nos que tomar a arte como "Gebilde" significa compreendê-la não do ponto de vista de suas diferenciações subjetivas, das identidades daqueles que jogam, seja como criadores, atores e espectadores, mas daquilo que, enquanto configuração que está aí, é jogado, representado por estes. Desse sentido de transformação não se segue a transferência a um outro mundo, trata-se apenas de trazer à luz aquilo que ordinariamente se retrai, transformar em seu pleno sentido, transformar no verdadeiro. Por meio de uma transformação aquilo que é representado e mostra-se, evidentemente, como algo distinto, adquire uma figura, uma idealidade, quer dizer, põe-se como uma obra de arte.

Nesse sentido, Gadamer apresenta o exemplo de um espetáculo dramático que não tolera qualquer tipo de comparação com a realidade e, tão-somente a partir de si, constitui a expressão de uma verdade superior ${ }^{200}$. Na representação do jogo ilumina-se o que outrora, em ocasiões ordinárias, permanecia encoberto. Conforme acrescenta Dastur:

\begin{abstract}
"A metamorfose de que aqui fala Gadamer é precisamente esta que nos faz entrar no verdadeiro, a representação pelo jogo fazendo emergir o que é, e, assim, o suporte ao jogo. Uma tal metamorfose consiste em tomar o conjunto da realidade como um círculo fechado de significações no qual tudo é realizado completamente, no momento em que aquilo que caracteriza o ordinário da realidade é precisamente o incerto do futuro e a pluralidade de possibilidades que se delineia nele"201.
\end{abstract}

Compreender a transformação em configuração (Gebilde) como o jogo da arte é, pois, entender a realidade a partir da própria realidade do jogo. "O ser do jogo é sempre resgate, pura realização, energeia, que traz seu telos em si mesmo. O mundo da obra de arte, no qual um jogo vem à fala, pleno dessa maneira, na unidade de seu decurso, é, de fato, um mundo totalmente transformado"202. A arte é precisamente a configuração daquilo que resulta desse sentido de transformação plena da realidade - "a subsunção dessa realidade em sua verdade [die Kunst als die Aufhebung dieser Wirklichkeit in die Wahrheit]",203.

Dando continuidade à explicitação desse conceito de transformação, chegamos ao segundo fio condutor da explicitação ontológica da experiência da arte. Enquanto jogo, o

\footnotetext{
${ }^{199}$ H.-G. GADAMER, WM, I, p. 116.

${ }^{200}$ Nesta passagem, Gadamer refere-se a Platão como crítico da arte, quando, em seu diálogo Filebo, compara a comédia e a tragédia da vida com aquelas apresentadas no palco. Ao perceber o real sentido do jogo (espetáculo) apresentado diante do espectador, o que aí se manifesta, tanto na comédia quanto na tragédia - é desnecessário diferenciá-las -, é o que se chama de "alegria do conhecimento" (Cf. H.-G. GADAMER, WM, I, p. 117).

${ }^{201}$ F. DASTUR, Phénoménologie et esthétique, p. 50.

${ }^{202}$ Id., ibid., p. 118.

${ }^{203}$ Id., ibid.
} 
modo de ser da arte define-se pela sua apresentação (Darstellung), cuja unidade e configuração dirige-se a nós repleta de sentido. Além de um movimento lúdico, o acontecimento da arte (Kunstgeschehen) é transformação em configuração dotada de plenitude ontológica. Em seu caráter declarativo, a arte é, também, para nós uma experiência simbólica, cuja significação nós a desenvolveremos em seu caráter complementar à noção de jogo da arte, ou mesmo da arte como "Gebilde".

Antes de tudo, convém mencionar, símbolo (symbolon) é um termo grego cujo sentido original indica, entre amigos, familiares ou membros de uma comunidade afastados, um sinal de pertencimento e de que se reconhecem entre si. São "pedaços de recordação" que deixam sobressair como presente aquilo que, embora não pareça, sempre se mantém presente ${ }^{204}$. Afirmar o caráter simbólico significa para a hermenêutica filosófica não apenas recuperar o sentido originário desse termo, distinguindo-o de alegoria ${ }^{205}$, mas também ressaltar a obra de arte como experiência de sentido que nos remete a algo que muitas das vezes não é diretamente compreensível. Ao reconsiderar a obra de arte como "Gebilde”, Gadamer adverte quanto à qualidade de configuração que "está aí" como algo consolidado. Ela não pode ser interpretada como mero suporte de sentidos, como uma simples abertura de sentido (Offenlegung von Sinn). Bem mais que isso, o jogo da arte, enquanto um movimento lúdico de apresentação (Darstellung), constitui-se como "acúmulo de sentido" (Bergung von Sinn) ${ }^{206}$, "plenitude ontológica" (die Seinsfülle) que vem a nosso encontro sob a forma de verdade

${ }^{204}$ Em $A$ atualidade do belo, ao indagar sobre o que seja "símbolo", nos diz Gadamer: "Um anfitrião dá a seu hóspedes a chamada 'tessera hospitalis', ou seja, ele quebra um caco no meio, conserva uma metade e dá a outra ao hóspede a fim de que, quando daí a trinta ou cinqüenta anos um sucessor desse hóspede vier de novo à sua casa, um reconheça o outro pelo coincidir dos pedaços em um todo. Uma espécie de antigo passaporte: tal é o sentido originário de símbolo. Algo com o qual se reconhece um antigo conhecido" (H.-G. GADAMER, AkSch, p. 84).

${ }^{205}$ Em Verdade e método, na análise sobre os limites da arte vivencial, Gadamer dá ênfase ao fato de que a natureza da obra de arte corresponde a uma disposição de formas fixas de manifestar e dizer. Sob esse ponto de vista, ele desenvolve um breve histórico dos conceitos de "símbolo" e "alegoria". Seu propósito é afirmar que a contradição tão auto-evidente que subsiste entre ambos é conseqüência do desenvolvimento filosófico do século XIX e XX. Em sua origem, há um distanciamento entre ambos: a alegoria refere-se ao discurso, ao logos, ao deixar-se entender por outro mais compreensível, ao remeter-se a algo fora de si; enquanto o símbolo, este tem em sua presença o seu significado necessário. Ambos, entretanto, equivalem-se na medida em que são estrutura de representação. É apenas na época de Goethe e Schiller que se consolida uma nova abordagem do conceito de símbolo. Em Goethe (tal como está nas formulações de Farbenlehre), refere-se não só a um estado sentimental de revelar impressões sobre a realidade - experiência ou simbolismo da realidade, a variedade de cores -, como também ao universo da totalidade - "Tudo o que acontece é símbolo e, ao representar a si mesmo, inteiramente acena para o resto" (Carta a Schubart). Em Schiller, esse significado é deslocado para o âmbito estético. "De fato, na caracterização do conceito de 'símbolo', já em Goethe, o decisivo tom está em que é a própria idéia que se dá existência nisso [...] no conceito de símbolo encontra-se implícita a unidade interna entre símbolo e simbolizado" (id., WM, I, p. 83).

${ }^{206}$ Por meio da expressão "acúmulo de sentido" (Bergung von Sinn), Gadamer sustenta, antes de tudo, uma rejeição ao conceito idealista de sentido. Em sua leitura, a definição do belo artístico como aparência sensível da idéia não faz justiça à circunstância de que a obra nos fala como obra, e não como transmissora de uma verdade. 
(aletheia). Mediante a transformação, aquilo que é representado não se converte em outra coisa, senão em si mesmo, naquilo que é em realidade. Mas, se esse ser apenas se revelasse por meio da obra de arte, não o conheceríamos, não fosse a própria função ontológica da arte em sua capacidade de transformar em configuração (Gebilde) o verdadeiro ser. Assim, essa ação ontológica da arte nos permite também entender a anterioridade de um mundo que agora se mostra transformado e acrescido e que se apresenta a nós como sinal de reconhecimento.

A relação entre arte e verdade que aqui começa a articular-se tem como influência notória a filosofia de Heidegger, seja em sua reconsideração do conceito de verdade, seja naquilo que este desenvolve como o pôr-em-obra-da-verdade, em sua obra $A$ origem da obra de arte (Der Ursprung des Kunstwerks). Através desta torna-se clara a especificidade da verdade (aletheia) que nos fala, advinda da arte, "num duplo movimento de descobrir (Aufdecken), desocultar (Entbergen) e revelar (Offenlegen), por um lado, e ocultamento

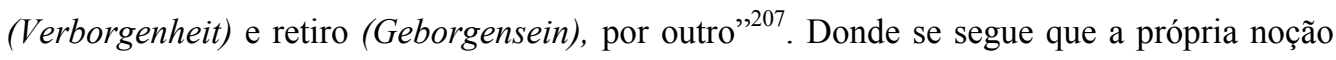
grega de desvelamento (expressa em alemão pelo termo Entborgenheit) constitui-se apenas como um lado da experiência fundamental do homem no mundo. Conforme ressalta Gadamer em $O$ que é a verdade? (Was ist die Wahrheit?), de 1957, a reflexão heideggeriana sobre a verdade, a partir da recuperação de seu sentido grego de "aletheia", tornou-se decisivamente promissora para o pensamento filosófico. A verdade é desvelamento, desocultação, mas na condição de ser "arrebatada da ocultação [Verborgenheit], do velamento [Verhohlenheit] $[\ldots]^{208}$. Ao abordar a questão da essência da verdade, entende Gadamer, Heidegger ultrapassa o horizonte subjetivo concernente à problemática do conhecimento, deslocando-a para o âmbito ontológico. Pensada a partir dos gregos, a verdade (aletheia) é a verdade dos entes e, nesse sentido, corresponde a sua desocultação (Unverborgenheit). O interessante, todavia, é perceber que o processo de desocultação da verdade advém de uma abertura inerente aos entes que Heidegger denomina "clareira", nossa via de acesso a eles, em seus diferentes modos. Sua revelação, entretanto, pressupõe seu próprio ocultar-se, constituindo-se um jogo em que a clareira, simultaneamente, é abertura e ocultação, dissimulação (Verstellen) revelação. Isso justificaria equívocos, erros e enganos diante de coisas e ações cometidas. Nesse sentido, diz Heidegger: "A ocultação pode ser um enganar-se ou apenas uma dissimulação. Nunca temos a certeza se é uma coisa ou outra. A ocultação oculta-se e dissimula-se a si mesma. Quer isso dizer: o lugar aberto no seio do ente, a clareira nunca é um palco rígido, com o pano sempre levantado e sobre o qual o jogo do ente representa-se. Antes

\footnotetext{
${ }^{207}$ H.-G. GADAMER, AkSch, in: GW, 8, p. 125.

${ }^{208}$ Id., WM, II, p. 46.
} 
pelo contrário, a clareira acontece apenas sob a forma dessa dupla reserva..."209 . A verdade, na sua essência, pertence a seu próprio negar-se, o que implica dizer que, esta não se mantendo, ela só pode ser representada considerando o seu contrário. Em sua relação com a arte, a verdade está em obra, acontece na obra; em seu tornar-se manifesto, os entes que a integram, em seu conflito recíproco - clareira e ocultação - alcançam a verdade, desocultam-se.

Partindo-se, no entanto, do pressuposto de que compreender o significado da fundamentação simbólica da arte significa um retorno a Heidegger como contraponto à noção de revelação de sentido proposta pela estética idealista, torna-se ainda necessário um esclarecimento sobre a questão da representação simbólica desenvolvida por Gadamer. O sentido atribuído ao simbólico não corresponde apenas a um remeter (werwiesen) a significações ou mesmo um signo recordativo. Representar (Repräsentieren) implica, no entanto e precisamente, "um tornar presente", "um fazer estar presente", porém não em seu caráter substitutivo, indireto, mas um estar-aí na representação (Dasein in Repräsentation). Representa enquanto "faz as vezes do outro" (vertritt). Um quadro que retrata uma personalidade pública, ao ser pendurado, ressalta Gadamer, retrata sempre um fragmento de sua presença. "A obra de arte não só se remete a algo, como também nela está propriamente aquilo a que se remete" ${ }^{, 210}$. Tal caráter representativo da presença constitui o que Gadamer denomina um "crescimento do ser" (Zuwachs an Sein); eis o que torna a obra de arte um acontecimento único.

Convém acrescentar ainda que, embora durante a abordagem da experiência artística enquanto movimento lúdico Gadamer utilize, sobretudo, a expressão Darstellung, Selbstdarstellung, aqui, em sua explicitação simbólica, a expressão usada é Repräsentation, cujo significado específico remete-nos àquele próprio do direito canônico e público: um estaraí pleno.

A experiência da arte é uma experiência de conhecimento, porém, num sentido bem específico de anamnesis. Conduz-nos a conhecer de novo o mundo em que vivíamos como se realmente fosse nossa primeira experiência dele; mas só que agora, distanciados do caráter funcional e prático da vida cotidiana, o vemos tal como ele é. Desse modo, Gadamer atribui à experiência da arte a possibilidade de revelar-se a verdadeira realidade, um acrésimo de ser (Zuwachs an Sein). É precisamente nesse sentido que os sapatos pintados por Van Gogh têm

\footnotetext{
${ }^{209}$ M. HEIDEGGER, A origem da obra de arte, p. 43.

${ }^{210}$ H.-G. GADAMER, AkSch., in: $G W, 8$, p. 126.
} 
esse a mais, esse acréscimo de ser, se comparados àqueles encontrados na aldeia; em sua representação eles revelam a essência destes últimos.

Para explicitar esse caráter distintivo da arte, em seu caráter ontológico de conhecimento e reconhecimento, Gadamer toma como recurso o conceito grego de "mimesis", em sua específica função cognitiva. O hermeneuta então reabilita uma compreensão sobre a arte, bastante antiga, que remonta a Platão. Imitar consiste, pois, em representar o que é conhecido - "é imitando que a criança começa a brincar, fazendo o que conhece e confirmando assim a si mesma” ${ }^{211}$. A arte é mimesis não pelo fato de simplesmente imitar, copiar o já conhecido, mas, sobretudo, por trazê-lo à representação, tornando-o presente. Que a representação só mantenha o representado, pois é só ele que ali deve ser reconhecido $^{212}$. Do ponto de vista da mimesis, o conhecimento constitui-se, pois, como reconhecimento (Wiedererkennung), fenômeno fundamental e imprescindível, no entender de Gadamer, para o esclarecimento do sentido do ser da representação.

Em sua configuração representativa, o que nos mobiliza diante da arte e aí nos permite uma demora (Verweilen) é, nesse sentido, nossa predisposição de nela reconhecermos algo. Contemplá-la significaria, desse modo, a permanência num reconhecimento. Reconhecimento não no sentido limitado de conhecer mais uma vez o que, outrora, já fora conhecido reconhecer o conhecido -, mas tomando-o, em sua essência, como uma espécie de "iluminação", por meio da qual se identifica $\operatorname{algo}^{213}$. Assim, o que a relação mimética implica não é somente que o representado esteja aí presente, mas, precisamente, que o conhecido seja trazido à representação - a sua vinda no aí (ins $D a$ ) -, manifestando-se em sua plenitude de sentido. Por isso não se trata de uma simples repetição de caráter demonstrativo, mas de conhecimento, extração (Hervorholung), pôr em relevo aquilo que advém do próprio espectador. É precisamente neste sentido que, para Heidegger, só no quadro os sapatos de Van Gogh, ou mesmo a pessoa representada, chegam a seu ser verdadeiro e reconhecível. É graças

${ }^{211}$ H.-G. GADAMER, WM, I, p. 119.

${ }^{212}$ Nesse sentido, como muito bem lembra Gadamer, Aristóteles também nos ensina que o imitar é não só inerente ao homem, como também um elemento diferencial de sua existência. Ao imitar, ele se compraz no imitado. "Sinal disso é o que acontece na experiência: nós contemplamos com prazer as imagens mais exatas daquelas mesmas coisas que olhamos com repugnância [...] Efetivamente tal é o motivo por que se deleitam perante as imagens: olhando-as, aprendem e discorrem sobre o que seja cada uma delas, [e dirão], por exemplo, "este é tal"” (ARISTÓTELES, Poética, 1448b).

${ }^{213}$ A análise do fenômeno do reconhecimento remete Gadamer a uma questão central do platonismo, presente na doutrina da anamnesis. Diz-nos então: "Juntamente com sua doutrina da 'anamnesis', Platão concebeu a idéia mítica da reminiscência como caminho de sua dialética, que procura nos logoi, isto é, na idealidade da linguagem, a verdade do ser. Na realidade, um tal idealismo da essência é posto no fenômeno do reconhecimento. O conhecido alcança seu verdadeiro ser, e mostra-se como o que ele é apenas por meio do reconhecimento. Enquanto reconhecido, é aquilo que se mantém firme em sua essência, liberto da causalidade de seus aspectos" (H.-G. GADAMER, WM, I, p. 119). 
à sua configuração que o ser obtém sua própria "valência ontológica". Mas na arte o que aparece transformado não é simplesmente um ser de caráter objetivo. A transformação também inclui os que nela participam. Transformamo-nos à medida que passamos a perceber diante de nossos olhos o ser transformado de nosso mundo que somos nós mesmos. Por isso é que a arte não só transforma enquanto movimento ontológico de representação; sua ação sempre altera aquele que a contempla e a quem ela se revela como acontecimento de verdade.

$\mathrm{Na}$ representação da arte é o próprio reconhecimento, isto é, o conhecimento da essência, que está em obra. A essa idéia de mimesis, todavia, o que se tornou evidente era, portanto, a função cognitiva da arte, cuja perda Gadamer associa ao advento do caráter subjetivo da consciência estética:

"Como representação, a imitação possui uma função cognitiva muito característica. Tal é
a razão por que o conceito de imitação pôde bastar à teoria da arte enquanto não se
discutia o significado cognitivo deste. Mas isso só se manteve enquanto se identificou o
conhecimento da verdade com o conhecimento da essência, pois a arte serve a esse tipo de
conhecimento de maneira convincente. Pelo contrário, para o nominalismo da ciência
moderna e seu conceito de realidade, do qual Kant extraiu as conseqüências agnósticas, o
conceito de mimesis perdeu o seu vínculo estético"214.

Diante do exposto acima, a explicitação lúdica e simbólica da experiência artística ratifica o questionamento do caráter subjetivo da experiência estética da arte, sobretudo quando se predispõe à análise do conceito de representação (Darstellung und Repräsentation), próprio do modo de ser da obra de arte. Representação, cuja significação conceitual é depreendida do conceito mesmo de jogo, do próprio movimento lúdico do jogar, do qual o espectador também é parte integrante. Tendo em vista essa elucidação, pode-se melhor entender a tese gadameriana de que "o ser da arte não pode ser determinado como objeto de uma consciência estática, porque, ao contrário, o comportamento estético é mais do que se sabe de si mesmo. É uma parte do processo do ser da representação e pertence ao jogo como jogo" 215 . Por conseguinte, torna-se inteiramente inadequada a idéia de uma diferenciação estética que põe e toma o objeto estético para si, desconsiderando as relações de circunstâncias em que a própria experiência verifica-se. Do ponto de vista de uma ilustração e melhor esclarecimento sobre essa questão, Gadamer refere-se ao espetáculo tanto teatral quanto poético e então nos diz: "A obra de arte não é simplesmente isolável da 'contingência' das condições de acesso sob as quais se mostra, e, onde esse isolamento acaba ocorrendo, o

\footnotetext{
${ }^{214}$ Id., ibid., p. 120.

${ }^{215}$ Id., ibid., p. 121-2.
} 
resultado é uma abstração, que conduz o ser próprio da obra. O espetáculo só acontece onde está sendo representado, e a música em plenitude deve soar"216.

Em outras palavras, isolada das condições de acesso sob as quais ela se mostra, a obra de arte resulta em abstração empobrecida; isto porque dessa forma esta nos priva do mundo a partir do qual se apresenta. À abstração da diferenciação estética, elemento constitutivo da consciência estética, opõe-se a concepção de transformação em configuração (Gebilde), ou seja, ao todo significante do jogo que, enquanto ser jogado, assume sua configuração e alcança sua plenitude na diversidade de seu poder ser representado, mediante seu sentido. Essa forma de oposição, Gadamer denomina "não diferenciação"217 (ästhetische Nichtunterscheidung). Não mais se constituindo como objeto de uma consciência estética, o ser da obra de arte apenas pode ser definido tendo em vista o processo ontológico da representação, e não de modo puramente estético. É somente no sentido de atividade lúdica e movimento de representação que a obra de arte atinge a plenitude de seu ser. Ela não constitui um "em si", um puramente estético, que tem necessidade, para ser encontrado, de uma mediação acidental para ele, mas, bem ao contrário, é só em uma mediação (Vermittlung) profunda que a arte adquire seu ser verdadeiro.

Como advertência, porém, no sentido de uma melhor compreensão sobre essa questão, diz-nos Grondin: "Quando Gadamer fala aqui de uma 'não diferenciação estética', então sabe perfeitamente que a não diferenciação inclui em si conjuntamente à distinção, melhor dizendo: o caráter distinto da arte" ${ }^{218}$. A arte, enquanto um acontecimento único e essencial, convida-nos sempre a permanecermos nela, e, portanto, não deve ser diferenciada do mundo. Numa ponderação eminentemente subjetiva da consciência estética, realça-se unicamente essa diferenciação, em detrimento de sua relação necessária com o mundo. Ao nos proporcionar um crescimento do ser (Zuwachs an Sein), a obra de arte revela o mundo em sua específica pretensão de verdade.

Aquilo que é imitado, ou até representado, uma vez reconhecido pelo espectador, é exatamente o significado mesmo da representação; o que se diferencia é apenas a formulação ou ainda a composição poética, essas de natureza inteiramente secundárias. Aquilo que é reconhecido corresponde às formulações e à própria ação do poeta, do criador. Na verdade,

\footnotetext{
${ }^{216}$ H.-G. GADAMER, WM, I, p. 121.

${ }^{217} \mathrm{Em}$ A atualidade do belo Gadamer apresenta a noção de "indiferenciação estética" a partir da necessidade de ser desenvolvida uma crítica à própria noção de percepção. "Perceber não é colecionar várias e diversas impressões sensoriais, mas quer dizer, como a palavra alemã mesma diz, Wahrnehmen, tomar algo como verdadeiro" (id., AkSch, in: GW, 8, p. 119).

${ }^{218}$ J. GRONDIN, Introducción a Gadamer, p. 71.
} 
como diz Gadamer, o que a obra poética exige é que a representação mímica da encenação conduza todo esse movimento a ser-aí (Da-sein). Portanto, não se trata, por exemplo, de prender-se ao desempenho de um ator como tal, o que já seria uma diferenciação estética da própria obra no tocante a sua representação. Quanto à variedade das execuções de uma obra, esta não pode ser considerada como uma disposição meramente subjetiva de concepções, mas como reais possibilidades de ser inerentes à obra de arte, cuja auto-interpretação dá-se na multiplicidade de seus aspectos. É a própria obra de arte, por ela mesma, que tem a exigência de exatidão de sua própria representação. Por isso, a idéia de representação não comporta o sentido de única representação, mantendo-se, dessa forma, exata e fiel a um ponto de vista histórico. A interpretação, por mais que se manifeste como um fazer de acordo com o anterior (Nachschlafen), corresponde, mais significativamente, à figuração de uma obra criada que, havendo sentido nela, é trazida à representação ${ }^{219}$. Nas artes reprodutivas, como, por exemplo, a música, ressalta Gadamer, a obra está necessariamente vinculada a seu intérprete, a sua forma peculiar, que o desobriga de uma simples "imitação" com relação ao modelo ou a um padrão de representação correta.

À diferenciação estética da obra com relação a sua intermediação ou execução, Gadamer contrapõe a "não diferenciação estética" entre a intermediação e a obra; eis o que perfaz a verdadeira experiência da obra.

Assim, por meio dos conceitos de jogo (Spiel), transformação em configuração (Gebilde) e símbolo inerentes à experiência da arte, Gadamer intenta mostrar que o fenômeno da representação, seja a execução da poesia, ou de uma música é qualquer coisa de essencial, e não de acidental. Enquanto jogo, o ser da obra de arte é experiência de abertura e, ao mesmo tempo, unidade de sua própria configuração. Enquanto configuração, está sempre vinculado a possibilidades de representação tendo em vista o caráter simbólico do reconhecimento. Por isso, o jogo da arte corresponde a esse movimento lúdico que envolve a obra - Gebilde - em sua totalidade, ou seja, a obra em sua presença objetiva e o horizonte de sua assimilação.

\footnotetext{
${ }^{219}$ Gadamer adverte-nos de que de fato as representações artísticas subordinam-se a uma espécie de padrão de representação correta. Isso significa que o objeto estético é constituído em virtude de sua concretização e constituição, e não pelo caráter de vivências das recepções estéticas. Para Gadamer, o artista reprodutivo ao aproximar-se de uma obra também se aproxima de seus modelos, o que não se constitui como uma cega imitação. "A tradição que é criada por um grande ator, regente ou músico, na medida em que seu modelo continua atuante, não é necessariamente obstáculo para a livre criação, mas se terá fundido de tal maneira com a obra, que o confronto com esse modelo não evoca menos a reformulação criativa posterior de todo artista, do que o confronto com a própria obra. As artes reprodutivas possuem [...] esse algo especial [...] algo que libera expressamente as obras, com as quais ela tem a ver, para tais reformulações, e com isso mantém visivelmente aberta a identidade e a continuidade da obra de arte voltada para o futuro" (H.-G. GADAMER, WM, I, p. 124).
} 
A partir dessas considerações, a poesia, a música, o quadro, eles nunca existem no caráter objetivo e absoluto. A poesia é sempre poesia que se recita e se entende, de modo que sua palavra tem sempre a pretensão de uma resposta, de um diálogo. E, assim como ela, também o quadro, embora não pronuncie, necessariamente, a linguagem das palavras, pretende ser interpelado, contemplado. Da mesma forma, escutar uma música é também fazer sua melodia vibrar internamente, mesmo que não haja um acompanhamento desse ritmo musical, seja com os dedos ou com os pés ${ }^{220}$. Esse jogar junto da obra de arte é pura interpelação que nos transforma e nos põe diante de nós mesmos.

Mas o caráter ontológico de seu movimento de re-presentação (Darstellung) também permite que, enquanto experiência, as obras ultrapassem seu lugar de origem e, atravessando o tempo, instalem sua contemporaneidade em todo e qualquer presente. A experiência ontológico-hermenêutica da arte remete-nos, ainda, à tarefa de sua própria temporalidade histórica.

\footnotetext{
${ }^{220}$ Cf. H.-G. GADAMER, Musik und Zeit, in: $G W, 8$.
} 


\section{ARTE E HISTÓRIA: UMA REFLEXÃO HERMENÊUTICA}

Tendo o projeto de elaboração dos fundamentos filosóficos da hermenêutica como ponto de partida a retomada da questão da verdade da arte sob a forma de sua explicitação ontológica, a abordagem da problemática concernente à compreensão das ciências humanas (Geisteswissenschaften) apresenta, como conseqüência, segundo Gadamer, um horizonte duplamente crítico. Então afirma: "Também para nós a questão da verdade da arte obrigou a uma crítica da consciência tanto estética quanto histórica, ao mesmo tempo em que indagamos pela verdade que se manifesta na arte e história"221. Assim, se, por um lado, temos a questão da verdade (aletheia) estendida a uma interrogação crítica acerca da história, por outro, verificamos que uma análise sobre o fenômeno da arte, no rigor de uma experiência hermenêutica da verdade, inclui, necessariamente, a especificidade de que não pode prescindir do caráter de sua temporalidade histórica. Na qualidade de seu modo de ser, os produtos artísticos sempre constituíram manifestações do espírito cultural de um povo. Independentemente de sua função sociopolítica e religiosa, os produtos artísticos, essencialmente, determinam-se como representações histórico-temporais, já que testemunho e memória de uma tradição que avança no tempo e conquista uma atualidade.

Dentro do contexto de análise hermenêutica no qual estamos aqui inseridos, a afirmação do caráter histórico da experiência da arte pode ser duplamente justificada. A princípio, retomando-se o que fora anunciado desde a apresentação da problemática central a partir da qual se evidencia a relação estética e hermenêutica. Seu horizonte analítico, além de pretender uma investigação ontológica sobre o modo de ser da arte, remete-nos também a uma análise de sua presença declarativa. Sua particular expressão de verdade (Ausdruck einer Wahrheit) constitui uma experiência e declaração de sentido cuja atualidade ultrapassa a limitação histórica (geschichtliche Beschränktheit) e o próprio tempo. Por outro lado, do ponto de vista de sua caracterização conceitual, a hermenêutica filosófica é também histórica; seja no sentido de submeter seus objetos de análise à condição de experiência hermenêutica; seja, até mesmo, pelo procedimento investigativo acerca do desenvolvimento do método hermenêutico na transformação de sua própria essência: de doutrina da arte da compreensão e interpretação, em seus caminhos teológico e filológico, à sua constituição como "órganon histórico".

Assim, a compreensão hermenêutica da arte põe-nos diante da seguinte tarefa de pensamento: identificar como se articula a relação entre arte e história, ou mesmo como se

$\overline{{ }^{221} \text { H.-G. GADAMER, WM, I, p. } 269 .}$ 
desenvolve a particularidade de uma reflexão histórica sobre a arte tendo em vista os fundamentos da hermenêutica filosófica de Gadamer.

Em benefício de sua autonomia, a própria constituição da hermenêutica, no processo de revisar críticamente sua tarefa, desenvolveu uma ampla e intensa discussão críticometodológica com as ciências humanas, e, de modo bem insistente, com as diferenciações do historicismo. Gadamer está convencido de que, ao longo do século XIX, o desenvolvimento da hermenêutica, centrando-se no foco da compreensão, aliou-se excessivamente a premissas metodológicas . Daí a necessidade de rever os equívocos inerentes ao desenvolvimento do problema hermenêutico tendo em vista sua superação. Esta revisão crítica tem um sentido de confronto direto com a hermenêutica do século XIX, sobretudo a partir de Schleiermacher e Dilthey $^{222}$. Embora bastante empenhados em sua intenções, esses dois pensadores referenciais da hermenêutica moderna não resistem ao pensamento em parte metódico, em parte “estético", manifestando dessa forma a unilateralidade de suas apresentações. Neste momento, não temos, todavia, como objetivo problematizar a questão da história enquanto experiência hermenêutica propriamente dita na amplitude de sua análise histórico-conceitual gadameriana. Mesmo reconhecendo sua importância não pretendemos desenvolver uma exposição ampliada sobre as aporias identificadas por Gadamer nos pensamento de Schleiermacher ${ }^{223}$ e Dilthey, no tocante à hermenêutica.

Trata-se apenas de identificar o que justifica uma ponderação histórica sobre o fenômeno da arte enquanto elemento fundamental de sua análise hermenêutica como

${ }^{222} \mathrm{O}$ confronto de Gadamer com a hermenêutica romântica, da qual Gadamer mostra-se como um grande herdeiro, apresenta tons bastante polêmicos. Embora Gadamer identifique uma unilateralidade nas reflexões de Schleiermacher e Dilthey, estas anteciparam indiscutível e consideravelmente suas idéias hermenêuticas. O que justificaria esse revisionamento de Gadamer é seu próprio empenho crítico contra os argumentos de uma hermenêutica puramente metódica e estética. Por outro lado, como afirma Grondin, é importante atentar para o efeito dessa crítica desenvolvida por Gadamer a esses pensadores da hermenêutica: "A literatura revisionista de Schleiermacher e Dilthey (e não gostarão de ouvir) esquece também que, sem a destruição feita por Gadamer, provavelmente, hoje se falaria muito pouco sobre a hermenêutica de Schleiermacher e Dilthey. Com efeito, embora tenham se ocupado durante bastante tempo com esta, nem Schleiermacher nem Dilthey apresentaram ou publicaram uma concepção finalizada, pelo menos sob medida, da hermenêutica. Schleiermacher teria seguido provavelmente sendo para nós [...] o autor de Reden über die Religion [Discursos sobre a religião, 1797] e de uma Glaubenslehre [Doutrina sobre a religião, 1821-2], quer dizer, um grande teólogo protestante [...] Dilthey seguiria sendo um impressionante historiador da filosofia [...] e um grande metodólogo das ciências humanas como o autor de Einleitung in die Geisteswissenschaften [Introdução às ciências humanas, 1883] [...] Embora tendo influenciado na Escola Histórica, a notoriedade que Gadamer proporciona a sua hermenêutca é o que permitiu que se retornasse aos enfoques fragmentários da hermenêutica de Schleiermacher e Dilthey. Outro caso em que a destruição serviu para o redescobrimento" (Cf. J. GRONDIN, Introducción a Gadamer, p. 97).

${ }^{223}$ Gadamer está bastante atento ao fato de que, enquanto as hermenêuticas tradicionais definiram-se pela especificidade de seu objeto, a hermenêutica universal de Schleiermacher volta-se para o procedimento do compreender, comum a todas elas. Mediante essa nova orientação, a unidade da hermenêutica não mais se fundamenta em sua referência ao objeto, mas na unidade de um procedimento. A crítica que Gadamer dirige a essa hermenêutica romântica baseia-se no fato de que esta está dirigida ao compreender restrito a uma expressão como tal, e não, essencialmente, à coisa, à verdade. É esse interesse pelo entender que também caracteriza a hermenêutica como "doutrina da arte de compreender". 
experiência de verdade. Desse modo podemos indagar: qual a especificidade do significado conceitual da história, desenvolvido pela hermenêutica filosófica de Gadamer, que, por sua vez, legitima a afirmação da arte como "presença declarativa atualizada"?

Desse modo, faz-se necessário, num primeiro momento, determo-nos na significação daquilo que Gadamer entende por princípio da "história dos efeitos" (Wirkungsgeschichte) ${ }^{224}$, horizonte fundamental para toda e qualquer compreensão hermenêutica.

\subsection{A hermenêutica sob a vigilância da História}

Aquilo que Gadamer denomina, sistematicamente, "hermenêutica científico-espiritual" (geisteswissenschaftliche Hermeneutik), ele desenvolve na segunda parte de Verdade e método sob o título "A extensão da questão da verdade à compreensão das ciências do espírito". Em sua pretensão, trata-se de reconquistar a especificidade da hermenêutica das ciências humanas, examinando, inicialmente, a história da hermenêutica e a transformação de sua essência na idade moderna ${ }^{225} \mathrm{e}$, posteriormente, as aporias do historicismo. O deslocamento de sua tarefa, de caráter dogmático, à função essencialmente histórica é o ponto de sustentação baseado no qual o fenômeno da compreensão deve, necessariamente, voltar-se à consciência histórica.

De acordo com a Escola Histórica ${ }^{226}$, seu propósito hermenêutico busca compreender a história universal no conjunto de seus nexos e relações, pois só assim se faz possível uma

\footnotetext{
${ }^{224}$ Sobre a tradução do termo Wirkungsgeschichte, optamos por "história dos efeitos", embora seja comum encontrarmos "história efetual", "história efetiva", "princípio de produtividade histórica", ou até mesmo "história das influências e recepção". Em alemão, o termo Wirkung - efeito - resulta de wirken, que, por sua vez, indica ação, atuação, um fazer efeito. Daí que Wirkungsgeschichte nos remete ao sentido de uma história dos efeitos, das conseqüências, dos resultados.

${ }^{225}$ Do ponto de vista das preliminares históricas sobre o questionamento da hermenêutica tradicional e sua aplicação à historiografia, Gadamer lembra-nos que, se, tanto no caminho teológico quanto no filológico, o propósito era identificar o sentido original dos textos, a partir da Reforma luterana tal procedimento assume uma modificação, um "impulso reformador". Compreender a Sagrada Escritura requer somente o sentido unívoco de sua literalidade, de modo que é seu contexto de conjunto que orienta a compreensão dos aspectos individuais. $\mathrm{O}$ que aí está pressuposto é o princípio da relação circular do todo com as partes, e vice-versa, já desenvolvido pela retórica clássica. O fundamento de compreensão da Bíblia torna-se dogmático, pois sua interpretação limita-se à pressuposição de que a Sagrada Escritura é uma unidade. Retomando os estudos de Dilthey sobre a hermenêutica, para Gadamer, é só no século XVIII, liberando-se de seus "enquadramentos dogmáticos", que a hermenêutica conduz-se ao caráter universal de sua significação histórica. Se a hermenêutica busca a compreensão, esta por sua vez, pressupõe uma restauração da realidade histórica e do contexto da vida e, por conseguinte, um direcionamento à consciência histórica. A interpretação tem que render-se, a partir de então, também à fontes históricas. Da dissolução de sua tarefa dogmática, cujo foco era a correta proclamação do evangelho, segue-se o alcance da verdadeira essência da hermenêutica - a função de um "organon histórico".

${ }^{226}$ A escola histórica não é estritamente uma escola filosófica, já que a integravam filólogos como August Boeck (1785-1867), como também historiadores como Leopold von Ranke (1795-1886) e Gustav Droysen (1808-84). Tendo em vista uma desconfiança para com as construções filosóficas, refletiram e apresentaram fundamentos metodológicos sobre a disciplina da história. $\mathrm{O}$ alvo de suas considerações críticas era a filosofia da história
} 
concepção histórica do mundo. Desse modo, o problema que daí decorre é que esse reconhecimento da historicidade universal do ser humano resulte na pretensão de um saber absoluto da história.

Como grande expoente do historicismo, Dilthey eleva a realidade do mundo histórico à condição de um texto a ser decifrado. Nesse sentido, pensa Gadamer, sua reflexão é bemsucedida, pois assim parece dar conta da tarefa de justificar epistemologicamente as ciências humanas. No mundo histórico nada é compreensível senão por sua semelhança a um texto que, formado por palavras, tem um significado a ser compreendido e decifrado. Os acontecimentos históricos não podem ser deduzidos de um sistema metafísico, mas a partir de si mesmos, de seu próprio contexto histórico. Dilthey compreende o triunfo da hermenêutica com base na superação histórica da metafísica e da conseqüente descoberta do espírito histórico em tudo; eis o que possibilitaria uma interpretação espiritual e científica e uma verdadeira compreensão da vida. Conhecemos historicamente devido à radicalidade de sermos históricos. O problema situa-se em como conciliar esse condicionamento histórico de nossa consciência com a concepção de um saber absoluto da história. Na medida em que o historicismo não consegue abandonar toda forma de idealismo, a tendência dos fatos históricos é permanecerem nebulosos, uma vez incorporados ao marco maior da história universal. A questão que então se põe é: como legitimar o conhecimento historicamente condicionado com a sustentação epistemológica e objetiva da ciência? A problemática de Dilthey também se concentra no desafio da consciência histórica, tendo em vista o giro epistemológico empreendido por ele. Uma vez que toda e qualquer manifestação do espírito só pode ser entendida mediante seu caráter histórico, como conferir à história a garantia de um conhecimento universal?

Uma hermenêutica autenticamente histórica, ressalta Gadamer, deve ter a clareza, sobretudo, de que " o conhecimento histórico não pode ser descrito segundo o modelo de um conhecimento objetivista, já que ele mesmo é um processo que tem todas as características de um acontecimento histórico"227.

Conforme sumariamente mostramos, segundo Gadamer, o projeto de Dilthey de conciliar suas reflexões epistemológicas, no intuito de fundamentar as ciências humanas, com sua compreensão acerca da historicidade, a partir da filosofia da vida, resulta num insucesso.

idealista escrita por Hegel, em oposição à qual defendiam um caráter científico dos estudos e pesquisas históricos. Para eles, a referência idealista de uma reflexão sobre a história é inadequada para pensar, devidamente, a singularidade e a contingência dos fatos históricos. Trata-se de uma crítica em favor da facticidade histórica e que sob diferentes acepções foi formulada contra Hegel.

${ }^{227}$ H.-G. GADAMER, O problema da consciência histórica, p. 57. 
De qualquer forma, além de uma perspectiva genética que envolve sua significação para a história da hermenêutica, a contribuição de Dilthey em seu confronto com Gadamer foi decisiva, já que, nesse confronto, evidencia-se a transição de uma hermenêutica histórica para uma abertura fenomenológica, ou seja, dá-se aí a superação do questionamento epistemológico pela investigação fenomenológica. É o tema da "intencionalidade", presente na "fenomenologia" de Husserl, que surge como ruptura crítica à concepção metodológicoobjetivista do pensar anterior ${ }^{228}$. Da mesma forma que para Dilthey torna-se inadmissível um retorno ao sujeito epistemológico - proposto pelo neokantismo -, retrocedendo em contrapartida à unidade da vida, assim também a investigação fenomenológica de Husserl tem como seu verdadeiro propósito não mais falar de consciência, no caráter de sua subjetividade, mas da vida. Trata-se de uma intencionalidade anônima, diz Gadamer, por meio da qual instaura-se o que ele denomina "mundo da vida" (Lebenswelt); mundo no qual estamos inseridos pela nossa condição natural e que, por isso, representa o "solo prévio de toda experiência" ${ }^{229}$. A reconsideração husserliana do "mundo da vida" como fundamento originário de toda intencionalidade e pressuposto a toda ciência constitui-se uma oposição à concepção de objetivismo do mundo representado pelas ciências. Enquanto um conceito fundamentalmente histórico, a referida expressão não corresponde àquilo que o mundo é, mas à totalidade daquilo que estamos vivendo, na qualidade de seres históricos que somos.

O giro empreendido pela visão fenomenológica assume aqui uma grande importância na medida em que promove um retorno às coisas mesmas como forma de superação do paradigma metodológico e a teoria da ciência sustentada pelo neokantismo. A partir da noção de intencionalidade da consciência, as coisas mesmas nunca são independentes da consciência. Só se pode falar em objetividade, ou mesmo em abertura do objeto, considerando-se o significado constitutivo da intencionalidade da consciência. Ainda que assim seja, para Gadamer, Husserl, ao falar de uma constituição do "mundo da vida" que deveria reduzir-se a um eu originário (Ur-Ich), não consegue seguir adiante; e nesse sentido estaria ainda ligado aos esquemas do pensamento idealista e epistemológico.

É, todavia, apenas a partir do projeto heideggeriano de uma "fenomenologia hermenêutica", com base na significação da "hermenêutica da facticidade", que será neutralizado esse empenho obsessivamente epistemológico pretendido pelo historicismo. A "hermenêutica da facticidade" mediante a radicalização da historicidade (Geschichtlichkeit)

\footnotetext{
${ }^{228}$ Como bem afirma Husserl: "A fenomenologia intencional, pela primeira vez, fez do espírito enquanto espírito um campo de experiência sistemática e uma ciência, dando, com isso, uma reviravolta total à tarefa do conhecimento" (citado em id., WM, I, p. 370).

${ }^{229}$ H.-G. GADAMER, WM, I, p. 375.
} 
assume a orientação de descobrir a pressuposição metafísica das idéias de fundamentação e subjetividade

Do ponto de vista sistemático da obra Verdade e método, vale ressaltar que aquilo que Gadamer entende como "os traços fundamentais de uma teoria da experiência hermenêutica" 230 tem como ponto de partida a "elevação da historicidade da compreensão como princípio hermenêutico" ${ }^{\text {231 }}$. Isso significa que o desenvolvimento de uma reflexão hermenêutica, ao submeter seu objeto de análise à condição de experiência, também o conduz, necessariamente, sob um fundamento particular da historicidade, cuja significação advém da própria análise heideggeriana sobre o compreender ${ }^{232}$.

Sob a perspectiva de sua análise existencial, a compreensão, de acordo com a estrutura do "círculo hermenêutico" heideggeriano, tem como princípio nossa própria historicidade; eis o que a converte em um princípio hermenêutico. Por isso, toda e qualquer reflexão hermenêutica, ao submeter à compreensão um fenômeno hermenêutico, necessariamente, articula-o também ao caráter de sua historicidade. Mas, se isso se estabelece como um princípio da teoria hermenêutica gadameriana, sua elucidação por sua vez pressupõe a estrutura circular da compreensão formulada por Heidegger a partir da temporalidade do Dasein.

Em sua análise sobre o Dasein, Ser e tempo o examina enquanto estrutura fundamental do ser-no-mundo. Enquanto tal, ele mantém-se em uma totalidade aberta de significação buscando compreender-se em seu caráter intramundano. Como ser no mundo, ele é, antes de tudo, abertura enquanto transitividade de si mesmo; é o vir ao encontro de si mesmo (sich befinden) como disposição (Befindlichkeit). Ao fazer-se experiência de si mesmo, abrindo-se a si próprio, a estrutura de abertura do Dasein remete-nos a seu segundo existencial: a compreensão. Sendo em função de si, ele configura-se como mundo, mundo projetado que se lança como seu próprio mundo. Por isso, a expressão ser-no-mundo implica que, na condição de estar aberto para si, conhece-se como projeto, como ser-no-mundo. É pois nesse sentido

\footnotetext{
${ }^{230}$ Id., ibid., p. 270.

${ }^{231}$ Id., ibid.

${ }^{232} \mathrm{O}$ que se denomina "virada ontológica" da hermenêutica filosófica teve seu início nos anos 20 do século XX com o filósofo Heidegger, considerando-se sua reflexão sobre o círculo hermenêutico enquanto núcleo central para o entendimento da estrutura da compreensão e de suas condições de possibilidades. Aqui está precisamente a fronteira entre os dois campos da hermenêutica contemporânea: a hermenêutica epistemológica de Schleiermacher e Dilthey e a hermenêutica ontológica em que se situam Heidegger e Gadamer. Ainda sobre a importância desse caráter de inversão que a filosofia de Heidegger representa no cenário da hermenêutica, diz Gadamer: "[...] o projeto heideggeriano de uma ontologia fundamental tinha como pano de fundo o problema da história. Em breve, todavia, se perceberia que, nem a solução do problema do historicismo, nem uma fundamentação originária das ciências, incluída a fundamentação ultra-radical de Husserl, constituíram o sentido dessa ontologia fundamental; é a idéia mesma de fundamentação que experimenta agora um giro total" (H.-G. GADAMER, $W M$, I, p. 261).
} 
que o compreender, não se constituindo uma mera capacidade teórica do Dasein, equivale à estrutura de seu ser, a uma abertura de si mesmo como possibilidade. O Dasein não apenas se compreende enquanto ente, como também é determinado em seu ser pela possibilidade, pela capacidade de compreender-se a partir de seu mundo. Desse modo, ao dizer, por exemplo, "eu mesmo me compreendo" quero dizer que me compreendo porque aí sou para mim, aí me dôo a mim mesmo como tal, seja em qualquer atividade na qual me reconheça identificado. Embora a formulação heideggeriana do círculo hermenêutico comece a ser anunciada desde o $\S 25$ de Ser e tempo, quando então Heidegger toma como ponto de partida a questão existencial sobre o "quem" do Dasein ${ }^{233}$, é apenas no $§ 32$ que o círculo é efetivamente tematizado. Aí se articulam em movimento circular as três compreensões do Dasein: o serpróprio, o ser-com e o ser-aí. E, na medida em que envolve a estrutura triádica dessa pergunta pelo "quem", essa circularidade também nos remete à pergunta originária sobre o sentido do $\operatorname{ser}^{234}$ no tempo. Tempo aqui se refere à própria estrutura temporal do Dasein, cuja constituição concreta garante a unidade e a possibilidade da compreensão e de seus demais existenciais.

O "círculo hermenêutico" refere-se à própria investigação sobre como a interpretação compreensiva realiza-se; como ela funda-se existencialmente na compreensão, elaborando suas possibilidades projetadas. Não há interpretação sem antecipação compreensiva. Sobre essa circularidade, Gadamer remete-nos à seguinte passagem escrita por Heidegger:

"Nele se encontra uma possibilidade positiva do conhecimento mais originário, que, evidentemente, só será compreendido de modo adequado quando a interpretação compreendeu que sua tarefa primeira, constante e última permanece sendo a de evitar que as ocorrências e os conceitos populares de alguma forma se imponham enquanto o ter, o ver e o conceber prévios [Vorhabe, Vorsicht, Vorbegriff] [...],",235.

Para Gadamer, esse círculo, cujo sentido ontológico é positivo, tem a evidência de sua descrição expressa em todo e qualquer intérprete consciente daquilo que faz. Nesse sentido, deve resistir àquilo que se apresenta e se impõe como "feliz idéia" ou mesmo enquanto concepções imediatistas do pensar; em lugar disto deve dirigir-se às coisas mesmas, deixar-se determinar pela sua evidência própria. É como alguém que, vislumbrando a interpretação de

\footnotetext{
${ }^{233}$ Trata-se aqui da constituição ontológica do Dasein em duas determinações fundamentais. A explicitação dessa pergunta implica os três modos de compreensão do Dasein, por sua vez, intimamente imbricados: o Dasein em seu caráter próprio, seu ser próprio, como si-mesmo; como outro, ser-com; e, por último, o Dasein como "pre", ou mesmo "aí" (Cf. M. HEIDEGGER, Sein und Zeit, §§ 25, 26 e 27).

${ }^{234}$ Convém ter claro que em Ser e tempo a analítica do Dasein constitui-se como percurso aberto pela formulação da questão fundamental e originária proposta por Heidegger, qual a própria interrogação sobre o sentido do ser.

${ }^{235}$ Id., El ser y el tiempo, $§ 32$.
} 
um texto mediante sua leitura, deve manter-se atento ou mesmo submetido a todos os desvios. Compreendê-lo é como um projetar-se a partir de expectativas e na perspectiva de um sentido tão logo apareça; é a predisposição a elaborar esse projeto prévio, possibilitando constantes revisões mediante as quais se prolonga e avança seu próprio sentido. Essa concepção de projeto (Entwerfen) ou mesmo o estado de ser lançado (Geworfenheit) do Dasein constitui o fundamento e o ponto de partida de uma hermenêutica da facticidade. O processo de rever um projeto, refazendo-o ou mesmo antecipando-o como um novo projeto de sentido é, precisamente, o que define o movimento de sentido do compreender ou interpretar. Como anteriormente enfatizamos, compreender corresponde, radicalmente, à tarefa constante de elaborar projetos, antecipações sobre as coisas que devem ser nelas posteriormente confirmadas $^{236}$. O que qualifica essa tarefa como constante é o horizonte de possibilidade da verdadeira compreensão, ou seja, a elaboração de opiniões prévias não arbitrárias a serem examinadas em sua legitimação e validade. Tais opiniões prévias constituem a précompreensão.

Diante da reflexão heideggeriana sobre a pré-compreensão, ressalta Gadamer: "Somente um tal reconhecimento do caráter essencialmente preconceituoso de toda compreensão leva o

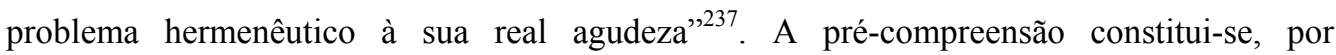
conseguinte, como a primeira das condições hermenêuticas. A circularidade da compreensão expressa, de fato, a circunstância de que toda interpretação deixa-se guiar pelos pressupostos do compreender, seja enquanto propósitos, previsão ou mesmo antecipação.

Entretanto, afirma Gadamer, existe um padrão crítico, constitutivo da tarefa hermenêutica. Trata-se de um questionamento inerente a sua tarefa, cuja advertência assim nos diz:

\footnotetext{
“Aquele que quer compreender não pode se entregar, já desde o início, à casualidade de suas opiniões prévias e ignorar o mais obstinada e conseqüentemente possível a opinião do texto [...] Quem quer compreender um texto deve deixar que ele diga alguma coisa por si [...] uma consciência hermeneuticamente formada tem que se mostrar receptiva, desde o princípio, para a alteridade do texto" ${ }^{238}$.
}

Em outras palavras, na medida em que viabilizamos uma abertura à alteridade para que o texto nos fale possibilitamos o confronto de sua verdade com o conjunto prévio de nossas

\footnotetext{
236 "Heidegger havia concedido um giro marcadamente ontológico, e não epistemológico: como o Dasein é uma essência de preocupação e se preocupa, primariamente, com seu futuro, compreende-se a si mesmo partindo de antecipações mais ou menos expressas. Com seus projetos de sentido intenta, por assim dizer, prevenir-se dos golpes, sabendo-se que a consciência os tem preparado, incessantemente, até o último e inevitável golpe da morte que todo empenho da metafísica tenta contornar" (J. GRONDIN, Von Heidegger zu Gadamer, p. 95).

${ }^{237}$ H.-G. GADAMER, WM, I, p. 274.

${ }^{238}$ Id., ibid., p. 273-4.
} 
opiniões. Por isso, o movimento metódico do compreender, primordialmente, deve assegurar uma consciência de controle sobre suas antecipações, vislumbrando, dessa forma uma compreensão a partir das coisas mesmas. Por isso também é que o conceito de interpretação hermenêutica constitui-se como um conceito interpretativo autocrítico, uma vez que preocupado com a demonstração das coisas mesmas.

Tendo como pressuposto que, a partir das reflexões de Heidegger, a hermenêutica filosófica de Gadamer ratifica enquanto fundamental o reconhecimento dos preconceitos como condição da compreensão, uma breve consideração histórica desenvolvida por Gadamer mostra que este conceito revestiu-se de um matiz bem diferente e negativo. Em alemão o termo correspondente é Vorurteil, cuja significação indica a formação anterior de um juízo (Urteil) acerca da determinação de algo, e não necessariamente um juízo falso sobre alguma determinação. Para o hermeneuta esse termo sofreu um significativo descrédito na Aufklärung ${ }^{239}$ alemã, assumindo o caráter de juízo destituído de fundamentação e carente de certeza. Não resistindo ao critério da dúvida metódica cartesiana, assimilado pela ciência moderna, os preconceitos tornam-se, conseqüentemente excluídos em sua pretensão de conhecimento científico. Essa posição de afastar os preconceitos com vistas a possibilitar algo mais próximo à objetividade das ciências foi, por sua vez, incorporada como um preconceito oriundo da Aufklärung, ao sustentar que apenas pela via da desarticulação da subjetividade situada a objetividade poderia ser atingida.

Conforme a leitura de Gadamer, a compreensão desenvolvida sobre os preconceitos pela Aufklärung ressalta como fundamento de sua origem o respeito à autoridade alheia, cuja referência fundamental encontra-se na formulação kantiana desenvolvida em "Beantwortung der Frage: Was ist Aufklärung?" ("Resposta à pergunta: O que é Iluminismo?”) de 1784: "Tenha coragem de servir de teu próprio entendimento" 240 . O horizonte de aplicação desse princípio, além da compreensão dos textos, estende-se também ao âmbito hermenêutico, situando-se como contrário à interpretação dogmática de tradição religiosa da Sagrada Escritura. O problema hermenêutico central que aí se põe provém da tendência geral da Aufklärung em neutralizar qualquer que seja a valência de autoridade alheia ao tribunal da razão. Desse princípio, segue-se uma relação de enfrentamento da Aufklärung com a tradição

\footnotetext{
${ }^{239}$ Segundo Gadamer, o que justifica uma análise sobre o conceito de preconceito, considerando o descrédito que este sofreu ao longo da Aufklärung, é a própria necessidade de identificar-se as dificuldades de compreender o conhecimento histórico em sua essência. $\mathrm{O}$ interesse hermenêutico de esclarecer esse descrédito surge, dessa forma, como ponto de partida para essa análise.

${ }^{240}$ H.-G. GADAMER, $W M$, I, p. 276.
} 
(Traditon) $)^{241}$ e, conseqüentemente, com a história. O caráter de autoridade, outrora conferido aos documentos históricos, à verdade dos escritos, é então assimilado como um preconceito do qual devemos liberar-nos mediante o esforço crítico da razão. Verifica-se o deslocamento de autoridade da tradição para a razão, donde se segue que "[...] toda tradição (Überlieferung) que se revela ante a razão como impossível ou absurda só pode ser entendida como histórica, isto é, retrocedendo às formas de representação do passado"242. O que aqui se mostra é a revalorização hermenêutica da autoridade e da tradição. Revalorizar a autoridade no sentido de resgatá-la de uma função autoritária assumida no Iluminismo, atribuindo-lhe o caráter de formação histórica e síntese de sentido que nunca se impõe para além do alcance da razão. Afinal não é a razão que depõe em favor da historicidade, mas, bem pelo contrário, é ela que se constitui como o lugar em que a razão encontra sua validez distanciada do domínio de um saber absoluto. Por conseguinte, a tradição (Tradition) também é reabilitada, pois ela, enquanto fio condutor da temporalidade, é pura transmissão e fonte de preconceitos legítimos. Guardiã da razão e da liberdade, é o lugar-comum em que vivemos sob a escuta de "uma pluralidade de vozes nas quais o passado ressoa" ${ }^{243}$.

Superar os limites dessas considerações acima expostas sobre a relação do preconceito com a autoridade relaciona-se diretamente à tentativa gadameriana de reconstruir uma hermenêutica histórica, cuja matriz fundamental está numa compreensão adequada da finitude, característica do ser humano, bem como de sua consciência histórica. Nesse sentido, a razão só pode ser tomada, em sua radical existência real e histórica, no horizonte de suas referências no qual estamos necessariamente inseridos. Afirma Gadamer: "Não é a história que pertence a nós, mas nós é que a ela pertencemos [...] antes que nós compreendamos a nós mesmos na reflexão, já estamos nos compreendendo de uma maneira auto-evidente na família, na sociedade e no Estado em que vivemos"244. Isso significa que a autoridade subjetiva da auto-reflexão está condenada à fragilidade, se desconsidera a própria corrente da vida histórica. Desenvolvendo o "preconceito contra os preconceitos", esta reflete tãosomente uma deformação da realidade, privando-a, conseqüentemente, de seu caráter essencialmente histórico.

\footnotetext{
${ }^{241}$ Orientando-se pelos seus estudos humanísticos e por sua aproximação à Heidegger, Gadamer não apenas desenvolve um diálogo com a tradição, bem como o seu significado assume um caráter paradigmático para a compreensão de sua hermenêutica filosófica. O que em nossa língua denominamos de "tradição" corresponde a dois termos usados por Gadamer: Tradition e Überlieferung. Tradição vem do latim traditio, cujo significado é "entrega, transmissão". A expressão Überlieferung provém de überliefern, ou seja "transmitir" e de liefern que corresponde a "prover, entregar".

${ }^{242}$ Id., ibid., p. 280.

${ }^{243}$ Id., ibid., p. 289

${ }^{244}$ Id. ,ibid., p. 281.
} 
A proposta de Gadamer aponta, portanto, para uma "reabilitação dos preconceitos" como viabilidade para uma verdadeira compreensão, em detrimento de uma autoconstrução absoluta da razão. O reconhecimento dessa tarefa assim se constitui como condição de possibilidade de construir uma hermenêutica verdadeiramente histórica que faça justiça ao ser humano no caráter de sua finitude e historicidade.

Independentemente de seu modo de constituição, a história, como as demais ciências humanas (Geisteswissenschaften), tem sua compreensão sempre articulada, interpelada ou mesmo compartilhada, à sobrevivência das tradições. Nas investigações históricas, mesmo considerando-se os novos interesses e questionamentos de quem investiga, parecem ser sempre operantes os momentos e conteúdos da tradição com vistas a atingir um nível de significação para sua tarefa. Por isso, afirma Gadamer, há um efeito recíproco entre a tradição e a investigação, ou seja, "o efeito da tradição que sobrevive e o efeito da investigação histórica formam uma unidade de efeito, cuja análise só poderia encontrar uma trama de efeitos recíprocos" 245 . O que aqui nos parece fundamental para o problema da hermenêutica histórica é o sentido em que é proposta a reabilitação da tradição, identificando-a como momento integrante ao comportamento histórico, cuja produtividade hermenêutica abre-se aos efeitos da diversidade de investigações.

Motivados pelos interesses de seu próprio presente, a investigação das ciências humanas promove constantemente um regresso à tradição. Nossa consciência histórica compraz-se remetendo-nos sempre ao passado, que, sob uma diversidade de vozes, ressoa e dá o testemunho de nosso inevitável pertencimento à tradição; nela participamos porque também assim queremos. A autocrítica da consciência histórica, além de investigativa, é também mobilidade histórica, mediação da tradição, mediação histórica do passado com o presente, e que se expressa no próprio movimento de compreender. Como bem afirma Gadamer: "O compreender deve ser pensado menos como uma ação da subjetividade do que como um retroceder que penetra em um acontecer da tradição" ${ }^{246}$. Conforme já observado, essa consideração tem como referência fundamental a mudança decisiva resultante da descrição e fundamentação existencial do "círculo hermenêutico" desenvolvida por Heidegger. Segundo este, o círculo da compreensão, cuja estruturação é ontológica, e não metodológica, é determinado pela estrutura prévia da pré-compreensão e descreve a compreensão tanto como interpretação subjetiva do intérprete, quanto do movimento objetivo da tradição. As antecipações prévias de sentido não podem ser entendidas, nesse sentido, como exclusivos

\footnotetext{
${ }^{245}$ Id., ibid., p. 287.

${ }^{246}$ Id., ibid.,p. 295.
} 
atos de subjetividade, pois resultam de nossa relação de comunhão com a tradição, em contínua formação. Do ponto de vista do círculo hermenêutico, a tradição, além de um fator de produtividade a partir do qual pré-juízos são projetados continuamente, também é o lugar em que se desenvolve a investigação. Nesse sentido pretender elevar todas as nossas projeções do compreender à transparência da consciência, fazendo-as depender de uma subjetividade autônoma e absoluta, seria arriscar-se a cair nas armadilhas de um pensamento instrumental e metódico da subjetividade. Apenas compreende aquele que, inevitavelmente, deixa-se conduzir por expectativas e compreende-se pelos efeitos da história (Wirkungsgeschichte). Alguém que compreende, portanto, pertence a uma história que atua nele, embora não seja devidamente consciente disto. Eis o que se põe não como obstáculo, mas como condição de possibilidade do próprio compreender.

Mesmo decisivamente influenciado pela discussão heideggeriana sobre o "círculo hermenêutico", convém ressaltar, a esse propósito, uma orientação diferente desenvolvida por Gadamer. Enquanto toda a análise heideggeriana advém de uma motivação existencial, isto é, ao buscar compreender-se, o Dasein põe em jogo o reconhecimento de uma antecipação que, por sua vez, visa a esclarecer a interpretação, a tônica de Gadamer parece estar essencialmente voltada para sua crítica contra o modelo metodológico da objetividade que nivela o fenômeno do compreender, neutralizando o caráter de pertencimento do intérprete tanto ao objeto quanto à tradição. No entanto, é a reflexão heideggeriana sobre a estrutura prévia do compreender que ilumina o caráter ontológico dessa relação de pertencer. Essa concepção Gadamer intenciona pô-la a serviço de uma hermenêutica própria para as ciências humanas. Por isso, enquanto Heidegger refere-se à problemática do círculo destacando as antecipações existenciais previamente entendidas, Gadamer confere-lhe um caráter mais concreto, deslocando-se para a esfera da interpretação dos textos, que, embora mais restrita, é mais próxima ao âmbito das ciências humanas. Além disso, se a noção do compreender como projeção a partir da procedência das antecipações remete-nos a uma idéia de futuro, em Gadamer a reabilitação dos preconceitos (Vorurteile) enquanto conteúdo da pré-estrutura do compreender envia-nos à primazia do passado, da tradição. Enquanto uma pluralidade de vozes silenciosas, a tradição exige do intérprete que busca compreender uma participação ativa, de modo que possa exercitar a escuta e o deixar-se interpelar pela tradição.

É preciso ter a clareza de que o comportamento histórico-hermenêutico não pode ignorar o fato de que todo aquele que compreende vincula-se, necessariamente, a alguma coisa, cuja expressão determina-se em sua conexão com a tradição. A tradição transmite-se e deixa-se falar pelas coisas que buscamos compreender. Por isso, a tarefa hermenêutica do compreender 
determina-se sob a base de uma polaridade, de uma tensão, entre a estranheza e a familiaridade. É precisamente nesse entremeio (Zwischen) entre a objetividade da distância histórica e o pertencer a uma tradição que a hermenêutica reconhece o seu lugar, diz Gadamer.

Conforme vimos anteriormente, Gadamer, a partir de Heidegger, vincula a compreensão à antecipação da estrutura preconceptual, o questionamento crítico de sua hermenêutica filosófica; por sua vez, interroga como torna-se possível chegar a esboços prévios adequados à realidade; como distinguir os verdadeiros dos falsos preconceitos, de modo que sejam evitados os mal-entendidos. Vale ressaltar que a discussão em torno da questão da verdade evidencia-se precisamente, dada a inexistência de critérios capazes de assegurar esse propósito de objetividade. No entanto, sustenta Gadamer, ao exercitarmos um olhar histórico retrospectivo, criamos condições e possibilidades de reconhecer ou não a comprovação dos princípios de interpretação. É através da "distância histórica", considerando os indícios subsistentes na produtividade dos intervalos do tempo, que a formulação dos juízos garante uma maior seguridade. No cumprimento da tarefa hermenêutica de identificar e esclarecer as condições sob as quais surge a compreensão sobressai o caráter de fecundidade da "distância temporal".

Como bem afirma Gadamer: "Nada além do que essa distância de tempo torna possível resolver a verdadeira questão da crítica hermenêutica, ou seja, distinguir os verdadeiros preconceitos, sob os quais compreendemos os falsos preconceitos que produzem os malentendidos" 247 . É o princípio da distância temporal (Zeitenabstand) fazendo prevalecer à consciência hermenêutica seu reconhecimento como consciência histórica e conferindo à tradição o direito de sobressair mediante o processo de consciência dos próprios preconceitos. Em outras palavras, é o próprio caráter questionável do preconceito, mediante seu exercício, que nos permite experimentar a pretensão de verdade do outro. Daí a retomada de uma condição máxima da hermenêutica filosófica, qual seja, “a compreensão começa aí onde algo nos interpela" ${ }^{, 248}$. Encontrar-se com a tradição é fazer valer a alteridade, tornar suspensos

\footnotetext{
${ }^{247}$ H.-G. GADAMER, WM, I, p. 304. Sobre essa passagem é interessante o comentário feito por Jean Grondin sobre o que poderia tornar-se um caráter unilateral dessa afirmação, já que nem sempre de forma tão produtiva pode-se apresentar a distância temporal. Diz-nos Grondin: “[...] um heideggeriano como Gadamer sabe muito bem que a história atua muito seguidamente de modo encobridor, e, por isso, com demasiada freqüência se afirmam princípios de interpretação que obstruem o acesso às coisas ou às fontes. Às vezes, é precisamente o salto para trás das interpretações historicamente poderosas que é hermeneuticamente enriquecedor [...] O próprio Gadamer reconheceu recentemente a unilateralidadde de seu princípio nesta questão. Quando Verdade e método, em 1985, apareceu em quinta edição nas obras completas, ele retocou a passagem correspondente e substituiu o 'nada mais além...' por um 'Freqüentemente a distância temporal é capaz de tornar solúvel a questão da crítica hermenêutica"” (J. GRONDIN, Introdução à hermenêutica filosófica, p. 189).

${ }^{248}$ H.-G. GADAMER, $W M$, I, p. 305.
} 
nossos preconceitos, mantendo sob a estrutura lógica da pergunta uma abertura a outras possibilidades.

\subsubsection{O princípio de Wirkungsgeschichte e sua noção de consciência histórica}

Uma reflexão, ao comprometer-se com o verdadeiro compreender, sustenta Gadamer, não pode, nem em benefício de uma ilusória confiança em um metodologismo, ou mesmo de um objetivismo histórico, omitir sua própria historicidade. Conhecer historicamente o objeto é, portanto, buscar apreender o que há de diferente neste, pois "o verdadeiro objeto histórico não é um objeto, mas a unidade de um e de outro, uma relação na qual permanece tanto a realidade da história como a realidade do compreender histórico"249.

Por isso, uma hermenêutica verdadeiramente adequada a seu objeto investigativo deve mostrar, na própria compreensão, a realidade da história. O que torna, por exemplo, a arte um objeto histórico não é simplesmente o produto artístico propriamente dito, mas também suas diferenças em relação a ele mesmo, a verdadeira realidade de sua compreensão histórica. Compreender é, pois, submeter a investigação dos objetos ao princípio da "história dos efeitos" (Wirkungsgeschichte), ou seja os efeitos destes na história.

Como lembra Grondin, o desenvolvimento dessa concepção de consciência da história (Wirkungsgeschichte) indica o propósito gadameriano de pensar o fenômeno da compreensão em consonância com a questão da objetividade nas ciências do espírito (Geisteswissenschaften). A noção de história dos efeitos remonta ao século XIX, referindo-se ao estudo de interpretações produzidas por uma época. Designa uma disciplina cujo interesse era a continuada influência da recepção de obras ou acontecimentos. Sob esse propósito tratase de uma reflexão articulada por uma consciência histórica cuja tarefa compromete-se com o real significado de uma obra outrora constituída na tradição. Seu interesse concentra-se, portanto, na acolhida e recepção compreensiva das obras no horizonte de seus efeitos e influência.

Para Gadamer, porém, a história dos efeitos (Wirkungsgeschichte) não corresponde apenas à história da recepção, da qual se pode obter um conhecimento objetivo, mas a uma compreensão de história que nunca se torna plenamente evidente, pois nela se encontra uma consciência de seus próprios efeitos. A consciência histórica é aquela consciência produzida

\footnotetext{
${ }^{249}$ H.-G. GADAMER, WM, I, p. 305.
} 
pelos efeitos da história. Em sua formulação terminológica, a expressão Wirkung designa o fato de que o próprio movimento de atuação da história até mesmo onde seus efeitos não são perceptíveis. Wirkungsgeschichte significa não apenas o processo de ação da história, como também seu resultado, nossa consciência sobre ela: a consciência histórica. É um seguir atuando da história para além da consciência que podemos ter dela.

Ora, dado que a distância histórico-temporal determina nossa própria condição hermenêutica, compreender um fenômeno histórico significa, necessariamente, inserirmo-nos no conjunto de seus efeitos. "Ela determina de antemão o que se mostra a nós de questionável e como objeto de investigação, e nós esquecemos logo a metade do que realmente é; mais ainda, esquecemos toda a verdade desse fenômeno, a cada vez que tomamos o fenômeno imediato como toda a verdade" ${ }^{, 250}$.

Assim, à ingenuidade da compreensão, característica de um objetivismo históricocrítico, peculiar ao historicismo, que oculta e nega as pressuposições sustentadoras e orientadoras do compreender, contrapõe-se o entrelaçamento histórico-efeitual inerente à consciência histórica, cuja urgência impõe-se como exigência necessária à consciência científica. Não se trata, porém, adverte Gadamer, de uma exigência disciplinar da história dos efeitos (Wirkungsgeschichte), como uma proposta de auxílio às ciências humanas "[...] mas que se aprenda a conhecer-se melhor a si mesmo e se reconheça que os efeitos da história dos efeitos operam em toda compreensão, esteja ou não consciente disso" ${ }^{, 251}$.

Independentemente de seu reconhecimento, essa compreensão da história, em sua relevância, impõe-se à consciência científica, já que o caráter histórico conceitual da consciência constitui um momento da realização de nossa compreensão, integrando a condição à situação em que esta se desenvolve. Desse modo, a noção de Wirkungsgeschichte corresponde, antes que tudo, a uma consciência da "situação" (Situation) do compreender e interpretar - consciência da situação hermenêutica.

É inegável que sempre nos encontramos em uma situação, e não diante dela, no sentido de podermos produzir um saber absoluto a seu respeito. Assim é que, em situação, encontramo-nos em face da tradição que queremos compreender. Mas, se o conceito de "situação" determina-se e representa justamente a posição que limita as possibilidades de ver algo, correlato a este está o conceito de "horizonte" (Horizont), ou seja, "o âmbito de visão que abarca e encerra tudo o que é visível a partir de um determinado ponto" ${ }^{252}$. Esse conceito

\footnotetext{
${ }^{250}$ H.-G. GADAMER, $W M$, I, p. 305

${ }^{251}$ Id., ibid., p. 306

${ }^{252}$ Id., ibid., p. 307.
} 
apresenta uma significação dinâmica na medida em que nos remete à sua possibilidade de abertura, estreitamento ou mesmo ampliação. Ter um horizonte implica a capacidade de ultrapassar as fronteiras do que se mostra mais próximo, vislumbrando ir mais além. Por meio dos conceitos de "situação" e "horizonte" parece ficar ainda mais claro que ação da história dos efeitos (Wirkungsgeschichte) não está em nosso poder, nem tampouco à nossa disponibilidade, pois o registro de sua presença está em toda parte onde compreendamos.

Afirma Gadamer: "A elaboração da situação hermenêutica significa então a obtenção do horizonte de questionamento correto para as questões que se põem diante da tradição" $" 253$. A hermenêutica filosófica de Gadamer é, portanto, uma hermenêutica de vigilância histórica, porque a tarefa de sua compreensão histórica busca ver o passado em seu próprio ser. Portanto, prescindir de seu próprio horizonte, omiti-lo, é negá-lo enquanto elemento preponderante do diálogo; é distorcer a exigência hermenêutica de que entender o outro é situar-se em seu lugar e predispor-se a conhecer o horizonte de sua diferença e alteridade. Se é inerente ao ser humano a predisposição contrária a uma vida essencialmente solitária, absoluta e fechada, isto se dá exatamente porque, enquanto horizonte, determina-se pela mobilidade do seu existir, pelo deslocamento que a existência humana perfaz nas próprias trilhas de seu caminho. Logo, o remeter-se a um horizonte histórico em que vive uma tradição passada não significa um deslocamento a um horizonte estranho. A profundidade de nossa autoconsciência em seu movimento ultrapassa os limites e as fronteiras do próprio presente, de modo que "o passado próprio e estranho, ao qual se volta a consciência histórica, forma parte do horizonte móvel a partir do qual vive a vida humana e que a determina como sua origem e como sua tradição" 254 .

A compreensão da tradição, contudo, pode requerer a consciência de um horizonte histórico, mas disso não se segue que esse horizonte seja adquirido mediante um deslocamento $^{255}$ a uma situação histórica. Ganhar um horizonte mediante um deslocamento significa ascender a uma universalidade, a uma visão mais ampla que ultrapassa a esfera das particularidades. Daí que deslocar-se não corresponde a submeter-se a, mas integrar-se de modo que se veja além daquilo que se mostra próximo. Isso também justifica o fato de que

\footnotetext{
${ }^{253}$ Id., ibid., p. 308.

${ }^{254}$ Id., ibid., p. 309-10.

${ }^{255}$ No sentido de melhor esclarecer o sentido de horizonte histórico, Gadamer apresenta uma ponderação conceitual sobre o conceito de "deslocamento". Embora signifique um dirigir-se a uma situação diferente, o que satisfaz o real sentido do deslocar-se é o autoconduzir-se a essa situação. "Se nos deslocamos, por exemplo, à situação de um outro homem, então vamos compreendê-lo, isto é, tornar-nos-emos conscientes de sua alteridade, e até de sua individualidade irredutível, precisamente por nos deslocarmos à situação" (id., ibid., p. 10).
} 
uma consciência verdadeiramente histórica não pode prescindir da situação presente; é necessário ver-se no conjunto de suas relações entre si mesma e o historicamente outro.

Desse modo, a partir da noção de situação hermenêutica, tomamos consciência de que somos determinados por nossos preconceitos, mas não podemos limitar-nos a esse horizonte presente como um acervo fixo de idéias e valores. Dado o caráter dinâmico de nosso horizonte, integra seu processo de formação o procedimento de pôr à prova suas prévias concepções, mediante o remeter-se ao passado, o dirigir-se ao encontro com a tradição. E, como, para Gadamer, não tem sentido falar-se em horizontes presentes em sua autonomia, nem também em horizontes históricos a serem ganhos, o ato de compreender resulta "[...] sempre em um processo de fusão desses horizontes presumivelmente dados por si mesmos"256. Ora, entender essa noção de fusão de horizonte (Verschmelzung), dada a inexistência de horizontes que se destacam ${ }^{257}$ uns dos outros, conduz Gadamer a desenvolver uma maior explicitação do conceito de "situação". Portanto, é na peculiaridade da noção de "situação", na medida em que esta se converte em "situação hermenêutica", que a compreensão, ao projetar-se em seu horizonte histórico, assume o status de tarefa científica.

$\mathrm{O}$ desdobramento dessa consciência histórica que faz sobressair o encontro com a tradição experimenta uma relação de tensão a ser desenvolvida e que não pode ser ocultada. Sendo a consciência histórica consciência de sua própria alteridade, ela, ao destacar o horizonte da tradição, o faz com respeito a seu próprio, determinando-se, ou melhor, superposicionando-se, sobre uma tradição que permanece atuante; eis o que perfaz sua própria intermediação. Assim, o que confere cientificidade à compreensão hermenêutica ${ }^{258}$ é a peculiaridade mediante a qual esta cumpre a tarefa da consciência histórico-efeitual. Essa noção de Wirkungsgeschichte recobra em nós a possibilidade real de sua vigilância. Ser consciente é estar desperto e vigilante; é manter-se desperto, aberto ao mundo, estando presente e, ao mesmo tempo, remetido ao horizonte da tradição.

\footnotetext{
${ }^{256}$ H.-G. GADAMER, $W M$, I, p. 311.

${ }^{257}$ Ouvir a tradição em seu sentido próprio e diferente implica sua realização sob a forma de um processo de "destacar" (Abhebung). Segundo Gadamer, o conceito de "destacar" indica sempre uma relação de reciprocidade. A pretensão de destacar-se então implica um destacar-se de algo, que, por sua vez, tem que destacar-se daquele. $\mathrm{O}$ jogo dos preconceitos ilustra bem essa significação, na medida em que em face do horizonte do presente, em que os preconceitos se formam, o horizonte do passado, em sua alteridade, destaca-se como fundamento.

${ }^{258}$ Com o objetivo de exemplificar a circularidade da compreensão no caráter de sua historicidade Gadamer encontra no conceito de "clássico" seu modelo ilustrativo. Ele constitui-se como exemplo de fusão de horizontes em que não só a tradição é conservada, mas também sua mediação é realizada entre passado e presente. O clássico aqui é tomado não no sentido de uma reabilitação estritamente normativa de seu conceito, mas em uma dimensão histórica. Seu objetivo é tão-somente mostrar que um elemento normativo nunca desaparece por completo da consciência histórica. "O clássico é uma verdadeira categoria histórica por ser mais do que o conceito de uma época ou o conceito histórico de um estilo, sem que por isso pretenda ser uma idéia de valor super-histórico" (Id., ibid., p. 291).
} 
Assim desenvolvido, esse exame feito por Gadamer acerca do condicionamento histórico-efeitual tem também como foco sua controvérsia com a consciência metódica moderna e também com o historicismo. Este último, apelando para seu método crítico, pensava poder escapar de todo condicionamento histórico, mantendo à distância a história que o determina. O equívoco desse procedimento, conforme assinala Gadamer, é que, diante da ingenuidade de uma fé metodológica, ocultar o entrelaçamento histórico-efeitual desenvolvido pela consciência histórica resulta na deformação do próprio conhecimento. Para o historicismo, em contrapartida, o desenvolvimento de uma consciência histórica deveria significar a própria emancipação de seu condicionamento com vistas a viabilizar uma fase objetiva da história.

O registro da história dos efeitos como princípio inerente à compreensão histórica, além de qualificar a hermenêutica essencialmente como histórica, também instaura na análise de Gadamer a reconquista do fenômeno hermenêutico básico pela reconsideração ${ }^{259}$ do problema da "aplicação". Atenta à mobilidade histórica da compreensão, a hermenêutica histórica, em vez de indicar o método de aproximação objetiva do objeto, constitui-se bem mais como um processo que nos insere em um acontecer tradicional. Como resultante desse procedimento, nossas interpretações, por sua vez, não se restringem a um simples deciframento ou a um fundamentar-se na individualidade do outro ${ }^{260}$. A acuidade do problema hermenêutico não está em considerar de modo separado o intérprete, no horizonte mesmo de sua subjetividade e, por outro lado, a objetividade de sentido a ser compreendida; isso seria para o hermeneuta negar a própria dialética do subjetivo com o objetivo. A compreensão hermenêutica não se constitui como um saber dominador com vistas a apoderar-se, já que está sempre submetida a uma pretensão objetiva e determinante. "O milagre da compreensão consiste, antes, no fato de que não é necessária a congenialidade para reconhecer o que é verdadeiramente significativo e

\footnotetext{
259 Do ponto de vista da tradição hermenêutica, a problemática da compreensão apresentava um caráter sistemático, distinguindo-se em três momentos indicativos de um fazer espiritual distinto: a compreensão (subtilitas intelligendi), a interpretação (subtilitas explicandi) e posteriormente, com o pietismo, a aplicação (subtilitas applicandi). No momento em que no romantismo é reconhecida a unidade entre compreender e explicar, a correlação de significado entre estas - compreender é interpretar, e vive-versa -, o momento da aplicação é desconectado enquanto momento de problemática hermenêtica; como se a aplicação não se constituísse como um momento integrante no processo de compreensão e interpretação. Sobre essa questão, convém ainda registrar, enquanto elemento de análise apontado por Gadamer, que o desenvolvimento da noção de consciência histórica nos séculos XVIII e XIX sustentava o desatrelamento da hermenêutica filológica e a historiografia de outras disciplinas hermenêuticas, como a teológica e a jurídica, para as quais compreender é sempre aplicar.

260 Desse modo se baseava, segundo Gadamer, a interpretação psicológica desenvolvida pela hermenêutica romântica responsável pela fusão entre interpretar e compreender.
} 
o sentido originário de uma tradição. Somos, antes, capazes de abrir-nos à pretensão excelsa de um texto e corresponder compreensivamente ao significado com o qual nos fala”,261.

A história é um processo contínuo e sempre influente, cuja consciência é um momento de realização da compreensão que se mantém sempre renovado. Como vimos, cada situação exige que o intérprete interrogue seu próprios pré-conceitos, determinando-se assim como consciência de finitude e de pertencimento a uma tradição. Isso confere à consciência histórica uma tarefa, um esforço contínuo de manter-se, um não esgotar-se, atualizando-se sempre. Diante disso, Gadamer reconhece, nessa mobilidade histórica da compreensão, um problema fundamental de aplicação ${ }^{262}$. Ao recuperar esse conceito, Gadamer, além de enfatizar que a compreensão tem seu fundamento na historicidade - pois não pode ignorar os preconceitos e a tradição, a idéia de um conhecimento ou experiência prévia -, recupera na idéia da phronesis aristotélica o fato de que o homem não dispõe de si mesmo. Enquanto Dasein, o homem é um ser em constante construção e sempre está inacabado, por isso essa sua permanente tarefa não pode dispensar sua atividade prática no processo de autocompreender-se. No conceito de aplicação, portanto, reúnem-se os dois momentos nucleares da compreensão; o passado a ser compreendido e o presente em que o intérprete é sempre interpelado ao proceder a sua interpretação. Nesse sentido, o homem que compreende é, fundamentalmente, aquele que é gerado pela consciência histórica; aquele que, não interpretando fora da situação, deixa-se afetar por ela em seu caráter histórico e concreto.

Até mesmo as interpretações reprodutivas, como no caso da música e da poesia, ressalta Gadamer muito dificilmente podem ser consideradas como uma forma autônoma de interpretação. Encenar um drama, recitar um poema, executar uma peça musical requer sempre a compreensão do sentido original do texto, referência basilar de sua interpretação. Assim é que toda interpretação, necessariamente, inclui aplicação, cuja validade de sentido tem o mesmo nível de importância que a "distância temporal" (Zeitenabstandes) como condição de possibilidade para a compreensão. Compreensão e aplicação coincidem. Trata-se de aplicar um sentido à nossa compreensão, motivada por nossos próprios questionamentos.

\footnotetext{
${ }^{261}$ H.-G. GADAMER, $W M$, I, p. 316.

${ }^{262}$ Reconhecendo a importância fundamental do conceito de "aplicação" para a hermenêutica, Gadamer recupera a significação do conceito aristotélico de "aplicação" quando este mostra, na Ética a Nicômaco, a distinção entre phronesis (saber moral) e episteme (saber teórico). Esse primeiro refere-se a um saber que não pode ser atingido mediante o recurso de uma techne, ou mesmo de acordo com um método objetivador. Ele exige um enfrentamento de situações práticas a serem vividas por aqueles a quem afetam diretamente; o saber epistêmico corresponde ao saber teórico puro, independente da experiência. Essa diferença também se mostra na medida em que se percebe que os homens não podem dispor de si da mesma forma que dispõem dos objetos. Os melhores resultados obtidos por um artesão dependem sempre de um maior conhecimento que ele tiver antes mesmo de aplicar uma techne à coisa. Já no tocante à phronesis, para a consciência moral, o conjunto de experiência ou mesmo a pressuposição de um conhecimento teórico jamais é suficiente para uma decisão moralmente correta.
} 
Eis o motivo pelo qual, Grondin ${ }^{263}$ nos diz que a compreensão não se limita a uma reprodução, e sim a uma conduta produtiva de aplicação que se diversifica nas épocas históricas. Daí que a aplicação, ao deixar-se conduzir pela história dos efeitos, decorre bem menos da auto-suficiência subjetiva do que do inserir-se num acontecimento da tradição. Da mesma forma, compreender a experiência de verdade como abertura de sentido (aletheia) só é posível no decurso da aplicação histórico-efeitual.

\subsection{O caráter de atualidade da arte e sua experiência festiva}

Ao tratarmos anteriormente da experiência ontológica da arte, afirmamos que essa análise constitui, para a hermenêutica filosófica, uma condição fundamental para pensarmos a experiência da arte em sua função de verdade, na medida em que também nos remete à questão da atualidade do belo. Assim, naquele primeiro momento nos ativemos às considerações pertinentes à estrutura do modo de ser da obra de arte, mas a proposta agora é desenvolvermos um prolongamento desta análise ontológico-hermenêutica. Tendo em vista a compreensão sobre o significado da idéia de história dos efeitos (Wirkungsgeschichte), como justificar a pretensão de verdade da arte enquanto declaração atualizada? Em que medida o caráter festivo de sua temporalidade legitima seu testemunho de verdade na história? Para tanto, além da obra Verdade e método, também nos concentraremos em seu texto-conferência denominado A atualidade do belo (Die Aktualität des Schönen, 1975).

Diante do cenário da história da cultura, marcada por uma pluralidade de experiências e pela expressão de grandes individualidades e estilos, a pergunta pela arte, além de uma questão antiga $^{264}$, manteve e mantém sua freqüência no horizonte das especulações estéticas e filosóficas, inserindo-se na atualidade das discussões e controvérsias. O interesse hermenêutico-filosófico sobre a questão - o que é a arte em sua atualidade? - traduz-se como a indagação sobre o problema de sua legitimação ao longo da história, cuja abordagem é renovada "cada vez que uma nova pretensão de verdade contrapõe-se à forma tradicional que se propaga na expressão da invenção poética ou na linguagem formal artística"265. Desse

\footnotetext{
${ }^{263}$ C.f. J. GRONDIN, Introdução à hermenêutica filosófica, p. 185-205.

264 A seriedade dessa temática em sua abordagem antiga é feita por Gadamer num de seus estudos iniciais, intitulado "Plato und die Dichter", 1934, no qual o filósofo indica a origem histórico-filosófica em que a esfera da arte é confrontada com o problema de sua legitimação.

${ }^{265}$ H.-G. GADAMER, Aksch., p. 94. Enquanto ilustração: "Pense-se na cultura da Antiguidade tardia com sua sempre lamentada aversão às imagens. Nessa ocasião, quando as paredes começaram a cobrir-se com incrustações, mosaicos e ornamentos, os artistas da época queixavam-se de que seu tempo já havia passado [...]
} 
modo, a formação cultural que temos é também fruto das alterações, renovações e protestos oriundos do processo da história da arte.

Segundo Gadamer, uma retomada do percurso desenvolvido pela arte cristã da Idade Média, pela renovação humanista das produções artístico-poéticas greco-romanas, revela-nos o testemunho e reconhecimento de que nossa formação histórico-artística desenvolveu e sedimentou formas comuns para conteúdos comuns de nossa autocompreensão, pelo menos até o final do século XVIII; sendo apenas no século XIX que instaurou-se um advento transformista de cunho sociopolítico e religioso.

Assim, a primeira orientação que a questão da justificativa da arte assume como uma questão filosófica é, fundamentalmente, histórico-contextual. Em outras palavras, justificá-la como experiência de verdade é inserir-se no processo mesmo de seu surgimento enquanto declaração permanentemente atualizada, cuja compreensão conduz-nos ao caminho de regresso à tradição, inserindo-nos, conseqüentemente, num diálogo entre o antigo e o moderno. Nas reflexões estético-hermenêuticas de Gadamer, a arte não é uma atualidade independente do tempo, de modo que compreendê-la é também tomá-la enquanto situação inserida em uma fusão de horizontes históricos. Conforme vimos anteriormente, na qualidade de seres históricos, somos membros de uma cadeia ininterrupta graças a qual o passado nos interpela, inserindo-nos no vivo de um processo de transmissão histórica. Por isso, o passado e o presente confluem como via de busca de verdade, conferindo sentido aos momentos de ruptura entre o antigo e o moderno, entre o anterior e o presente.

De modo bastante explícito, a conferência intitulada "A atualidade do belo", como o próprio título determina, apresenta o propósito de discutir o problema da justificativa da arte no século XX de acordo com os fundamentos da hermenêutica filosófica, entre eles, a concepção heideggeriana de compreensão e $\mathrm{o}$ princípio da história efeitual (Wirkungsgeschichte). Em outras palavras, de que modo a análise ontológico-hermenêutica da arte apresenta-se como condição de possibilidade de pensar o fenômeno da arte moderna em sua verdade? Examinar o princípio de atualidade da arte significa, para Gadamer, assumir o caráter autocrítico e investigativo da consciência histórica, vislumbrando, na mediação histórica do passado com o presente, a própria atualidade do compreender. Consciência

Pense-se, sobretudo, na postura que adotou o cristianismo diante da tradição da arte que encontrou. Foi uma decisão de índole secular o rechaçar a iconoclastia que apareceu no desenvolvimento tardio da igreja cristã do primeiro milênio, principalmente nos séculos VI e VII. Naquela época a igreja encontrou uma nova significação para a linguagem formal dos artistas plásticos e mais tarde também para as formas de expressão da poesia e da arte narrativa que trouxe à arte uma nova legitimação. Era uma decisão consolidada, já que a linguagem formal tradicional só se podia em verdade legitimar no novo conteúdo da mensagem cristã" (id., ibid., p. 94-5). 
histórica não no sentido de assimilar uma postura erudita e metodológica, tornando-se consciente da diversidade de concepções de mundo, porém como "[...] uma espécie de instrumentação da espiritualidade de nossos sentidos que determina de antemão nossa visão e experiência da arte" ${ }^{, 266}$. Consciência cujo diferencial reflexivo neutraliza o que poderia ser a validez duradoura de nosso presente, tendo em vista a apropriação do horizonte de nossa alteridade histórica, em sua diversidade cultural.

Diante do fenômeno artístico, notadamente presente nas diversas culturas e tradições, a hermenêutica nos propõe a tarefa de refletir sobre a obra de arte em sua relação de pertencimento a seu mundo, porém não como simples objeto da consciência histórica, no sentido de identificá-la e elucidar seu sentido originário e tradicional. É fato inquestionável que a arte não se restringe apenas a coisa do passado, como também é evidente ser o propósito de uma hermenêutica histórica mostrar em que sentido a arte consegue ultrapassar a distância dos tempos, mantendo-se como declaração e presença de seu próprio sentido. Por isso, submeter a arte a uma experiência hermenêutica vislumbrando sua compreensão implica também submeter a essa tarefa o desenvolvimento de uma mediação histórica.

"Nossa vida cotidiana é um passar constante pela simultaneidade de passado e futuro" ${ }^{267}$. Nessa afirmação Gadamer faz-nos perceber que nossa espiritualidade define-se também como um projeto, horizonte aberto e, ao mesmo tempo, um retorno às lembranças ${ }^{268}$ do passado. De modo bastante enfático, para o hermeneuta, o que capacita a força e o impulso da arte moderna é a intimidade com a linguagem da tradição, por meio da qual tanto o artista produz suas novas determinações audaciosas, quanto o admirador mantém-se cercado pela simultaneidade de passado e presente, seja ao confrontar-se com uma peça do teatro ou da pintura moderna, seja em salas de museu, seja na arte de reprodução clássica. É pretensão filosófica da hermenêutica justificar que a essa concepção referente à consciência histórica associa-se a afirmação de que "o que vemos está aí e nos interpela diretamente como se fosse nós mesmos" ${ }^{269}$. Interpelar-nos como se fosse nós mesmos significa, nesse sentido, remeternos ao confronto com a simultaneidade de presente e passado, horizonte de nosso próprio reconhecimento.

\footnotetext{
${ }^{266}$ H.-G. GADAMER, Aksch., p. 102.

${ }^{267}$ Id.,ibid., p. 101.

268 "Mnemósine, a musa da memória, a musa da apropriação recordativa, que aí impera, é ao mesmo tempo a musa da liberdade espiritual. A memória e a recordação, que tomam a si a arte passada e a tradição de nossa arte e a audácia da nova experimentação [...] são a mesma atuação do espírito" (id., ibid.).

${ }^{269}$ Id., ibid., p. 23.
} 
Assim, desenvolver a questão da atualidade da arte significa do ponto de vista de seu procedimento reflexivo uma ponderação histórico-hermenêutica. Voltar-se a ela enquanto coisa mesma, nesse sentido, significa não apenas prender-se à imediatidade de suas configurações submetendo-se ao impacto de suas audaciosas manifestações, mas deter-se em uma autoconsciência de superação entre a tradição artística antiga e moderna. A compreensão do fenômeno da arte nunca é algo totalmente novo, porém um momento novo a partir da tradição. Se esta, conforme ressaltamos, é um fator de produtividade, é porque se constitui no lugar em que a investigação acontece. Por isso, a análise sobre o fenômeno da arte no caráter de sua atualidade tem sua viabilidade no horizonte de conciliação entre tradição e razão. Lembremos as palavras de Gadamer a esse respeito:

\begin{abstract}
"Na realidade, a tradição sempre é também um momento da liberdade e da história. Mesmo a tradição mais autêntica e venerável não se realiza naturalmente, em virtude da capacidade de permanência do que de algum modo já está dado, mas ainda necessita ser afirmada, assumida e cultivada. A tradição é, essencialmente, conservação [Bewahrung] e, como tal, nunca deixa de estar presente nas mudanças históricas. Sem dúvida, a conservação é um ato da razão, ainda que caracterizado pelo fato de atrair atenção sobre si" 270 .
\end{abstract}

Submeter a arte a uma interpretação hermenêutica exige do intérprete uma participação ativa na compreensão de seu ser, deixando-se interpelar por sua tradição. Eis o fio condutor que o remete a fundamentar suas descobertas. Considerando o que há de específico nessa abordagem gadameriana de explicitação da experiência da arte como o caráter fundamental de uma análise antropológica sob o viés da vigilância histórica, pensar filosoficamente a arte é inserir-se no recurso à tradição, reconhecendo-a como marca da nossa finitude.

É, pois, na tradição da filosofia que Gadamer busca inspiração para o desenvolvimento especulativo dessa problemática da arte. Já em Platão torna-se claro que a tarefa do filósofo baseia-se na tentativa de apreender, na idéia, o comum, buscando compreender suas diferenças e particularidades. Além disso, do ponto de vista hermenêutico, entender a questão da atualidade da arte implica submeter essa reflexão ao princípio da história dos efeitos, e o desenvolvimento desse propósito é pois realizado tomando-se como pressuposto básico a compreensão da arte como um fenômeno de caráter universal, ou seja, a arte do passado e a arte do presente têm de ser pensadas conjuntamente ${ }^{271}$. Desse modo a tradição filosófica da estética em algumas de suas diretivas e considerações é retomada e sucintamente

\footnotetext{
${ }^{270}$ H.-G. GADAMER, WM, I, p. 286.

${ }^{271} \mathrm{O}$ recurso para pensá-las conjuntamente tem como ponto de partida a exposição dos meios conceituais da estética filosófica, disponibilizados pela própria tradição filosófica e cuja primeira orientação é a retomada da significação histórico-conceitual da palavra arte.
} 
desenvolvida por Gadamer como meio auxiliar para analisar sua problemática proposta, qual seja, "em que sentido pode-se conduzir o que a arte foi e o que ela é hoje a um conceito comum que englobe as duas coisas?",272.

Numa primeira esfera de compreensão, a palavra arte constitui-se como um pressuposto que revela o que há de comum nesse diversificado horizonte histórico de expressões artísticas. Se em sua tradição grega a arte pertence ao conceito do saber e capacidade de produzir, de fabricação, o que confere sua particularidade é seu próprio desprendimento, sua liberação a seu próprio fazer ${ }^{273}$. A partir desse conceito geral de conhecimento, o que é distintivo da arte é que ela constitui um fazer imitativo, uma cópia. "A arte só é possível porque a natureza deixa ainda de sobra algo a configurar, em seu fazer plástico, deixa um espaço vazio de configuração ao espírito humano"274.

Vale lembrar que essa noção de imitação em nada se refere a uma imitação naturalista e realista. Como afirma Aristóteles na Poética, lembrado por Gadamer, o que torna a poesia mais filosófica que a historiografia é o fato de ela nos ensinar a ver o geral no âmbito do fazer e do sofrimento humano.

Numa segunda esfera de abordagem, a relação entre as palavras arte e belas-artes remete-nos à compreensão do conceito de belo, de modo que em suas expressões contemporâneas, escreve Gadamer, este ainda conserva algo da significação antiga - kallos. Desse modo, relaciona-se belo com aquilo que é reconhecido publicamente, com a bela moral, na medida em que esta se deixa representar e com um prazer desprovido de utilitarismo. Para Gadamer, a análise do problema da essência do belo ou mesmo da arte tem na orientação grega de que a ordem do kosmos representa a plasticidade do belo, um fundamento esclarecedor; isto se verifica, sobretudo, na abordagem desenvolvida pelo pensamento platônico no diálogo chamado Fedro. A predestinação humana tem um duplo horizonte: sua submissão à existência física e instintiva e sua conseqüente limitação diante do divino. Descreve-se uma viagem sob a forma de um cortejo de todas as almas ao verdadeiro mundo, mundo de configurações permanentes do ser. Nesse encontro as visões das almas são acometidas de uma perturbação, pois apenas de forma furtiva e momentânea têm acesso às ordens eternas. Precipitadas ao mundo terreno, afastam-se da verdade cuja lembrança elas

\footnotetext{
${ }^{272}$ H.-G. GADAMER, Aksch., p. 110.

${ }^{273}$ Diz Gadamer: “A obra como ponto objetivo intencional de um esforço de trabalho regulamentado é posta em liberdade como aquilo que ela é, e liberada da associação com o fazer da fabricação. Pois a obra, por definição, é destinada ao uso" (id., ibid., p. 103).

${ }^{274} I d$., ibid., p. 104.
} 
guardam muito vagamente. Mesmo sem asas e impossibilitadas de dirigir-se às alturas, é possível uma nova experiência de elevação. Trata-se da experiência do amor e do belo, da vivência do amor e da percepção do belo e do verdadeiro. O belo, aquilo que mais brilha e atrai, constitui-se, portanto, como condição de possibilidade de, inserido no mundo das contingências, lembrar do verdadeiro. Essa luz da verdade pela qual percebemos o belo na natureza e na arte.

O que há de fundamental nessa descrição platônica é "que a essência do belo justamente não consiste em estar em frente e diametralmente oposto à realidade, [...] a beleza [...] é como uma fiança de que, com toda a desordem do real, com todas as imperfeições [...], o verdadeiro, contudo, não jaz inalcançável à distância, mas está a nosso alcance. É função ontológica do belo cobrir o abismo entre o real e o ideal e o real”275. Essa significação pertinente à expressão belas-artes corresponde ao segundo aceno orientador para a reflexão acerca da problemática da atualidade da arte.

O terceiro passo reflexivo refere-se à criação da estética na história do pensamento filosófico. Seu tardio surgimento, no século XVIII, expressa uma orientação do próprio racionalismo desenvolvido sob as bases das ciências naturais desde o século XVII. Por isso, tanto a esfera do belo quanto a da arte são tomadas como expressões eminentemente subjetivas. Segundo Gadamer, pensar acerca dessas experiências tem como destinação uma reflexão sobre o além daquilo que é conceptível, daí o caráter paradoxal da formulação de Baumgarten denominada cognitio sensitiva ${ }^{276}$. As expressões do belo e da arte, em sua singularidade podem ser comprovadas como um cálculo particular a partir do mais universal; sua especificidade não se dá a partir de uma cadeia de relações. Como afirma Gadamer:

"Sua verdade [...] não consiste numa regularidade geral que se representa nela. Antes cognitio sensitiva quer dizer que também naquilo que aparentemente é apenas o particular da experiência sensorial e que sempre costumamos relacionar com um geral, subitamente, em vista do belo, algo nos prende e nos obriga a permanecer no que aí se apresenta individualmente" ${ }^{, 77}$.

Desse modo, justificar essa específica pretensão de verdade manifestada pelo diverso espectro das criações artísticas humanas é tarefa da estética filosófica no exercício crítico do seu pensar, atentando, fundamentalmente, ao caráter histórico-efeitual da compreensão hermenêutica sobre o fenômeno do belo e da arte.

\footnotetext{
${ }^{275}$ H.-G. GADAMER, Aksch., p. 106.

${ }^{276}$ Segundo Gadamer, pensar o conhecimento sensível do ponto de vista da tradição do conhecimento desde os gregos constitui um grande paradoxo. Isso se justifica porque o conhecimento propriamente dito só existe quando foi descartada a contingência sensorial subjetiva, em benefício da regularidade, da lei geral das coisas, da razão.

${ }^{277}$ H.-G. GADAMER, Aksch., p. 107.
} 
Do ponto de vista da tradição filosófica da estética e de sua reflexão moderna, adverte Gadamer, tanto não é possível falar de uma grande arte do passado quanto de uma arte moderna que se auto-afirme a partir de um repúdio a arte tradicional clássica. O que se entende como arte e assim denominamos compreende uma diferenciação bem objetiva de seu significado ao longo da história da cultura e do pensamento.

\begin{abstract}
"Quando nos transportamos [...] para a postura reflexiva e pensamos o que queremos dizer com arte [...], então se dá um paradoxo: quando enfocamos a assim chamada arte clássica, vemos que ela era uma produção de obras que não era entendida em primeiro plano como arte, mas como formas que se encontravam no meio religioso ou também no mundano, como uma decoração do próprio mundo em seus atos de destaque: o culto, a representação dos soberanos e outros. No momento em que a arte ganhou coloração própria [...] e que a obra de arte começou a existir por si mesma, desligada de todos os relacionamentos coma vida, e a arte tornou-se arte, ou seja, 'musée imaginaire', no sentido de Malraux, quando a arte nada mais quis senão ser arte, aí surgiu a grande revolução da arte, que cresceu na época moderna até o desligamento de todas as tradições de conteúdo imagético e de mensagens compreensíveis e tornou-se questionável para ambos os lados. Isto ainda é arte? E isto ainda quer ser arte de algum modo? O que há por detrás dessa situação paradoxal? A arte pode em algum tempo ser arte, nada mais que arte?"278.
\end{abstract}

Ora, quando Gadamer afirma que a questão central que sustenta sua análise sobre a atualidade do belo é o que é a arte?, não se trata em nosso entender de buscar uma definição precisa sobre o que seja esse fenômeno cultural, mas desenvolver uma reflexão que identifique essa experiência enquanto unidade, apesar de sua ampla diversidade. Compreender a unidade dessas configurações considerando a quebra formal de suas configurações e o paradoxo de suas tendências ${ }^{279}$ só é possível - conforme anteriormente ressaltamos -, segundo o hermeneuta, considerando "a base antropológica de nossa experiência de arte" Isso significa que pensar a arte em sua unidade só é possível levando em conta a radicalidade da experiência humana, a experiência da arte enquanto essencialmente experiência de finitude, cuja base antropológica é expressa pelos conceitos de jogo, símbolo e festa.

Quando, no exame de sua explicitação ontológico-hermenêutica, observamos que uma reflexão hermenêutica da arte está condicionada a sua retomada como experiência de verdade cujo fio condutor determina-se sob a forma de uma análise ontológica de sua própria experiência em obra. Assim, no âmbito de sua significação hermenêutica a arte foi então

\footnotetext{
${ }^{278}$ H.-G. GADAMER, Aksch., p. 110.

${ }^{279} \mathrm{O}$ problema da atualidade da arte, segundo Gadamer, solicita uma retomada dos pressupostos conceituais da estética clássica e uma análise desse fenômeno a partir da finitude humana. Esse é o caminho para a problematização e a compreensão de suas seguintes indagações: "Como se deve entender as rupturas formais da criação artística moderna, o jogo com todos os conteúdos que são levados a tal ponto, que nossas expectativas são rompidas freqüentemente? Como se compreenderá o que os artistas de hoje ou algumas tendências da arte moderna denominam antiarte - o happening? Como se compreenderá que Duchamp ofereça um objeto de uso, subitamente, e de modo isolado, e com isso exerça uma espécie de estímulo e choque estético? Não se pode dizer simplesmente: "Que desordem grosseira!" Duchamp descobriu com isso algo das condições da experiência estética" (id., ibid., p. 113).

${ }^{280}$ Id., ibid.
} 
associada não apenas à experiência lúdica do jogo (Spiel), mas também ao movimento de transformação do jogo em configuração (Gebilde), cuja representação possibilita-nos o conhecimento de nós mesmos. Tomada em seu modo de ser, a essência da arte reside em sua representação (Darstellung), por isso sua experiência implica, ainda, uma certa temporalidade, cuja reflexão desenvolve-se a partir da experiência da festa (Fest). Assim, além das experiências do jogo e de significação simbólica, a estrutura da arte, no caráter de sua presença, é pensada a partir da experiência humana da festa.

É enquanto acontecimento festivo que a obra de arte instaura uma temporalidade de duração àquilo que, aparentemente, se apresenta de forma passageira. Eis o que justifica o propósito de explicitar o conceito de festa como um elemento de análise hermenêutica sobre o caráter histórico-temporal do fenômeno da arte. A experiência da arte, vale lembrar, é necessariamente uma experiência histórica, cujo horizonte de mediação entre o passado e o presente determina essencialmente seu desvelamento como experiência de sentido e verdade.

Sendo a arte representação (Darstellung), isso significa que a unidade de seu ser refere-se necessariamente a um representar-se na mudança dos tempos e das circunstâncias, sem que com isso perca sua identidade. "O fato de que existem obras que se originam num passado, do qual penetram no presente como monumentos duradouros, ainda não torna o seu ser um objeto da consciência estética ou histórica. Enquanto mantêm-se em suas funções, elas são contemporâneas a todo e qualquer presente ${ }^{, 281}$. Sua identidade implica tanto não descartar os indícios de sua função originária, quanto todos os aspectos cambiantes que integram a variedade de suas configurações ao longo do tempo. A presencialidade específica do ser estético remete-nos à questão do caráter de sua temporalidade, à sua eterna presença sob a forma de simultaneidade. Trata-se, na verdade, de uma a-temporalidade enquanto determinação dialética que se contrapõe ao fundamento convencional da temporalidade.

Com efeito, quando se trata de compreender a temporalidade da arte, é também necessário atentar à significação de continuidade inerente ao próprio tempo, ou seja, à temporalidade existencial e histórica do próprio Dasein - o modo de ser da compreensão como temporalidade. Para tanto, a reflexão heideggeriana sobre a categoria do tempo (Zeit) é fundamental. Uma das intuições decisivas de Heidegger em Ser e tempo é a questão da temporalidade como horizonte da compreensão do ser. Desde o início de Ser e tempo a descoberta da existencialidade como perspectiva orientadora para a interpretação ontológica do homem afigura-se como uma determinação nuclear. A noção de existência, embora seja

\footnotetext{
${ }^{281}$ H.-G. GADAMER, WM, I, p. 125-6.
} 
distinta da noção de Dasein, é decisivamente tomada como guia na determinação da essência do homem. O movimento existencial de autocompreensão do Dasein o implica como um ente que se reporta ao ser, que se importa com o ser, que procura ser. Enquanto ser-no-mundo, não é simplesmente o que está aí, mas seu próprio poder-ser, sua estrutura de possibilidade, seus possíveis modos de ser. Mas, como seus traços ontológicos fundamentais são a existencialidade, a facticidade e a decadência, seu ser, inicialmente projetado como existência, determina-se como cuidado (Sorge). Cuidado no sentido de antecedência de si, já que é projeto e poder ser; isto é, enquanto um a priori necessário de abertura a antecipar o sentido do ser como temporalidade originária. Heidegger então desenvolve a questão da temporalidade enquanto sentido de ser do cuidado (Sorge). Essa temporalidade é exatamente o que confere sentido e torna possível essa abertura que já é, esse por-vir enquanto modalidade de pura realização do Dasein. "O tempo é originalmente como temporalização [Zeitigung] da temporalidade o que torna possível a constituição do cuidado [Sorge]. A temporalidade é, em sua essência, ekstática [ekstatisch]. A temporalidade temporaliza-se originalmente a partir do porvir. O tempo original é finito" 282 . Ao temporalizar-se, o tempo não apresenta o caráter de um ente ou mesmo de uma seqüência homogênea e indefinida; bem pelo contrário, refere-se aqui a um espaço de jogo no qual o Dasein pode ser. Dasein é tempo, bem como o ser é compreendido sob a luz do tempo. Do ponto de vista ontológico, essa temporalização não corresponde a uma sucessão, mas a unidade de configuração do próprio Dasein na circunstancialidade das ekstases. Ao dizer que a temporalidade é ekstatisch, Heidegger refere-se a ela como unidade de um "saindo de si", significando ainda "aquilo que move para fora". "O por-vir, o ser-sido, o presente manifestam o caráter fenomênico do "para si', do 'retorno a' e do 'deixar vir ao encontro de'. Os fenômenos do 'para', do 'de', do 'retorno a' e do 'junto' revelam a temporalidade como puro ekstatikon. A temporalidade é o fora de si originário, em e para si mesmo si mesmo" ${ }^{\text {283 }}$. Nesse sentido, a relação do homem com o tempo não se limita à dimensão prática de sua natureza cotidiana. Seu questionamento resulta da evidência de que o ser humano enquanto um ser-no-mundo permanece nele sob um modo privilegiado no tempo; daí a necessidade de considerá-lo a partir das determinações fundamentais do seu $\operatorname{ser}^{284}$.

O objetivo de Gadamer é, pois, identificar, com base nessa compreensão, o que define a temporalidade da arte. Na qualidade de representação, "por mais mudança e desfiguração

\footnotetext{
${ }^{282}$ M. HEIDEGGER, El ser y el tiempo, $\S 65$, p. 358.

${ }^{283}$ Id., ibid., § 65, p. 356.

${ }^{284}$ Id., "O conceito de tempo".
} 
que a representação venha a sofrer, permanece, contudo, a mesma. É isso justamente que perfaz a vinculabilidade de toda e qualquer representação, ou seja, o fato de conter ela mesma o reporte para com a configuração e de subordinar-se ao padrão de correção que daí deriva" ${ }^{285}$. A representação referente à Gebilde - transfiguração em obra -, ressalta Gadamer, converte-se naquilo que o hermeneuta denomina "caráter de repetição do mesmo"286, não implicando, todavia, a repetição de algo, mas a recondução de seu originário. Na tarefa de melhor entender o traço enigmático do tempo, Gadamer então nos insere na especulação acerca do significado da festividade. A festa parece dizer-nos bem sobre a experiência do tempo.

Da mesma forma que outrora abordamos o fenômeno cultural do jogo (Spiel) como movimento pelo qual o ser humano ultrapassa o mundo da natureza e mediante a expressão da vida poética instaura as grandes atividades arquetípicas da sociedade humana, a reflexão sobre a festa ${ }^{287}$ assume a mesma perspectiva de tratamento. Do ponto de vista de sua natureza e significado como fenômeno cultural, a festa refere-se à representação da própria coletividade, cuja significação remonta às representações sagradas das civilizações primitivas, aos rituais sagrados nas formas de suas realizações simbólicas e também místicas, assim como a comemoração dos acontecimentos nucleares da natureza. Como diz Huizinga:

\footnotetext{
"Algo de invisível e inefável adquire nela uma forma bela, real e sagrada [...] Os participantes do ritual estão certos de que o ato concretiza e efetua uma certa beatificação, faz surgir uma ordem de coisas mais elevada do que aquela em que habitualmente vivem. É executada dentro no interior de um espaço circunscrito sob a forma de festa, isto é, dentro de um espírito de alegria e liberdade. Em sua intenção é delimitado um universo próprio de valor temporário. Mas seus efeitos não cessam [...] $\mathrm{Na}$ época das grandes festas, o grupo social celebra os acontecimentos principais da vida da natureza levando a efeito representações sagradas, que representam a mudança das estações, o surgimento e declínio dos astros, o crescimento e o amadurecimento das colheitas, a vida e a morte dos homens e animais ${ }^{, 288}$.
}

De fato, a cultura dos povos sempre foi marcada pela realização de festividades. Seja a caminho dos santuários quando em manifestações de alegria coletiva, seja em consagrações,

\footnotetext{
${ }^{285}$ H.-G. GADAMER, WM, I, p. 127.

${ }^{286}$ Id., ibid.

${ }^{287}$ Gadamer reconhece na pesquisa do estudioso húngaro Karl Kerényi sobre a natureza e significado da festa Vom Wesen des Festes, de 1938 - uma grande contribuição para a antropologia e história das religiões. Huizinga, por sua vez, no Homo ludens, publicado no mesmo ano, ressalta uma estreita relação entre a natureza do jogo e a da festa, tendo em vista terem ambos elementos comuns, como alegria, a limitação a um espaço e tempo e a combinação de regras, independência e liberdade.

${ }^{288}$ J. HUIZINGA, Homo ludens, p. 19.
} 
em rituais de sacrifícios, movimentos de danças e disposição de máscaras atemorizantes, banquetes e competições sagradas, todas essas representações significativas constituíram e constituem parte integrante de um grande acontecimento festivo que, por sua vez, altera a ordem da vida cotidiana.

Desse modo, o significado da palavra festa (Fest) refere-se à atitude de celebrar, à ocorrência da comemoração. Ao aparecer em um dado momento, considerado como festivo, a festa conduz seus participantes ao sentimento de um ânimo festivo. Nessa experiência aqueles que dela fazem parte inserem-se em um jogo de comemoração de modo que suas preferências subjetivas e simples opiniões são ultrapassadas. Vive-se a festa enquanto celebração coletiva. Em sua maioria, as festas procedem de um acontecimento original antepassado, entretanto, a atividade de sua celebração não se restringe a ele. A elas pertence o retorno, dirigem-se à repetição. Retorno, porém, não no sentido de uma reminiscência de uma comemoração originária, mas constituindo-se como uma celebração, cuja experiência instaura uma temporalidade sui generis, um presente sui generis. Os momentos festivos são momentos de comemoração, de recordação e também de expectativa, de modo que só há festa mediante sua celebração. Como diz Grondin: "Uma festa - como qualquer obra de arte, mais ainda como qualquer compreender - tem sua existência em seu momento passado e na companhia por meio dos quais se celebra"289.

Diante dessas considerações, Gadamer indaga-se pelo significado de experiência temporal inerente à própria experiência festiva. Do ponto de vista histórico-temporal, o que significa comemorar uma festa? É notório sob o testemunho dos povos que cada comemoração festiva, ao mesmo tempo em que é um retorno, também é um acréscimo de mudanças. Uma mesma festa sofre mudanças, diferentes modos de festejar na própria seqüência do tempo - "pois sempre algo diverso é simultâneo com ela" ${ }^{290}$. A festa de Natal, por exemplo, por mais que remeta ao acontecimento original do nascimento de Cristo, não significa enquanto festividade apenas o retorno de algo que aconteceu há mais de dois mil anos; sua comemoração essencialmente significa a festa que celebramos neste presente; essa presença festiva que nos determina a todos, acompanhada de suas diferenças e atualizações. É seu presente que nos determina festivamente de modo que nos sintamos unidos sempre na circunstância de sua comemoração.

\footnotetext{
${ }^{289}$ J. GRONDIN, Introducción a Gadamer, p. 79.

${ }^{290}$ H.-G. GADAMER, $W M$, I, p. 128.
} 
Ao analisar o caráter temporal da festa, Gadamer adverte que as correlações históricas, ou mesmo a sua relação com sua origem, não determinam sua natureza. Ora, como a festividade só existe uma vez que é comemorada, isso significa que, embora ela tenha sua origem em um dado histórico, sua natureza implica sua regular comemoração; ainda que sempre diferente comemora-se a mesma festa. Num sentido bem radical, diz Gadamer, um ente é temporal na medida em que é sempre diferente. "Este caráter temporal não é concebível a partir da experiência habitual do tempo como sucessão. As dimensões do tempo e a experiência que deles temos somente permitem compreender o retorno da festa como histórico. Uma e a mesma coisa se transforma a cada vez. Na verdade, uma festa não é na realidade a mesma coisa; o é, na medida em que sempre é diferente" ${ }^{291}$. Embora a celebração de uma festa seja uma característica específica de nosso comportamento, a natureza de seu ser não corresponde à subjetividade daqueles que a comemoram. A peculiaridade do tempo festivo faz com que nenhuma festa seja igual a uma outra, mesmo quando na comemoração incessante de seus sucessivos retornos. A festa está aí, chegou seu dia e nela nos inserimos tomando parte. Em sua essencial natureza, sua celebração não reivindica o dispor de um tempo, ou mesmo o preenchimento abstrato do tempo. Bem pelo contrário, em sua representação temporal fundem-se os horizontes de passado e presente, de modo que o caráter de seu retorno implica, concomitantemente, uma referência absoluta a um presente sui generis.

A estrutura de sua temporalidade não pode ser compreendida mediante a experiência normal pragmática em que o tempo é tomado para alguma coisa e como um vazio a ser preenchido. Nesse sentido constituir-se-ia um ritmo de monotonia, um vazio de atividade que necessita ser passado e preenchido. Bem pelo contrário, o tempo só é experienciado enquanto tempo se for tomado em sua plenitude. Eis o que caracteriza a festa. Chegado o tempo da festa, este se torna festivo, preenchido pelo tempo próprio de sua comemoração. É o tempo de seu festejar, de sua demora, cuja natureza está desprovida de caráter calculativo. Como diz Gadamer, assemelha-se ao tempo referente às fases do desenvolvimento humano: a infância, a juventude e a maturidade, em que o que prevalece não é simplesmente uma cronologia de sucessão temporal, o tempo cronometrado pelo relógio ${ }^{292}$. Subitamente, percebe-se que alguém deixa de ser criança e torna-se mais amadurecido ou velho. Trata-se de um tempo cuja

\footnotetext{
${ }^{291}$ Id., ibid., p. 129.

${ }^{292}$ Referindo-se ao tempo no caráter de sua mensuração, diz-nos Heidegger: "Um relógio indica o tempo. Um relógio é um sistema físico, junto ao qual os sucessivos estados temporais idênticos constantemente são ritmados sob o pressuposto de que esse sistema físico não está submetido à mudança pela influência externa" (M. HEIDEGGER, "O conceito de tempo").
} 
totalidade não pode ser compreendida como uma sucessão contínua de momentos vazios. $\mathrm{O}$ tempo da festa é, pois, um tempo de permanência; uma celebração que, por sua vez, convidanos a demorar e preenche-nos, seja nos remetendo ao passado, seja nos inserindo no presente diferenciado e sui generis dos festejos atuais. "A festa [...], pela sua própria festividade, dá o tempo e com sua festividade faz parar o tempo e leva-o a demorar-se - isso é o festejar" ${ }^{\text {"293. }}$.

Ora, qual a relação da estrutura temporal da festa com o fenômeno artístico? O que justifica que numa análise sobre a relação sobre arte e história tome-se como elemento de reflexão a arte enquanto experiência festiva? Gadamer observa nas características da festividade muitas semelhanças com a experiência da obra de arte. $\mathrm{O}$ tempo próprio da arte corresponde ao tempo próprio da festa, sobretudo porque a festa não permite isolamento, é um reunir-se, é um congregar-se. Desse modo, o festejar constitui-se de modos de representação, envolve costumes, hábitos, diferentes expressões de discursos e também manifestações solenes de silêncio. Enquanto atividade intencional, ao celebrarmos, reunimo-nos não sob a forma limitada de estarmos fisicamente uns juntos dos outros, mas na de um estar unido de modo que se toma parte de algo (Dabeisein).

Para melhor explicitar a passagem desse tipo de experiência temporal da vida, específico da festividade, para a experiência artística, Gadamer reporta-se à concepção orgânica da vida, sustentando que a realidade da obra arte assemelha-se a um organismo vivo. Afirmá-la como unidade orgânica significa que cada particularidade sua enquanto um momento a ser contemplado está unida ao todo, cujo efeito é centralizado em sua própria vivacidade $^{294}$. O caráter orgânico da obra de arte, por um lado, assegura a possibilidade de suas mudanças, mediante suas variações, e, por outro, assegura a ela sua específica temporalidade. Afirma Gadamer: "[...] isso não quer dizer que a obra tenha sua juventude, sua maturidade e sua velhice, como o organismo real, vivo, mas quer dizer que a obra de arte, do mesmo modo, não é determinada por uma duração calculável [...] mas por sua própria estrutura temporal”295. Para efeito de ilustração, Gadamer sugere que pensemos na arte musical e no tempo a ser tomado corretamente mediante os acenos e andamentos orientadores

\footnotetext{
${ }^{293}$ H.-G. GADAMER, Aksch., p. 133.

${ }^{294}$ Ao explicar o caráter orgânico da obra de arte, Gadamer reporta-se ao princípio de centralização em si mesmo, característico de um organismo vivo e que estabelece sua própria autoconservação e vivacidade. A esse propósito o filósofo lembra duas formulações anteriores. Inicialmente, a expressão kantiana denominada "conveniência sem objetivo", específica tanto do organismo quanto da obra de arte, e posteriormente, a definição aristotélica sobre o belo artístico que afirma o belo como uma espécie de justo meio ao qual nada pode ser suprimido ou mesmo acrescentado. $\mathrm{O}$ que aqui parece fundamental é que seja assegurada a unidade viva que se estrutura em si mesma e tem seu tempo próprio (cf. H.-G. GADAMER, Aksch, p. 134).

${ }^{295}$ Id., ibid.
} 
do compositor, referentes à execução de sua peça. De modo enfático, então, sustenta o hermeneuta, constitui-se uma atitude enganosa buscar uma padronização canônica em nome de uma autêntica tomada de compositor. Em vez disso, é necessário deixar-se fazer valer a criatividade, de modo que se procure o tempo próprio, seja de uma peça musical, de um texto poético ou mesmo de uma encenação teatral. Afinal, "só se transmite uma real experiência artística da própria obra, quando nós, com nosso ouvido interior, ouvimos algo completamente diverso do que se passa realmente diante de nossos sentidos" ${ }^{\prime 296}$.

Da mesma forma, isso também se dá com a experiência do ritmo. Ouvir uma seqüência de sons que se repetem significa também ritmizar essa mesma seqüência. Desse modo, a atividade de ouvir um ritmo implica ritmizarmos nós mesmos, seja pelo movimento corporal da dança ou apenas dos dedos e das mãos, ou mesmo do cantar, como se o estivéssemos reproduzindo dentro de nós. Afinal, "somente porque somos ativos no transcender dos aspectos contingentes é que surge o produto final ideal" ${ }^{\text {"297 }}$. As artes, sejam aquelas de caráter mais transitório, a arte da linguagem ou as artes plásticas, quaisquer que sejam, são sempre constituídas por um tempo próprio que, por sua vez se impõe a nós. Diante de uma tela ou de uma construção arquitetônica passeamos, lemos, construímos. O tempo que nos permite acesso a estas representações, os "passos-do-tempo", é ora mais rápido, ora mais lento, de modo que nos possibilita junto a elas uma relação não de monotonia, mas de demora. Demorarmo-nos na obra de arte constitui-se, portanto, um exercício de aprendizagem necessário para uma apreensão mais rica e diversa da experiência artística. Para Gadamer, a atitude de determo-nos na obra, além de corresponder à essência do caráter temporal da arte, também exprime a medida de nossa finitude num horizonte de eternidade.

Assim como a festa só é para quem participa dela, ou seja, para aquele que se predispõe à peculiaridade da presença comemorativa, da mesma forma, diante de uma obra de arte a condição de espectador implica a existência de alguém que toma parte (Dabeisein), integrando sua experiência temporal e assim determinando seu ser. Tomar parte não como justaposição de uma simples presença, mas como efetiva participação. Daí que aquele que realmente assiste engendra uma forma de participação no sentido mesmo de comunhão sacral revelado pela expressão grega theori ${ }^{298}$. O espectador que participa e entrega-se, prendendo-

\footnotetext{
${ }^{296}$ Id., ibid.

${ }^{297}$ Id., ibid., p. 135.

${ }^{298}$ Lembra Gadamer que, de acordo com a designação desse termo grego, theoros corresponde àquele que participa de uma delegação de festa. Sua atribuição limita-se à singularidade de seu fazer-se presente. É espectador porque toma parte, assiste enquanto participa da experiência festiva. Tendo em vista a compreensão da metafísica grega, a natureza da theoria significa também tomar parte no verdadeiro.
} 
se ao jogo da arte, reivindica ${ }^{299}$ uma demora no sentido de permanência e duração; um tomar parte sob a forma daquilo que outrora acenamos como simultaneidade (Gleichzeitigkeit). A temporalidade festiva da obra de arte caracteriza-se por sua "simultaneidade". Eis outro aspecto inerente ao ser da obra de arte. Convém ressaltar que, na reflexão hermenêutica aqui presente, não se trata de uma simultaneidade enquanto um ser-ao-mesmo-tempo de vivências da consciência, mas significa a atualização de algo individual. Reportando-se Gadamer à significação teológica atribuída por Kierkegaard, "simultâneo" implica a tarefa de "intermediar entre si aquilo que não é ao-mesmo-tempo, como a própria presença e salvação de Cristo, de tal maneira pleno, que elas, apesar de tudo, possam ser experimentadas e levadas a sério como algo presente ${ }^{\$ 300}$. Trata-se de um tomar parte enquanto genuína participação no acontecimento, de uma intermediação que não pode de forma alguma ser descartada na compreensão hermenêutica da experiência artística.

Sendo a "simultaneidade" o caráter essencial da experiência temporal da arte, o processo de intermediação do espectador determina-se como imprescindível para compreender a estrutura do ser estético. Também nesse sentido Gadamer identifica na "Tragédia" um exemplo paradigmático cuja retomada de sentido, além de constituir-se como demonstração crítica à noção de "consciência estética", recupera a própria significação sacral da obra de arte. Na representação da tragédia reside o exemplo mais destacado da simultaneidade da arte. Para além de uma forma estética de arte, o fenômeno do trágico ultrapassa os limites da obra de arte trágica, e revela a vida humana. Além do âmbito puramente estético, o trágico também se constitui fundamentalmente como fenômeno metafísico-moral ${ }^{301}$. Uma vez representada, a tragédia remete-se sempre à tragédia da vida.

\footnotetext{
${ }^{299}$ Empenhando-se em elucidar a natureza do espectador como mais um elemento indicativo do caráter temporal da experiência da arte, Gadamer aprofunda o significado do tomar parte proveniente do espectador. Tomar parte no sentido da possibilidade positiva de estar-fora de si (Außersichsein), perfazendo a natureza do seu entregar-se, do entregar-se a uma visão (Anblick). Tal manifestação não implica, todavia, um estado privativo, nem tampouco se restringe a um momento de encantamento; bem além dessas designações, ela sustenta uma reivindicação. Reivindicação que busca fazer-se valer na concretização de sua própria exigência. Segundo Gadamer, esses esclarecimentos foram desenvolvidos pela reflexão teológica de Kierkegaard mediante a explicação do conceito de "simultaneidade" (cf. H.-G. GADAMER, WM, I, p. 130-1).

300 H.-G. GADAMER, WM, I, p. 132. Gadamer orienta-se pela compreensão kierkegaardiana de "simultaneidade". "A simultaneidade significava para ele o incitar da mensagem cristã que chega a todos e a cada um. Nele não se trata de uma história que se desenvolveu há dois mil anos e que temos de apreender com a devida distância, mas sim que se trata de um chamado ao qual nada pode subtrair-se. Cada um se sente interpelado por ela e chamado a adotar uma decisão. Antes de Gadamer esse motivo tinha-se renovado na teologia dialética de Karl Barth e Rudolf Bultmann. Ambos se referiram a essa 'simultaneidade', a fim de manter em seus devidos limites o historicismo da teologia liberal" (J. GRONDIN, Introducción a Gadamer, p. 81).

${ }^{301}$ Essa concepção de tomar o trágico enquanto momento extra-estético foi anteriormente desenvolvida por Richard Hamann em sua Ästhetik e Max Scheler em Vom Umsturz der Werte, Zum Phänomen des Tragischen. Mas, além dessas reflexões, o que parece aqui ser determinante é a própria concepção de não distinção estética
} 
Se pensarmos no espetáculo teatral grego, temos que nem o artista criador, nem o ator, aquele que representa, nem o espectador que contempla e acolhe o espetáculo possui, em relação ao ser da obra de arte, uma legitimação própria e exclusiva. O que se faz representar é de tal forma dotado de um núcleo de sentido, que não permite dispersões para outro horizonte de realidade. $\mathrm{O}$ remeter-se do espectador a um distanciamento - distância para o olhar -, ao mesmo tempo em que o conduz ao seu auto-esquecimento, também o insere em sua continuidade consigo mesmo. Essa entrega justifica-se porque diante de si o que se representa é a verdade ética e religiosa de seu próprio mundo, no qual se reconhece. O modo de ser do estético presentifica o próprio absoluto, o momento em que o auto-esquecimento do espectador converte-se em intermediação consigo mesmo.

Dessa forma parece justificar-se por que o distanciamento do espectador pertencendo à essência do trágico, constitui um momento essencial do chamado momento estético. Nas palavras de Gadamer: "O espectador não se comporta com a distância com que a consciência estética desfruta da arte da representação, mas sim como comunhão do tomar parte. Em última instância, o genuíno centro de gravidade do fenômeno trágico está naquilo que se representa e se reconhece e no qual, obviamente, a participação não pode ser aleatória" ${ }^{302}$. A encenação do espetáculo trágico, ao representar uma situação de vida, de modo algum toma o espectador num sentimento de perplexidade, pois a comoção manifestada por este revela sua própria continuidade de vida, sua continuidade consigo mesmo. É seu mundo que vem a seu encontro sem que possa ser suprimido ou diferenciado esteticamente. Esse caráter de autoencontro suscitado pelo fenômeno trágico, Gadamer o identifica em todas as demais artes.

Como ressaltamos anteriormente, o exemplo do trágico desenvolvido por Gadamer ainda se põe como uma extensão crítica à própria noção de "consciência estética". Isso se torna bastante claro em sua retomada da leitura feita por Aristóteles do conceito de "Tragédia". Na Poética a essência da tragédia define-se em função de seu efeito específico sobre o espectador. Sua ação efetua uma katarsis, uma purificação das paixões de eleos e phobos. Ambas as paixões, se, por um lado, indicam um tomar-se de surpresa, por outro, são também ocorrências capazes de arrastar os seres humanos consigo mesmos. Eleos, a compaixão, a aflição, corresponde ao estado de desolação (Jammer); tanto o sentimento interior quanto a abertura expressa de seu lamento. Phobos significa o temor, ou mesmo o espanto de tremor que acomete um sujeito a caminhar para sua própria ruína e que por isso

como uma resultante de sua crítica à consciência estética. Eis o que justifica a atribuição da tragédia como uma função exemplar.

${ }^{302}$ H.-G. GADAMER, WM, I, p. 137. 
também nos faz tremer. Portanto, é essa circunstância do efeito causado aos espectadores, mediante a qual estes experimentam a purificação de seus afetos, o que representa a natureza da tragédia.

O que a torna paradigmática enquanto um fenômeno estético fundamental é, em primeiro lugar, seu modo de apresentação dramática constituir-se como representação, jogo (Spiel), transformação em configuração (Gebilde). Além disso, o modo pelo qual era encenada entre os gregos, o fato de integrar o espectador sob a forma de uma celebração festiva, radicalmente inseparável do caráter trágico da vida.

Ao tomarmos a categoria da "festa" como elemento de análise para o caráter temporal da arte, é necessário considerarmos sua íntima relação com as demais categorias inerentes à particularidade de seu modo de ser, quais sejam, o "jogo" e o "símbolo". Nesse sentido tomar a experiência da arte como experiência hermenêtica significa ultrapassar o esquema reflexivo e essencialmente subjetivo da consciência estética, reivindicando-a como um horizonte histórico de representação, mediante o qual o homem se reconhece. Se a compreensão de sua presença incita-nos a um diálogo com a tradição, o específico de sua temporalidade constitui-se em "ter o seu ser no ser representado, [...] existente no caso da reprodução como um fenômeno independente e elevado" ${ }^{\text {"303 }}$ Uma festa, assim como uma obra de arte ou mesmo o fenômeno do compreender, reivindica, no caráter hermenêutico de sua historicidade, um horizonte de existência que tem seu tempo passado, bem como a companhia por meio da qual se celebra. Por isso, a arte sensibiliza-nos para a recuperação da verdade, e isso se dá enquanto movimento de continuidade de nossa própria existência por meio do qual celebramos a experiência de nossa própria finitude e temporalidade.

Desse modo, a experiência da arte a ser tomada sob o critério da vigilância da história dos efeitos remete-nos a uma outra dimensão, pela qual determina sua atualização temporal. Uma vez que sua compreensão só se realiza por intermédio de uma lógica de mediação entre o presente e a tradição, a fusão de horizontes que daí decorre envia-nos ao específico desempenho da linguagem; o horizonte hermenêutico, além de histórico, encerra em si o caráter da conversação e se põe como linguagem. Ainda no sentido de ratificar o caráter de importância do princípio de Wirkungsgeschichte para a compreensão hermenêutica da arte, ressalte-se o seguinte: uma vez que a realização produtiva da compreensão hermenêutica é essencialmente motivada pela autoridade significativa da tradição, essa não se converte em

$\overline{{ }^{303} \text { H.-G. GADAMER, WM, I, p. } 139 .}$ 
um horizonte a ser dominado, posto que constitui-se como "linguagem transmitida, na qual vivemos" 304

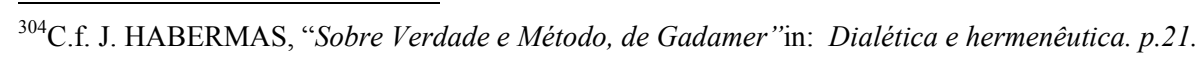




\section{ARTE E LINGUAGEM: UMA RELAÇÃO HERMENÊUTICA}

\subsection{A arte sob a primazia da linguagem (Sprach): Aproximações}

O que torna específica a reflexão de Gadamer sobre a hermenêutica filosófica é também o caráter de sua virada ontológica por meio do fio condutor da linguagem. Nesse sentido e dando-se continuidade à análise desenvolvida sobre o fenômeno da arte à luz da compreensão da experiência hermenêutica, nosso propósito aqui é examinar em que medida a linguagem constitui-se como fundamento de análise para a reivindicação de verdade a partir da arte. Mediante o itinerário até então desenvolvido, a passagem da crítica da consciência estética à noção de consciência histórico-efeitual mostrou-nos que a experiência da arte enquanto uma experiência de finitude histórica traz em sua presença o horizonte de uma mediação lingüística. A análise ontológico-hermenêutica sobre o fenômeno da arte, que tem como ponto de partida um pensar radical sobre seu modo de ser, culmina também em uma reflexão sobre o fenômeno da linguagem (Sprach).

Já em Estética e hermenêutica (Ästhetik und Hermeneutik) aquilo que perfaz a possibilidade de relação entre estética e hermenêutica tem como ponto de partida a seguinte afirmação: "A obra de arte nos diz algo" ${ }^{\$ 05}$. Disso resulta o fato de esta tornar-se objeto de reflexão hermenêutica. Também por esse motivo radica na reflexão gadameriana o desenvolvimento da questão da linguagem da arte a partir de sua legitimidade hermenêutica enquanto experiência. Ao dizer algo, a obra de arte quer ser compreendida. Essa experiência do dizer, na medida em que ultrapassa um sentido fixo daquilo que pode ser dito e nos remete à expectativa de sentido e do encontro, justifica por si só uma reflexão hermenêutica sobre o fenômeno da arte e, fundamentalmente, sua abordagem como experiência da linguagem.

O que constitui a legitimidade dessa reflexão é, pois, sua análise como fenômeno hermenêutico, estando essencialmente inserida no âmbito significativo do conceito de experiência hermenêutica; formulação na qual a dimensão da linguagem constitui-se num caráter radicalmente definitivo: o medium da experiência hermenêutica.

${ }^{305}$ H.-G. GADAMER, Ästhetik und Hermeneutik, p. 1. 
A força declarativa (Aussagekraft) ${ }^{306}$ da arte a torna uma experiência sempre aberta a novas interpretações (Auslegung), um acontecimento que atravessa o tempo presente sob o testemunho de que sempre há algo a nos dizer. Tais designações, se, por um lado, identificam a peculiaridade de uma reflexão hermenêutica, por outro, viabilizam uma abordagem sobre a íntima relação entre arte e linguagem.

Embora do ponto de vista genérico isso possa nos parecer óbvio, remetendo-nos aos fundamentos da hermenêutica gadameriana, o tratamento dessa relação apresenta suas particularidades. Identificamos, ao longo da estrutura de Verdade e método, não apenas uma simples uma associação, mas uma interdependência entre os três níveis de experiência desenvolvidas: arte, história e linguagem. Cada uma delas constitui-se num nível de explicitação da experiência hermenêutica, de modo que a compreensão total de sua estrutura abrange uma intercambialidade entre o jogo (arte), a consciência histórica (a história dos efeitos - Wirkungsgeschichte) e o diálogo (linguagem).

Como temos no fenômeno hermenêutico da arte nossa referência de análise, a questão que aqui nos orienta é a seguinte: a partir dos fundamentos da hermenêutica filosófica, o que justifica a abordagem da linguagem como condição de legitimidade de uma reflexão hermenêutica sobre a arte como experiência de verdade arte? O que nos acrescenta pensar o caráter declarativo da arte a partir da compreensão hermenêutico-filosófica sobre a linguagem? Vista na perspectiva do fenômeno hermenêutico da arte, a explicitação da linguagem, ainda que num primeiro momento, apresenta-se como um detalhamento de seu caráter de atualidade intemporal, inicialmente exposto em sua abordagem como experiência histórica.

Entendendo-se o caráter declarativo da arte como seu permanente falar, disso não se segue que sejamos sempre meramente conduzidos ao sentido e significado daquilo que se foi, nem tampouco intenciona a determinação de sua permanência. Se sua presença lingüística fala como os resíduos de um passado, não é no sentido de fixar algo estabelecido como recordação. Assim como as demais experiências do mundo, o fenômeno artístico pertence ao âmbito da experiência do mundo que, inexoravelmente, expressa-se lingüisticamente ${ }^{307}$ e

\footnotetext{
${ }^{306}$ Vale lembrar neste momento que o título conferido à coletânea dos textos estéticos reunidos no Vol. 8 de suas Gesammelte Werke é Arte como declaração (Kunst als Aussage). A arte é uma declaração, enfatiza Gadamer.

${ }^{307}$ Nessa questão Gadamer utiliza duas expressões: Sprach (linguagem) e Sprachlichkeit (lingüisticidade). Sobre o uso destas, é de fato perceptível em Verdade e método uma incidência maior do uso da segunda expressão, o que posteriormente conduziria Gadamer a uma melhor explicitação desses termos. Nesse sentido, são pontuais as observações de Grondin: "No Diálogo da Antologia, de 1996, Gadamer expõe mais detalhadamente essa diferença [...] Por lingüisticidade entende unicamente o esforço de nossa finitude encaminhado à linguagem,
} 
revela um sentido. E o grande desafio que essa experiência nos impõe, enquanto experiência de linguagem, é, pois, como compreender o que esta diz a si e aos outros; como compreender seu sentido a partir do confronto dela conosco mesmos. A arte, enquanto experiência hermenêutica, além de declaração (Aussage), é interpretação (Auslegung); eis o que a torna essencialmente um fenômeno lingüístico.

Verificamos, anteriormente, que, além de remeter-nos a uma experiência lúdica, simbólica e comemorativa, o modo de ser da arte enquanto um modo de reivindicação de verdade constitui também uma experiência histórico-efeitual. E, na qualidade de experiência da consciência histórica, sua presença converte-se em uma experiência de linguagem e intermediação, de conversação, de diálogo. Portanto, é a partir do eixo explicativo da concepção gadameriana de linguagem, sobretudo no que concerne à relação compreensãointerpretação, que apontaremos indicadores de uma análise hermenêutica sobre arte e linguagem $^{308}$.

Considerando o itinerário desenvolvido em Verdade e método, a investigação sobre a linguagem como fio condutor da hermenêutica é precedida pela explicitação da idéia de história dos efeitos (Wirkungsgeschichte). No final de sua reflexão sobre a consciência histórico-efeitual, Gadamer adverte-nos de que sua conviç̧ão sobre essa idéia de história de modo algum corresponde a uma ingenuidade metodológica, cujo intento seria a comparação de horizontes e situações históricas. Ao contrário, o que a sustenta advém, fundamentalmente, da predisposição característica da experiência humana, de sua disposição à abertura àquilo que lhe vem ao encontro ${ }^{309}$. Portanto, a compreensão da consciência hermenêutica necessariamente histórica, conforme vimos anteriormente - determinando-se em função do conceito de experiência, seu detalhamento implica uma reflexão sobre a estrutura lógica dessa abertura.

\footnotetext{
quer dizer, a uma compreensão: um esforço que conhece muito bem os limites dos correspondentes enunciados. Pensa-se na virtualidade do entender lingüístico, quer dizer, na possibilidade sempre aberta, embora nem sempre realizada de nossa ação de compreender [...] Assim, uma imagem, uma representação, uma interpretação musical, provoca sempre uma compreensão..." (J. GRONDIN, Introducción a Gadamer, p. 195-6). Portanto, lingüisticidade (Sprachlichkeit) não corresponde em sua significação àquilo que designa o termo lingüística enquanto ciência

${ }^{308}$ Nosso propósito aqui é delimitar o domínio de análise, sobretudo, à obra Verdade e método. De fato, a relação entre arte e linguagem é desenvolvida posteriormente por Gadamer, seja pelas reflexões teóricas ou pelos ensaios sobre peças artísticas. Nestes identificam-se um aprofundamento, detalhamento ou mesmo demonstração de alguns argumentos previamente indicados em Verdade e método.

${ }^{309}$ Cf. H.-G. GADAMER, $W M$, I, p. 367-8.
} 
Assim, o primeiro antecedente para uma análise hermenêutica da linguagem diz respeito ao modo pelo qual a linguagem integra-se à estrutura da obra Verdade e método, ou seja, ao modo pelo qual a experiência hermenêutica determina-se enquanto experiência de abertura. Como se realiza essa experiência? Sua resposta é enfática:

“[...] em toda experiência encontra-se pressuposta a estrutura da pergunta. Não se fazem experiências sem a atividade do perguntar. O conhecimento de que algo é assim, e não como acreditávamos primeiramente pressupõe evidentemente a passagem pela pergunta se de fato algo é assim ou de outro modo. A abertura que está na essência da experiência é, logicamente falando, esta abertura do 'assim ou de outro modo'. Tem a estrutura da pergunta",310.

Compreender é, pois, inserir-se no horizonte do perguntar para além daquilo que está sendo dito. Ademais, o significado de uma hermenêutica da aplicação - hermenêutica filosófica - obedece ainda àquilo que Gadamer se refere como sendo "lógica da pergunta e da resposta" ${ }^{311}$, ou mesmo dialética da pergunta e da resposta, inerente à estrutura da experiência hermenêutica. É ela, na verdade, que melhor determina a especificidade da consciência histórico-efeitual. Cada compreensão decorre de termos aplicado algo em nós, de modo que descubramos respostas a partir de interrogações. Perguntas que foram assumidas em uma tradição e que determinam nossa compreensão. Assim, o que confere a um texto sua possibilidade falante são as motivações de um perguntar, nossas interrogações e expectativas repletas de sentido dirigidas a ele em busca de respostas. Desse modo, a compreensão especifica-se e realiza-se como uma relação de conversação (Gespräches), "pois a dialética da pergunta e da resposta [...] permite que a relação da compreensão manifeste-se como uma relação recíproca, semelhante à de uma conversação. É verdade que um texto não nos fala como faria um tu. Somos nós, os que o compreendemos, os que temos de trazê-lo à fala, a partir de nós" $\$ 12$.

\footnotetext{
${ }^{310}$ Id., ibid., p. 368.

311 Essa "lógica da pergunta e da resposta", que por sua vez ressalta a primazia do perguntar, tem como fundamento o modelo dialético platônico. A dialética platônica é assumida como modelo hermenêutico, constituindo-se, portanto, em caminho necessário do movimento circular da compreensão. Se a explicitação da experiência hermenêutica toma a dialética hegeliana exposta na Fenomenologia do espirito como pressuposto necessário, é remetendo-nos, em seguida, à dialética platônica que a referência à pergunta, no caráter de sua primazia, afirma-se como modelo da experiência hermenêutica. "De fato, é a doutrina da anamnesis que exprime o sentido verdadeiro da pergunta socrática, e Platão, ao apresentar Sócrates como mestre da recordação, impede esquecer-se de que saber é reminiscência [...] com base no saber prévio de que pela linguagem todo homem apropria-se, saber o que não se sabe não é simplesmente ignorância, mas implica um pré-saber, que conduz com toda busca ou pergunta. [...] A estrutura da anamnesis tem a extensão da possibilidade de perguntar, e, por isso, perguntar sob a condução do procurado, isto é, só podemos compreender o que de algum modo já encontramos previamente. [..] quem pergunta é sempre ao mesmo tempo interrogado. A pergunta é a voz direta da finitude humana" (M. PEREIRA, "O século da hermenêutica filosófica").

${ }^{312}$ H.-G. GADAMER, $W M$, I, p. 383.
} 
Ora, isso também significa que o próprio desenvolvimento da consciência históricaefeitual, ao se concretizar como compreensão dialética de pergunta e resposta e aplicar um sentido a nossa situação, corresponde a um contínuo processo de conversação iniciado antes mesmo de nós. A história dos efeitos, como afirma Gadamer, é mais ser do que propriamente consciência ${ }^{313}$; também por isso pertencemos muito mais a ela do que ela a nós. Apenas damos continuidade a essa conversação mediante as expectativas de sentido que, historicamente, exprimem a facticidade de nossa situação de estar-no-mundo e a profundidade de nossa finitude.

A compreensão de diálogo hermenêutico em Gadamer retoma o significado da reflexão feita por Collingwood quando este desenvolve a idéia de uma "logic of question and answer", e então argumenta nosso autor: "Somente se pode compreender um texto quando se compreendeu a pergunta para a qual ele é a resposta [...] a pergunta somente se ganha a partir do próprio texto, e a adequação da resposta representa o pressuposto metódico para a reconstrução da pergunta ${ }^{\text {"314 }}$. O que deve orientar todo e qualquer conhecimento histórico é a advertência que consiste em conhecer a pergunta e a resposta inerentes à tessitura de um texto. Do ponto de vista de sua essência, o ato de perguntar corresponde a uma indagação de sentido, mediante a qual o interrogado é submetido a uma perspectiva determinada, podendo sua resposta ser adequada ou não. Assim sendo, no que se refere, por exemplo, à compreensão da arte, esta só se torna possível na medida em que se pressupõe sua adequação, ou seja, desde que identifiquemos qual a pergunta para a qual ela se apresenta como resposta.

O que confere à experiência hermenêutica sua verdadeira dimensão é, pois, a estreita relação entre perguntar e compreender. Aquele que pergunta está movido pelo impulso de resistência ao acolhimento de opiniões preestabelecidas, pois é essa predisposição indagativa que se constitui naquilo que move o ser humano a fazer experiências. O perguntar, como assinala Gadamer, é muito mais um padecer; é um "pôr em suspenso" (In-die-Schweb) ${ }^{315}$ as possibilidades de verdade, em benefício da inquietude e do questionamento. Um verdadeiro compreender só se torna possível na medida em que nos inserimos no verdadeiro perguntar; distanciamo-nos das reproduções de alheias opiniões e prosseguimos pondo à prova e mantendo abertas as diferentes possibilidades de sentido ${ }^{316}$. Eis por que a atividade do pensar

\footnotetext{
${ }^{313}$ C.f. Rhetorik, hermeneutik und Ideologiekritik., in: H.-G. GADAMER, WM, II, p. 247.

${ }^{314}$ Id., ibid., p. 376.

${ }^{315}$ Cf. H.-G. GADAMER, $W M$, I, p. 380.

${ }^{316}$ Retomando a consideração da compreensão como um introduzir-se na tradição, para Gadamer esta sempre se constitui como continuação de uma conversação já iniciada. Continuamos essa conversação na medida em que nos deixamos orientar por novas perspectivas de sentido. Por isso, a compreensão é aplicação, exercício dialético
} 
implica, necessariamente, a permanência deste procedimento: sempre perguntar. A experiência hermenêutica realiza-se, portanto, mediante sua essencial abertura expressa pela dialética da pergunta e da resposta. É só por meio dessa relação que a compreensão torna-se possível como uma relação recíproca, de modo que compreender algo é trazê-lo à fala, a partir de nós mesmos.

A fusão de horizontes, mediante a qual somos interpelados e intermediados ao passado, encontra nessa lógica do perguntar sua realização específica, uma vez que, buscando as respostas latentes na tradição, acrescenta ao fenômeno da compreensão o universo necessário de sua realização e abrangência. É, pois, nesse sentido que a compreensão seja de um enunciado, de uma ação ou mesmo de um texto ou de uma obra de arte se dá pelo experiência da linguagem. A fusão de horizontes é, essencialmente, lingüística e dessa forma nos insere num processo dialógico. Concebendo-se o compreender como aplicação, segue-se que esse movimento só acontece quando entendemos a esfera de sentido que determina o que se há de interpretar. Nesse propósito, compreendê-lo é manifestar-se, seja por palavras ou outras expressões; é inserir-se no fenômeno hermenêutico primordial da linguagem como resposta a uma pergunta.

$\mathrm{Na}$ verdade, o que conduz Gadamer a uma investigação acerca da linguagem é um duplo reconhecimento: de um lado, o caráter obscuro de sua reflexão ${ }^{317}$; por outro, o caráter de conversação, horizonte no qual estamos necessariamente inseridos enquanto seres de compreensão hermenêutica. O que lhe confere obscuridade é sua extrema proximidade ao pensar, bem como essa inquietude que perfaz sua íntima relação com o ser. Dela só podemos aproximar-nos porque nela habitamos e vivemos.

Inevitavelmente é sob a forma de linguagem que se torna possível a compreensão, independentemente da diversidade das situações. É ela que sempre se impõe, seja quando na relação entre um intérprete e seu texto, seja simplesmente se referindo à conversação entre dois interlocutores na tentativa de um acordo. Eis o âmbito no qual a compreensão realiza-se: a linguagem na qual algo vem à fala, não como um ajuste de ferramentas ou como um simples revestimento de palavras e expressões, mas como uma conversação que se estabelece e reúne

da pergunta e da resposta. Sobre isso, escreve Grondin: "Entender um texto do passado significa traduzi-lo para nossa situação presente, escutando nele uma discursiva resposta para os questionamentos de nossa era. Foi uma aberração do historicismo tornar a objetividade dependente da extinção do sujeito interpretante, porque a verdade, aqui concebida como abertura de sentido [aletheia], ocorre apenas no decurso da aplicação históricoefetiva" (J. GRONDIN, Introdução à hermenêutica filosófica, p. 194).

317 A linguagem, diz o hermeneuta, "[...] é uma das coisas mais obscuras que há para a reflexão. O caráter lingüístico [Sprachlichkeit] está tão extraordinariamente próximo de nosso pensar e em sua realização é tão pouco objetivo, que ele esconde, a partir de si mesmo, seu verdadeiro ser" (H.-G. GADAMER, WM, I, p. 555). 
os interlocutores em uma nova comunidade e cujo acordo põe-se como uma "transformação rumo ao comum, de onde já não se continua sendo o que se era”318.

A terceira parte de Verdade e método mostra, especificamente, que a virada realizada pela hermenêtica mediante a consideração de seu caráter ontológico ${ }^{319}$ efetiva-se na linguagem; esse fio condutor no qual e somente a partir do qual o sentido do ser vem à fala e pode ser tomado como experiência hermenêutica. Constitui-se no medium da experiência hermenêutica porque é enquanto um processo de conversação que a experiência revela-se em sua própria verdade, deixando aparecer aquilo que é, possibilitando a realização do acordo e o entendimento sobre as coisas. A linguagem emerge como horizonte radical da ontologia hermenêutica pelo fato de que, enquanto sentido, o ser só pode se dar sob a forma de linguagem. Daí a paradigmática formulação de Gadamer: "O ser que pode ser compreendido é linguagem, ${ }^{320}$.

Essa intuição de pensar a linguagem a partir do ser, ou mesmo a compreensão do ser enquanto linguagem, remete-nos à reflexão heideggeriana sobre a linguagem. No entanto, embora seja decisiva para a hermenêutica filosófica, a referência a esses escritos não aparece de forma direta em nenhum momento da obra Verdade e método. Convém lembrar, nesse sentido, que a obra de Heidegger Caminhos para linguagem (Unterwegs zur Sprache) surgiu apenas em 1959, momento em que Verdade e método já se encontrava em fase de impressão. É bastante óbvio, todavia, que Gadamer conhecia as reflexões heideggerianas sobre linguagem e poesia, e que devem tê-lo inspirado.

Em Heidegger, o tratamento da linguagem tem como horizonte investigativo seu modo de ser, logo, esta só pode ser pensada a partir da constituição ontológica do Dasein. Sua reflexão não a prioriza enquanto expressão de um conjunto de proposições, um acervo de categorias semânticas sob uma eterna rede de significados, mas enraíza-se na atividade humana, junto à compreensão do Dasein como ser-no-mundo. Abordá-la, portanto, é inserirse em seu caráter existencial ontológico, em vista do qual ela está articulada à fala $(\text { Rede })^{321}$.

\footnotetext{
${ }^{318}$ Id., ibid., p. 384.

${ }^{319}$ A reflexão que faz da ontologia uma ontologia hermenêutica, descaracterizando-a como uma construção da totalidade do mundo dos entes e assegurando-a como experiência histórica e interpretação dessa experiência, foi conduzida por Heidegger. Por conseguinte, a pergunta da ontologia dirige-se, então, ao sentido do ser, de modo que só a partir do "Ser enquanto sentido" é que se pode determinar o que seja real. É precisamente essa busca de sentido do ser que torna possível a práxis histórica dos seres humanos. Essa compreensão é determinante para a concepção da linguagem enquanto mediação da experiência hermenêutica.

${ }^{320}$ H.-G. GADAMER, $W M$, I, p. 450.

321 "Rede", originalmente "explicação, razão, etc.", correspondendo ao latim ratio, agora significa "fala, discurso, palavras, conversação, etc.” Esse termo deu origem a reden, "falar etc.”, Sprache, "discurso, linguagem
} 
Essa formulação está expressa em Ser e tempo (Sein und Zeit), no § 34, embora não possamos reduzir a esse parágrafo o lugar que ocupa a reflexão sobre a linguagem nesta obra.

Afirma Heidegger: "[...] a linguagem deve indicar que este fenômeno radica-se na constituição existencial da abertura do Dasein. O fundamento ontológico existencial da abertura é a fala". Falar aqui não corresponde ao desempenho de uma atividade do espírito humano, não é o produto de uma atividade falante, mas um momento estrutural do Dasein, um elemento constitutivo de seu existir, cuja abertura a regula. Pensar a linguagem em sua relação com o ser significa aqui pensar o ser essencialmente ligado ao logos. Mas também, subordinado à linguagem, o homem, ao poder falar, predispõe-se à condição de ouvinte e à escuta do silêncio. Enquanto um ser que vive e existe (existentia), sua relação com a linguagem não é a de quem possui uma faculdade entre outras, mas de quem a habita como morada. Ao contrário, a linguagem é a casa do ser: nela o homem, morando, ec-siste enquanto pertence à verdade do ser, protegendo-a”,322. A esse propósito, conforme observa Gadamer, habitar não significa estar diante dos objetos, mesmo no intuito de dominá-los. "Habitamos no habitual. Isto também é a linguagem, algo dentro do qual se vive e habita, e donde se está em casa $^{, 323}$.

Assim, a linguagem desempenha a função de elemento originário do estado de lançarse, projetar-se, a partir do qual nós, enquanto aí ( $d a$ ), estamos abertos ao mundo. Ela perfaz a condição ontológica de possibilidade do Dasein: compreender, interpretar, desvelar sentido, o que se viabiliza junto ao ser da palavra e da linguagem. Compreender-se como ser-no-mundo é pronunciar-se sob a forma de um vir-à-fala; é interpretação enquanto articulação de sentido, é comunicação enquanto partilha. Ainda que mediante essa concepção a linguagem não seja contemplada enquanto repertório categórico de significações, isso, porém, não significa que os enunciados devam ser desconsiderados e eliminados. Trata-se de fazer sobressair a estrutura prévia, explicativa ou interpretativa, que possibilita o acesso aos entes ${ }^{324}$.

Retomando a afirmação gadameriana que articula o ser, a compreensão e a linguagem, em sua densidade, parece que estamos diante do agir da própria coisa enquanto um movimento especulativo que assegura ao falante a expressão do próprio falar no sujeito. Essa ação é da própria estrutura ontológica universal, radicalmente constituidora de tudo. O agir é

etc." "[...] Rede é a fala informal em um contexto particular. Rede não precisa conter uma sentença gramatical” (M. INWOOD, Dicionário Heidegger, p. 64-5).

${ }^{322}$ M. HEIDEGGER, Sobre o humanismo, p. 159.

${ }^{323}$ H.-G. GADAMER, "Heidegger y el lenguaje", in: Los caminos de Heidegger, p. 321.

${ }^{324}$ Cf. T.A.-Á. Bay, El lenguaje en el primer Heidegger, p. 148-50. 
do próprio ser, e nele se funda toda a linguagem universal da hermenêutica e das interpretações concretas que se determinam. É precisamente a partir dessa compreensão que se torna possível mencionarmos uma linguagem da natureza, uma linguagem da arte, uma linguagem das coisas. Por isso, a estrutura especulativa da linguagem tem seu fundamento em uma dimensão ontológica. Chegar à linguagem, aproximar-se dela é permitir-lhe apresentar-se como ser que exige. O ser é linguagem porque é apresentação de si mesmo. Portanto, é só a partir da constituição ontológica de todas as coisas que a experiência hermenêutica do ser enquanto abertura e compreensão revela-se como experiência hermenêutica da linguagem.

Assim, do princípio básico de equivalência entre a compreensão e a interpretação, mediante o qual a interpretação sempre se realiza de acordo com uma apreensão lingüística (Sprachlichkeit) da realidade, emerge o caráter universal da própria linguagem. E o que perfaz essa universalidade é a própria universalidade da razão. Seu caráter de infinitude assim também pode ser traduzido: “A linguagem é a linguagem da própria razão"325. Ora, como pensar esse tipo de proximidade entre a linguagem e a razão? O que justifica mencionar a linguagem como determinação universal da razão?

Com a linguagem, considerando-se a diversidade das línguas, nomeamos as coisas e convencionamos as palavras; expressões essas que, às vezes, em sua originalidade parecem ser únicas e inseparáveis dos conteúdos que designam. Daí que a tradução, tendo em vista essa íntima unidade entre a palavra e a coisa, muitas das vezes, não passa de um rodeio interpretativo apenas capaz de circunscrever um texto, em vez do que seria propriamente traduzi-lo. Se, todavia, vivemos na linguagem atados por uma língua, como compreendermos o caráter estranho de uma tradição? Segundo Gadamer, é a sensibilidade de nossa consciência histórica que determina esse esforço para interpretar e compreender fatos e acontecimentos que vêm de longe. É a razão pensante, enquanto experiência e linguagem - razão hermenêutica -, sobrepondo-se ao que já é constituído enquanto tradição. O problema da linguagem enquanto linguagem da razão formula-se, para Gadamer, a partir da unidade interna de linguagem e pensamento ${ }^{326}$.

\footnotetext{
$\overline{325}$ H.-G. GADAMER, WM, I, p. 405. "Die Sprache ist die Sprache der Vernunft selbst."

${ }^{326}$ Para a ciência lingüística o problema da linguagem apresenta-se sob a interrogação de como, diante da multiplicidade das línguas, cada língua cria condições de dizer o que quer que seja, realizando isso à sua maneira; segundo Gadamer, no entanto, a questão fundamental é procurar saber como nessa multiplicidade atua a unidade do pensar e do falar, da linguagem e do pensamento. Nesse sentido, cumpre-se a referência do hermeneuta a Humboldt e Herder como ponto de partida. A linguagem, para além de seus convencionalismos racionalistas e teológicos, converte-se em objeto de especulação na medida em que, segundo estes, as línguas constituem-se em distintos modos de ver o mundo enquanto modo de pensamento e fala. "Apesar de toda diversidade de maneiras de falar, procuramos reter a unidade indissolúvel de pensamento e linguagem tal como a encontramos no fenômeno hermenêutico, como unidade de compreensão e interpretação" (id., ibid., 406).
} 
No percurso de análise do fenômeno hermenêutico a relação de pertencimento entre compreensão e linguagem revelou, nessa unidade, o caráter universal daquilo que se refere à linguagem. Na medida em que a dimensão da linguagem, enquanto fenômeno hermenêutico, assume um significado absoluto, qualquer que seja o domínio de sua investigação, não pode prescindir desse mesmo vínculo. Isto significa que uma análise hermenêutica acerca do fenômeno proveniente de uma criação cultural da humanidade, como a arte, ao tornar-se acessível à compreensão e interpretação, subordina-se especificamente à tradição lingüística.

Convém salientar, no entanto, que tanto a "compreensão" quanto a "linguagem", sustenta Gadamer, nunca se determinam como objetos únicos de investigação, pois, em vez de constituírem-se em fatos de investigação meramente empírica, correspondem ao princípio de tudo que se põe para nós como objeto de análise. A compreensão, vale lembrar, traz sempre um momento de aplicação, enquanto a linguagem, ao abarcar a compreensão, subsiste em sua realização viva, na realização do pensar e do interpretar ${ }^{327}$.

Desse modo, Gadamer concebe a linguagem sob o horizonte de uma ontologia hermenêutica cujo ponto de partida é sua concepção como experiência de mundo. Compreender o horizonte da linguagem como um caráter fundamental inerente à experiência hermenêutica pressupõe o entendimento da relação fundamental entre linguagem e mundo.

Para Gadamer, o pensamento moderno sobre a linguagem a partir de Herder e Humboldt assume um interesse diferencial, qual seja, o de investigar a naturalidade da linguagem humana na diversidade e amplitude de sua estrutura e experiência. As línguas nada mais são que produtos da força lingüística originária do espírito humano, que, por sua vez, estando em ação, produzem a linguagem. Na reflexão do criador da filosofia moderna da linguagem, Humboldt, interpreta Gadamer, as línguas têm de ser compreendidas como acepção de mundo, de modo que a formação da linguagem depende do modo pelo qual o acontecer humano vai se diferenciando em sua forma interior. Um de seus grandes méritos foi ter conseguido captar na amplitude da linguagem a diversidade de formas de sua manifestação. O que confere, todavia, um maior significado do pensamento de Humboldt ao problema da hermenêutica é a formulação de um dos significados específicos de linguagem como "acepção do mundo", ressaltando como sua essência a execução viva do falar, sua

${ }^{327} \mathrm{O}$ aprofundamento da relação entre linguagem e compreensão requer, obviamente, na reflexão hermenêutica de Gadamer uma abordagem histórico-conceitual acerca dessa unidade que vai desde a inconsciência lingüística dos gregos, desprovidos que eram, a princípio, de um termo designativo para a linguagem, até sua cunhagem conceitual propriamente dita, ao longo da história do pensamento ocidental - linguagem e logos, linguagem e verbum. Para nosso propósito, nos restringiremos à significação da linguagem como horizonte de uma ontologia hermenêutica. 
energeia lingüística. A linguagem, desde seu começo, revela um caráter essencialmente humano, remetendo-nos, conseqüentemente, a uma perspectiva antropológica de largo alcance. É enquanto linguagem que os homens têm um mundo, de modo que o mundo apenas existe para os seres humanos, tornando-se um mundo humano, sob a especificidade de sua forma lingüística. Mas a relação entre linguagem e mundo, que aí se apresenta como nuclear, não sustenta nenhuma autonomia, seja da linguagem ou do mundo. "Não somente o mundo é mundo, apenas na medida em que vem à linguagem - a linguagem só tem sua verdadeira existência no fato de que nela se representa o mundo. A humanidade originária da linguagem significa, pois, ao mesmo tempo, a lingüisticidade do estar-no-mundo do homem”328. Isso também significa que ter um mundo ${ }^{329}$ implica assegurarmos um comportamento livre em face daquilo que, ao se pôr diante de nós tal como é, vem a nosso encontro. É, pois, essa liberdade diante do mundo circundante, na medida em que o homem exercita a capacidade lingüística livre que garante e assegura a constituição lingüística do mundo: a relação homemmundo. Esse elevar-se sobre o mundo circundante perfaz a relação geral lingüística do homem com o mundo; ou seja, tem um sentido humano e é uma realização lingüística de caráter variável, dada sua abertura para expressar uma mesma coisa em suas múltiplas possibilidades. Eis por que, segundo Gadamer, o caráter de linguagem da experiência humana amplia nosso horizonte de análise da experiência hermenêutica, fazendo falar os mais diferentes discursos e as mais diversas experiências de linguagem.

Assim como a tradução remete-nos à possibilidade de entendermos para além dos limites de nossa própria língua, assim também nosso próprio mundo da linguagem não pode ser tomado como uma barreira para adquirir conhecimentos, já que abarca tudo o que, ao se expandir, estimula nossa percepção. Por mais que subsistam diferentes tradições lingüísticas e culturais, o que se representa nelas é sempre um mundo estruturado lingüisticamente, um mundo humano aberto a ampliações e ao acesso da alteridade. Como nos diz Gadamer:

“[...] introduzindo-nos em mundos lingüísticos estranhos, isso não quer dizer, de modo algum, que abandonemos ou neguemos nosso próprio mundo. Como viajantes, sempre voltamos para casa com novas experiências. Como emigrantes que jamais irão voltar para casa, também não poderemos esquecer totalmente [...] A estruturação lingüística de nossa experiência do mundo está em condições de abarcar as relações vitais mais diversas" "330.

\footnotetext{
${ }^{328}$ H.-G. GADAMER, $W M$, I, p. 447.

${ }^{329} \mathrm{O}$ significado do conceito de mundo no modo pelo qual aí está sendo exposto não corresponde ao conceito de mundo circundante (Umwelt), que, por sua vez, aplica-se ao mundo humano e mediante a sua expansão a todos os seres vivos no mundo, adverte Gadamer.

${ }^{330}$ H.-G. GADAMER, WM, I, p. 452.
} 
Desse modo, a linguagem determina e revela nosso comportamento enquanto ser-no-mundo, legitimando-o como ele aparece para nós. Isso vale tanto para nosso comportamento cotidiano natural como para a ciência, cuja verdade a ser determinada pelo seu aparato metodológico constitui-se tão-somente relativa a um particular comportamento em face do mundo, e de modo algum à sua totalidade.

Uma vez voltados à imediatez prosaica de nossa contemplação do mundo e de nós mesmos, é a linguagem que confere clareza àquilo que se apresenta como real; é ela que, enquanto um envolvimento prévio de abertura, nos retém e, ao mesmo tempo, transforma a presença de nossa finitude. Reconhecendo a linguagem como seu fio condutor central, a hermenêutica conduz-nos ao reconhecimento de que o eu e o mundo estão atados por um laço de pertencimento originária lingüístico-ontológico.

$\mathrm{Na}$ linguagem representa-se o próprio mundo. Assim, qualquer que seja o ente que nos interpele e busque ser reconhecido por nós, não pode prescindir desse caráter de lingüisticidade inerente à nossa experiência do mundo. É enquanto seres de linguagem que compreendemos, interpretamos e instauramos experiências de mundo. Cabe esclarecer, todavia, conforme observa Gadamer, que essa relação entre mundo e linguagem não implica conceber o mundo como objeto da linguagem, mas, pelo contrário, significa que o fenômeno da arte, como os demais objetos, ao se porem como objetos de conhecimento, são necessariamente abrangidos por este horizonte. Tomando-se o mundo em sua estruturação lingüística enquanto um todo abrangente, este está totalmente desprovido do caráter de objeto, não podendo integralmente estar dado na experiência. Viver num mundo lingüístico é, desde já, inserir-se em sua totalidade, pois "não existe nenhum lugar fora da experiência lingüística de mundo a partir do qual este pudesse converter-se a si mesmo como objeto" ${ }^{, 331}$.

A esse propósito, conhecer o ser em $\mathrm{si}^{332}$ das coisas mediante essa primazia significativa da linguagem não significa assegurar um conhecimento, no sentido da ciência moderna, com vistas à determinação objetiva e à possessão da coisa. Bem pelo contrário, o "em si”, como assim o pensou Max Scheler - aqui muito bem lembrado por Gadamer -,

\footnotetext{
${ }^{331}$ Id.ibid., p. 456.

332 O referido conceito, segundo Gadamer, possui o caráter de uma determinação volitiva, totalmente independente daquilo que queremos. Trata-se de uma disponibilidade que se integra aos objetivos próprios da ciência. "Esse conceito do ser em si, como se vê, só se corresponde na aparência com o conceito grego do к $\alpha \theta$ avio. Este último se refere basicamente à diferença ontológica entre o que é um ente segundo sua substância e sua essência e aquilo que nele pode ser e que é cambiante. O que pertence à essência permanente de um ente é conhecido também num sentido pregnante, isto é, detém sempre uma correspondência prévia com o espírito humano. Por outro lado, o que é 'em si', no sentido da ciência moderna não tem nada a ver com essa diferença ontológica entre o essencial e inessencial [...]" (id., ibid., p. 454).
} 
também se define pela sua relatividade a um modo de querer e saber. Seu conhecimento de modo algum se limita às prerrogativas de um saber dominador baseado nos objetivos de uma reflexão que investiga a natureza em seu conjunto - o que é pertinente às ciências modernas da natureza. De qualquer forma, independentemente da ciência da qual se esteja tratando, a investigação do em si é sempre precedida pelo esboço da região de seu objeto, sendo seu conhecimento restrito unicamente a esse domínio. Daí que o ser em si é sempre "[...] relativo à colocação do ser dentro de seu questionamento",333.

Isso de alguma forma nos remete ao caráter universal da linguagem na medida em que nos possibilita falar de suas mais diferentes determinações, até mesmo do caráter específico

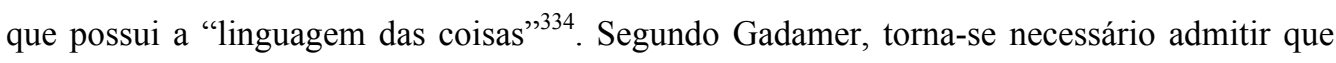
não ouvimos suficientemente a linguagem das coisas, assim deveríamos escutá-la melhor, em vez de a submetermos demasiadamente ao caráter instrumental e esquemático da ciência. Referir-se à linguagem das coisas também significa atentarmos ao fato de que essas não se constituem simplesmente em instrumentos de uso, mas em algo que, em si, tem consistência, o que as priva de coação. O que essa expressão recorda em nós é, pois, o próprio "em si" da coisa, "[...] é como uma linguagem que é preciso ouvir [...] A expressão 'linguagem das coisas' não é portanto, uma verdade mitológico-poética [...] mas a recordação em todos nós adormecida do ser próprio das coisas, que podem ainda ser o que elas são",335. Sob um determinado aspecto, as expressões "linguagem das coisas" e "natureza das coisas" têm o mesmo sentido, já que convergem em uma recordação necessária ante o arbítrio abusivo de seu uso.

Conferir ênfase a essa reflexão sobre a necessidade de ouvir a linguagem das coisas pode ainda ser entendida como uma crítica à própria noção de esvaziamento da linguagem. Já em Heidegger, esta provém de uma ameaça à essência do homem, que, embora a cultive em determinado uso, algumas vezes é incapaz de escapar de um requinte de estilo lingüístico. Neste apelo ao homem, a caminho da proximidade do ser, o "cuidado" impõe-se como tentativa de reconduzi-lo ao reconhecimento da unidade ser e linguagem. Do contrário, a orientação segue "[...] o fato de que a linguagem, sob o domínio da metafísica moderna, extravia-se, quase, invencivelmente de seu elemento. A linguagem recusa-nos ainda sua

\footnotetext{
${ }^{333}$ Id., ibid., p. 456.

${ }^{334} I d$., "Die Natur der Sache und die Sprache der Dinge", in: WM II, p.66-76

${ }^{335}$ Id., ibid., p. 68 .
} 
essência: que ela é a casa da verdade do ser. A linguagem abandona-se, ao contrário, a nosso puro querer e à nossa atividade, como um instrumento de dominação sobre o ente ${ }^{\text {„336. }}$.

O fenômeno da compreensão não pode ser indiferente às peculiaridades da situação hermenêutica. Aquela que se desenvolve na conversação entre duas pessoas não é a mesma que se põe em face daquilo que Droysen denominou manifestações vitais que se fixam num prazo bastante duradouro ${ }^{337}$, como é o caso dos textos e dos produtos artísticos. Compreendêlos só é possível por meio do outro, de seu intérprete; falam a partir do momento em que seu intérprete converte seus signos em sentido novo. A linguagem da obra de arte é a linguagem pela qual ela é conservada e transmitida em seu caráter genuíno de experiência; ou seja, ao nos dizer algo, diz também a outros. Conforme assinala Gadamer, o que vale para o discurso também vale para a compreensão da arte. Assim como a compreensão do discurso não equivale à compreensão literal do que está sendo dito mediante o significado das palavras, da mesma forma a compreensão da obra de arte sempre nos remete para além daquilo que o dito declara. Pertence à compreensão sempre uma expectativa de sentido. Acrescenta, todavia, Gadamer: "Aqui, há algo a mais que expectativa de sentido; há aqui o que se quisera chamar 'sentir-se alcançado' [Betroffenheit] pelo sentido do dito. Toda experiência da arte entende não apenas um sentido reconhecível [...] A obra de arte que nos diz algo confronta-nos com nós mesmos" ${ }^{\$ 338}$. Sentir-se alcançado por sua linguagem declarativa significa, ao mesmo tempo, pôr-se em descobrimento, descobrir o que outrora permanecia encoberto. Por isso, compreender a arte em sua constituição de linguagem implica deixar falar a autocompreensão de cada um. É o caráter presente de sua atualidade (Gegenwartigkeit) que faz com que a obra de arte ponha-se como testemunho de encontro do homem consigo mesmo e assim se converta em linguagem. A experiência da arte enquanto experiência de linguagem é uma experiência de pronunciamento e revelação de sentido. "A linguagem da arte refere-se ao excesso de sentido que reside na obra mesma”339.

Enquanto experiência de pronunciamento e confronto, ela remete-nos à sua essência interpretativa, e isso pode ser evidenciado, ressalta Gadamer, desde os acontecimentos mais rotineiros, ilustrados, por exemplo, quando então procedemos a uma comparação feita entre quadros identificando contrastes, ou mesmo num procedimento de leitura sucessiva de poemas, de modo que seja permitido a um intérprete ouvir o outro. O exercício de comparar

\footnotetext{
${ }^{336}$ M. HEIDEGGER, Sobre o humanismo, p. 152.

${ }^{337}$ Cf. DROYSEN, Historik, p. 63, citado em H.-G. GADAMER, WM, I, p. 391.

${ }^{338}$ H.-G. GADAMER, Ästhetik und Hermeneutik, p. 6.

${ }^{339}$ Id., ibid., p. 7.
} 
apresenta-se aqui como via de demonstração em que a interpretação de uma obra articula-se como se fosse a leitura de um texto.

Sob um ponto de vista mais genérico, o que justifica a conversação hermenêutica é precisamente sua possibilidade de elaborar uma linguagem comum, todavia não no sentido de uma preparação instrumental que vise um acordo, mas no intuito da compreensão real possibilitada pela comunicação. Ao nos pormos, por exemplo, diante da tarefa de identificar o significado de um texto, sua resposta não pode restringir-se à apreensão e controle de um ponto de vista ou opinião como a de quem chegou a um acordo. À compreensão de um texto, é necessariamente inerente o horizonte de idéias do intérprete. Por isso, diz Gadamer:

\begin{abstract}
"O que um texto quer dizer não se pode comparar, com um ponto de vista fixo, inamovível e obstinado, que põe a quem quer compreender sempre somente uma questão: como o outro pôde chegar a uma opinião tão absurda? Nesse sentido, na compreensão não se trata seguramente de um 'chegar a acordo histórico' que reconstrói a gênese do texto [...] $\mathrm{O}$ próprio horizonte do intérprete é determinante [...] como uma opinião e possibilidade que se aciona e se põe em jogo e que ajuda a apropriar-se de verdade do que diz o texto" 340 .
\end{abstract}

Retomando-se a idéia referente à lógica da pergunta e da resposta, entender um texto implica tomá-lo como resposta a um emaranhado de perguntas que o próprio intérprete põe. Não se trata, porém, de apropriar-se do texto alterando seu sentido original, mas de evidenciar que uma melhor compreensão é sempre aquela a partir da qual o caráter lingüístico do texto, inevitavelmente, alcança seu intérprete, permitindo a este conferir seus acentos, tonalidades e ênfases, e empreendendo aquilo que Gadamer denomina uma super-iluminação (Überhellung). Desse modo, o fenômeno hermenêutico enquanto uma expressão especial da linguagem no pensamento instaura a interpretação como uma relação vital histórica, a partir da qual "a lingüisticidade da compreensão é a concreção da consciência histórico-efeitual" "141. Parece então ficar claro que compreender, em hipótese alguma, pode querer significar uma transposição para o universo do autor, na tentativa de recriar suas vivências, como pensava a hermenêutica psicológica de Schleiermacher e Dilthey.

$\mathrm{O}$ próprio Heidegger já parece antecipar esse sentido fundamental atribuído à compreensão e interpretação. Contrariando o sentido moderno de hermenêutica enquanto uma

\footnotetext{
${ }^{340}$ H.-G. GADAMER, WM, I, p. 391. Do ponto de vista da importância do problema da linguagem para a filosofia, Gadamer lembra-nos a importância do romantismo alemão no reconhecimento da importância da lingüisticidade para o processo do compreender. Pressuposição para a qual compreender e interpretar constituem a mesma coisa. Desde o romantismo, a linguagem torna-se reconhecida como um medium em que se realiza a compreensão, sendo a interpretação a forma em que aquela se realiza. "Todo compreender é interpretar e todo interpretar se desenvolve no medium de uma linguagem que pretende deixar falar o objeto e é, ao mesmo tempo, a linguagem própria de seu intérprete" (id., ibid., p. 392).

${ }^{341}$ Id., ibid., p. 393.
} 
teoria da interpretação, o filósofo alemão, lembremos, entende-a como auto-interpretação da facticidade, o que remete ao próprio significado de Hermes; enquanto ser fáctico, o homem anuncia-se, interpretando-se em termos de encontro, apreensão e concepção de si mesmo, comunicando-se. Na verdade, Hermes carece de interpretação, devendo tornar-se acessível a si mesmo o seu próprio ser. Por isso a compreensão não pode ser reduzida a um comportamento meramente intencional da consciência, mas a um modo em que o Dasein desperta para si mesmo vigiando-se em sua facticidade. A compreensão, de fato, cresce no horizonte de suas possíveis e diversas interpretações, projetando-se a um entender-se a respeito de algo, pronunciando-se lingüisticamente e suscitando interlocuções.

Há, portanto, uma relação essencial entre linguagem e compreensão cujo significado também aponta para a consideração de dois outros aspectos fundamentais: a lingüisticidade (Sprachlichkeit) como determinação do objeto hermenêutico e como determinação da execução hermenêutica. Aqui reside uma tese fundamental apresentada e desenvolvida por Gadamer em sua hermenêutica: a lingüisticidade determina não apenas o objeto, mas a realização do compreender.

Inicialmente, é tendo em vista o caráter da tradição que esse primeiro nível de relação se estabelece. Tradição aqui retomada no sentido estrito da palavra, não apenas como um resíduo ou relíquia do passado que permaneceu, mas fundamentalmente como entrega e transmissão. Na formulação gadameriana, relembremos, tradição não quer dizer certamente mera conservação, mas transmissão. A transmissão, por conseguinte, inclui a proposição de que "não se deixe nada imutável e meramente conservado, mas que se aprenda a dizer e captar o velho de modo novo" ${ }^{\text {342 }}$. Assim como a lingüisticidade de nossa experiência de mundo determina nossa consciência histórica, a tradição tem sua essência expressa em sua própria lingüisticidade e é por meio desta que ela chega até nós. Trazida à linguagem, é desse modo que a compreendemos e a interpretamos. No horizonte de suas trilhas, o que se impõe a nós como objeto de interpretação é, fundamentalmente, algo que se transmite e se pronuncia à nossa curiosidade. São mitos e lendas, costumes, configurações plásticas e poéticas que se dispõem, seja em uma tradição oral ou escrita, mediante signos algumas vezes obscuros e quase indecifráveis. A tradição, embora expresse o universo de tudo o que se refere à linguagem, sua significação hermenêutica só se torna plena quando essa tradição se faz escrita. Ora, essa primazia da tradição escrita sustentada pelo hermeneuta justifica-se porque sob sua forma aquilo que é transmitido se faz simultâneo a qualquer presente. A escrita, além

\footnotetext{
$\overline{{ }^{342} \text { H.-G. GADAMER, Aksch., p. } 139 .}$
} 
de permitir acesso ao que é transmitido, cumpre a exigência de uma abertura da experiência, ampliando e alargando os horizontes do mundo mediante novas dimensões interpretativas.

A essa tradição pertence o caráter de transcendência do sentido, a transcendência da escrita $^{343}$. A partir da tradição escrita, Gadamer identifica dois momentos fundamentais constitutivos da linguagem: a contingência e a idealidade. Por um lado, seu sentido emerge de situações históricas específicas, e sob a forma da escrita engendra-se a liberação da linguagem para outras referências, a transcendência do sentido acima de suas contingências históricas originais. É a "idealidade da palavra" elevando-se acima do caráter passageiro da finitude, ampliando em profundidade os horizontes do mundo. Ao nos atingir, o sentido que se articula na tradição escrita não se constitui apenas em presentificação de situações passadas.

“A tradição escrita não é somente uma porção de um mundo passado, mas está sempre acima deste, na medida em que se elevou à esfera do sentido que ela mesma enuncia. Trata-se da idealidade da palavra que eleva o todo lingüístico acima da determinação finita e efêmera que convém aos demais restos do que já foi [...] o portador da tradição não é este manuscrito, como uma parte de então, mas a continuidade da memória" ${ }^{344}$.

Memória não enquanto pedaços de lembrança do passado, mas enquanto transmissão simultânea, coexistência de passado e presente, reconhecimento da humanidade passada em sua relação geral com o mundo. A consciência do leitor comunica-se com a tradição histórica.

Uma vez que a compreensão define-se pelo princípio da aplicação, compreender aquilo que é transmitido implica sempre a participação nele; participação não enquanto uma possível relação interpessoal entre o leitor e o autor do escrito, mas efetivamente enquanto participação do sentido daquilo que está sendo dito e que se põe diante de nós; quando, por exemplo, compreendemos mediante a expressão de nossas próprias palavras. No entanto, atingidos por essa tradição, na medida em que esta faz emergir um todo de sentido, isto se dá pelo fato de que, sustenta Gadamer, "na esfera da escrita [...] a linguagem atinge sua

\footnotetext{
${ }^{343} \mathrm{Na}$ compreensão da "transcendênncia da escrita" está precisamente um ponto de encontro entre a hermenêutica filosófica de Gadamer e a hermenêutica de Ricœur, quando então este último refere-se à "função hermenêutica do distanciamento": "É essencial a uma obra literária, a uma obra de arte em geral, que ela transcenda suas próprias condições psicossociológicas de produção e que se abra, assim, a uma seqüência ilimitada de leituras diferentes. Em suma, o texto deve poder, [...] descontextualizar-se de maneira que se deixe recontextualizar em uma nova situação [...]" (P. RICEUUR, Interpretação e ideologias, p. 53).

${ }^{344}$ H.-G. GADAMER, $W M$, I, p. 394. Sobre a questão da memória, Gadamer ratifica sua relação com a história sustentada por Hegel em $A$ razão na história e então nos diz: "Neste sentido parece estar justificada a idéia hegeliana de equiparar o começo da história com o surgir de uma vontade de tradição, de "permanência de recordação'. A escrita não é um simples acaso ou uma mera adição que não altera qualitativamente nada no progresso da tradição oral. É claro que também sem escrita pode dar-se uma vontade de sobrevivência, de permanência. Mas somente a tradição escrita pode ir mais além da mera permanência de resíduos de uma vida passada, a partir dos quais é possível ao ser-aí [Dasein] reconstruir outra existência [Dasein] " (id., ibid., p. 395).
} 
verdadeira espiritualidade ${ }^{345}$. Em sua relação essencial com a linguagem, a compreensão não pode ser tomada como assimilação de um estado isolado de coisas, captura objetiva de significados e de expressões determinada por um sujeito; bem pelo contrário, é sempre participação num sentido, o inserir-se numa tradição, numa conversa, num diálogo, a partir do qual o que é dito recebe sentido.

Mas, além da relevância da tradição como objeto preferencial de compreensão, à relação fundamental entre linguagem e compreensão corresponde, também, o processo de execução hermenêutica. Desenvolver essa determinação significa, segundo Gadamer, tomar como base o paradigma da interpretação (Auslegung). O ponto de partida é o postulado de que toda compreensão já é sempre interpretação. Compreender algo é, pois, sempre interpretá-lo, considerando-o a partir de nossas intenções, das intenções no horizonte das quais nos movemos e nos expressamos. Assim como o historiador, diz Gadamer, dominado pelo aparato metodológico e pelo universo de seus preconceitos, objetiva ingenuamente descrever a peculiaridade histórica de seus objetos sem atentar devidamente para sua origem ou, em contrapartida, desloca e amplia essa ingenuidade objetivando uma compreensão histórica, exclusivamente, a partir dos conceitos da época; da mesma forma o êxito deste postulado impõe ao intérprete não poder abrir mão de si, deixando-se de lado. Daí a afirmação do hermeneuta:

“[...] o que a exigência legítima da consciência histórica, de compreender cada época a partir de seus conceitos, tem realmente em mente é completamente diferente. O requisito de pôr de lado os conceitos do presente não postula um deslocamento ingênuo ao passado [...] A consciência histórica compreende a si mesma erroneamente, quando, para compreender pretende desconectar o que unicamente torna possível a compreensão. Pensar historicamente quer dizer, na realidade, realizar a conversão entre o que acontece aos conceitos do passado, quando neles procuramos pensar [...] implica sempre uma mediação entre aqueles conceitos e o próprio pensar,"346.

Partindo do pressuposto de que compreender é interpretar, e toda interpretação implica um pôr em jogo o caráter prévio dos conceitos, fazendo o texto vir à fala, é necessário que a linguagem falada atinja e alcance o outro; seja compreendida pelo outro. Eis por que a vida histórica da tradição permanece aberta a diferentes apropriações e interpretações, de modo que a idéia de uma interpretação ideal comprometeria a própria essência da tradição. Bem pelo contrário, o procedimento de interpretar implica sempre um inserir-se na situação, ou seja, "entrar nos eixos da situação hermenêutica a que pertence" $" 347$.

${ }^{345}$ H.-G. GADAMER, WM, I, p. 394. Embora os fundamentos da hermenêutica filosófica dêem ênfase à estrutura do diálogo, o que aqui fica claro é a primazia hermenêutica da escrita diante da tradição oral da fala. Isso se justifica tendo em vista o distanciamento do problema hermenêutico de tudo o que é psicológico.

${ }^{346}$ H.-G. GADAMER, $W M$, I, p. 400-1.

${ }^{347}$ Id., ibid., p. 401. 
Portanto, é graças ao caráter da lingüisticidade que a interpretação define-se radicalmente pela sua referência à alteridade. Embora um texto permaneça o mesmo, compreendê-lo é sempre aplicá-lo a nós mesmos. Ressalta Gadamer que cada diferença interpretativa, todavia, tendo em vista o caráter de sua lingüisticidade, reivindica sua pretensão de verdade. Interpretar é inserir-se num sentido Ainda quanto a elucidar o postulado de que compreender é interpretar, o fato de que em toda compreensão a interpretação está potencialmente contida não significa que esta última seja um meio para assegurar a compreensão; esta apenas integra, acrescenta seu processo, possibilitando ao conteúdo seu modo de fazê-lo vir à fala.

Dada a relação essencial de pertencimento entre compreensão e linguagem, no entanto, por mais que a lingüisticidade imponha-se em sua primazia quando se trata de compreender algo, até mesmo as obras de arte, parece também ser freqüente a constatação de sua insuficiência para expressar o que sentimos. A concepção segundo a qual a lingüisticidade revela o objeto hermenêutico e possibilita a realização hermenêutica significa que toda compreensão está condicionada, em princípio, a uma estrutura lingüística de sentido, e é por isso que ela efetua-se lingüisticamente. Mas em que medida a compreensão é incondicionalmente lingüística? A experiência da arte é apresenta por Gadamer como uma determinação que muito bem ilustra esse questionamento, na medida em que também amplia a própria compreensão do caráter lingüístico de nosso entender. Como entender a primazia da lingüisticidade, se, muitas das vezes, “em face da presença avassaladora [überwältigenden] de obras de arte, a tarefa de reunir em palavras o que elas nos dizem parece uma empresa infinita e de uma desesperadora distância" ${ }^{348}$ ? Como sustentá-la, se a linguagem por vezes não dá conta de expressar nossos próprios sentimentos, se, diante de uma peça musical, uma configuração plástica, as próprias palavras sobram, indicando que ainda resta algo?

Ora, é importante considerar um pouco mais o caráter essencialmente lingüístico da interpretação no âmbito de suas variações. Se, por um lado, "[...] quando se trata de compreender e interpretar textos lingüísticos, a interpretação no medium da linguagem, mostra com clareza o que a compreensão é sempre: uma apropriação do que foi dito, de maneira que se converta em coisa própria" ${ }^{349}$; por outro, mesmo num âmbito que não seja em si de natureza textual, como, por exemplo, as configurações plásticas da arte ou mesmo a arte da música, também nessas está necessariamente pressuposta a lingüisticidade. Quando se trata de

\footnotetext{
${ }^{348}$ H.-G. GADAMER, WM, I, p. 405.

${ }^{349}$ Id., ibid., p. 402.
} 
entender algo, o fenômeno primordial da lingüisticidade sempre se determina e se manifesta independentemente de suas expressões. O que não podemos esquecer é que a obra de arte, na condição de um enunciado que é, ao nos dizer algo, requer uma resposta. Nesse interpelar, inerente a sua natureza, ela se põe como linguagem. Em suas mais diversas expressões, elas nos interpelam, ativando nossa admiração, porque são essencialmente lingüísticas e, à sua maneira, integram o movimento lúdico de sua representação.

Ainda para ratificar o caráter universal da lingüisticidade como fenômeno hermenêutico, Gadamer lança mão do fenômeno de reprodução (Reproduktion) ao qual algumas obras de arte estão sujeitas. Aqui Gadamer confere ênfase ao caráter de reprodução artística, seja de uma peça musical ou uma representação cênica, quando numa releitura. Afirma Gadamer: "Essa reprodução [...] é primordialmente o que permite à obra de arte manifestar-se autenticamente. Somente nela cumpre seu objetivo a linguagem, sob a qual está um texto musical ou um drama" ${ }^{, 350}$. Do ponto de vista do seu caráter espaciotemporal, a exterioridade de uma encenação não adquire ou mesmo alcança uma autonomia enquanto obra. Bem mais do que isso, à música, à poesia, à expressão cênica em sua execução, é sempre imprescindível o interpretar. A arte é, pois, uma interpretação reprodutiva, e, enquanto uma interpretação veiculada pelo artista, este busca tornar sua criação convincente e correta, sendo, para tanto, capaz de justificá-la interpretativamente em sua forma de linguagem. E, se um artista, considerando sua autonomia, resiste a uma interpretação lingüística feita a partir de sua obra, apontando a insuficiência desta leitura, ele o faz sob o princípio de existência de uma outra interpretação ainda mais convincente.

Ademais, tomando-se a arte com base nessa imbricação interna interpretaçãocompreensão, Gadamer ressalta o caráter de "acidentalidade fundamental" inerente à interpretação. Por maior que seja a força poética de uma expressão artística, à sua interpretação é sempre inerente um aspecto acidental; o que se torna bastante claro nos atos de interpretar, executar, traduzir, ou mesmo ler. A execução pressupõe sempre uma interpretação, uma "sobre-iluminação" (Überhellung). A execução ou composição de um poema, por exemplo, inevitavelmente, está sujeita às variações enfáticas de sua representação, de sua presença mímica. $\mathrm{O}$ que também garante um acréscimo na experiência da compreensão é que "a interpretação não pretende pôr-se no lugar da obra interpretada",351

\footnotetext{
${ }^{350}$ H.-G. GADAMER, $W M$, I, p. 403.

${ }^{351}$ Id., ibid., p. 582.
} 
Fundamentalmente é isto que justifica as diferentes acepções subjacentes às interpretações e reproduções.

Numa experiência natural do mundo cunhada lingüisticamente, seu domínio não se dá, como na elaboração científica, tendo em vista os desígnios de sua objetividade consoante a eliminação dos elementos subjetivos do conhecer. Isto por que, quando falamos, não disponibilizamos as coisas sob um ponto de vista calculável; a formulação do enunciado e do juízo apenas expressa uma forma do comportamento lingüístico e da própria vida do ser humano. Eis por que a determinação lingüística da experiência natural do mundo é compreendida pelo propósito da objetividade científica apenas como fonte de preconceito. Nesse sentido, considerando a experiência da arte como uma forma de experiência humana de mundo, indagamos: o que a experiência da arte ganha em sua acepção lingüística? Essa questão parece definir-se pela constatação de que a experiência em questão, não podendo ser calculada como um dado, nela o mundo não se objetiva como um dado fixo, como uma certeza que se confirma, apenas mostra-se aos seres humanos, declara-se, reivindicando deles uma resposta, um horizonte interpretativo; mostra-se como significante que conduz o ente ao horizonte de um vir-à-fala.

Cabe aqui enfatizar a observação de que, segundo Gadamer, é a partir do paradigma da interpretação que as ciências humanas têm sua autonomia reintegrada, no tocante ao processo de reconquista da autonomia metodológica: "É aqui - e não no ideal metodológico da reconstrução racional que domina a moderna ciência natural da matemática - onde se poderá reconhecer a compreensão que se exerce nas ciências do espírito ${ }^{\text {„352 }}$. Ao submeter a análise do fenômeno hermenêutico à radicalidade da relação linguagem-mundo, Gadamer confere à experiência humana a primazia fundamental da lingüisticidade, desse fazer o mundo vir à fala. $\mathrm{O}$ acontecimento da linguagem constitui-se, nessa reflexão, o indício da finitude humana, seja porque o desenvolvimento e a formação da língua dependem diretamente do movimento de trazer à fala a experiência humana do mundo, seja porque é apenas como linguagem que podemos desenvolver uma experiência hermenêutica do mundo. Nas palavras de Gadamer: "Somente o medium da linguagem, por referência ao todo dos entes, pode mediar a essência histórico-finita do homem consigo mesmo e com o mundo",353.

Em Verdade e método as reflexões desenvolvidas sobre a linguagem realçam a experiência da arte como uma determinação ilustrativa, elucidativa, dado seu caráter

\footnotetext{
${ }^{352}$ H.-G. GADAMER, $W M$, I, p. 460.

${ }^{353}$ Id., ibid., p. 461.
} 
diferencial enquanto fenômeno hermenêutico - lingüístico - , e isso se verifica por, pelo menos, dois motivos. Primeiro porque a particularidade hermenêutica que possibilita a relação entre o fenômeno da arte e a interpretação, tendo em vista suas especificidades, amplia a própria compreensão do fenômeno da lingüisticidade em seu horizonte ontológico-existencial. Além disso, em consonância com aquilo que fora anunciado pelo autor desde o início da obra: a experiência da arte, uma vez submetida a uma reflexão hermenêutica, constitui uma advertência aos domínios da consciência científica. Gadamer, tendo como pressuposto seu desenvolvimento acerca da "crítica da consciência estética" e, por extensão, seu princípio de história dos efeitos (Wirkungsgeschichte), ao submeter a experiência artística à estrutura de implicação interpretar-compreender, está convicto de que a natureza da linguagem artística ultrapassa os limites da significação inerente à interpretação científica.

Além desse argumento exposto acima que, de modo bastante claro se constitui com um dos impulsos reflexivos iniciais de Verdade e método, torna-se ainda necessário insistirmos um pouco mais no significado do termo "declaração" (Aussage). Como bem observa Gabilondo ${ }^{354}$, quando Gadamer ressalta que as obras de arte também se definem por

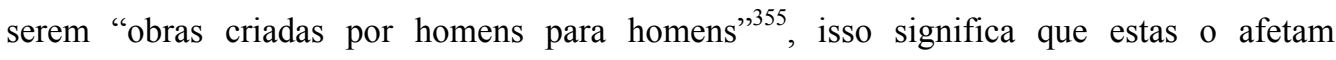
significativamente, seja considerando sua imediata atualidade (Gegenwärtigkeit) ou mesmo realçando sua superioridade sobre o tempo (Zeitüberlegenheit). Desse modo as obras de arte podem nos alcançar de modo imediato, convidando-nos a nos demorarmos nelas. Ademais, observa Gadamer que, normalmente, apenas se fala de "obra" (Werk) quando nos referimos às obras de arte. Isso se justifica porque tanto os produtos artesanais quanto os industriais estão sempre voltados a uma função, a um uso; ao passo que a obra de arte tem a particularidade de sua existência em seu estar voltada para si. O seu estar- aí emerge e vislumbra uma contemplação. Ora, mas como entender que a obra de arte emerge em sua potência poética? Para tanto Gadamer remete-se ao conceito de enérgeia, na medida em que esse se refere ao ser do movimento, à sua realização efetiva, à sua atualidade. Diz o filósofo: "Eu creio que Aristóteles descreve enérgeia por meio da palavra usada 'ao mesmo tempo' (háma) com o fim de designar simultaneidade imanente à duração",356

A retomada conceitual desse conceito aristotélico possibilita ao horizonte de reflexão hermenêutico-filosófico uma perspectiva nova para considerar o caráter de linguagem imanente ao modo de ser da arte. A experiência hermenêutica da arte implica, por conseguinte

\footnotetext{
${ }^{354}$ A. GABILONDO., Introducción:Leer Arte.,in: H.-G. GADAMER, Estética y hermenéutica., p. 25.

${ }^{355}$ H.-G. GADAMER., WM, I, p. 142

${ }^{356}$ Id. Wort und Bild - so wahr, so seind - ., in: WM, 8, p.387.
} 
em sua reconstituição como pura enérgeia. A arte é declarativa porque ao emergir, ela, mais do que produzir efeitos, nos convida a demorar, interpelando-nos como em um diálogo. "A obra de arte é uma declaração que não constitui nenhuma frase enunciativa, embora seja aquilo que mais diz. É como um mito, como uma lenda porque tanto retém o que diz como o brinda",357

Tomemos como exemplo de referência a palavra poética. Nela, como em qualquer outro acontecer lingüístico, suas expressões sempre ilustram a transformação das coisas em manifestação do modo com que vivemos no mundo. As palavras algumas vezes se desgastam, ou mesmo se mantêm em sentido irônico, outras vezes prevendo até sua substituição por outras. Trata-se da maneira de manterem-se vivas no mundo. Mas a palavra poética, também ela, "[...] se converte com freqüência numa prova do que é verdadeiro, na medida em que o poema desperta uma vida secreta em palavras que pareciam desgastadas e consumidas, e nos esclarece assim sobre nós mesmos" ${ }^{\$ 358}$. Em seu caráter poético, a linguagem constitui-se em expressão de realização de nosso comportamento em face do mundo da vida.

\footnotetext{
${ }^{357}$ Id.,ibid., p. 388

${ }^{358}$ Id., ibid., p. 453.
} 


\section{ARTE E VERDADE}

Uma vez estabelecidas as aproximações necessárias entre a experiência da arte em seu caráter essencialmente lingüístico, passemos à questão nuclear resgatada pela hermenêutica filosófica no tocante a esse fenômeno hermenêutico: a arte como experiência de verdade. Admitindo que, do ponto de vista de seu desenvolvimento em Verdade e método, a condição de possibilidade dessa abordagem é assegurada pela tarefa da crítica estendida à consciência estética e histórica, a questão que se põe é analisar, no interior da filosofia de Gadamer, os modos de pensar a possibilidade da arte enquanto verdade, tendo em vista a própria noção de "destruição da estética". Qual o horizonte a partir do qual essa verdade mostra-se possível e necessária? Tornou-se claro para nós que o âmbito de análise dessa questão em Verdade e método atende às necessidades de uma reivindicação de verdade para além da esfera científico-metodológica voltada para a captação objetiva das coisas, vislumbrando suas certezas. Entretanto, uma vez que a análise ontológico-hermenêutica sobre a arte constituiu-se paradigmática para a investigação sobre a verdade, torna-se necessário explicitá-la na qualidade de verdade hermenêutica. Isso só é possível pressupondo sua caracterização ontológica enquanto esfera de linguagem. A relação entre arte e verdade, portanto, culmina em um aprofundamento acerca de sua radicalidade lingüística (Sprachlichkeit). A arte é verdade porque é uma experiência cuja estrutura revela-se como um fazer vir-à-fala.

Dessa forma, orientados pelos princípios fundamentais da hermenêutica filosófica de Gadamer, podemos afirmar que a pergunta pela verdade como problema filosófico pertinente ao universo do fenômeno artístico desenvolve-se como extensão do caráter especulativo da linguagem. Atentando à natureza da linguagem humana, parecem estar claras suas diversas funções e dimensões. Vemos então a linguagem cognitiva, pela qual são concedidos os nomes e enunciados a descrever os estados de coisas. Também a linguagem comunicativa que nos permite descobrir o mundo, na medida em que nos pomos como possibilidade de entrar em acordo com os outros. Trata-se da linguagem na dimensão do entendimento daquilo que existe no mundo e que vale para nós e para outrem. E, por último, a categorizadora, aquela que constitui o mundo acerca do qual se pode falar ${ }^{359}$. O pensamento filosófico do século XX tem priorizado essas funções, de acordo com as diferentes abordagens desenvolvidas pelos

\footnotetext{
${ }^{359}$ Cf. G. VILAR, Prólogo, in: H.-G. GADAMER. Arte y verdad de la palabra, p. 10-1.
} 
diferentes filósofos ${ }^{360}$. Há quem ressalte uma concepção cognitiva da linguagem, tomando como paradigma o discurso da ciência; outros enfatizam nela uma forma de vida e modelo de vida ética; e há ainda aqueles que concebem a linguagem enquanto função constituidora do mundo, tomando a literatura e a retórica como sua referência de modelo.

Junto de Heidegger, Gadamer não apenas sustenta o caráter mais fundamental da linguagem em sua função categorizadora, mas também argumenta reafirmando sua prioridade com relação a suas funções cognitiva e comunicativa. Isto se justifica porque, para o hermeneuta, o que define a linguagem como linguagem não é inteligível partindo-se das formas naturais de sua comunicação, mas sim de sua determinação lingüística enquanto experiência do mundo, cujo caráter de universalidade a torna referência a todos os entes.

Em seu sentido especulativo, a linguagem constitui um centro no qual o eu e o mundo acham-se em uma unidade originária. Ao determinar-se, apresenta-se como um acontecer finito, cuja estrutura ontológico-especulativa de caráter universal consiste em um fazer vir-àfala, sob a forma de anúncio de sentido. Vir-à-fala, para Gadamer, convém esclarecer, não corresponde a uma outra existência, mas ao apresentar-se de si mesmo como expressão de seu ser. É inerente à linguagem esse processo de diferenciação de si, de modo que ser também significa representar-se (Darstellen). Cada caso de compreensão concretiza-se em um acontecer lingüístico que, por sua vez, põe a descoberto nosso comportamento em face do mundo. Se a linguagem torna-nos claro e real o próprio mundo, seu acontecimento é proporcional não apenas à permanência, mas também às mudanças das coisas às quais a condição de nossa finitude está imersa. "A linguagem não é uma criação do pensamento reflexivo, mas contribui para realizar o comportamento com respeito ao mundo em que vivemos" ${ }^{\prime 361}$. Por isso, enquanto uma experiência, constitui-se em representação do próprio mundo.

Essa relação de pertencer ao mundo pelo medium da linguagem, na medida em que torna nossa experiência de mundo essencialmente lingüística, faz, também, emergir a problemática da verdade como uma questão central da hermenêutica, haja vista, até mesmo, um âmbito de

\footnotetext{
360 "Há que se levar em conta que até aproximadamente o ano de 1960 a temática da linguagem havia em boa parte permanecido uma terra incógnita da filosofia. A partir de tal ponto a lingüisticidade impôs-se como tema dominante da filosofia [...] Essa evidência filosófica da linguagem nutriu-se de correntes muito diversas, entre elas, o positivismo lógico, a ordinary language philosophy de Oxford, o pragmatismo americano, o estruturalismo, a psicanálise, a pragmática transcendental de Apel, os últimos trabalhos de Merleau-Ponty e Heidegger. Até fins dos anos 50, eram poucos aqueles que na Alemanha tinham lido Wittgenstein. A filosofia analítica predominante na América permanecia quase invisível na Alemanha ou era associada ao Círculo de Viena, gozando por isso de má fama [...]" (J. GRONDIN, Introducción a Gadamer).

${ }^{361}$ H.-G. GADAMER, $W M$, I, p. 453.
} 
questões com as quais a própria filosofia sempre esteve bem familiarizada: a relação entre ser e verdade ${ }^{362}$. Num primeiro momento, nosso propósito não é retomar a discussão empreendida por Gadamer sobre essa relação, a partir da metafísica clássica e sua específica abordagem teórico-metodológica pela ciência moderna, mas fundamentalmente identificar como essa relação de pertencimento corresponde à experiência hermenêutica.

Pensar a partir do medium da linguagem implica que a experiência hermenêutica que se realiza entre a tradição e seu intérprete - sob a forma de uma conversação - resulte, para Gadamer, em um acontecimento decisivo: a primazia do diálogo. É importante reconsiderar a observação de que o verdadeiro acontecimento hermenêutico só se torna possível a partir da lógica hermenêutica da pergunta que converte aquele que pergunta à condição de perguntado; só acontece mediante a chegada, a escuta e o alcance da palavra que nos fala como se se referisse a nós mesmos. Do ponto de vista do sujeito, vimos que o intérprete não pode ser confundido com aquele que simplesmente extrai e busca seu objeto, depurando-o metodologicamente, para encontrar aquilo que ele realmente quer dizer. Sua consciência não possui o controle daquilo que chega até ele como palavra que vem da tradição. Do ponto de vista do objeto,

“[...] esse acontecimento significa que esse conteúdo da tradição entra em jogo e se desenvolve em possibilidades de sentido e ressonância cada vez mais novas e ampliadas de modo novo, pelo outro receptor. Quando a tradição volta a falar, emerge algo e entra em cena o que antes não era. Qualquer exemplo histórico poderia nos servir para ilustrar isso. Quer a própria tradição seja uma obra de arte, quer proporcione notícias de um grande acontecimento, em qualquer caso, o que se transmite aqui entra de novo na existência, tal como se representa" $" 363$.

Assim é que, a partir da experiência hermenêutica, o conceito de pertencimento (Zugehörigkeit) determina-se de modo inteiramente novo. Em face de todas as experiências do mundo, a experiência da linguagem remete-nos a uma dimensão em profundidade, a partir da qual a tradição, fazendo jus a sua própria significação, alcança aqueles que vivem no

\footnotetext{
${ }^{362} \mathrm{O}$ intento de Gadamer é esclarecer o caráter de constituição de finitude do fenômeno hermenêutico a partir de sua essência lingüística. A relação de pertencimento entre um intérprete e seu texto enquanto uma relação íntima passa agora a ser determinada a partir de uma experiência de mundo. Gadamer então lembra que na metafísica clássica a relação de pertencimento correspondia a uma relação transcendental entre ser e verdade. $\mathrm{O}$ conhecimento, bem antes de se constituir um comportamento do sujeito, equivalia a um momento do ser; estava incluso no ser. A verdade, em sua essência, pertence à atualidade do espírito infinito, de modo que ao pensamento humano apenas cabe, no âmbito de sua finitude, conhecer o ente. A idéia predominante não é que haja um sujeito por si capaz de converter as coisas em objetos de conhecimento, mas - como sustenta Platão um ser que se determina mediante sua participação no ser verdadeiro, uma vez que pertence a sua mesma essência. O que é nuclear, segundo a metafísica clássica, é a relação fundamental entre espírito e mudo. Isto também pode ser visto de acordo com a concepção ontológica da idéia de teleologia, segundo a qual a subordinação do meio a um fim constitui-se em um princípio adotado e adequado (cf. H.-G. GADAMER, WM, I, p. 462-3665).

${ }^{363}$ Id. Ibid., p. 466.
} 
presente e são atingidos por sua verdade. Pertencente (Zugehörig), diz Gadamer, "é aquele que é alcançado pela interpelação da tradição. Aquele que está imerso em tradições [...] tem que prestar ouvidos ao que chega a partir delas. A verdade da tradição é como o presente que está imediatamente aberto aos sentidos" $" 364$. A prerrogativa de "prestar ouvidos àquilo que chega" tem uma significação especial quando se trata de determinar mais especificamente o conceito de pertencimento. Para explicar a essência do ouvir, Gadamer retoma em Aristóteles a primazia do ouvir com relação ao ver, tendo em vista a própria universalidade do logos. Ouvir não implica apenas ser interpelado. Em sentido inverso, ao sermos interpelados por algo, somos necessariamente escuta, pois não podemos distanciar nossos ouvidos da mesma forma que nos esquivamos de algo redirecionando nossa visão para outro foco. O que confere essa superioridade em detrimento de uma limitação dos demais sentidos é que esses, uma vez restritos a seu campo específico, efetivamente participam de modo mais direto da experiência lingüística do mundo. Ao caráter universal da linguagem enquanto experiência hermenêutica do mundo, a tarefa do ouvir é fundamental, na medida em que este nos remete a uma dimensão em profundidade. Ademais, não há nada que seja acessível ao ouvido se não por meio da linguagem. "[...] o ouvir é um caminho rumo ao todo, porque está capacitado para escutar o $\log _{0 \text { o }}, 365$ Assim se cumpre a tarefa do verdadeiro ouvir, que, remontando aos tempos passados, alcança a atualidade daqueles que vivem o presente sob a predisposição de sua escuta; de ouvir o que lhes chega enquanto verdade da tradição, mesmo que sob a linguagem de mitos e lendas.

O modo de ser da tradição é linguagem, cuja compreensão dá-se pelo interpretar e pelo ouvir como expressão de um comportamento próprio e lingüístico em face do mundo. A experiência hermenêutica constitui-se, dessa forma, naquela em que o presente e a tradição, intermediados sob o acontecimento da comunicação lingüística, determinam-se como abertura de sentido e revelação de verdade. Portanto, o que torna a linguagem um verdadeiro acontecimento hermenêutico é, precisamente, aquilo que confere a esta um caráter especial, ou seja, a possibilidade de fazer vir-à-fala aquilo que foi dito na tradição, por meio da apropriação e da interpretação.

Além disso, esse movimento especulativo da linguagem de fazer vir-à-fala, em que se anuncia um todo de sentido enquanto um fazer da própria coisa, remete-nos à estrutura universal ontológica da hermenêutica gadameriana. O fenômeno hermenêutico desenvolve

\footnotetext{
${ }^{364}$ Id., ibid., p. 467

${ }^{365}$ Id., ibid., p. 466.
} 
aqui sua própria universalidade em face da constituição ôntica do compreendido; enquanto linguagem, determina-se num sentido universal ${ }^{366}$ como linguagem, e, enquanto interpretação, ressalta sua própria referência ao ente.

Do ponto de vista especulativo, é esse movimento de vir-à-fala o que Gadamer tem em vista, inicialmente, quando desenvolveu uma crítica à consciência estética em benefício de uma de análise sobre a experiência hermenêutica. Ao reconhecer a linguagem como medium universal de especulação hermenêutica, a reflexão sobre a arte, por um lado, constitui-se num ponto de partida concreto de análise e num questionamento hermenêutico universal, e, por outro, retoma a problemática da arte e sua verdade. Se uma reflexão hermenêutica sobre o fenômeno artístico pressupõe a necessidade de tomá-lo como fenômeno hermenêutico, a experiência hermenêutica de sua verdade pressupõe também uma relação de pertencimento fundamental entre arte, linguagem e verdade. Como, então, pensar a questão da verdade da arte a partir da linguagem? Como pensar a verdade da arte enquanto configuração essencialmente lingüística? Como pensar a verdade da arte a partir do caráter de sua atualidade no tempo; enquanto um movimento de fazer vir-à-fala pleno de sentido?

Quando Gadamer refere-se ao modo de ser da arte como representação (Darstellung), recuperando o conceito de mimesis, no sentido de conhecimento ou mesmo de reconhecimento, busca mostrar que a arte enquanto Gebilde, representada em seu jogo, é a verdade duradoura. É um mundo no qual o jogo vem à fala enquanto pura realização, energeia, trazendo em si seu próprio telos. Sua verdade justifica-se porque ela dá-nos a conhecer e reconhecer algo, bem como a nós mesmos. Por isso, "o ser da representação é mais do que o ser da matéria representada, o Aquiles de Homero mais do que seu modelo original ${ }^{\not 367}$. Do ponto de vista hermenêutico, esse ideal representado, no qual identificamos mais do que aquilo que é conhecido, constitui-se em seu horizonte de sentido. Ora, isso conduz Gadamer à filosofia platônica da anamnesis, sua compreensão da dialética de busca do saber, de busca da verdade do ser na idealidade da linguagem, nos logói. Na verdade, a pretensão de Platão, pensa Gadamer, é mostrar que na linguagem não se pode alcançar nenhuma verdade pautada na coisa, e o que abre acesso a ela, de fato, não é a palavra. Isso aponta o sentido e a direção de buscar entender a verdade a partir da linguagem. Assim, antes

\footnotetext{
${ }^{366}$ No tocante ao caráter de universalidade conferido á hermeneutica por Gadamer, estabelece-se uma grande polêmica entre Gadamer e Habermas. Para esse último, gadamer desconsidera as experiências extralingüísticas do mundo como o poder e o trabalho. Segundo habermas o acordo lingüístico pensado por Gadamer limita-se a um círculo fechado.

${ }^{367}$ Id., ibid., p. 120
} 
de retomarmos a especificidade da verdade a partir do ser da obra de arte no horizonte de seus desdobramentos, torna-se necessário identificarmos o que significa a verdade para Gadamer.

Segundo Gadamer a questão da verdade remete-nos ao sentido mesmo de sua pergunta sobre ela. Ao perguntar-se por ela, tal como em “O que é a verdade?" (Was ist Wahrheit?), de 1957, ele o faz recorrendo a uma passagem bíblica. Refere-se ao Evangelho de São João, em uma passagem em que é narrado o encontro de Jesus com Pôncio Pilatos. Diante da pergunta do governador Pilatos, "o que é a verdade?", Jesus responde: "É para dar testemunho da verdade que nasci e vim ao mundo. Todo o que é da verdade ouve a minha voz" (Jo, 18,38). Segue-se um lavar as mãos e a autorização do veredicto de condenar um réu.

Segundo Gadamer, o que há de importante nessa pergunta é precisamente a questão de sentido à qual ela nos envia, bem como o fato de ainda continuar determinando a vida humana. Trata-se de uma pergunta de caráter universal, que pode ser elaborada diante das mais diversas situações. O que confere sentido a essa pergunta é, em primeiro lugar, a não conformidade ou mesmo reação diante de um dogmatismo, ou mesmo de um fanatismo de qualquer gênero. Uma repulsa cética diante dos fanáticos, no modo com que Nietzsche, lembrado aqui por Gadamer, incisiva e criticamente o fez à tradição. Mas como bem percebe Gadamer, a crítica nietzschiana também se estende à ciência, na medida em que entre ela e o fanático a intolerância enquanto sintoma de fraqueza surge como algo em comum. Diz Gadamer: "Ninguém é mais intolerante do que aquele que quer comprovar que aquilo que ele diz deve ser a verdade" ${ }^{368}$. Ora, a partir daqui se inicia o contraponto à questão em que nos situamos. A análise sobre a questão da verdade aponta para sua relação com a linguagem e com a ciência. A pergunta pela verdade determina-se agora como um questionamento sobre a pretensão do saber científico enquanto único suporte de verdade. Para Gadamer, embora a ciência seja responsável pela libertação de muitos preconceitos, quanto mais se amplia o caráter de seu procedimento metodológico mais se torna limitado o alcance de sua verdade. Desse modo, quais são os limites de seu procedimento metodológico? O problema é que, ao delimitar o que pode ser conhecido cientificamente, a ciência impõe um distanciamento de questões necessárias a serem pensadas, analisadas, qualificando-as de absurdas, sem sentido. Trata-se, na verdade, de questões que não se submetem a seu critério de comprovação e verdade. Esse âmbito de questões no qual se insere a filosofia constitui a posição do cético diante da ciência, desacreditando-a como única instância portadora de verdade.

\footnotetext{
${ }^{368}$ H.-G. GADAMER, “Was ist Wahrheit?”, in: Gesammelte Werke, Vol. 2, p. 44.
} 
$\mathrm{Na}$ medida em que a arte fora afirmada, anteriormente, como reivindicação de verdade sob a forma de uma advertência à consciência científica, o momento agora é de, tomando como ponto de partida a questão da verdade, buscar justificar o que fundamenta essa afirmação que confere elevada dignidade à experiência da arte. $\mathrm{O}$ que legitima uma relação tão privilegiada entre a verdade e a ciência, em detrimento das demais instâncias de conhecimento, até mesmo a arte?

Examinar essa questão implica voltar-se às origens da ciência. $\mathrm{O}$ procedimento de remeter-se às origens é necessariamente acionado pela hermenêutica, sobretudo como exercício de demonstração do caráter historicamente condicionado do conhecimento. Remontar a suas raízes é, no caso, dirigir-se a sua origem grega. Sua elaboração assumiu um diferencial no tocante ao cultivo do saber. O ímpeto investigativo pelo estranho, desconhecido e maravilhoso, orientou a ciência grega por um outro caminho, diferente daquele escolhido no Oriente. O espírito científico grego, segundo Gadamer, revela, desde cedo, ceticismo, marca de pensamento que foi responsável pela criação da própria ciência, dada a sua sede pelo conhecimento e ânsia pela verdade ${ }^{369}$.

Ao longo de sua análise, Gadamer observa que a concepção da ciência moderna, embora herdeira da ciência grega, distanciou-se bastante de sua significação original. Em sua recuperação heideggeriana, é a própria significação da palavra verdade (aletheia), ao designar um movimento de ocultação e desocultação, que elucida essa questão. Ocorre que a significação do ocultar corresponde também à ação discursiva dos homens. E, se pelo discurso, que não transmite apenas verdade, podemos ser conduzidos à ilusão e ao engano, passa a subsistir uma relação entre ser e discurso: "a desocultação do ente vem à fala no desvelamento da proposição" ${ }^{370}$. Mas as coisas estarem veladas no discurso é algo que se dá porque sua razão de ser assim permite que elas sejam apresentadas. Daí resulta a identificação de logos com razão. Desse raciocínio resulta a concepção de discurso como enunciado ou juízo - aphophansis. Em seu sentido de desocultação, seu mérito radicaliza-se não mais no sentido de mostrar o ente tal como ele é, mas enquanto pretensão exclusiva de revelá-lo em sua verdade. A verdade restringiu-se a sua demonstração discursiva. Como diz Aristóteles, citado por Gadamer: "Um juízo é verdadeiro quando deixa e propõe uma reunião daquilo que está reunido na coisa; um juízo é falso quando deixa e propõe uma reunião no discurso

\footnotetext{
${ }^{369}$ Cf. H.-G. GADAMER, “Was ist Wahrheit?”, in: Gesammelte Werke, Vol. 2, p. 47.

${ }^{370}$ Id., ibid., p. 48.
} 
daquilo que não está reunido na coisa"371. Daí resulta a concepção de verdade como veritas est adaequatio intellectus ad rem, ou seja, a verdade como adequação do discurso à coisa: verdade enquanto possibilidade de dizer aquilo que mostra exatamente como as coisas são.

O ideal platônico de encontrar a verdade nos lógoi vai sendo substituído por uma busca de verdade baseada exclusivamente na demonstração discursiva. Da teoria grega do logos Aristóteles derivou como lugar da verdade simplesmente o juízo. Baseada nessa compreensão de verdade enunciativa, ressalta Gadamer, desenvolveu-se toda a teoria científica moderna. Ela, mesmo na condição de herdeira, em muito se afastou de suas origens, de modo que sua sustentação tornou-se metodológica.

\begin{abstract}
“Methodus significa 'caminho para ir em busca de algo'. O metódico é poder recorrer de novo o caminho andado, e tal é o modo de proceder da ciência. Mesmo isso pressupõe necessariamente uma restrição nas pretensões de alcançar a verdade. Se a verdade [veritas] supõe a verificabilidade - de uma ou outra forma -, o critério que mede o conhecimento não é já sua verdade, mas sim sua certeza. Por isso, desde a formulação clássica dos princípios de certeza de Descartes, o verdadeiro ethos da ciência moderna passou a ser o fato de que ela só admite como satisfazendo as condições de verdade, o que satisfaz o ideal de certeza" ${ }^{372}$.
\end{abstract}

O que garante o ideal de conhecimento é o método, esse caminho que pode ser refeito em busca de verificabilidade e confirmações e que pode ser seguido. Por esse procedimento, a ciência moderna, desde Descartes, garantiu a pretensão de uma verdade enunciativa.

Desse modo, tendo o esclarecimento da pergunta pela verdade como contraponto a ciência, isto se dá precisamente com o objetivo de questionar seus limites. Sob o critério de seu ideal de verificação, a ciência, embora restrinja o saber, determina-se em todos os âmbitos da vida.

Heidegger, lembra Gadamer, orientado por essa questão, reconheceu a limitação desse caminho assegurado pela verdade, bem como de sua significação . Ao verificar o significado de aletheia, ele nos faz perceber o que significa para a concepção de ser essa retirada da verdade de seu estado de ocultação. Por isso em Ser e tempo sua analítica do Dasein desenvolve-se sob o horizonte de uma ontologia fundamental, identificando no ser humano uma abertura ontológica. Na medida em que seu modo de ser é definido como finitude, isso também se dá na condição de que ele é um ser-para-a-morte. Mas, se, como diz Gadamer, "o encobrimento [Verborgenheit] é próprio da ação da linguagem humana [...] a desocultação [Unverhohlenheit] do ente produz-se na afirmação [Aussage] da linguagem,"373. Com efeito,

${ }^{371}$ H.-G. GADAMER, “Was ist Wahrheit?”, in: Gesammelte Werke, Vol. 2, p. 48.

${ }^{372}$ Id., ibid.

${ }^{373}$ Id., ibid., p. 46. 
quando Heidegger indaga pelo sentido do ser, o que ele sustenta é o próprio sentido da pergunta pela verdade, cuja primazia sempre se impõe diante de suas possíveis respostas. "Só a pergunta de Heidegger pela essência da verdade transcendeu realmente o âmbito da subjetividade. Seu pensamento percorreu desde o 'útil', passando pela 'obra', até a coisa, um percurso que deixa muito atrás a questão da ciência, inclusive das ciências históricas. É hora de não esquecer que a historicidade do ser continua presente quando o Dasein conhece-se a si mesmo e comporta-se historicamente como ciência"374. Perante a radicalização pela ciência moderna dos pressupostos decisivos para a compreensão do logos grego, delimitando a verdade ao âmbito lógico do enunciado, é a investigação fenomenológica, diz Gadamer, que vai investigar e denunciar a pretensão de um enunciado verdadeiro e absoluto. Naquele propósito, a verdade de um enunciado é apreendida desconsiderando-se a motivação de seus pressupostos, a pressuposição de seu horizonte de sentido, até mesmo a forma lógica da pergunta, caráter essencial do diálogo platônico e da dialética grega.

Diante dessa argumentação, Gadamer busca no caráter hermenêutico universal da linguagem a possibilidade de ultrapassar a dimensão apofântica dos enunciados. A partir da concepção heideggeriana de aletheia - a verdade como desocultamento -, Gadamer sustenta que, em sua função constituidora do mundo, a linguagem abre-nos à verdade, a verdade como fundação de sentido, daquilo que, independentemente de ser verdadeiro ou falso, não equivale a ela em sua significação enquanto correspondência - verdade no sentido tradicional de adequatio rei et intellectus.

Nesse sentido não podemos deixar de mencionar a solidez e o rigor da reflexão heideggeriana intitulada Sobre a essência da verdade (Von Wesen der Wahrheit, 1943) proferida desde 1930. Perguntar pela essência da verdade nos remete não apenas a identificar o que de fato a caracteriza como tal, como também revela uma indagação crítica sobre o seu sentido e o lugar - contexto - de onde emerge essa pergunta. Eis para Heidegger o que justifica a necessidade desse questionamento. Do ponto de vista ordinário a afirmação da verdade implica o estado de acordo, seja a concordância entre uma coisa e o que realmente pensamos dela, seja a conformidade entre aquela e o que significa sua enunciação. "Veritas est adequatio rei et intellectus, [...] Verdade é a adequação da coisa com o conhecimento. Mas pode se entender também assim: Verdade é a adequação do conhecimento com a coisa. Ordinariamente a mencionada definição é apresentada pela fórmula veritas est adequatio intellectus ad rem [...] Estas duas concepções da essência da veritas significam um

${ }^{374}$ Id., ibid., p. 54. 
conformar-se com... e pensam, assim a verdade como conformidade ${ }^{375}$. Para Heidegger, no entanto a redução da verdade da proposição à verdade da coisa não é suficiente para precisarmos sua essência . Ora, se é a idéia de concordância que a estabelece, é com base na elucidação de uma concepção antiga do pensamento qual seja: a concordância da enunciação (logos) com o seu objeto que a questão passa a ser examinada. O problema é que se a enunciação sempre difere, essencialmente da coisa, como entender a possibilidade de uma adequação entre ambas ? Enquanto essência da verdade, isto só se torna possível mediante aquilo que Heidegger denomina de "enuciação apresentativa". Enunciar é, senão o apresentar, "[...] o deixar surgir a coisa diante de nós como objeto"376. A enunciação ao exprimir aquilo que é e se apresenta, realiza-se sob a forma de uma abertura orientada para o objeto e em busca de uma conformidade com ele. É precisamente essa compreensão "de deixar ser aquilo que está presente"- o ente - como é, do jeito que é, que faz da liberdade o fundamento da conformidade e da essência da verdade. Essa noção de "uma abertura que permanece" é o que sustenta a possibilidade de uma resignificação do conceito de verdade enquanto aletheia, desvelamento - ta aléthea -, cujo sentido é oriundo dos primórdios dopensamento ocidental. Por isso, " a verdade não é mais a característica de uma proposição conforme, enunciada por um 'sujeito' relativamente a um 'objeto' e que então 'vale' não se sabe em que âmbito; a verdade é o desvelamento do ente graças ao qual se realiza uma abertura. Em seu âmbito se desenvolve, expondo-se, todo o comportamento, toda tomada de posição do homem" ${ }^{\text {377 }}$. Porém, da mesma forma que a verdade constitui-se como o velar que ilumina e desencobre, ela também corresponde à dissimulação (Verstellen), o velamento como recusa e retração. O que torna autêntica a questão da essência da verdade é a noção de velamento do ente, essa dissimulação primeira, a não-verdade original que pressupõe todo deixar-se desvelar. Essa amplitude do significado de aletheia é, conforme também vimos anteriormente desenvolvida em sua conferências proferidas em 1936 denominada $A$ origem da obra de arte.Aí, a noção de clareira (Lichtung) aparece diretamente associada á noção do acontecer (Geschehen), do deixar acontecer a verdade enquanto unidade do movimento de abertura e ocultação. O que está encoberto e dissimulado precisa ser iluminado, o que só se torna possível mediante a ek-sistência do homem, mediante a sua inserção (Sicheinlassen) que lhe permite ek-sistir como um ser que pergunta e desvela. É a desocultação do ente que nos determina

\footnotetext{
${ }^{375}$ M. HEIDEGGER, Sobre a essência da verdade, p.133.

${ }^{376}$ Id.,ibid., p. 135

${ }^{377}$ Id., ibid., p. 138
} 
Evidentemente que também baseado nessas reflexões ontológicas, nos diz Gadamer:

\begin{abstract}
"Não há nenhum enunciado que se possa entender unicamente pelo conteúdo que propõe, se se quer compreendê-lo em sua verdade. Cada enunciado tem sua motivação. Cada enunciado tem uns pressupostos que ele não enuncia [...] Afirmo que a última forma lógica dessa motivação de todo enunciado é a pergunta. Não é o juízo, mas a pergunta que tem prioridade na lógica, como confirmam historicamente o diálogo platônico e a origem dialética da lógica grega [...] não há nenhum enunciado que não seja fundamentalmente uma resposta. Por isso, a compreensão de um enunciado tem com única norma suprema a compreensão da pergunta a que responde" ${ }^{378}$.
\end{abstract}

Partindo do pressuposto de que o horizonte da linguagem apresenta-se como via de um redirecionamento para se pensar a questão da verdade, isso se determina, necessariamente, como recuperação da dialética da pergunta e da resposta assumida pela hermenêutica. É enquanto possibilidade de pergunta, a viabilizar, até mesmo os pré-juízos então assimilados, que o domínio da investigação científica precisa ser revisto.

Correspondendo a pergunta pelo sentido do ser à mesma raiz que a indagação pela verdade, sua resposta remete-nos ao âmbito universal, marcada pela amplitude originária da própria pergunta. O que precisa fica claro, do ponto de vista hermenêutico, é o seguinte: apenas tendo em vista a primazia da pergunta é que se realiza a desocultação (Unverbogenheit) da verdade como um processo contínuo. À pergunta pertence a predisposição e um interpelar constante, enquanto à verdade é inerente esse movimento de velamento-desvelamento. Se, como diz Platão, "privar-nos da linguagem é privar-nos do próprio ser", a verdade também não pode ser dita sem o procedimento da interpelação (Anrede), de onde decorrem respostas, ou mesmo um acordo. A verdade enquanto interpelação atualiza-se na linguagem, no movimento que nos remete sempre a um novo perguntar. Se a verdade que decorre de nosso processo de compreensão apresenta um caráter essencialmente histórico, no qual está situada, aquilo que sua pergunta obtém como enunciado e resposta constitui-se como expressão de nossa finitude.

Assim, o propósito de Gadamer ao explicitar a pergunta "o que é a verdade?" constituise em pensá-la não apenas por uma via ontológica, mas sob o rigor crítico-hermenêutico de sua pretensão no âmbito da ciência. Reconsiderá-la como aletheia mediante a análise pontual heideggeriana significa que a densidade de seu questionamento da verdade não pode prescindir da noção de abertura originária própria do ser, a sua estrutura prévia de linguagem, pela qual os entes se pronunciam e vêm-à-fala.

\footnotetext{
${ }^{378}$ H.-G. GADAMER, “Was ist Wahrheit?”, in: Gesammelte Werke, Vol. 2, p. 52.
} 
Como ressaltamos anteriormente, uma análise hermenêutica do fenômeno da arte apresenta como mérito a retomada da questão da verdade da arte, e essa afirmação parece encontrar aqui sua legitimidade. Todo procedimento de explicitação ontológico-hermenêutico sobre o modo de ser da obra de arte desenvolveu-se sob a exigência de demonstração da experiência da arte como uma experiência de reivindicação de verdade, para além da exclusividade metodológica da ciência. Além disto, torna-se fundamental legitimar esta proposta gadameriana não apenas considerando a crítica e os limites identificados por Gadamer no acesso da ciência à verdade, mas fundamentalmente, registrando a significação ontológica que o conceito de verdade assume como um dos fundamentos de sua hermenêutica

O que torna a experiência da arte um fenômeno hermenêutico paradigmático é ter nela se enraizado uma experiência de finitude fundamental de nosso ser. Enquanto modo de ser, é experiência de abertura e negatividade, que nos interpela diante de nós mesmos; enquanto presença declarativa,é uma abertura a interpretações dinamizada pela intermediação da consciência histórico-efeitual.

Mas, quando se trata de pensar o caráter de sua verdade pela natureza de sua presença histórico-temporal, há na análise de Gadamer uma formulação histórico-filosófica sobre a arte com a qual sua hermenêutica dialoga ainda de modo curioso. Trata-se de pensar a presença declarativa da arte, também, a partir da reflexão estética hegeliana.

\subsection{Atualidade do belo: um diálogo entre Gadamer e Hegel}

Além de não podermos prescindir da anterioridade da linguagem para explicitar a questão da verdade na arte, convém advertir que a indagação hermenêutica sobre o que é a experiência da arte em sua verdade conduz-nos a antecedentes fundamentais acerca dessa problemática. A primazia dessa questão, ao ser abordada na primeira parte de Verdade e método, consolida-se graças à crítica desenvolvida por Gadamer da noção de consciência estética. Para a experiência da arte em obra, o que importa não é simplesmente aquilo que a consciência pensa como experiência de suas vivências, nem tampouco ser apreendida como esfera de encantamento e prazer subjetivo destituído do estatuto de verdade. Desse modo, fazer justiça à experiência da arte é predispor-se a compreendê-la como verdade que vem a nosso encontro, e, diante disso, não podemos prescindir do diálogo do hermeneuta com a estética hegeliana, cuja diretiva fundamental afirma categoricamente a arte como manifestação sensível da 
verdade. O que torna fértil o diálogo de Gadamer com Hegel não é apenas o fato de ambos sustentarem a tese da arte como experiência de verdade, mas o próprio viés histórico-dialético que intermedeia essa formulação e que possibilita entre ambos a existência de um verdadeiro ajuste de contas. Na qualidade de uma experiência hermenêutica histórica, nosso intento é identificar na produtividade de seu próprio conhecimento histórico uma formulação que também assegure o caráter fundamental de atualidade. Nesse sentido, a compreensão hermenêutica da arte como declaração de verdade parece encontrar na estética hegeliana um contraponto especial.

Em decorrência dos resultados obtidos a partir da crítica à consciência estética, Gadamer advertiu-nos de que a idéia de verdade na esfera do conhecimento não podia mais ser mensurada, como pensava Kant, pelo conceito de conhecimento da ciência e pelo conceito de realidade pertinente às ciências da natureza. A necessidade de reconsiderar e ampliar o conceito de experiência permitia então entender a experiência da obra de arte. Conforme menciona Gadamer, foi mérito da estética hegeliana reconhecer o conteúdo de verdade expresso nas determinações artísticas e transmitido enquanto consciência histórica. Hegel, ao cumprir a tarefa de "[...] justificar na própria experiência da arte o conhecimento de verdade $^{\text {„379, }}$, torna também a estética uma história da verdade refletida nas configurações artísticas.

Ao proceder a uma análise crítica sobre o caráter de subjetivação da estética, reconsiderando o testemunho da experiência estética, Gadamer dá um primeiro e decisivo passo no desenvolvimento de uma reflexão hermenêutica sobre a arte em sua relação com a verdade. O questionamento com respeito a sua verdade tem, todavia, como foco de interlocução não apenas Heidegger, com quem dialogou especificamente sobre essa questão, mas também as preleções sobre a estética hegeliana, com a qual discute e discorda, mas à qual se filia em algumas de suas diretivas.

Identificar algumas dessas limitações e insuficiência não significa apenas reduzir a crítica do hermeneuta a uma crítica ao idealismo. Assim, torna-se necessário um exame mais direto sobre esse diálogo.

Já no início das Lições de estética (Vorlesungen über die Ästhetik), de 1835, Hegel propõe-se a refletir sobre a arte de modo lemático, haja vista que pensar qualquer que seja o objeto sob o rigor filosófico é ter clareza e conviçção da impossibilidade de invocar

\footnotetext{
$\overline{{ }^{379} \text { H.-G. GADAMER, } W M, \text { I, p. } 170}$.
} 
representações a partir de princípios que não resultem de uma elaboração que lhe anteceda. Abordar o fenômeno artístico sob o caráter fundamental do pensar filosófico implica, necessariamente, pensá-lo mediante o "esforço conceitual",380, considerando-o na intimidade de seu conceito, na expressão e dinâmica de sua necessidade interior. Ora, isso significa que a filosofia da arte, enquanto uma particularização do universal, só pode ser compreendida pressupondo-se, como diz o próprio Hegel, o elo necessário que esta forma no conjunto da filosofia, ou seja, como um momento de articulação do Absoluto ${ }^{381}$ (Absolut) em sua totalidade sistêmica. É somente na recondução à unidade que a unilateralidade é ultrapassada como absolutização de um momento e a razão (Vernunft) reconhecida como seu fundamento; apenas enquanto um momento do todo, um conteúdo encontra sua justificação, do contrário, não passa de certeza subjetiva ou mesmo de um pensamento infundado. O que garante a condição de verdade à arte é, pois, sua fundamentação científica, sua indispensável referência espiritual.

Assim, do ponto de vista do desenvolvimento enciclopédico da filosofia, numa primeira divisão a ciência divide-se em lógica, filosofia da natureza e filosofia do espírito, e é precisamente na esfera desta última que a arte apresenta-se como verdadeiro momento de particularização espiritual. É, entretanto, apenas enquanto manifestação do Espírito absoluto, verdadeiro existente em si e para si, que a arte mostra-se sob a forma de um saber direto e sensível. Mesmo considerada como um momento de finitude, a arte é concebida por Hegel não como esfera do espírito subjetivo e objetivo, mas como "[...] a intuição concreta e a representação do espírito absoluto em si como ideal - da figura concreta nascida do espírito subjetivo, na qual a imediatidade natural é apenas sinal da idéia, para cuja expressão ela é de tal modo transfigurada pelo espírito plasmador que a figura nada mais mostra nela",382.

\footnotetext{
380 A expressão "esforço conceitual" ou "esforço tenso do conceito" é usada por Hegel no Prefácio à Fenomenologia do espirito, quando então ressalta uma exigência atenciosa ao conceito para o estudo da ciência. Para tanto, no propósito de elucidar seu mundo conceitual tanto em sua natureza própria quanto na dinâmica de seu auto-movimento, Hegel registra uma diferenciação entre o "pensamento que raciocina" e o "pensamento conceitual". A esse respeito, vale ressaltar a leitura feita por Nicolai Hartmann (N. HARTMANN, A filosofia do idealismo alemão, p. 296-301).

${ }^{381}$ Segundo Hegel, a noção de Absoluto não se refere a algo subjacente ao mundo fenomênico, mas corresponde a um sistema conceptual nele inserido, cuja natureza não é estática, já que se manifesta na natureza, reconhece-se no próprio conhecimento humano e atinge o máximo de sua realização na filosofia. O Absoluto é movimento dialético de autodesdobramento na história, diferenciação submetida a mediações que se suprassumem em vista de um nível superior de idealidade. Diz Hegel: "O espírito absoluto é eternamente em si, como a si deve retornar e já retornou; é a única e universal substância como substância espiritual, a divisão [o juízo] em si e num saber para o qual ela é como substância" (G.W.F. HEGEL, Enciclopédia das ciências filosóficas em epítome, Vol. III, p. 165 ).
} 
Diante do exposto, na leitura de Gadamer o reconhecimento da verdade da arte por Hegel é conseqüência do fato de seu idealismo ter sobrepujado seu pensamento com o saber conceitual da filosofia, embora o momento de verdade da arte represente um momento de ultrapassagem do âmbito do espírito. Como nos diz Hegel mesmo, no processo de atingir o verdadeiro conceito de sua essência absoluta, o espírito percorre graus que o próprio conceito lhe impõe. O Espírito (Geist), convém lembrar, é autodesenvolvimento dialético que, no cumprimento de sua exigência conceitual, submete-se ao destino de sua própria finitude, determinando-se na exterioridade imediata sob o domínio de sua presença sensível - a arte. O problema é que, embora a arte seja definida pelo idealismo estético hegeliano como apresentação (Darstellung) necessária da idéia particularizada no seio da finitude sensível, sua determinação enquanto esfera de realização efetiva do Absoluto (Absolut) ${ }^{383}$ é também marcada por sua limitação. Pois, "se a arte serve para tornar o espírito consciente de seus interesses, não constitui o modo mais elevado de expressão da verdade. [...] a arte, até pelo seu conteúdo, encerra-se em certos limites, que atua sobre sensível e, portanto, apenas tem por conteúdo um determinado grau de verdade ${ }^{\$ 84}$. Para Hegel, o que confere o grau de limitação da arte enquanto expressão ideal é, precisamente, sua exposição sensível, já que “[...] a existência sensível quer dizer tão-somente o ser fora de si do conceito, do conceito que se perde na confusão e transitoriedade da aparência" ${ }^{385}$. Tal limitação decorre do sensível, já que este esconde, macula o verdadeiro, não permitindo a explicitação da unidade universal do Absoluto. Desse modo, no suposto de que a infinitude não pode existir sem a finitude, a arte como verdadeiro domínio dessa realização, ao incluir sua indispensável ligação com o sensível, é consignada a um grau inferior na escala ontológica de efetivação do Absoluto, abaixo da religião e da filosofia. Torna-se ainda relevante percebermos que, embora Hegel confira à arte um tratamento científico-racional, esta, como obra da razão (Vernunft), apresenta seu inegável limite não pelo fato de suas criações conterem elementos de ordem irracional ou mesmo reduzirem-se a uma significação de sentimentos, mas pelo fato de encontrar-se entretecida ao sensível. O significado material e alegórico das representações artísticas obscurece a verdade em seu nível de transparência.

\footnotetext{
${ }^{383}$ Segundo o idealismo hegeliano, três são as formas de realização efetiva do Absoluto: a arte, a religião e a filosofia. Justificá-las para Gadamer só é possível a partir dessa "[...] primazia do pleno autoconhecimento do espírito que permitiu a Hegel compreender essas formas como formas do espírito absoluto. Nelas já não havia nada de estranho, e, por isso, o espírito estaria inteiramente em casa, estando consigo mesmo" (H.-G. GADAMER, $W M$, I, p. 350).

${ }^{384}$ G.W.F. HEGEL, Cursos de Estética, Vol. 1, p. 143

${ }^{385}$ Id., Enciclopédia das ciências filosóficas em epitome, Vol. 1, p. 162.
} 
Gadamer atenta ao fato de que, mesmo a arte constituindo-se como momento de verdade permanente que ultrapassa o campo subjetivo, a verdade do conceito, como é pensada pela filosofia de Hegel, desautoriza esse caminho da verdade outrora reconhecido na experiência da arte. Assim, não basta que arte seja abordada como esfera de verdade, limitada ao conceito de sua manifestação e experiência, já que é necessário que a própria razão retome o caminho de sua verdade. Por isso, podemos dizer que, por um lado, a estética hegeliana apresenta o mérito de superar o subjetivismo da consciência estética fundamentado por Kant, ampliando, conseqüentemente, o campo de determinação da verdade às esferas das manifestações espirituais, mas, por outro, fixa como seu ponto de partida o Absoluto (Absolut). A partir do desdobramento dialético do saber infinito, embora a esfera da finitude seja reconhecida como região de verdade, ela ao mesmo tempo encerra em si a subsunção da arte na filosofia.

O problema da arte, ao ser submetido ao problema de sua verdade, reflete, desse modo, a indagação sobre o que constitui a significação do belo artístico, diante de suas expressões mais específicas e simultaneamente mais diversas. Quando Hegel define o belo artístico como "manifestação sensível da Idéia", isto significa que, diante do belo, a Idéia torna-se presente em sua verdade. No entender de Gadamer, o que há de significativo na experiência do belo artístico é a totalidade do mundo experienciado, na medida em que nesse encontro a posição ontológica do humano no mundo revela sua finitude diante da transcendência. Dito de outra forma, isso significa que o que há de mais especial e autêntico nessa experiência é o fato de a obra falar-nos como obra, e não, conforme pensava a convicção norteadora da estética hegeliana, como transmissora de uma verdade.

\footnotetext{
"A expectativa de que o conteúdo de sentido que nos fala como arte possa ser buscado no conceito sempre ultrapassou a arte de um modo muito perigoso [...] Temos interpretado isso como uma afirmação de princípio hegeliano, desde que na forma do conceito e da filosofia pode-se e deve-se buscar tudo o que nos interpela de modo obscuro e não conceitual na linguagem sensível e particular da arte ${ }^{\$ 386}$.
}

A compreensão da experiência do belo artístico proferida pela estética de Hegel constituise assim, sustenta Gadamer, muito mais em um descaminho, configurado na sedução idealista, tanto relativa à experiência histórica passada da arte quanto a sua experiência moderna. Por experiência moderna da arte, Gadamer refere-se aos movimentos da arte emergidos a partir do século XIX, que, por sua vez, não criam em nós, espectadores, qualquer expectativa de orientação de sentido ou mesmo de poder ser compreendida na forma de um conceito.

\footnotetext{
${ }^{386}$ H.-G. GADAMER, Aksch., p. 86-7.
} 
Por isso, se somos inclinados a precisar o sentido da obra de arte, este se determinaria muito mais pelo caráter presencial de seu acontecimento enquanto produto que, de quando em quando, submete-nos a um jogo de contrários, de manifestação e ocultação, do que como um simples suporte de sentidos. "Em seu caráter insubstituível, a obra de arte não é um mero portador de sentido, como se esse sentido pudesse ser carregado por outros portadores. De preferência, o sentido de uma obra de arte consiste em ela estar aí” ${ }^{\prime 37}$.

De fato, a reflexão sobre o sentido da arte está diretamente ligada à problemática de sua verdade. Se, nas considerações hermenêuticas de Gadamer, a arte não corresponde a uma simples abertura de sentido, isto se dá exatamente tendo em vista a superação heideggeriana do conceito de sentido inerente ao idealismo hegeliano. A ponderação hegeliana de uma expectativa de sentido revelada pela arte resultou insatisfatória diante do passo reflexivo dado por Heidegger, quando então se refere à plenitude ontológica ou mesmo à verdade (aletheia) que nos fala, a partir da obra de arte, sob a forma de um processo de velamento desvelamento. Com essa visão, rompem-se os limites de uma pura integração de sentido, haja vista que, em sua experiência, nela o sentido está fixo e protegido em sua estrutura de criação. $\mathrm{Na}$ arte, o sentido não se revela simplesmente, mas está acumulado, tornando-se, assim, um "abrigo de sentido" em algo fixo.

A verdade da arte naquilo que nela vem à representação constitui-se em experiência de reconhecimento, já que nela subsiste um sentido a partir do qual nela nos movemos e permanecemos. Mas não se trata de uma simples mediação ou transmissão de sentido, restrita apenas a um grau de determinação de verdade, adverte Gadamer. Sua afirmação torna-se enfática:

\footnotetext{
"Enquanto se definir - com os idealistas, por exemplo, com Hegel - o belo da arte como a manifestação sensível da idéia, em si uma retomada genial dos acenos platônicos sobre a unidade do bom e do belo, pressupor-se-á necessariamente que é possível ir além desse modo de aparecer do verdadeiro e que o pensado filosoficamente na Idéia é justamente a forma mais alta e adequada de apreender essas verdades. Pareceu-nos ser erro e fraqueza de uma estética idealista o fato de ela não ver que justamente o encontro com o particular e com a manifestação do verdadeiro só tem lugar na particularização, na qual se produz esse caráter distintivo que a arte tem para nós e jamais superável" ${ }^{\text {"388 }}$.
}

Para Gadamer, realmente a idealidade da obra de arte não pode ser determinada por meio da relação com uma idéia, conforme assinala Hegel, como o aparecer da Idéia. De modo contrário, uma reflexão hermenêutico-filosófica sobre a arte, ao definir sua investigação sob o caráter essencial ontológico, toma como ponto de partida a finitude, e não um saber absoluto.

\footnotetext{
${ }^{387}$ H.-G. GADAMER, Aksch., p. 87.

| ${ }^{388}$ Id., ibid.,p. 94.
} 
Uma configuração plástica, uma peça poética ou musical guarda sempre uma relação indissolúvel com seu mundo.

Considerando-se a argumentação inicial de nossa pesquisa, a estética, ao ser subordinada à hermenêutica, implica, conforme Gadamer, uma reconsideração justa sobre a experiência da arte, recuperando-a sob o primado da verdade. Essa compreensão, na medida em que implica uma mediação histórica, promove também uma discussão sobre a atualidade de seu sentido e, conseqüentemente, sobre sua manifestação de verdade. Gadamer então dialoga com Hegel, a partir da reflexão hermenêutica de Schleiermacher, sobre a determinação original da obra de arte. Advindas do passado, no qual estão enraizadas em seu mundo original, as obras de arte estão sentenciadas a perder seu significado original, uma vez retiradas desse seu solo e submetidas à circulação. Se elas pertencem essencialmente a seu mundo, declara Gadamer interpretando o hermeneuta, e se "[...] somente este é que poderá determinar plenamente seu significado, parece que se há de concluir que o verdadeiro significado da obra de arte só se pode compreender a partir deste mundo, portanto, a partir de sua origem e de seu surgimento" ${ }^{389}$. É o saber histórico, enquanto caminho de reconstituição da tradição e reconstrução ${ }^{390}$ das condições originais, que mantém a salvo o verdadeiro significado da obra de arte, protegendo-a de falsas atualizações ${ }^{391}$. Ora, tendo essa concepção como referência a consciência de uma perda diante da tradição, segundo Gadamer, essa hipótese de reconstituição originária do passado em face do caráter de historicidade nos é inteiramente insuficiente.

É Hegel quem, todavia, sugere uma possibilidade diferente de pensar o significado verdadeiro da arte a partir da mediação e conservação histórica. Quando Hegel ressalta a afirmação de que "existem obras de arte" como ponto de vista desde o qual devemos situarnos para o tratamento científico da arte, ele parece também querer dizer que uma reflexão de tal caráter, desenvolvida no caráter de sua positividade, só é possível na história, horizonte no qual as criações artísticas determinaram-se como produtos espirituais a exprimir as mais altas concepções de um povo. Desse modo, sendo a arte criação, a estética, na condição de sua

\footnotetext{
${ }^{389}$ Id., WM, I, p. 265.

${ }^{390}$ Quando se trata de identificar o real sentido da obra de arte, sua compreensão apresenta-se como uma reconstrução a partir de sua referência original, uma tentativa de reconhecimento que tem como ponto de partida o momento de sua concepção original em que sua composição é organizada. Para Schleiermacher, diz Gadamer, "o ato da compreensão é a realização re-construtiva de uma produção. Tem de nos tornar conscientes de algumas coisas que, ao produtor original, podem ter ficado inconscientes" (Id., ibid., p. 299).

${ }^{391}$ Para Gadamer, essa compreensão hermenêutica de garantir o significado da obra de arte mediante a reconstrução do original justificou, outrora, uma tendência de deslocar as obras de arte mantidas em museu para o lugar originário de sua determinação (id., ibid., p. 266).
} 
específica reflexão, supõe a constituição efetiva de seu objeto desdobrado em toda sua dimensão histórica. Também nesse sentido, pensar o objeto estético é exercitar a capacidade de distanciamento da arte para poder refletir sobre ela filosoficamente. Comparado com Schleiermacher, pensar o verdadeiro significado da arte a partir da consciência de uma perda diante da tradição tem um sentido bastante diferente. Isso se torna claro mediante a leitura gadameriana da clássica passagem da Fenomenologia do espírito (Phänomenologie des Geistes), de 1807, na qual Hegel refere-se ao evanescimento da vida antiga e sua correspondente "religião da arte", bem como a forma específica mediante a qual ainda podemos compreender a arte do passado.

\begin{abstract}
"Falta à obra das musas a força do espírito, [esse espírito] para o qual, do esmagamento dos deuses e dos homens, surgira a certeza de si mesmo. São agora o que são para nós: belos frutos caídos da árvore, que um destino amigo nos estende, como uma donzela que oferece frutos. Não há a vida efetiva do seu ser-aí, nem a árvore que os carregou, nem a terra e os elementos que constituíam sua substância, nem o clima que constituía sua determinação, nem a mudança das estações que dominavam o processo do seu vir-a-ser. Assim, com as obras daquela arte, o destino nos entrega não o seu mundo, nem a primavera da vida ética, em que elas amadureceram e floresceram, mas somente a recordação velada dessa efetividade" ${ }^{, 392}$.
\end{abstract}

Nessa afirmação hegeliana o que orienta o comportamento de gerações posteriores com relação à arte não se constitui como um empenho hermenêutico com vistas à reconstrução das condições sob as quais uma obra do passado cumpria a originalidade de sua determinação. A exigência de uma conservação histórica torna-se vã na medida em que cabe à atualidade posterior de sua criação não a consciência de sua perfeita verdade; a essa experiência com a obra de arte resta apenas limpar

“[...] esses frutos de algumas gotas de chuva ou grãos de areia. Em lugar dos elementos interiores da efetividade e do ético que os rodeia, engendra e vivifica, constrói uma prolixa armação dos elementos mortos de sua existência externa, da linguagem, do histórico, etc., não para viver dentro deles, mas somente para representá-los dentro de si [...] o espírito do destino que nos oferecem essas obras de arte é mais que a vida ética e a efetividade daquele povo, pois é a recordação [er-inneren] do espírito ainda exteriorizado nelas”393.

Enquanto "frutos arrancados da árvore", as obras passadas, por mais que sejam reconduzidas a seu contexto histórico original, não constituem mais para nós um acontecimento que nos permita uma relação vital com elas, mas apenas uma relação imaginativa. É o espírito absoluto em sua auto-imposição histórica que domina e sustenta a tarefa hermenêutica. Diferentemente de o saber histórico abrir, todavia, caminho para a reconstituição do que foi perdido originalmente na tradição, a essência do espírito histórico em vez de prender-se a uma restituição o do passado, constitui-se "[...] na mediação do pensamento com a vida atual". O

\footnotetext{
${ }^{392}$ G.W.F. HEGEL, Fenomenologia do espirito, p. 185.

${ }^{393}$ Id., ibid.
} 
espírito do destino que aquelas obras de arte nos oferecem é a própria autoconsciência do saber absoluto que, sob a forma de lembrança e de um modo superior, abrange a verdade da arte. A metáfora dos "frutos arrancados" e então oferecidos também significa o acento negativo, como assinala Gadamer, que o argumento da conservação histórica representa para o idealismo hegeliano com vistas a garantir o verdadeiro significado da arte. O procedimento hermenêutico de pensar com respeito ao passado converte-se em um comportamento histórico da imaginação, e, dessa forma, a experiência da arte restringe-se a uma experiência de recordação. Como bem se vê, diz Gadamer: Hegel não contesta com isso a legitimidade de adotar um tal comportamento histórico ante a arte do passado. "O que faz é expressar o princípio da investigação da história da arte, que, como todo comportamento histórico, não é aos olhos de Hegel, mais que um labor externo" ${ }^{\text {,394. }}$

Se a tarefa da hermenêutica segundo Gadamer inclui a arte como esfera de investigação, reivindicando para ela o status de verdade, essa experiência da arte ao se manifestar na história pressupõe aquela mediação de pensamento com a vida atual, essencial à concepção de espírito histórico hegeliano. Inerente àquilo que Gadamer qualifica como princípio de investigação da história da arte, a partir do qual Hegel reflete sobre nossa relação histórica com a arte do passado, reside um princípio nuclear para a compreensão hermenêutica do caráter de atualidade da arte enquanto exposição de seu sentido e de sua verdade. Trata-se da tão controvertida tese do "fim da arte" ${ }^{\$ 95}$ proferida pela estética hegeliana e com a qual Gadamer dialoga, afirmando-a em seu caráter paradigmático para a compreensão da identidade da arte moderna.

\subsection{O caráter paradigmático da tese hegeliana do fim da arte}

Desde o início a legitimidade da abordagem hermenêutica do fenômeno artístico foi garantida pela necessidade de estender o fenômeno da compreensão ao mundo histórico-

\footnotetext{
${ }^{394}$ H.-G. GADAMER, WM, I, p. 268.

395 É na Introdução dos Cursos de estética que Hegel formula em algumas passagens a tese do fim da arte. Diz Hegel: "Seja como for, o fato é que a arte não mais proporciona aquela satisfação das necessidades espirituais que épocas e povos do passado nela procuravam e só nela encontraram; uma associação que se mostrava intimamente associada à arte, pelo menos no tocante à religião. Os belos dias da arte grega assim como a época de ouro da Baixa Idade Média passaram". Mais adiante continua: "Em todas essas relações a arte é e permanecerá para nós, do ponto de vista de sua destinação suprema, algo do passado. Com isso, ela também perdeu para nós a autêntica verdade e vitalidade e está relegada à nossa representação, o que torna impossível que ela afirme sua antiga necessidade na realidade efetiva e que ocupe seu lugar superior" (G.W.F. HEGEL, Cursos de estética, Vol. I, p. 35).
} 
cultural vislumbrado nestas experiências de verdade. A compreensão, convém lembrar, é fundamentalmente de caráter histórico-efeitual. Desse modo, o que torna nosso universo um universo hermenêutico não é senão o modo pelo qual vivemos as experiências de nosso próprio existir, testemunhando, interpretando e compreendendo acontecimentos radicalmente novos ou que nos chegam de longe. Manifestando a linguagem em que vivemos nossa contemporaneidade um distanciamento de modelos e referenciais clássicos, a filosofia na condição de hermenêutica, como é concebida por Gadamer, parece, inevitavelmente, convocar-nos a um questionamento histórico-conceitual quando se trata da exposição de um tema. Enquanto experiência de verdade manifestada na história, a compreensão da arte, conforme anteriormente ressaltamos, remete-nos à fertilidade de um diálogo entre o antigo e o novo. Na reflexão da hermenêutica filosófica, a arte não é uma atualidade independente do tempo, mas concretização espiritual e histórica de um acontecimento, em cujo processo de transmissão confluem o presente e o passado como via de busca da verdade. Por isso, retomar o caráter de atualidade da arte significa também inserir-se em pressuposições filosóficas já solidificadas na história do pensamento e cujo destaque se faz sobressair nas reflexões contemporâneas sobre arte e pensamento;dentre elas, o idealismo estético hegeliano.

Como pode ser observado no cerne do pensamento estético contemporâneo, a retomada de algumas diretivas da estética hegeliana ${ }^{396}$, e mais precisamente aquilo que ficou conhecido como "doutrina do caráter passado da arte", ou mesmo a "tese sobre o fim da arte", parece ter atingido consagração e se tornado um referencial paradigmático no horizonte de suas interpretações . Seja interpretando-a segundo os princípios lógico-dialéticos de seu sistema, seja a partir de uma tentativa de distanciamento da idéia de totalidade, Hegel parece dialogar bem quando se trata de discutir as evidências e o destino da experiência artística moderna ${ }^{397}$.

Levando em conta essa argumentação, chegamos à compreensão de que a arte nos impõe a tarefa de saber ouvi-la naquilo que ela predispõe-se a falar, para além das reações subjetivas que desencadeia em nós, e sem que sua experiência de sentido possa tomada como um signo recordativo ou de remissão a algo, representando assim algo que não é. Seja nas determinações da arte moderna, a partir do século XIX, ou passadas, a arte exige de nós um traço especialmente comunicativo; aquilo que nela se encontra é sempre o que ela tem a dizer. Aquilo que se move e de alguma forma nos agita parece, entretanto, impor-se bem mais à

\footnotetext{
396 "Os Cursos sobre estética pertencem às obras de Hegel que mais profundamente determinaram o pensamento dos séculos posteriores" (H.-G. GADAMER, Herança e futuro da Europa, p. 51).

397 "Por arte moderna mencionamos aqui as manifestações artísticas que emergem como conseqüência da quebra de uma tradição uniforme representada em última onda pelo século XIX” (Id., Aksch., p. 32).
} 
nossa atenção do que o que simplesmente permanece inalterado. Como então apreender essa verdade que nos fala e que quer ser ouvida, essa linguagem que, estando aí, quer dizer-nos algo? De outra forma, como então entender essas mudanças acarretadas pelas radicais transformações do fenômeno artístico, a partir do século XIX, senão tomando como referência a formulação teórica do "fim da arte" sustentada pela estética hegeliana? Diretiva essa que apresenta sua notoriedade, seja quando nos predispomos a pensar o horizonte de mudanças das configurações artísticas em suas diversas tendências, seja para sedimentar o caráter eminentemente histórico da estética filosófica, seja para suscitar, diante das novas produções artísticas, um questionamento quanto à re-significação de seu sentido e de sua verdade.

O remeter-se gadameriano à tese do fim da arte, no entanto, adverte quanto à importância de esta idéia não significar " [...] simplesmente a reação de uma geração à mudança das coisas e do gosto [...] como se ela fosse o fim do bom gosto e da verdadeira arte"398. Conforme veremos, acompanhando-se a leitura gadameriana, trata-se de um fim cujo significado torna legítimo o testemunho da dúvida, da suspeita, da ruptura de tendências a germinar um novo crescimento, a instaurar novas configurações e novos desafios ao pensamento. Faz-se relevante indagarmos de que modo Gadamer reconhece o valor dessa sentença declarada pela teoria do caráter passado da arte? Como se dá a especificidade desse seu diálogo com o idealismo hegeliano?

Para quem busca discutir, no percurso de suas especulações hermenêuticas, a atualidade do belo e da arte, as reflexões estéticas hegelianas acerca do caráter espiritual da arte como um círculo e estágio de verdade constituem um esteio intelectual fundamental. A pretensão hermenêutica de um diálogo que aqui se determina consolida-se, todavia, tão-somente com um Hegel fragmentário, sob a exigência de um distanciamento crítico do rigor lógico de seu sistema. Embora possamos questionar a validade de considerar as reflexões do pensamento hegeliano, sejam aquelas voltadas à estética ou mesmo a qualquer outra área do conhecimento, à revelia de sua idéia de sistema, do rigor lógico de sua dialética do pensamento, o fato é que assim, e somente assim, parece ter adquirido esta formulação estética hegeliana um valor mais atual de projeção, convertendo-se em um prenúncio da situação da arte moderna no século XX, em suas mais visíveis metamorfoses e mais diferentes linguagens.

Hegel, ao analisar as possibilidades dialéticas de realização efetiva da Idéia no seio na finitude sensível, propositalmente nos incita a pensar a relação entre arte e verdade, seja do

\footnotetext{
${ }^{398}$ H.-G. GADAMER, Herança e futuro da Europa, p. 49.
} 
ponto de vista lógico-dialético, seja do ponto de vista de sua démarche histórica. Alerta-nos quanto à sentença de sua dissolução (Auflösung) não apenas do ponto de vista lógicoconceitual - a arte é então superada por formas mais plenas de verdade: a religião e a filosofia ${ }^{399}$-, mas também como tal prognóstico decorre do desdobramento histórico-dialético do espírito (Geist), tendo em vista a cifra das condições favoráveis ou não do tempo a testemunhar sua negação (Aufhebung). Desse modo, assim como as circunstâncias de prosperidade para a idealização do real estariam nas "latências poéticas" de uma cultura, numa situação adversa, inseridas em condições tão-somente prosaicas, regidas pela racionalização da linguagem e representação do pensamento, as obras de arte já não mais se apresentam sob a forma plena de uma apresentação (Darstellung) da Idéia. Tomá-las nesse sentido só se faz possível pelo empenho da memória, mediante o artifício da lembrança, remetendo a algo do passado.

Quando Hegel afirma que "o estado de coisa de nossa época não é mais favorável à arte ${ }^{400}$, isso significa, ou melhor, isso decorre da circunstância de relações que as produções artísticas estabeleciam com a cultura da época, em meados do século XIX. Não mais expressando aquele destino de plenitude vital inerente à arte clássica, elas convertem-se em um objeto de representação, rendendo-se ao simples exame daquilo que é refletido. Tornamse produtos de uma cultura marcada pelo utilitarismo, dominada pela regra, pela lei, pelos conceitos e determinações abstratas. O que fora autêntico e verdadeiro na arte clássica, mostrando perfeito equilíbrio entre conteúdo e forma, matéria e espírito, agora agoniza: tornou-se relegado a sua representação.

Conforme interpreta Gadamer, o propósito hegeliano de sua reflexão não visa a atestar o fim da tradição plástica (imagética) cristã-ocidental, mas sim evidenciar que a arte nos tempos modernos já não mais se deixa compreender por si mesma, assim como o fizera no mundo grego, ao representar o divino por si mesmo, seja pelas esculturas, seja enquanto presença no templo. Com o cristianismo, essa configuração plástica que o divino assume sob a forma da figura humana já não se torna mais possível. A compreensão de Deus no além - a intelecção da presença de Deus - já não permite à arte expressá-lo adequadamente em sua verdade ${ }^{401}$. A idéia desse Deus supramundano do cristianismo determina-se nas chamadas artes românticas,

\footnotetext{
399 "Se, segundo Hegel, o saber e a ciência são o que faz da arte algo do passado, a ciência não é, porém, para ele, o progresso impressionante das ciências experimentais que relacionamos com o lema do positivismo; é antes a síntese compreensiva de todo o nosso saber, que, num último sentido, enquanto ciência do conceito, enquanto filosofia, ultrapassou até mesmo a tarefa da arte e representa uma forma mais elevada de consciência intelectual" (id., ibid., p. 50-1.)

${ }^{400}$ G.W.F. HEGEL, Cursos de estética.p.35

${ }^{401}$ H.-G. GADAMER, Aksch., p. 34.
} 
como na pintura e na música, mas apenas como rememoração e celebração da memória do divino.

Embora Gadamer afirme que a teoria do caráter passado da arte não traga como intenção ser uma crítica da arte de seu tempo, isso não significa que sua validade limite-se à perspectiva de pensar a arte unicamente como coisa do passado. Não se trata de fixar-se apenas no caráter nostálgico de uma arte que atingiu a plenitude de sua beleza enquanto apresentação sensível da verdade. Como afirma o próprio Hegel em uma outra passagem: "No conjunto, já desde muito cedo o pensamento voltou-se contra a arte como representação sensível do divino [...] No progresso da formação cultural surge em geral em cada povo uma época em que a arte aponta para além de si mesma"402. O pensamento sobre sua evolução e suas mudanças decorrentes das transformações histórico-culturais inerentes a elas parece encontrar nessa consideração hegeliana a sua justificativa ${ }^{403}$. Por isso, ressalta Efie Poulain, Gadamer, ao discutir o tema do fim da arte, tomando-o em seu caráter paradigmático, parece também fazê-lo a propósito de um tema ainda maior, qual seja, a legitimação da arte contemporânea. Portanto, o que parece fundamental na tese hegeliana para a realização da tarefa hermenêutica de pensar a experiência ou o acontecimento da arte é o caráter de ruptura com a tradição que naquela formulação parece estar bem evidente.

Desenvolvendo-se, por um lado, o diálogo de Gadamer com Hegel sob a forma de um ajuste de contas no sentido de que, para a hermenêutica, a experiência da arte não pode mais ser analisada do ponto de vista metafísico do Absoluto, por outro lado, tanto Gadamer quanto Hegel estão inseridos numa tarefa de pensar que assume como prioridade o fato de os produtos artísticos espirituais serem considerados a partir de sua mediação histórica e de sua experiência de verdade. Se a reflexão hermenêutica gadameriana acerca do caráter de "atualidade do belo" vislumbra pensar e justificar as manifestações da arte moderna para além de uma ingênua relação de estranhamento, Hegel, ao formular a tese do "fim da arte", também busca pensar a verdade da arte de seu tempo, justificando historicamente o trânsito dialético de suas mudanças e ressaltando que é só com base na compreensão do caráter de ruptura com a tradição que podemos compreender melhor a função que a arte desempenha no universo da vida humana.

\footnotetext{
${ }^{402}$ G.W.F. HEGEL, Cursos de estética, Vol. 1, p. 117.

${ }^{403}$ Também está expresso na tese de Hegel que "[...] desde o século XIX os artistas já começaram a sentir-se mais ou menos desarraigados em uma sociedade que estava se industrializando e comercializando, de modo que o artista encontrou confirmada em seu próprio destino boêmio a velha reputação de vagabundos de antigos trovadores" (H.-G. GADAMER, Aksch., p. 36). Sem que subsista mais a evidência de comunicação entre estes e os homens, os artistas, diz Gadamer, criam para si uma consciência messiânica, aparecendo como os novos redentores (Immerman). O fazer artístico torna-se proporcional a essa sua nova pretensão.
} 
O que torna paradigmático o caráter passado da arte para a reflexão hermenêutica é o fato de que, enquanto uma pressuposição filosófica do século XIX, essa reflexão insere-nos na problemática de sua atualidade, exigindo da atividade do pensar o estabelecimento de uma relação entre o que outrora fora a arte e o que ela é no presente. Na afirmação de Argullol, em sua introdução à obra $A$ atualidade do belo, submeter à tarefa da reflexão a indagação sobre a atualidade da arte só se torna possível a partir de uma "ponte ontológica entre a tradição artística e a arte moderna, entre a arte do passado e a arte moderna"; não apenas como opostos, mas visualizando na tradição o impulso criador para o moderno.

Reconhecer as produções artísticas em sua declaração duradoura dentro de nosso próprio mundo implica, inevitavelmente, submetermo-nos à alteridade de uma cultura antiga. Do ponto de vista hermenêutico, é na intimidade com a tradição que o artista moderno apresenta a audácia de suas produções, e o espectador, na qualidade de quem admira e experiencia, mantém-se cercado entre passado e presente.

No processo de sua fruição, a arte dos tempos modernos, além de suscitar juízos sobre suas configurações, parece instigar-nos oferecendo às nossas expectativas o desafio de suas novas expressões, às vezes enigmáticas e estranhas, às vezes curiosas e sugestivas .

Uma das ilustrações apresentadas por Gadamer no tocante a essa questão é o impacto ocasionado pelo movimento cubista, quando instaura uma quebra na tradição ao sugerir uma modificação quanto à referência objetiva de um objeto qualquer, convidando-nos a olhar uma pintura sem que nos submetamos passivamente a sua percepção. "Para ver, há que se levar em consideração uma atividade muito especial; sintetizar pessoalmente as diversas facetas, cujos traços aparecem na tela numa elaboração própria; e logo talvez sejamos arrebatados e enriquecidos por uma profunda harmonia e correção da obra, igual ao que ocorria antigamente sem problema algum sobre a base de um conteúdo comum do quadro" ${ }^{\text {"404 }}$.

Entre outros elementos de análise - embora não seja nosso propósito desenvolvê-lo em sua completude nesse momento -, a tarefa necessária de uma justificativa da arte, a partir do fim da Antiguidade, constitui um aspecto fundamental da busca do significado hermenêutico do caráter passado da arte hegeliano. Ver na arte a presença do passado significa assinalar que, embora sua essência pertença ao passado, seu florescimento futuro não é interrompido. De qualquer forma, há, segundo Gadamer, uma novidade decisiva no que diz respeito à

\footnotetext{
${ }^{404}$ H.-G. GADAMER, Aksch., p. 39.
} 
evolução da arte, qual seja, o "fim da tradição humanística cristã",405, cujo significado aponta para o esvaziamento do mito, daquilo que de tal modo se narra, que ninguém pode duvidar de sua verdade; daquilo que em sua evidência a todos congrega. O que é evidente chega ao fim. Ainda nesse sentido, ao determinar o caráter pretérito da arte, vendo na arte a presença do passado, Hegel confere ao universo da arte a determinação de sua autonomia e consciência. Enquanto presença do passado e consciência dessa alteridade, a arte também adquire consciência de sua contemporaneidade.

O que chega ao fim e morre é a possibilidade de um tipo de produção artística: o ideal como forma de apresentação, encenação do divino no sensível. O fim, nesse sentido, equivale a um processo, ou mesmo um percurso, histórico de dissoluções, correspondentes aos estados gerais do mundo, constitutivos da história da cultura ocidental. Se esse caráter do fim da arte equivale algumas vezes a um sentido de morte, é precisamente enquanto negação que não só traz consigo a possibilidade de ruptura, como também do nascimento de um novo tempo de criação. Desse modo, o que se impõe como tarefa do pensamento hermenêutico é a seguinte questão: como justificar a experiência da verdade da arte diante de um agente social novo, inerente às pretensões da arte moderna?

Logo, pensar a problemática de sua verdade tomando como ponto de partida a tese do fim da arte de Hegel significa inserir-se num outro tipo de fundamentação, cujo questionamento encontra em Heidegger uma formulação expressa:

\footnotetext{
"Não nos podemos esquivar à sentença que Hegel pronuncia nestas proposições por meio da constatação de que, desde que a Estética de Hegel foi apresentada pela última vez, no semestre de inverno de 1828-9, na Universidade de Berlim, vimos surgir muitas obras de arte e correntes artísticas novas. Hegel nunca quis negar essa possibilidade. A questão, porém, mantém-se: é a arte ainda um modo essencial e necessário, como acontece à verdade que é decisiva para nosso ser-aí histórico, ou já não é?" ${ }^{\text {} 406}$.
}

É precisamente a repercussão desse questionamento que nos encaminha à diretiva hermenêutico-fenomenológica sobre a relação entre arte e verdade. Se, conforme diz Hegel, a arte tem por missão tornar presente de modo concreto aquilo que possui um conteúdo rico, aquilo que é pleno de conteúdo, mediante o horizonte contextual que marca a crise da arte romântica, ela ultrapassa a si mesma e determina-se essencialmente a partir do humano. "Todo ser humano, em cada atividade, seja artística, política, religiosa ou científica, é um filho de sua época e tem a tarefa de elaborar um conteúdo essencial [...], assim também

\footnotetext{
${ }^{405}$ Id., Herança e futuro da Europa, p. 52.

${ }^{406}$ M. HEIDEGGER, A origem da obra de arte, p. 87.
} 
permanece como determinação da arte que ela encontre a expressão artisticamente adequada para o espírito de um povo" ${ }^{, 407}$.

Assim, é do ponto de vista da reflexão sobre a finitude humana, tendo em vista os fundamentos de uma ontologia fundamental, que a reflexão sobre a arte remete-nos ao desenvolvimento de sua nova orientação. Nesse sentido, reconsiderar a questão da arte como experiência de verdade dentro dessa nova diretiva hermenêutica só se torna possível mediante uma interpretação crítica dos conceitos fundamentais da metafísica, em busca de uma resposta sobre o sentido do ser.

Pensar a temática da verdade da arte a partir de Heidegger implica, por conseguinte, a própria crise da metafísica, a destruição das ontologias do ente, da ontologia tradicional. Crise ou fim da metafísica que corresponde ao fim de um tipo de racionalidade. Crise de uma razão (Vernunft) eterna que insiste em sempre inscrever-se universalmente. O pensamento filosófico sobre a arte que a partir de então emerge sem apelo a soluções metafísicas tem sua viabilidade em uma "hermenêutica da facticidade". Assumindo-se que a arte seja tomada em função do sentido do ser, isto se dá também porque sua reflexão constitui-se em um pretexto de crítica à noção e ao valor da verdade. Enquanto uma forma de aparição do ser, a arte é um modo de ser da verdade como desocultação, revelação que instaura algo de novo na existência que se dá na facticidade do mundo. Portanto, uma indicação essencial de crítica à verdade metafísica. Se a verdade (aletheia) manifesta-se na arte é porque, sob a forma de acontecimento, se faz obra (ins Werk gesetzt), ajustando-se à finitude por seu caráter temporal.

Nesse raciocínio, se o desenvolvimento da relação de identidade de arte e verdade fora concebido como uma apresentação (Darstellung) histórica do Infinito manifestando-se e efetivando-se no espírito de um povo (Volksgeist), a essência de sua significação é denunciada sob a forma de um questionamento dessa verdade do ente. O conteúdo metafísico do subjetivismo estético tornou-se estranho à verdadeira essência da arte, que traz ao pensamento um novo pensar.

Heidegger movimenta-se, de alguma forma, dentro da questão hegeliana sobre a relação entre arte e verdade, exatamente por perceber o reconhecimento de perda, por parte da arte, de verdade autêntica; o que, conseqüentemente, demarcaria o rompimento da arte com o absoluto, sua base metafísica. É, todavia, no interior de seu próprio pensamento que Hegel fornece-nos elementos que nos permitem pensar para além de seu próprio tempo, sinalizando,

${ }^{407}$ G.W.F. HEGEL, Cursos de estética, Vol. 2, p. 338. 
nas diretivas de sua reflexão estética, a própria legitimidade da crise da metafísica, condição imprescindível para a reapresentação da problemática de arte e verdade.

Ora, a possibilidade de retomar a questão da arte como experiência verdadeira condiciona-se ao significado e ressonância da crise da metafísica como fora desenvolvida por Heidegger, e isto se dá desta maneira porque agora uma filosofia da arte não pode mais render-se a um olhar dirigido à infinitude das idéias, ao mais além, "met'ekêina", ao divino "tò thêion".

É a partir dessa compreensão heideggeriana que Gadamer busca legitimar a experiência da arte como esfera de reivindicação de verdade. Daí que sua reflexão hermenêutica sobre essa questão reivindique e assegure a possibilidade necessária de um caminho de regresso à tradição, mediante um caminho de revisitação e questionamento de conceitos sobre o universo estético, sobre o ser e sobre a verdade. O que parece renovar-se nessa reflexão é sua articulação necessária ao fenômeno da compreensão e sua interpretação como experiência (Erfahrung). Enquanto experiência de verdade, é também experiência de linguagem como lugar de mediação. Por isso, nosso encontro com a arte é o encontro com a verdade; o encontro com a experiência de pertencermos, nós e a obra, àquele horizonte representado pela linguagem, de onde parte seu próprio acontecimento. Investigar, para Gadamer, seu verdadeiro ser é questioná-la enquanto um tornar-se experiência; o que só é possível resgatando-se a experiência em obra que vem a nosso encontro. Pensá-la em sua verdade significa investigá-la em seu modo de ser, em seu caráter ontológico, conforme mostramos anteriormente. É do ponto de vista de uma análise antropológica e, portanto, do horizonte da finitude humana que o modo de ser da arte assume na essência de sua representação seu pôrse como verdade.

Ora, pensar o fenômeno hermenêutico a partir de seu fundamento mais determinante, qual seja, a finitude da experiência histórica, só se faz possível sob os rastros da linguagem; é só com base nela que se estrutura nossa própria experiência de mundo e a experiência hermenêutica. Apenas a partir da linguagem e, conseqüentemente, por sua referência ao todo dos entes, pode realizar-se a mediação da experiência de finitude histórica do ser humano consigo mesmo e com o mundo. Isso se dá pela unidade da palavra que tanto nos é dita, como dirigimos aos outros. Seu caráter dialético, enquanto um falar articulado, é puro desdobramento e, ao mesmo tempo, revela uma dimensão interna. Faz ressoar o âmbito ao qual pertence, a acepção de mundo de onde emerge. Como diz Gadamer: "[...] cada palavra, como acontecer de seu momento, faz que aí esteja também o não dito, ao qual se refere, 
respondendo e indicando [...] Todo falar humano é finito no sentido de que, nele, jaz uma infinitude de sentido a ser desenvolvida e interpretada ${ } 408$.

Por fim, além da relação hermenêutica com o mundo da ciência moderna e o mundo da racionalidade técnica, parece necessário reconhecer, que além de uma refutação, a proposta da hermenêutica filosófica de Gadamer é uma conseqüência da própria modernidade. No âmbito das discussões que problematizam a questão da verdade da arte, eis o que também justifica a tentativa de um diálogo, cujo fundamento é a proximidade na diferença, a partir de autores como Hegel e Heidegger, constelações nucleares para a estruturação e giro que a filosofia hermenêutica empreende no pensamento contemporâneo sobre o fenômeno da arte.

${ }^{408}$ H-G. GADAMER, WM,I., p. 462. 


\section{CONCLUSÃO}

$\mathrm{O}$ que confere particularidade especial à relação entre estética e hermenêutica no pensamento de Gadamer? Independentemente das discussões mais específicas desenvolvidas no tocante à experiência da arte como um modo de ser, ou mesmo um movimento de vir-àrepresentação, essa questão tem como antecedente aquilo que nos remete ao cartesianismo moderno.

A idéia de método sobre a qual se baseia a ciência moderna assume no pensamento de René Descartes um desdobramento que lhe o caráter de referencial e indubitável. A construção do saber deve ser examinada metodicamente e ter como alicerce fundamentos certos. Em nossa qualidade de seres de experiência, a compreensão de uma "tabula rasa" do saber moderno é então regida por um método, cujo fundamento e modelo são a evidência do cogito, do eu penso, essa certeza inquebrantável. Daí se deduzem todas as proposições da ciência, seguindo o exemplo da geometria. A ciência já não pode mais voltar-se para o saber construído a partir de pré-juízos e da tradição, uma vez que ela não pode mais basear-se em idéias preconcebidas e na aceitação de afirmações de uma autoridade histórica da tradição, afirmações que se afiguram agora meramente subjetivas. Mas, se o cartesianismo prescreve o âmbito de rigor metodológico a partir do qual a ciência assegura sua convicção como o lugar da verdade, o pensamento de Hans-Georg Gadamer, pode-se afirmar, é, antes de tudo, o seu contraponto.

É sob um impulso crítico de contraposição ao saber moderno que a obra filosófica de Gadamer busca sua densidade enquanto proposta de uma reformulação hermenêutica. Opondo-se a essa concepção do saber moderno baseado em um método, sua análise deixa-se orientar por uma dúvida crescente com respeito à ampliação dessa idéia universal de método. Faz-se necessário mostrar, sob os fundamentos de uma hermenêutica, que a compreensão de método da ciência não se constitui na única via de acesso à verdade. O que Gadamer de fato questiona não é a vinculação entre método e verdade, pois para ele é bastante óbvia a compreensão do método como um caminho viável para a verdade, sendo esta uma afirmação que dispensa objeções ${ }^{409}$. Convém ratificar que seu propósito não constitui um esforço para invalidar a idéia de um método como elemento de investigação e de compreensão dos fenômenos, mas fundamentalmente seu objetivo é assinalar seus limites, sob o risco de que

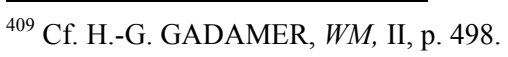


sua pretensão de monopólio e de referencial possa impossibitar-nos ou mesmo falsear outras experiências de verdade. Verdade e método, sob propósito de fornecer-nos os elementos fundamentais de uma hermenêutica filosófica, parece manter-se firme em sua tarefa: sob o rigor da crítica ao subjetivismo moderno e a demarcação do que é possível conhecer como verdade, recuperar as experiências de verdade, conferindo a elas legitimidade filosófica. Se o questionamento dos pressupostos fundamentais dessa teoria do método estabelece limites a uma busca de um saber que absolutamente se mantém claro e certo, ele ao mesmo tempo submete ao tribunal da crítica - num dizer kantiano - o paradigma de uma evidência reflexiva que se pensa a si mesma.

Reconhecer a amplitude do saber humano, priorizando a diversidade de experiências que perfazem a relação entre homem e mundo, significa, para Gadamer, contrariar essa pretensão. É verdade que, diante dessa postura reflexiva, Gadamer insere-se no debate vigente no século XIX entre as ciências naturais e ciências humanas, ratificando a necessidade de que essas últimas reconquistem sua legitimação como ciência, mas esse pronunciamento, embora ampliado em suas análises, não parece constituir seu objetivo maior. O esclarecimento urgente sobre a autoconcepção das ciências humanas, sob o viés da recuperação dos conceitos humanistas, tendo em vista o conseqüente processo de sua estetização, constitui, de fato, uma análise diferenciada sobre o saber humano; é esse o problema que precisa ser retomado como questão de fundo. A ontologia fundamental de Martin Heidegger, inevitavelmente, é que lhe oferece as bases para isso.

Mas podemos perguntar-nos: o que garante a uma análise ontológica da compreensão, ou mesmo do saber, a capacidade de ampliar a legitimação das experiências de verdade?

Em primeiro lugar, a evidência de que a compreensão é uma experiência de finitude, essencialmente enraizada na noção de um Dasein histórico que é abertura, negatividade e permanente projeto. Vista agora sob o caráter de uma circularidade, a compreensão humana amplia-se, acrescenta-se enquanto movimento próprio de interpretações mediante o qual a interpretação confere autonomia à alteridade. $\mathrm{O}$ saber humano a partir de então segue na dependência dos pré-juízos (Vorurteile) e da tradição, cuja autoridade é assegurada por uma concepção de história baseada em uma fusão de horizontes, a Wirkungsgeschichte. A história, em seu caráter de vigilância, segue como o grande imperativo do saber humano; nela, enquanto movimento de interpelação, de mediação, tanto somos reconduzidos ao conhecimento histórico de nossa formação, como nos mantemos no encontro diante daquilo que esta aí e de alguma forma nos interpela. 
O título da obra Verdade e método, inicialmente pensado como Entender e acontecer (Verstehen und Geschehen), recorda, ainda que vagamente, o da obra de Goethe Poesia e verdade (Dichtung und Wahrheit). Verdade e método resulta em decepção para leitores que tinham expectativa de encontrar no acesso ao pensamento aí presente muitas informações sobre a natureza do "método" e da "verdade". Seguindo a tradição de Schleiermacher, o interesse de Gadamer é tomar como ponto de partida e referência fundamental uma análise filosófica sobre o compreender. O compreender como uma experiência que nos sustenta e da qual nos nutrimos, de modo que junto aos outros possamos compartilhar nossas experiências. O fenômeno da compreensão e a análise filosófica sobre a experiência constituem, na verdade, o grande fio condutor que confere, no horizonte de seus desdobramentos, especificidade a Verdade e método.

O procedimento de buscar a experiência de verdade em outros âmbitos também apresenta sua particularidade na medida em que se trata aqui de um procedimento hermenêutico desenvolvido sob uma vigilância histórico-efeitual; daí a reabilitação da tradição retórica, de uma filosofia prática e até de uma hermenêutica jurídica e teológica. $\mathrm{O}$ diferencial dessa busca é, no entanto, seu encontro marcado com o testemunho da arte. Ao identificar na arte uma experiência de verdade, Gadamer não apenas avança enquanto escolha fundamentada de um ponto de partida. O que ele enxerga e pretende a partir desse testemunho é, além de recuperar uma noção de verdade que se estenda à pluralidadedas experiências humanas, pensá-la como via de aplicação, demonstração dos fundamentos da hermenêutica filosófica, devidamente desenvolvidos ao longo de Verdade e método.

Isso também justifica a afirmação de que analisar a dimensão da experiência estética no horizonte hermenêutico de Gadamer significa identificar as etapas de um procedimento que é paradigmático. Pensá-la, primeiramente como procedimento de crítica, destruição e recuperação e, posteriormente, como desenvolvimento de uma reflexão sobre seu modo de ser, como experiência de finitude essencialmente determinadas pela noção de consciência histórica e pela cifra da linguagem. Por isso, não basta perguntar por aquilo que justifica a experiência estética ou mesmo a experiência da arte como reflexão inicial de Verdade $e$ método, mas como se desenvolve o raciocínio que a sustenta tanto no capítulo inicial quanto ao longo da estrutura da obra. A esse propósito uma leitura mais analítica desta obra, sobretudo, em seu primeiro momento, nos remete a tentativa ou mesmo a um cuidado quando no tratamento dos termos "estética" (aisthesis) e "arte"(Kunst), usados algumas vezes quase que indistintamente Eis aí o que também lhe confere um caráter paradigmático. . 
Independentemente da articulação que se possa fazer entre esses dois termos do ponto de vista de suas significações terminológicas, precisamos a respeito ter claro o seguinte: a expressão "estética" é utilizada tanto como caracterização da consciência - consciência estética -, como sob o estatuto epistemológico cunhado nos tempos modernos a partir de Baumgarten e com dedobramentos na filosofia de Kant e no neokantismo. A referência à estética representa para Gadamer não apenas uma referência histórico-conceitual, mas de modo significativo o procedimento crítico e necessário de sua "destruição". A crítica aos pilares da filosofia moderna enquanto crítica da subjetividade, inevitavelmente se realiza sob a forma de uma crítica ao fenômeno da estetização dos conceitos humanísticos, bem como à consciência estética, sobretudo a partir de Kant. Conseqüentemente, recuperar a pergunta pela verdade da arte significa destruir em primeiro lugar as construções de pensamento que impossibilitaram reconhecê-la como experiência autônoma de verdade e confinaram-na como expressão de genialidade e vivência de prazer. Eis um elemento que fundamenta a especificidade das reflexões estéticas a partir do pensamento hermenêutico de Gadamer. O que de forma bem objetivao aparece como crítica à concepção da estética moderna enquanto condição de possibilidade de repensarmos a arte como experiência hermenêutica da verdade tem como foco principal a proposta de uma resignificação do conceito de verdade. Para tanto a reflexão sobre a estética e a arte sobressaem-se como aplicação prática da crítica ao paradigma da sujetividade e, conseqüentemente aos desígnios exclusivistas da ciência moderna em seu acesso à verdade.

A retomada da indagação pela verdade da arte tem como condição de possibilidade o questionamento da formação estética e do estreitamento da concepção de "consciência estética" que daí decorre. Inserindo-se nessa argumentação talvez possamos afirmar que o desenvolvimento do conceito de "aisthesis", na conquista de seu estatuto epistemológico, ao longo do pensamento moderno, acarretou um "prejuízo" significativo à relação arte, pensamento e verdade ${ }^{410}$. Prejuízo aqui também entendido como Vorurteil, pré-condição inevitável para a compreensão - no sentido ontológico-heideggeriano - que nos distancia do esquecimento e nos projeta à abertura de novos questionamentos.

A relação estética e hermenêutica, no modo como ela se desenvolve na filosofia de Gadamer, não nos oferece, portanto, a formulação sólida de uma estética, nem tampouco de uma teoria sobre as artes. Entretanto afirmar a especificidade dessas reflexões como um

\footnotetext{
${ }^{410}$ A possibilidade dessa hipótese não é indiferente a uma das máximas da estética hegeliana: a arte como manifestação sensível da idéia no horizonte do sensível define-se como momento de verdade.
} 
simples momento de desvio pode também parecer, um tanto quanto insuficiente, para alguém que reconhece na importância de pensar sobre a experiência misteriosa da arte um desempenho necessário para as ciências humanas ${ }^{411}$. Não se pode desconsiderar, no entanto, que na fase de seu trabalho posterior a Verdade e método manifesta grande empenho em desenvolver categorias e argumentos no tocante à retomada da questão da verdade da arte. Nessa fase, ressalta tanto o seu caráter declarativo, como a aplicação teórica do suas reflexões estéticas através de ensaios sobre as mais diferentes peças artísticas, sejam arquitetônicas, literárias ou mesmo voltada às artes plásticas.

Gadamer está bastante próximo de Heidegger, em cujo pensamento a estética e a arte estão situadas em um contexto não apenas histórico, mas de questionamento sobre toda a metafísica ocidental. Quando também se fala em "destruição estética", vale ressaltar a completa mudança de posição tradicional tanto do artista, quanto do contemplador da obra. Vislumbrada no caráter de sua materialidade, de sua "coisidade", a obra passa então a exigir um espaço e abertura, alterando-se a função ordenadora da forma sobre a matéria. Eis o que se pode compreender não só com base em $A$ origem da obra de arte, como também a partir de $O$ tempo da imagem do mundo (Die Zeit des Weltbildes), de 1938. Esse último texto de Heidegger associa à época moderna, a época do desenvolvimento da técnica e da ciência, a marca de entrada da arte no horizonte da estética, cujo resultado foi a submissão da arte a uma compreensão prática e estética. Num tempo em que o homem é conduzido à cultura sob a exigência do cumprimento de valores mais elevados, em que a técnica sobressai como uma transformação autônoma da prática, e em cujo horizonte o vazio instala-se como decorrência da "fuga dos deuses" $"$, também se evidencia "o processo da arte deslocar-se para o âmbito da estética. Isto significa que a obra de arte torna-se âmbito da vivência, e, conseqüentemente, a arte vale como expressão da vida do homem" ${ }^{413}$. Ora, não se trata de considerar apenas a subordinação das artes a um regime normativo da estética enquanto disciplina filosófica, ou mesmo de desencadear um relacionamento da esfera do artístico com a esfera do sensível, a aesthesis, através da beleza e do prazer usufruídos pelos homens, pois, como sabemos já desde os gregos, a beleza era um termo aplicado nas diferenciações de seus tipos, seja às coisas e objetos fabricados, seja à alma e às virtudes. $\mathrm{O}$ grande problema identificado por Heidegger é que a estética, em seu regime disciplinar e normativo, faz realçar o fenômeno de

\footnotetext{
${ }^{411}$ C.f. H-G. GADAMER, "Retrospectiva dialógica à obra reunida e sua história da efetuação", in: C.S. ALMEIDA; H-G. FLICKEINGER; L. RHODEN, Hermenêutica filosófica; Nas trilhas de Hans-georg Gadamer, p.205.

${ }^{412}$ Cf. M. HEIDEGGER, "O tempo da imagem no mundo", in: Caminhos de floresta, p. 97-8.

${ }^{413}$ Id., ibid., p. 97.
} 
uma soberana subjetivação, enraizada tanto na produção da obra de arte quanto na apreciação do belo. A origem da obra é a criação do artista, e seu destino é a fruição subjetiva do seu contemplador. Eis aí a grande conseqüência da "entrada da arte no horizonte da estética". Como diz Benedito Nunes a esse propósito: “A estetização, finalmente, foi o predomínio da variante do ente, que ascendeu com o cogito cartesiano, trazendo a ascendência do sujeito metafísico pensante (substância, res cogitans), que também implica ascendência da sensibilidade" ${ }^{414}$.

A crítica à consciência estética desenvolvida por Gadamer desde o começo de Verdade e método é, portanto, a crítica à estetização e subjetivação como tentativa de resgate do espaço e abertura da obra, abstraídos pela consciência estética e que nos remetem, como contraponto, ao resgate de sua historicidade. Da destruição da estética segue-se a ressignificação do fenômeno da arte como tentativa de tornar inválida sua abstração de temporalidade e historicidade, asseguradas pela noção de consciência estética. Faz-se necessário reatar o laço rompido da obra com seu mundo. Por detrás de uma perda sempre se encontram os germes de uma recuperação. Neste sentido, a noção de "destruição da estética" que se apresenta no quadro reflexivo de Gadamer - a partir de Heidegger - corresponde a um procedimento que se realiza sob a forma de um movimento retrospectivo, perfazendo seu retorno e os efeitos de sua própria formação. Compreender é considerar os elementos de formação de um determinado conhecimento, daí seu caráter eminentemente histórico. Isso, todavia, não se dá simplesmente sob a forma de apenas enumerar momentos e reflexões sobre determinada experiência acerca de produções de pensamento, justapondo-as ou mesmo descrevendo-as historicamente. Bem mais que isso, trata-se de considerar esses elementos de formação do conhecimento sob o rigor crítico de seus efeitos e da geração de suas influências. O sentido de destruição tem aqui o sentido de uma "desconstrução" de seu fundamento, permitindo ao originário uma nova revelação. As experiências estéticas sempre constituíram uma experiência de mundo, e as configurações artísticas sempre se mantiveram como um testemunho da espiritualidade de um povo; reconsiderá-las na razão de ser de suas representações (Darstellungen) é apenas o que está proposto sob o rigor crítico dessa destruição.

A proposta de "destruição da estética" inaugura, assim, um nova pergunta pela arte, cuja essência remete-nos à sua recuperação como acontecimento de verdade. A recuperação de seu laço originário com o mundo, no entanto, está radicalizada em sua natureza histórica e

${ }^{414}$ B. NUNES, Hermenêutica e poesia: O pensamento poético, p. 110. 
lingüística. É preciso admitir que muitas vezes Gadamer parece-nos repetitivo, ao reconsiderar constantemente o fenômeno da compreensão, mas isso se dá - pensando-se aqui na exclusividade de nossa temática - porque sua acepção ontológica é imprescindível para assegurar essa abertura reflexiva que se impõe como decorrência da crítica e da destruição da estética.

Num contexto em que a ciência torna-se legítima enquanto exploração organizada da natureza e sua pesquisa está voltada para a organização de meios e recursos, a verdade científica parece assegurar ao indivíduo cada vez mais seu lugar central no mundo, explorando-o sistematicamente e orientando-se pela busca de suas certezas. Cabe às artes dar a usufruir o prazer, seja público ou privado, circulando enquanto bem cultural na condição de mercadoria. Mesmo tornadas objetos, porém, as obras dão-nos o que pensar, ao especularmos sobre seu ser. Ainda que diante de sua força de impressão, que em muito se impõe, obras como Édipo rei e Antígona, expressões maiúsculas da tragédia grega, , o templo grego em suas ruínas, os quadros de Van Gogh, entre outras manifestações artísticas, parecem estar destituídas de seu próprio mundo, mesmo mantidas as suas interpretações e a conservação que lhe correspondem. Por mais que desafiem o próprio tempo e venham, de quando em quando, a nosso encontro, elas não são mais o que foram. Elas apresentam-se hoje a nós, é verdade, mas não podemos esquecer que isso se dá pela força da tradição ou mesmo por uma complexa operação de conservação visando muitas vezes diretamente seu comércio, ou atividades lucrativas em torno delas.

Desse modo, articulando-se a essa constatação, a compreensão do Dasein como abertura e projeto, historicidade, a compreensão gadameriana da Wirkungsgeschichte é decisiva para a retomada da pergunta pela arte e para sua definição como presença declarativa, como Auslegung. É a partir desse princípio que se torna possível ultrapassar a experiência da arte como relação entre sujeito e objeto. A arte enquanto experiência que vem a nosso encontro e nos interpela não se rende a uma consciência que se limita a um prazer casual, subjetivo, vivencial. Sua compreensão só se realiza mediante uma fusão de horizontes, uma mediação que busca sentido no acordo oriundo entre a memória da tradição e a presença da situação e a temporalidade presente. É isso precisamente que perfaz o sentido da arte como declaração. Naquilo que a obra vem-à-fala, ela constitui-se em pura travessia e reconhecimento de que sua experiência habita nos efeitos de uma história. O fenômeno da arte é um fenômeno hermenêutico porque também nos permite uma leitura do passado a partir dos seus efeitos (Wirkung) no presente. 
$\mathrm{Na}$ verdade, observa-se em Gadamer uma superestima da tradição, o que lhe rendeu várias críticas. É com base nessa compreensão que a idéia atuante e eficaz da Wirkungsgeschichte torna-se possível em seu caráter de efeitos da tradição. O clássico, diz Gadamer,

“[...] é o que revoga a diferença entre as mutações do tempo e sua oscilação do gosto [...] é a consciência de permanência, do significado imperecível, independente de qualquer circunstância temporal [...] é uma espécie de presença intemporal [eine Arte zeitloser Gegenwart] que concede contemporaneidade a cada um dos presentes" ${ }^{415}$.

Em uma entrevista a Carsten Dutt, perguntado sobre o caráter de atemporalidade do clássico, a propósito de um pretenso classicismo subjacente ao primeiro capítulo e Verdade e método, conforme crítica de seus leitores, Gadamer diz-nos que de modo algum podemos negar a distância histórica que nos separa das obras clássicas, bem como a possibilidade de questões histórico-cognitivas as quais elas nos remetem. Acrescenta:

"Sem dúvida isso mesmo pode dizer-se de nossa consciência histórica desenvolvida, do sentimento histórico [...] com o qual nos acercamos hoje das obras artísticas [...] a Nona sinfonia de Beethoven significa para nossa compreensão mais que um sistema de tarefas reconstrutivas e históricas [...] não se trata de um testemunho de algo, testemunho que tenhamos de interpretar primeiro: é a obra mesma que nos interpela [...] como se fôssemos seus primeiros ouvintes. Escutamos a música de Beethoven. E já ao escutá-la há uma autêntica participação que se expressa no conceito e adesão [...] a esta música" ${ }^{116}$.

Aqui talvez caiba um questionamento a Gadamer no sentido de perguntar em que medida, embora nos pareça óbvia a idéia da história como continuidade, podemos compreendê-la atualmente mediante seu culto à tradição? Nesse sentido, até que ponto a explicitação gadameriana da Wirkungsgeschichte asseguraria ao intérprete não cair nas armadilhas de uma arbitrariedade subjetiva?

A importância que o fator da tradição tem para o presente equivale a seu status enquanto um papel fundamental que desempenha em toda compreensão. Para Gadamer, parece estar muito claro que aquele que interpreta está efetivamente consciente da diferença entre a tradição e seu horizonte temporal presente, porém, sua compreensão inclui necessariamente uma mediação de ambos os horizontes. A compreensão é, pois, sempre a aquisição de um novo horizonte histórico, que daí emerge. Ora, isso nos remete ao caráter de atualidade da arte, no modo com que Gadamer o desenvolveu em $A$ atualidade do belo. Nesse texto verifica-se uma demonstração da hermenêutica filosófica enquanto uma hermenêutica da aplicação; a experiência da arte como experiência da finitude sob a vigilância da história. Não basta afirmar que a compreensão dá-se enquanto fusão de horizontes sob a forma de um

\footnotetext{
${ }^{415}$ H.-G. GADAMER, $W M$, I, p. 272.

${ }^{416}$ C. DUTT, En conversación con Hans-Georg Gadamer, p. 72.
} 
diálogo entre o passado e o moderno. Embora muitas vezes o fenômeno da arte moderna cause estranhamento, isso se dá porque também somos conduzidos pela unilateralidade de uma compreensão do clássico como gerador de modelos. É verdade que a tradição interpelanos, mas isto se dá também no sentido de conscientizar-nos sobre a diferença que se enraíza em nosso presente. A proposta de Gadamer de entender a atualidade da arte por meio de um retorno à tradição do pensamento significa que a experiência da arte é uma experiência ontológica de desocultação, cuja abertura é atualizada no tempo, de acordo com sua lingüisticidade. Aquilo que se põe como verdade nas formas diferenciadas da arte moderna, nas tendências de seus movimentos, é seu próprio vir-à-fala como experiência lúdica de celebração, cuja referência maior parece ser a linguagem. A linguagem da arte traduz a sua verdade, o modo pelo qual dialoga com a tradição e executa a sua tendência, o seu pronunciamento.

A recuperação da arte como experiência de verdade segue o caminho de recuperação da idéia de experiência hermenêutica da finitude humana trazida pela tradição hermenêuticofenomenológica. Por isso, a arte é declaração de verdade enquanto celebração e declaração de finitude. A verdade aqui se constitui em um jogo, um entrelace ontológico entre o oculto e o desvelado. Então, para Gadamer, a retomada da arte só se realiza em função do ser, porque ser, em sua concepção, é aquilo que ultrapassa o pensamento da subjetividade. Nesse sentido, a arte é sua recordação e quer agora ser pensada para além dos limites da subjetividade. A temporalidade de sua presença tem a marca da festa, cuja celebração revela-a como continuidade de nossa existência e como esfera de interação e confronto. O que a torna uma reivindicação de verdade é que, em sua experiência, a verdade não apresenta mais a identidade da certeza, e tampouco se restringe à unificação normativa do conhecimento teórico e científico da natureza.

Por fim, o que confere a essa reflexão sobre a arte o estatuto de um pensamento sobre a verdade é sua natureza enquanto experiência hermenêutica, uma experiência de abertura e memória, de desconstrução e recuperação da finitude humana sob o horizonte universal da linguagem, essa nossa condição radical como seres humanos, determinados que somos pela pergunta, pela interpretação e pela busca de respostas. "Com isso a consciência hermenêutica adquire uma extensão tão abrangente, que ultrapassa a da consciência estética. A estética deve subordinar-se à hermenêutica",417.

\footnotetext{
$\overline{{ }^{417} \text { H.-G. GADAMER, WM, I, p. } 170 .}$
} 
Mediante o exposto torna-se claro que a proposta ontológico-hermenêutica de Gadamer, nem mesmo se nos restringirmos ao âmbito significativo do capítulo inicial não cai num esteticismo; bem pelo contrário o prolongamento de suas análises mostram-se muito mais como uma atitude crítica a este. Todavia, sobre essa questão merece ainda uma consideração especial a formulação crítica dirigida a Gadamer de que o seu esteticismo culminaria numa concepção estética da verdade no final de Verdade e Método. De acordo com o princípio de Wirkungsgeschichte a dimensão ontológica do questionamento hermenêutico desenvolvido por Gadamer identifica na retomada de um conceito metafísico antigo, na fecundidade do seu significado uma grande contribuição a tarefa crítica de sua hermenêutica.

Trata-se do conceito do belo, visto em seus traços semânticos comuns entre a tradição grega - kalon - e a língua alemã - Schön -. Gadamer observa que o conceito Kalon constituise como categoria ôntica superior, na medida em que ela integra “[...] tudo o que não faz parte das necessidades da vida, mas que diz respeito ao modo de viver, ao eu zen, tudo aquilo que os entendiam sob o termo Paidéia. São coisas belas aquelas cujo valor é evidente por si mesmo [...] são excelentes (vorzüglich) por si mesmas (di'hauto haireton), não em virtude de outras coisas, como ocorre com o útil" ${ }^{418}$. No alemão, todavia a palavra "belo" embora também denote uma expressão de grandeza, ela também remete ao admirável (Ansehlich), cuja significação aponta para o conveniente e para o âmbito dos costumes. Assim é junto a filosofia platônica que Gadamer, identificando uma relação entre a idéia de belo e do bem, vai justificar a inseparabilidade destas. Mas se em Platão as determinações ontológicas do belo são universais, são também ligadas à medida e à proporção, cuja demonstração paradigmática estaria na matemática. O objetivo do hermeneuta é nos advertir que o retorno à Platão, em sua metafísica do belo, é a via de reformulação do questionamento hermenêutico sobreo racionalismo estético. A relação entre as idéias do belo e do bem em Platão, segundo Gadamer não deixa, de forma alguma, escapar o predomínio do belo. Essencialmente o que o caracteriza é a abertura, o seu aparecer, por isso ele tem a sua própria luminosidade. "A beleza tem o modo de ser da luz"419. A aletheia, desde Platão constitui-se a essência do belo, manifesta-se, representa-se como imagem. Mas em que medida a metafísica da luz ampliaria a relação arte e verdade? Ao que nos parece trata-se apenas de buscar nessa concepção metafísica antiga um reforço de sustentação para compreendermos que uma experiência autêntica, inclusive a da arte, sempre é aquela que estabelece um encontro com a verdade

\footnotetext{
${ }^{418}$ Id., ibid., p.482.

${ }^{419}$ id.ibid., p.486.
} 
(aletheia). Ao aproximar a significação do belo com a verdade, seu intento parece ser muito mais uma ampliação crítica da noção de estética moderna, em benefício da experiência da arte como experiência da vida

Sobre a posssibilidade de que isso nos remeteria a uma recaída metafísica, nos diz Vattimo: "Se se quer evitar esta recaída [...] a hermenêutica tem que tornar explícita sua dimensão ontológica, quer dizer, a idéia heideggeriana de um destino do ser que se articula como a concatenação, das aberturas, dos sistemas de metáforas que tornam possível e qualificam nossa experiência do mundo" ${ }^{, 420}$

A questão, todavia, se mantém aberta, sem que ninguém possa nos ofrecer uma última palavra.

${ }^{420}$ G.VATTIMO., A reconstrução da racionalidade, in: G.VATTIMO (comp), hermenêutica da racionalidade. p.157. 


\section{REFERÊNCIAS BIBLIOGRÁFICAS}

\section{Obras de Hans-Georg Gadamer}

GADAMER, H.-G. Wahrheit und Metod: Grundzüge einer philosophischen Hermeneutik. Gesammelte Werke 1, Hermeneutik I. 1975, $4^{\text {a }}$ ed.

. Wahrheit und Metod: Grundzüge einer philosophischen Hermeneutik, Gesammelte Werke 1, Hermeneutik I. Tübingen: J.C.B. Mohr (Paul Siebeck), 1990, $6^{\text {a ed. }}$ . Wahrheit und Metod: Ergänzungen, Register. Gesammelte Werke 2, Hermeneutik II. Tübingen: J.C.B. Mohr (Paul Siebeck), 1986. . Ästhetik und Poetik I: Kunst als Aussage. Gesammelte Werke 8. Tübingen: J.C.B. Mohr (Paul Siebeck), 1993. . L'art de comprendre. Écrit II: Herméneutique et champ de l'expérience humaine. Paris: Aubier, 1991. . Le problème de la conscience historique. Paris: Seuil, 1996. . Herança e futuro da Europa. Trad. de A. Hall. Lisboa: Edições 70, 1998. . Elogio da teoria. Trad. de J.T. Proença. Lisboa: Edições 70, 2001. . Arte y verdad de la palavra. Trad. De J.F.Z García e F. Oncina. Barcelona:

Paidós: 1993 .El Giro Hermenêutico. Trad. de A. Parada. Madrid: Catedra, 2001 . El inicio de la sabiduría. Trad. de A.G. Ramos. Barcelona: Paidós, 2001. . El problema de la conciencia histórica. Trad. de A.D. Moratalla. Madri:

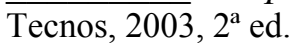
. Estética y hermenéutica. Trad. de A.G. Ramos. Madrid: Tecnos, 1998, $2^{\mathrm{a}}$ ed. . Hermenéutica de la modernidad. Conversaciones com Silvio Vietta. Trad. de L.

Elizaicín-Arrarás. Madri: Trotta, 2004 . La actualidad de lo bello. Trad. de A.G. Ramos. Barcelona: Paidós, 1977. . La dialéctica de Hegel. Trad. de M. Garrido. Madri: Catedra, 1988, $3^{\mathrm{a}}$ ed. . Los caminos de Heidegger. Trad. de A.A. Pilári. Barcelona: Herder, 2003, 2ª ed. . Verdad y método, Vol. II. Salamanca, Sígueme, 1993. . “A imagem emudecida”. In: Gávea, nº 06, 1998. 
. A razão na época da ciência. Trad. de A. Dias. Rio de Janeiro: Tempo

Brasileiro, 1983.

. O problema da consciência histórica. Trad. de P.C.D. Estrada. Rio de Janeiro:

Editora Fundação Getúlio Vargas, 1998.

Verdade e método: Traços fundamentais de uma hermenêutica filosófica. Trad.

de F.P. Meurer. Petrópolis: Vozes, 1997.

. Verdade e método: Complementos e índice. Trad. de E.P. Giachini. Petrópolis:

Vozes, 2002.

\section{Obras de autores clássicos, modernos e contemporâneos}

ALMEIDA, C.L. Hermenêutica e dialética: Dos estudos platônicos ao encontro com Hegel. Tese de Doutorado. Porto Alegre: EDIPUCRS, 2000.

ALMEIDA, C.L.; FLICKINGER, H.G. \& ROHDEN, L. Hermenêutica filosófica: Nas trilhas de Hans-Geog Gadamer. Porto Alegre: EDIPUCRS, 2000.

ARISTÓTELES. Poética. Trad. de E. de Souza. Porto Alegre: Globo, 1966.

BAUMGARTEN, A.G. Estética: A lógica da arte e do poema. Trad. de M. Medeiros.

Petrópolis: Vozes, 1993.

BAY, T.A.-Á. El lenguaje en el primer Heidegger. México: Fondo de Cultura Económica, 1998.

BLEICHER, J. Hermenêutica contemporânea. Trad. de M.G. Segurado. Lisboa: Edições 70, 1992.

CASSIRER, E. A filosofia do Iluminismo. Trad. de Á. Cabral. Campinas: Editora da Unicamp, 1994, $2^{\mathrm{a}}$ ed.

CORETH, E. Questões fundamentais de hermenêutica. São Paulo: EPU/Edusp, 1973.

DASTUR, F. Esthétique et heméneutique. La critique de la conscience esthétique chez

Gadamer. Phénoménologie et esthétique. Paris: Encre Marine, 1998.

DENIAU, G. Gadamer. Col. Philo-Philosophes. Paris: Elipses, 2004.

DILTHEY, W. Introducción a las ciencias del espíritu: Ensayo de una fundamentación del estudio de la sociedad y de la historia. Trad. de J. Marías. Madrid, 1956. . Teoria das concepções do mundo. Trad. de A. Morão. Lisboa: Edições 70, 1992.

DUBOIS, C. Heidegger: Introdução a uma leitura. Trad. de B.B. Oliveira. Rio de Janeiro: Zahar, 2004. 
DUTT, C. En conversación com Hans-Georg Gadamer: Hermenéutica - estética - filosofia práctica. Trad. de T.R. Barco. Madri: Tecnos, 1998.

FERRARIS, M. Historia de la hermenéutica. Trad. de J.P. de Tudela. Madri: Akal, 1998.

FERRY, L. Homo aestheticus. Trad. de E.M. de M. Sousa. São Paulo: Ensaio, 1994.

FRUCHON, P. L'herméneutique de Gadamer. Paris: Éditions du Cerf, 1994.

GAOS, J. Introducción a El ser y el tiempo de Martin Heidegger. México: Fondo de Cultura Económica, 1996, $3^{\text {a }}$ ed.

GARAGALZA, L. Introducción a la hermenéutica contemporánea. Barcelona: Anthropos, 2002.

GRONDIN, J. L'horizon herméneutique de la pensée contemporaine. Paris: Vrin, 1993. . Der Sinn für Hermeneutik. Darmstadt: Wissenschaftliche Buchgesellschaft, 1994. . Introdução à hermenêutica filosófica. Trad. de B. Dischinger. São Leopoldo: Editora Unisinos, 1999. . Hans-Georg Gadamer: Uma biografia. Trad. de A. Pilári \& R. Bernet.

Barcelona: Herder, 2000, $2^{\mathrm{a}}$ ed. . Introducción a Gadamer. Trad. de C.R. Garrido. Barcelona: Herder, 2003. . Von Heidegger zu Gadamer. Darmstadt: Wissenchaftliche Buchgesellschaft, 2001.

HABERMAS, J. et al. "El ser que puede ser comprendido es lenguaje". Homenaje a HansGeorg Gadamer. Madri: Síntesis, 2001. Dialética e Hermenêtica. Trad. de A.LM. Valls. Porto Alegre: LPM, 1987.

HEGEL, G.W.F. Fenomenologia do Espírito, Vol. 1. Trad. de P. Menezes. Petrópolis: Vozes, 1992. . Enciclopédia das ciências filosóficas em epitome, vols. 1 e 3. Trad. de A. Morão. Lisboa: Edições 70, 1992b. . Cursos de estética, Vol. 1. Trad. de M.A. Werle. Revis. técnica de M. Seligmann-Silva. Consult. de V. Knoll \& O. Tolle. São Paulo: Edusp, 1999. . Cursos de estética, Vol. 2. Trad. de M.A. Werle \& O. Tolle. Consult. de V. Knoll. São Paulo: Edusp, 2000.

HEIDEGGER, M. El ser y el tiempo. Trad. de J. Gaos. México: Fondo de Cultura Económica, $1971,2^{\mathrm{a}}$ ed. . Heidegger. Col. Os Pensadores. Trad. de E. Stein. São Paulo; Abril Cultural, 1979. 

. A origem da obra de arte. Trad. de M. da C. Costa. Lisboa: Edições 70, 1991. • “O conceito de tempo". Trad. de M.A. Werle. In: Cadernos de Tradução, nº 2, 1997.

. Caminhos de floresta. Trad. de I. Borges-Duarte. Lisboa: Fundação Calouste Gulbenkian, 1998.

HEKMAN, S.J. Hermenêutica e sociologia do conhecimento. Trad. de L.M. Bernardo. Lisboa: Edições 70, 1990.

HUIZINGA, J. Homo ludens. Trad. de J.P. Monteiro. São Paulo: Perspectiva, 2004, $5^{\mathrm{a}}$ ed.

KANT, I. Crítica da faculdade do juízo. Trad. de V. Rohden \& A. Marques. Rio de Janeiro: Forense Universitária, 1993.

. Kritik der reinen Vernunft. Werk in sechs Bänden, B. 2. Darmstadt:

Wissenschaftliche Buchgesellschaft, 1998.

LEONARD, A. Métaphysique. Louvain: Éditions du SIC/Institute Superieur de Philosophie, s./d.

LIMA, L.C. Teoria da literatura em suas fontes. Rio de Janeiro: Francisco Alves, 1983.

MACDOWELL, J.A. A gênese da ontologia fundamental de M. Heidegger. São Paulo:

Loyola, 1993.

MORATALLA, A.D. “De Aristóteles a Gadamer: La relevancia ética de la ontología hermenéutica”. In: Cuadernos Salmantinos de Filosofía. Vol. XVII, 1990.

. "Hermenéutica y ciencias sociales: La acogida conflictiva de Verdady método”. In: Cuadernos Salmantinos de Filosofía, Vol. XVIII, 1991.

NUNES, B. “A morte da arte em Hegel”. In: DUARTE, R. (org.). Morte da arte hoje. Anais. Belo Horizonte. Laboratório de Estética/Fafich, 1993. . Hermenêutica e poesia. Org. de M.J. Campos. Belo Horizonte: Editora

UFMG, 1999.

OLIVEIRA, M. A. Reviravolta lingüistico-pragmática na filosofia contemporânea. São Paulo: Loyola, 1996.

PEREIRA, M.B. “O século da hermenêutica filosófica”. In: Revista Filosófica de Coimbra, nº 19, 2001a. • “A crítica do nazismo na hermenêutica filosófica de H.-G. Gadamer". In: Revista Filosófica de Coimbra, $\mathrm{n}^{\mathrm{o}}$ 20, 2001b.

PESSOA, Fernando (org). Seminários Internacionais: Arte no Pensamento. Vitória: Museu Vale do Rio Doce, 2006. 
PORTOCARRERO. O preconceito em H.-G. Gadamer: Sentido e uma reabilitação. Lisboa: Fundação Calouste Gulbenkian, 1995.

REVISTA PORTUGUESA DE FILOSOFIA. "A idade hermenêutica da filosofia: Hans-Georg Gadamer", Vol. 56, fasc. 3-4, jul./dez. de 2000.

RICEUR, P. Interpretação e ideologias. Trad. de H. Japiassu. Rio de Janeiro: Francisco

Alves, 1998, $3^{\text {a }}$ ed.

ROHDEN, L. Hermenêutica filosófica. São Leopoldo: Editora Unisinos, 2003.

SCHILLER, F. A educação estética do homem. Trad. de R. Schwarz \& M. Suzuki. São Paulo: Iluminuras, 2002, $4^{\mathrm{a}}$ ed.

SCHLEIERMACHER, F.D.E. Hermenêutica. Arte e técnica da interpretação. Trad. de C.R. Braida. Petrópolis: Vozes, 1999.

SILVA, F.L. e. "Subjetividade e juízo". In: Discurso, 19, 1992.

STEIN, E. Aproximações sobre hermenêutica. Porto Alegre: EDIPUCRS, 1996. . A caminho de uma fundamentação pós-metafisica. Porto Alegre:

EDIPUCRS, 1997.

Diferença e metafísica: Ensaios sobre a desconstrução. Porto Alegre:

EDIPUCRS, 2000.

VATTIMO, G. Hermenéutica y racionalidad. Trad. de S.P. Latorre. Bogotá: Norma, 1994. . O fim da modernidade. Trad. de E. Brandão. São Paulo: Martins Fontes, 1996. . Para além da interpretação. Trad. de R. Paiva. Rio de Janeiro: Tempo Brasileiro, 1999.

VIETTA, S. Hans-Georg Gadamer. Hermenéutica de la modernidad. Trad. de L. ElizaincínArrarás. Madri: Trotta, 2004.

WEINSHEIMER, J.C. Gadamer's Hermeneutics: A Reading of Truth and Method. Nova York: Yale University Press, 1985.

\section{Obras de consulta}

CAYGILL, H. Dicionário Kant. Trad. de Á. Cabral. Rio de Janeiro: Jorge Zahar, 2000.

DOSTAL, R.J. The Cambridge Companion to Gadamer. Nova York: Cambridge University Press, 2002.

INWOOD, M. Dicionário Heidegger. Trad. de L.B. de Holanda. Rio de Janeiro: Zahar, 2002. MORA, J.F. Dicionário de filosofia. Madrid: Alianza, 1982, 4ª ed. 
OSÉS, A.O. Diccionario de hermenéutica. Bilbao: Universidad de Deusto, 1997.

PETERS, F.E. Termos filosóficos gregos: Um léxico histórico. Trad. de B.R. Barbosa. Lisboa: Fundação Calouste Gulbenkian, 1977. 